
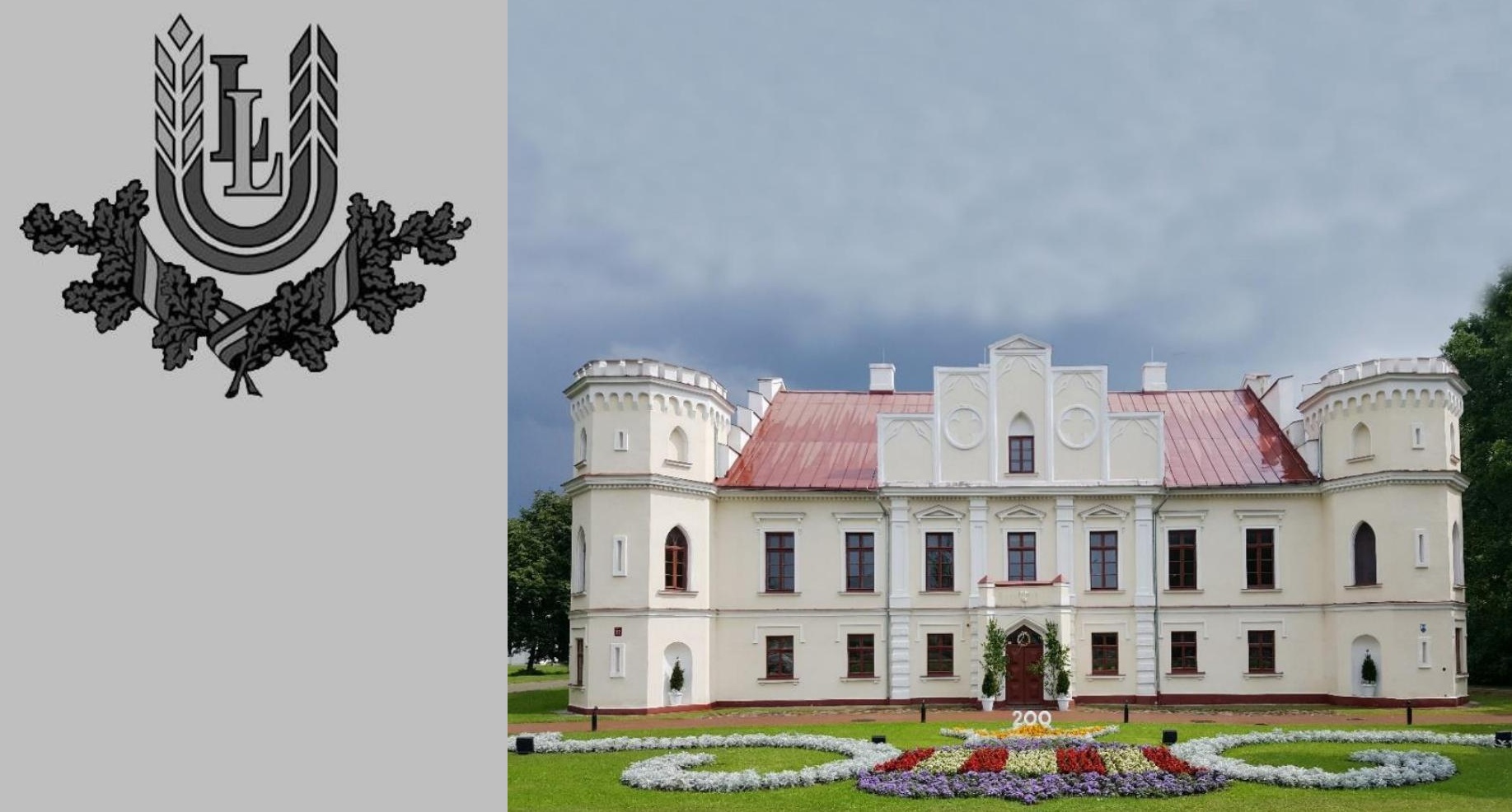

\title{
LANDSCAPE ARCHITECTURE
}

AND ART

SCIENTIFIC JOURNAL OF LATVIA UNIVERSITY OFAGRICULTURE

VOLUME 10 NUMBER 10

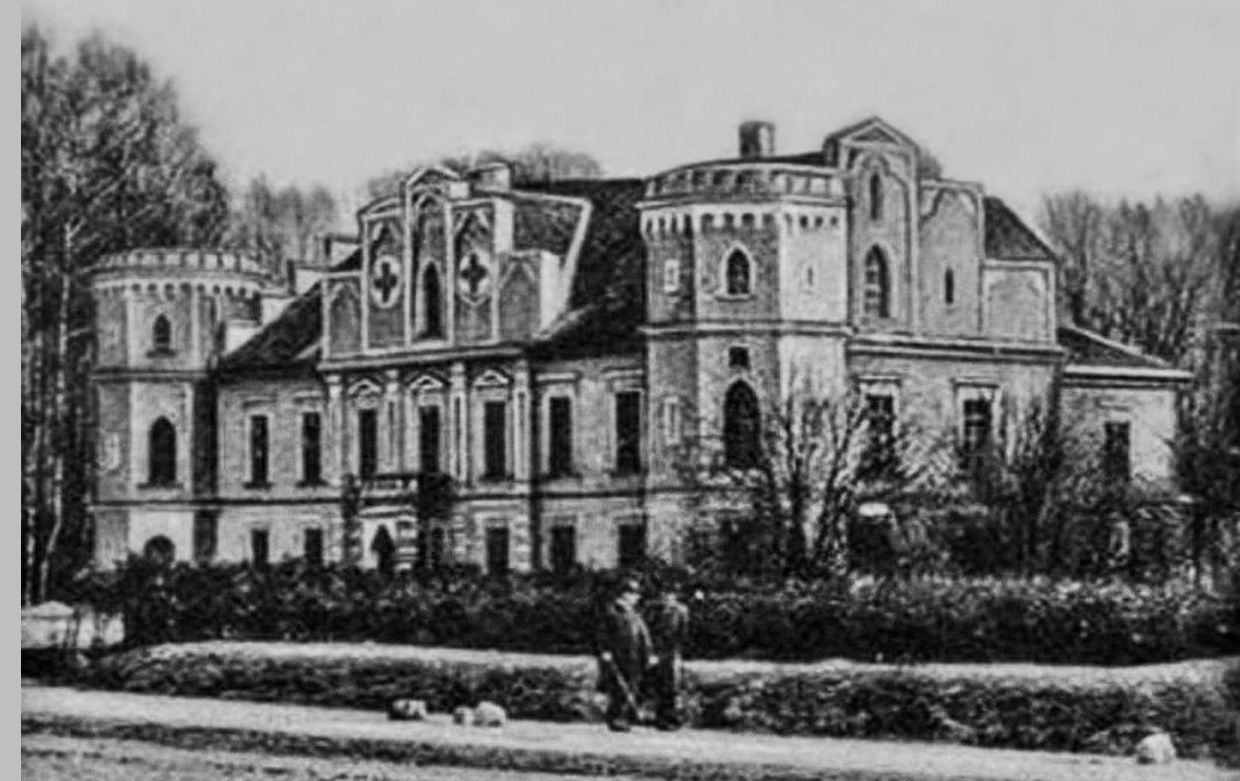

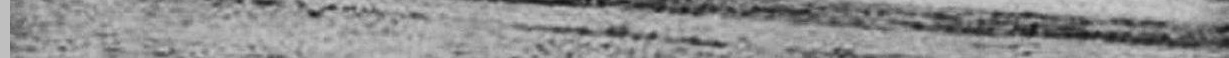

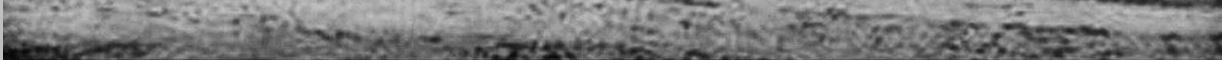


SCIENTIFIC JOURNAL OF

LATVIA UNIVERSITY OF AGRICULTURE

\section{LANDSCAPE ARCHITECTURE AND ART}

VOLUME 10

NUMBER 10 
EDITOR IN CHIEF

Aija Ziemeḷniece, Dr. arch., Professor, Latvia University of Agriculture, Jelgava, Latvia

\section{EDITORIAL BOARD}

Uǵis Bratuškins, Dr. arch., Professor, Riga Technical University, Riga, Latvia Maria Ignatieva, Dr. phil., Professor, Swedish University of Agricultural Sciences, Uppsala, Sweden

Karsten Jorgensen, Dr. scient., Professor, Norwegian University of Life Sciences, Oslo, Norway

Jānis Krastiņš, Dr. habil. arch., Professor, Riga Technical University, Riga, Latvia Juhan Maiste, Dr. art., Professor, University of Tartu, Tartu, Estonia

Eglè Navickienė, Dr. arch., Assoc. Professor, Vilnius Gediminas Technical University, Vilnius, Lithuania

Thomas Oyen, Professor, Neubrandenburg University of Applied Sciences, Neubrandenburg, Germany

Gintaras Stauskis, PhD arch., Assoc. Professor, Vilnius Gediminas Technical University, Vilnius, Lithuania

Ivars Strautmanis, Dr. habil. arch., Professor, Riga Technical University, Riga, Latvia Ojārs Spārītis, Dr. habil. art., Professor, Art Academy of Latvia, Riga, Latvia Sandra Treija, Dr. arch., Professor, Riga Technical University, Riga, Latvia Daiga Zigmunde, Dr. arch., Professor, Latvia Univeristy of Agriculture, Jelgava, Latvia

\section{SECRETARY AND LAYOUT DESIGNER}

Una Īle, Dr. arch., Latvia University of Agriculture, Jelgava, Latvia

\section{TECHNICAL TEXT EDITOR}

Renāte Čaupale, Ph.D, Latvia University of Agriculture, Jelgava, Latvia

\section{ADDRESS OF THE EDITORIAL BOARD}

Faculty of Environment and Civil Engineering Department of Landscape Architecture and Planning Latvia University of Agriculture

22 Riga street, Valdeka palace, Jelgava, Latvia, LV-3004

Phone: + 37129185575

E-mail: una.ile@1lu.lv

Abstracted and indexed*

SCOPUS (indexed since 2016); AGRIS; CABI PUBLISHING CAB ABSTRACTS; EBSCO Art Source $(*)$ - Attention! The data bases select the articles from the proceedings for including them in their data bases after individual qualitative examination. All scientific paper was reviewed by two independent reviewers. Every author is responsible for the quality and the information of his article.

Read our scientific journal in on-line:

http://llufb.llu.lv/Raksti/Landscape_Architecture_Art/

http://llufb.llu.lv/db.html?i=llu_izd_arz.html

http://www.le-notre.org/public_lni/news_show_details.php?news_id=514

https://scholar.google.lv/scholar?q=\%22Landscape+architecture+and+art\%22+latvia\&btnG=\&hl=lv\&as_sdt=0\%2C5

http://www.theeuropeanlibrary.org/tel4/record/3000059529403?classification-

cerif $=$ T000\& count $=1000 \&$ locale $=$ uk\&link-level=DIGITAL_OBJECT \& collection-id=a0163

Scientific journal cover photos: Una Īle (nowadays photo),

Jelgava History and Art Museum of Gedert Elias (historical photo)

C CATVIA UNIVERSITY OF AGRICULTURE, 2017 


\section{INTRODUCTION}

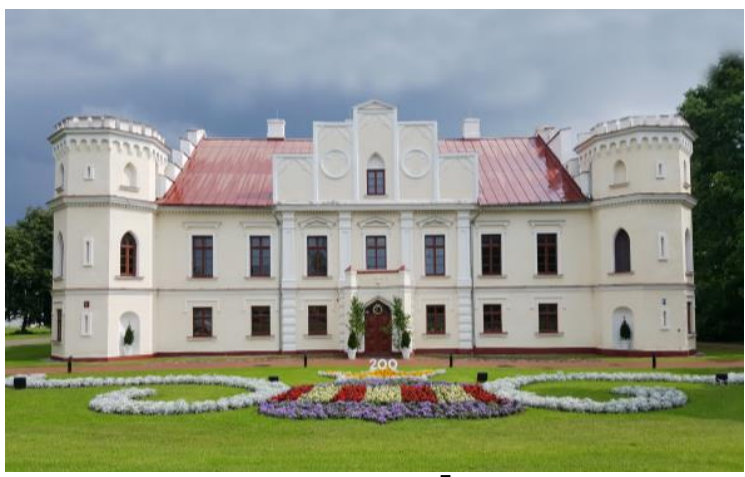

Valdeka palace [Source: U. Īles photo, 2017]

The issue of the 10th edition of the journal of the Latvian University of Agriculture comes to the readers in a remarkable time of the anniversary. Valdeka Palace, which serves as the home of studies and research for landscape architects, has historically belonged to Baron Christoph Carl von der Recke until the $20 \mathrm{~s}$ of the $20^{\text {th }}$ century. This year, in July, the $200^{\text {th }}$ anniversary of the owner of the old palace was glamorously celebrated. Another significant event for our magazine is its registration in the international scientific database SCOPUS. In the context of these remarkable events, the articles published in the anniversary issue relate to the research on the preservation of the values of the cultural and historical heritage and their synthesis with the contemporary modernist trends in architecture, art, and landscape space. Fascinating is the research on the searches of the context of the historical landscape of viticulture and the contemporary architectural and compositional form. A similar cultural and scientific landscape research has been carried out on the preservation of the historical identity of the Livonian fishermen's homesteads and the sites of the industrial heritage on the banks of the river Lielupe. Being in the cultural space of Europe, both parallels and analogies can be found in art and architecture. This applies to the research of Art Deco trends in Latvia and the Czech Republic. The searches in the architectural, artistic, and cultural currents are also relevant to the beginnings of the construction of churches in Latvia. Preserving the historic landscape space around churches in both urban and rural environments is a serious task for all the municipalities. The modernist trends of the $21^{\text {st }}$ century in art and architecture come in both public buildings and multi-storey residential areas. The diversity of construction technologies and the use of materials make it possible to achieve a high level of the avantgarde in architecture and landscape space. The spatial and compositional form, structure, and color balance are particularly important in school and kindergarten areas, developing proper emotions and perception of children.
PRIEKŠVĀRDS

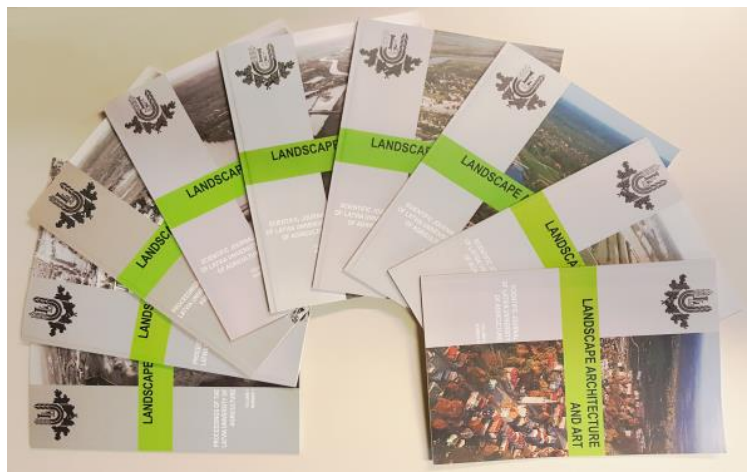

Scientific Journal Landscape Architecture and Art [Source: U. İles photo, 2017]

Latvijas Lauksaimniecības universitātes zinātniskā žurnāla 10. izdevuma numurs nāk pie lasītājiem zīmīgā jubilejas reizē. Valdekas pils, kas kalpo kā studiju un zinātnisko pētījumu mājvieta Ainavu arhitektiem, vēsturiski ir piederējusi līdz 20. gs. 20. gadiem baronam Kristofam Karlam fon der Rekem. Šogad jūlijā tika krāšņi nosvinēta vecā pils saimnieka 200 gadu jubileja. Otrs zìmīgs notikums mūsu žurnālam ir saistāms ar tā reǵistrāciju starptautiskajā zinātnisko datu bāzē SCOPUS. Šo zīmīgo notikumu kontekstā, jubilejas numurā publicētie raksti ir saistīiti ar pētījumiem kultūrvēsturisko vērtību saglabāšanā, un to sintēzi ar mūsdienu modernisma tendencēm arhitektūrā, mākslā un ainavtelpā. Saistošs ir pētījums par vēsturisko vīnkopības ainavas un modernās arhitektūras kompozicionālās formas konteksta meklējumiem. Līdz̄̄gs kultūrainaviskais pētījums ir veikts par lībiešu zvejnieku sētu un Lielupes krastu industriālā mantojuma teritoriju vēsturiskās identitātes saglabāšanu. Pastāvot Eiropas kultūrtelpā, mākslā un arhitektūrā ir atrodamas gan paralēles, gan analogijas. Tas attiecināms uz pêtījumu par Art Deco tendencēm Latvijā un Čehijā. Meklējumi arhitektūras, mākslas un kultūras strāvojumos ir attiecināmi arī uz dievnamu būvniecības pirmsākumiem Latvijā. Vēsturiskās ainavtelpas saglabāšana ap dievnamiem gan pilsêttelpā, gan lauku vidē ir nopietns uzdevums visām pašvaldībām. 21. gs. modernisma tendences mākslā un arhitektūrā ienāk gan publiska rakstura ēkās, gan daudzstāvu dzīvojamās zonās. Būvniecības tehnologíju daudzveidība un materiālu pielietojums dod iespēju sasniegt augstu avangarda līmeni arhitektūrā un ainavtelpā. Telpiski kompozicionāls formu, struktūras un kolorīta sabalansējums īpaši svarīgs ir skolu un bērnudārzu teritorijās, att̄̄stoties pareizai bērnu psihei un uztverei.

\section{Aija Ziemeḷniece \\ Editor in Chief}




\section{CONTENTS}

Olga Harea, Anna Eplényi

Viticultural Landscape Patterns - Embedding contemporary wineries

into the landscape site

Nikolay Kasyanov

The European fortifications on the coast of the Pacific Ocean

Renāte Čaupale

Parallels and Analogies in the Interwar Architecture

in Latvia and Czechoslovakia.

Una İle

Trends in Development of Public Outdoor Space, an Example of Copenhagen

Dace Ržepicka, Aija Ziemeļniece

The compositional and functional study of the Liv fishermen's homesteads

Santa Vaļivahina (Mazika)

The non-implemented vision "Karosta - Culture Port"

Aija Ziemeļniece

Transformation of the silhouette of the urban space. Jelgava example

Una Kancāne, Una Īle

Recreation Potential in Ādaži Village

Jānis Zilgalvis

Krimulda Church and the cultural and historical environment around it .72

Daiga Zigmunde, Anna Katlapa

Industrial Heritage Landscape of the Lielupe River in Latvia 81 


\title{
Viticultural Landscape Patterns - Embedding contemporary wineries into the landscape site
}

\author{
Olga Harea, Anna Eplényi PhD, Szent István University, Hungary
}

\begin{abstract}
In the recent years, the wine culture, being mostly influenced by economic conditions, undergoing some transformations and moving more into the sphere of relaxation, and entertainment. Parallel with the development of the wine culture, the wine architecture also undergoing changes - they had not only to accommodate to the production but also to represent the firm, and being the part of the new brand. Nowadays, to fit into the landscape, to preserve and express its character as well as the tradition and the mystery of wine production is the basic evaluation criteria for wine architecture.

The main focus of the research is to emphasize how to fit the architectural forms into viticultural landscapes. To carry out the study, were selected six examples of comtemporary wine arhitecture, which are located in a specially valuated and protected cultural landscape. The samples are analysed from two aspects: the context (the relevance to the landscape patterns / courtyard scale, connection with the terrain) and basic visual elements (materials, roof shape, form-imitation, view spots). The goal is to emphasize the techniques and strategies for the improvement of wine architecture and landscape, and provide an understanding about the current state of built forms and landscape design in vineyards.
\end{abstract}

Keywords: viticultural landscapes, vineyard patterns, wine architecture, vineyards

Introduction - Looking back

Viticultural landscapes are a perfect example of the most beautiful human-made landscape settings in the world. In Mediterranean and temperate climate regions, vineyards cover mountainous, hilly, coastal and floodplain areas. They represent one of the largest agro-ecosystem, and they are the most important agricultural activity in terms of environmental impact and income [1].

Vineyards have enriched the landscape since time immemorial. They give countries their characteristics and order. Their geometric patterns and colourful varieties are a magical element of expressive landscapes [2], which prove how the utilitarian organization of the land can also be aesthetically pleasing.

Ever since humans first discovered how to turn grapes into a delicious, intoxicating beverage, there have been special buildings for wine production. Although the ancient Greeks are considered to be the founders of viniculture in the Mediterranean, it was the Romans who, as well as fostering the extensive expansion of vineyards in their empire, erected purpose-built, free-standing buildings for viniculture from the first century AD onwards [3].

During the last decades, the culture of wine has been redefining itself and wineries architecture has undergone transformations that have been a consequence of this evolution. Firstly, there were Roman farming estates - villa rustica and villa urbana [3], various underground areas and cellars to provide a stable temperature for the production and storage of wine. Later, fortresses, castles, monasteries, church institutions and hospitals, palaces and chateaux were built above wine cellars, where the wine was also consumed.

A significant step in the development of winery architecture occurred mainly from the 19th century. In the wake of the Industrial Revolution, champagne and sparkling wine cellars (in Champagne), Sherry bodegas (in Andalusia) and port wine lodges (in the Douro Valley in Portugal), riding a wave of worldwide export success, stepped up their business activities. This increase in production created a need for new buildings of unprecedented dimensions [3]. Consequently, while wine estates and cellars were undergoing a structural redesign, the winemaking process and the rural character of wine-growing slowly began to change.

In the 20th century, directly after the Second World War, wine architecture in most of European wine-growing countries saw little in the way of revival. This only emerged from 1980 onwards [3]. The architecture of wine progressed rapidly and stridently, at the same time undergoing some dramatic transformations [4] - focused on a comprehensive modernization of production facilities and buildings [3] (e.g. Château Lafite Rothschild (1987), Château Pichon Longueville (1990) etc.). As a result, the new structures, in which functionality was the top priority, were massive and flashy and did not always fit harmoniously into their surroundings or regional landscape. 


\section{Contemporary Wine Architecture}

In the recent years, the wine culture, being mostly influenced by economic conditions, is experiencing again some transformations and moving more into the sphere of relaxation, and entertainment. The wine architecture has reshaped its face, losing the traditional historical and rural features to add more agricultural, business and bran-making one.

Visual considerations are becoming more vital to a winery's image and status [3]. To design new wineries or extensions was important to respect a number of standards, such as to make them appropriately blend into the landscape, respect the topography of the terrain and genius loci of the site where the structure is located, to express its character as well as the tradition and the mystery of wine production.

The architects are being challenged to rethink the winery as a bold contemporary expression of tradition and innovation, agriculture and technology, production and hospitality [5]. As a result, many new wineries and vineyards have captured the public's eye in recent years thanks to their unique functional architecture, which perfectly transmits the atmosphere of their surroundings while reflecting the tradition of the winemaker. Some of these buildings are designed to establish brand identity and excite public attention in a fiercely competitive market, others blend into the landscape or abstract the local vernacular [5]. The content of wineries has been changed, alongside the physical requirements of a winery - the fermenting cellar, wine storage area, bottle warehouse, packaging and shipping - certain of these buildings include tasting area, shop, restaurant and even accommodation. Such buildings are typically situated alone and surrounded by vineyards, and offer to wine lovers the privilege of experiencing the exceptional ambiance and landscape vineyards. Therefore, they do not serve only for collecting and producing, but also for "selling" the landscape [6].

\section{Goals and objectives}

The most important communication for architectonic development is how the countryside can be built on, now and in the future, and how a new understanding of symbiosis of nature and culture could be created [7].

The particular focus of the research is to emphasize how to fit the architectural forms into viticultural landscapes. Based on case studies the aim of this paper is to answer the following questions: What kind of techniques do the designers use to fit the building into the landscape? How does the landscape character influence the building?

The case study analysis of winery and vineyard sites provides a richer understanding about the current state of buildings and landscape design in vineyards and offers design guidance and strategies for the improvement of wine architecture and landscape.

\section{Evaluating method}

Relying on personal interpretation, we have selected six examples (new buildings and extensions), which show a complex relation to the landscape, and are award winning projects, widely published on websites, in periodicals and books. As a consequence we assumed that our projects represent top quality architecture, and at the same time they may also work as a model.

To carry out the study and get a qualitative result, we relied on written materials (designers' texts, architectural critics' reviews), photos, and layout plans from Google Maps. To dissect and observe contemporary design strategies of the case studies we examined their context: site plan - the relevance to the landscape patterns / courtyard scale; connection with the terrain: the various degree of cut and fill, sunken spaces; and basic visual elements: materials - colour / texture; roof shape / form-imitation; view spots: glass and terrace / balcony surfaces). All the schemes were shaped in "Adobe Photoshop CS6" program, using some graphical tools were marked/emphasized the particular features, such as layout of the building, entrances, patterns, landforms, etc.

\section{Discussion}

The case study buildings are situated in a specially valuated and protected cultural landscape. The Quinta Do Vallado Winery is established in Baixo Corgo wine sub-region of the Douro Valley region (a UNESCO World Heritage Cultural Landscape Site since 2001), Portugal. The Franz Keller Winery is settled in the Baden wine region, namely in the Kaiserstuhl wine district, Germany. The Antinori Winery is located in Chianti, wine district of Tuscany, Italy. F.X. Pichler Winery is located in Wachau, wine district of Lower Austria (UNESCO World Heritage site since 2000). The Swiss example, Lavaux Vinorama is established in Lavaux sub-region of Vaud wine region (a UNESCO World Heritage Cultural Landscape Site since 2007). The Ysios Winery is located in Laguardia, in the Rioja Alavesa region, Spain.

Quinta do Vallado, founded in 1716, is one of the first port houses in the Douro Valley. The wine estate, consisting of 130 ha of vineyards, lies on both banks of the Corgo River, a tributary of the Douro River. In 2003 the Quinta do Vallado Douro Reserva received its first prizes, afterwards the wine estate became one of the most highly regarded in Europe and can now look back on a number of international 


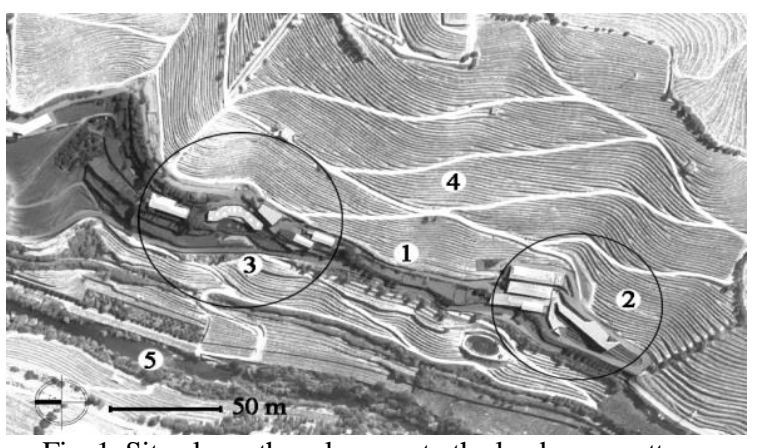

Fig. 1. Site plan - the relevance to the landscape pattern: 1. built area; 2. production zone; 3 . leisure zone; 4. terraced vineyards; 5 . Corgo River [Source: created by author, 2017]

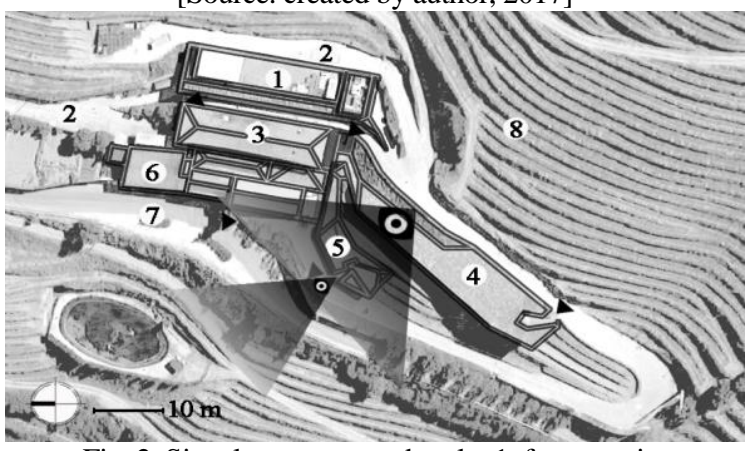

Fig. 2. Site plan - courtyard scale: 1 . fermentation warehouse; 2 . production area/service road; 3 . old winery;

4. hogshead warehouse; 5. reception / visitors entrance;

6. ancillary buildings; 7. visitors / residents parking area / road / entrance; 8 . terraced vineyard [Source: created by author, 2017]

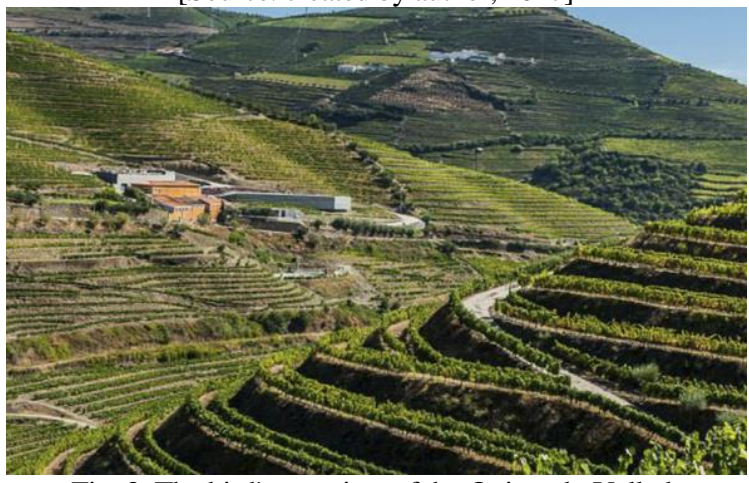

Fig. 3. The bird's eye view of the Quinta do Vallado [Source: https://www.facebook.com/quintadovallado/ (Accessed 19, April 2017)]

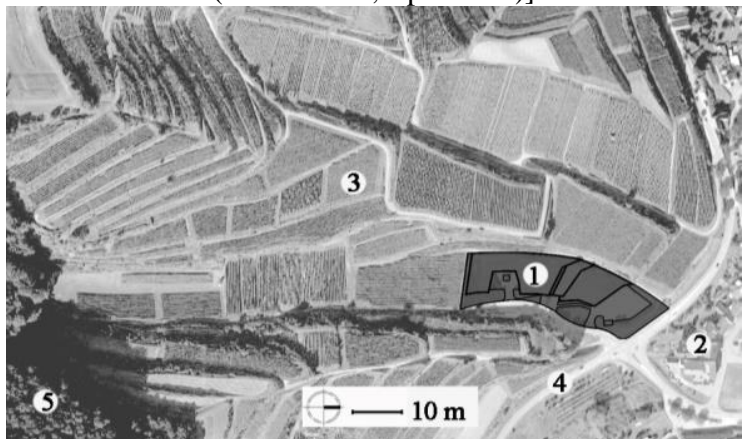

Fig. 4. Site plan - the relevance to the landscape pattern: 1. built area; 2. Oberbergen town; 3 . terraced vineyards;

4. Bergstrasse - route of mountains, wine, and castles;

5. Black Forest [Source: created by author, 2017] awards. This recognition increased demand for the wines, so in 2006 , the proprietors were already thinking about extending the estate [3]. The expansion project included two areas of intervention - production and leisure - completed in 2010 and 2012 by Guedes + de Campos Architects.

"According to the architect, the project was supposed to "ideally blend into the natural landscape and not look too bulky and heavy". For Vieira de Campos, there were two key aspects: making use of traditional regional building materials, and emphasizing the building's relationship to the surrounding landscape" [3].

The estate's vineyards, shaped by the meandering water plan of the river, are planted on the steep hillsides and are divided in elegant patterns, which are characterized by smooth and curved edges. Most of the vines are planted in horizontal, continuous rows, on handbuilt stone terraces or bulldozed earth terraces, and some on unterraced plots. The vines' rows follow the ground lines and are bordered by olive trees and punctuated by the Italian-cypress. The built area is set in a dominant and strategic position taking advantage of the network of curved pathways (Fig. 1). The new volumes of winery - Fermentation Warehouse, Hogshead Warehouse and Reception - create a relation of tension and balance between old buildings and topography, merging in the land declaring its artificial nature. The entire production area is organized in terraces, supported by retaining walls of schist and granite, the staircases and balustrades. The silver-grey structures, coated with local burnt shale worked in a contemporary way, imitate the natural form of the slope. The Fermentation Warehouse has parallelepiped layout and is embedded in the ground. The Hogshead Warehouse and Reception represent a big encrusted mass in the field and ends in a cantilevered beam. The linear shape of the building stretches along the layers, while it is also partially embedded in the ground. All the guest entrances and passageways offer friendly decors and amazing views (Fig. 2, 3)

Franz Keller Winery (2013, architects: Geis and Brandtner), with its 57 hectares of vineyards, lies at the foot of the Badberg (nature reserve), in a blind valley of the Kaiserstuhl mountains. The estate is best known for producing dry wines reflecting the extraordinary terroir of the Kaiserstuhl and these wines have found international recognition as outstanding ambassadors for Baden's wine culture.

"The new Franz Keller winery is a very clear illustration of how everything to do with wine is changing in Central Europe. [...] If the natural surroundings are taken into account and the processes of harvesting, storing, pressing and again storing are logically incorporated into the plans, the result will be successful structure such as the "invisible" terraces of Oberbergen" [4]. 


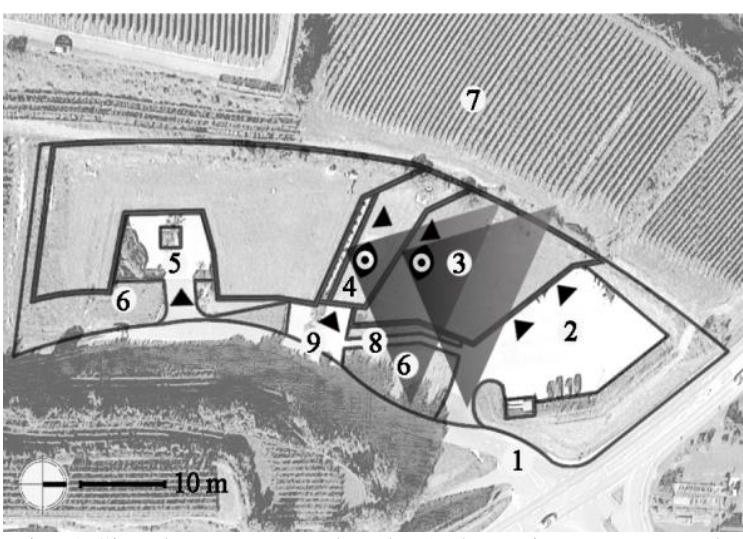

Fig. 5. Site plan - courtyard scale: 1 . the main entrance on the winery's territory; 2 . visitors/residents parking area/ entrance for employees; 3-4. terraces/exits;

5. multifunctional yard; 6 . green surfaces; 7 . Vineyard;

8-9. stairway leading to the entrance for visitors/entrance

[Source: created by author, 2017]

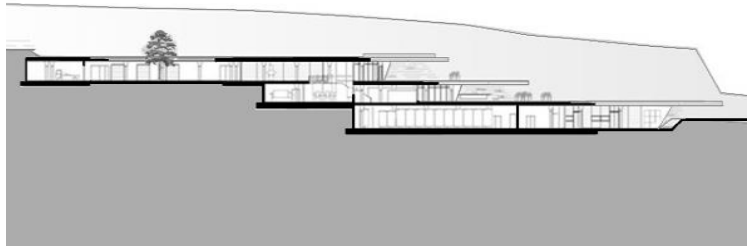

Fig. 6. Longitudinal section of the winery [Source: https://www.beton.org/inspiration/ (Accessed 19, April 2017)]

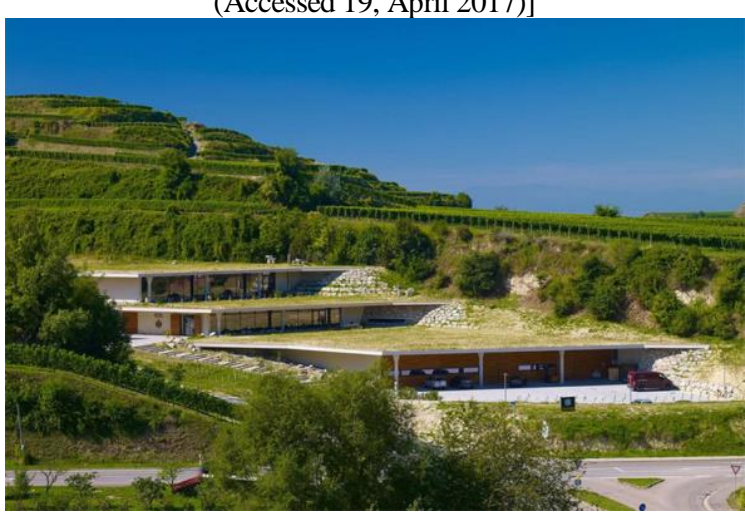

Fig. 7. The "terraced building"

[Source: https://www.beton.org/inspiration/

(Accessed 19, April 2017)

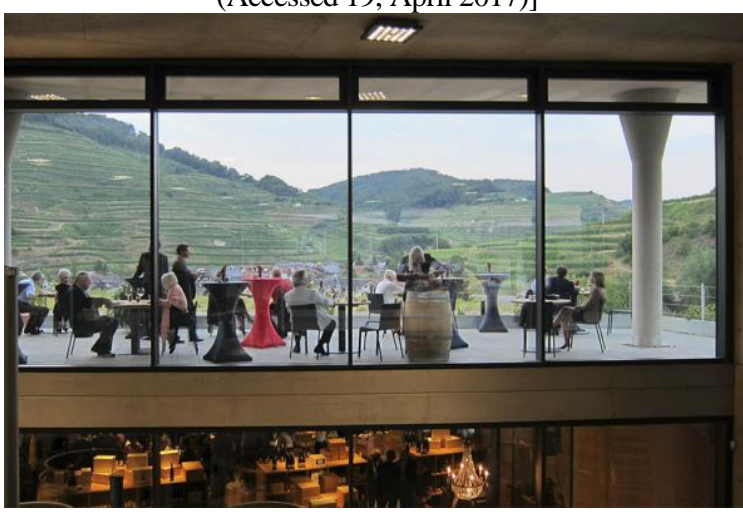

Fig. 8. The view towards landscape

[Source: https://www.facebook.com/

FranzKellerSA/photos (Accessed 19, April 2017)]
The estate's vineyards, shaped by the Black Forest, volcanic hills, small town of Vogtsburg-Oberbergen and roads, are grown on terraces and steep slopes that follow the contours of the old volcanic cones. This productive land is divided in dynamic, irregular patterns characterized by the rows of vines with different orientations (Fig. 4). The building footprint, almost invisible above ground, was shaped by the adjacent plots. The building seems to be the continuation of the terraced vineyard levels, it extends towards the settlement but does not reach it (Fig. 5). The terraced building is partly sunk into the ground and covers three levels, where each step in the wine process strategically takes place on a specific floor (Fig. 6). Surrounded by the well-harmonized green environment, it is an expert mix of natural and sustainable materials such as glass, stone and wood (Fig, 7). Its green terraced roof follows the shape of the hill and is covered with a layer of soil up to four meters and planted with grassy seeds from neighboring Badberg nature reserve. The reinforced concrete structure, the tapered columns and the huge windows make the building open and communicative both inside and outside. The interior provides interesting insight into the production processes and a unique panoramic view from the terraces (Fig. 8).

Antinori Winery (2012, Arch: Archea Associati) is located within vineyards in the rolling landscape of the hills of the Chianti region, on the road between Siena and Florence. In 2015 it received the European Union Prize for Contemporary Architecture - Mies Van Der Rohe Award.

"The physical and intellectual construction of the winery pivots on the profound and deep-rooted ties with the land, a relationship which is so intense and suffered as to make the architectural image conceal itself and blend into it," says Archea Associati [8].

The estate's vineyards, shaped by the hills studded by cypresses, forests, roads and a small town, are grown on gently undulating hills. The land is divided in irregular, sinuous patterns (Fig. 9). The industrial complex's body, built almost completely underground and shaped by the adjacent roads, extends horizontally along the natural slope, paced by the rows of vines which, along with the earth, form its "roof cover" (Fig. 10). "The invisible building", divided into two floors with different levels (Fig. 11), is designed in earthy colours and marked by two horizontal cuts that follow the curves of the hilly land. The first cut is closed by large glazed fronts, while the second, upper one, is closed by walls and gates in Corten steel. The used materials, Corten steel, red facing bricks, oak and glass, perfectly harmonize with the natural charm of the surrounding countryside. The structure 


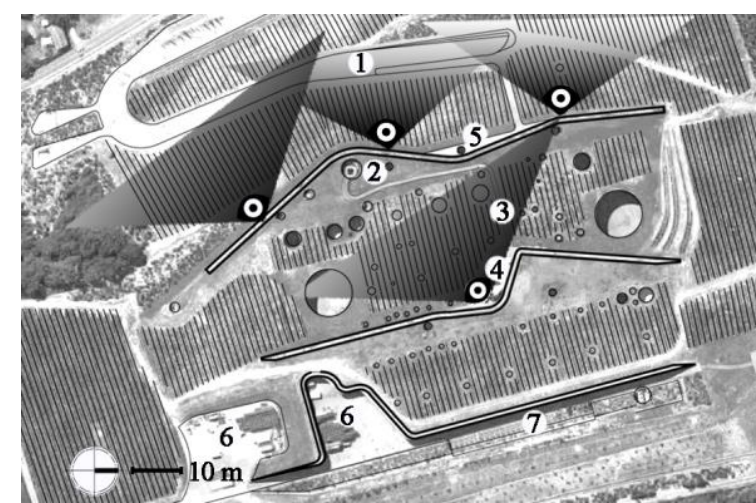

Fig. 10. Site plan - courtyard scale: 1 . main entrance on the winery's territory; 2 . spiral staircase, which ascends from the underground parking to the balcony; 3 . vineyard;

4. terrace /gates; 5 . panoramic terrace/exits 6. multifunctional yards - production/ transportation facilities;

7. parking area for employees [Source: created by author]

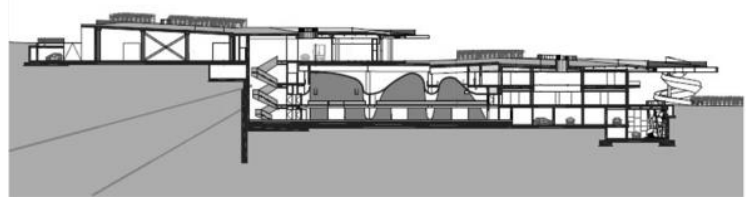

Fig. 11. Cross-sectional view

[Source: http://www.promozioneacciaio.it (Accessed 19, April 2017)]

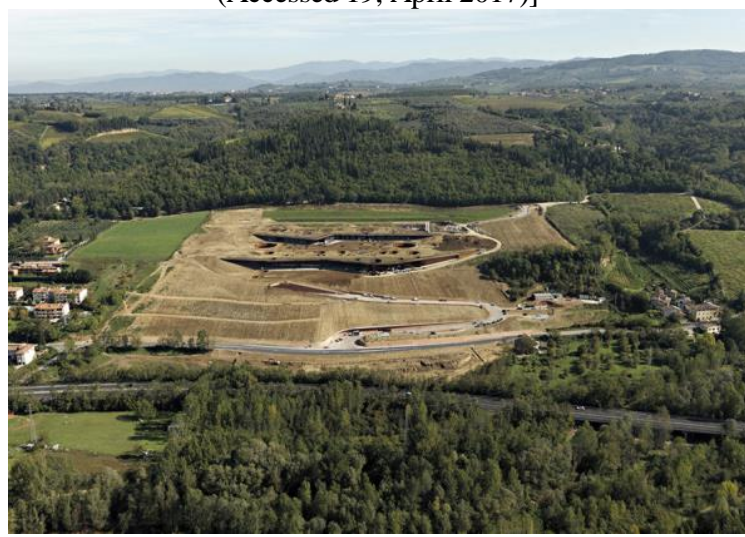

Fig. 12. The bird's eye view of the "invisible building" [Source: http://www.archdaily.com (Accessed 19, April 2017)

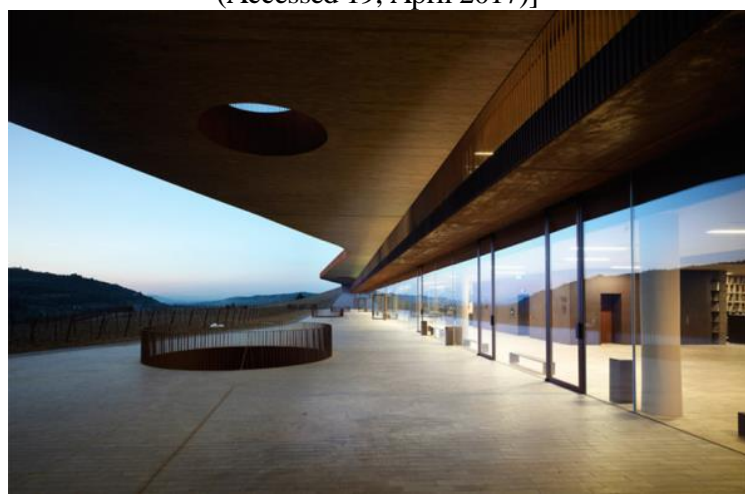

Fig. 13. The first cut - the panoramic terrace shaded by the roof [Source: http://www.designboom.com (Accessed 19, April 2017)] has a green stepped roof, completely covered by vineyards, and is pierced by a couple of brown, circular openings, which bring the light into the depths of it. One void contains a large spiral staircase, which ascends from the underground parking to the balcony on the vines (Fig. 12). The volume opens to the landscape through the first cut, which is visible from the exterior and leads to the spacious panoramic terrace shaded by the roof, offering to the visitors a panoramic view of the surrounding landscape (Fig. 13).

FX. Pichler Winery (2009, Arch: Thomas Tauber), one of the icons of Austrian winemaking and viticulture, is situated in the Wachau Valley, between the hillside vineyards of Loiben, the ruins of Dürnstein castle and the Danube River.

"The long, flat-roofed building is in no way showy; it is not even located on the main road, but tucked away behind an old vintner's house, leaving the landscape of the Wachau undisturbed" [3].

The winery's vineyards, comprising 18 hectares, are concentrated on the southern side of the Danube and are planted in steep terraces and slopes, originating from the 13th century. Shaped by the river, settlements, forested hills and roads, the productive land is divided in geometric, regular patterns (Fig. 14). The parallel rows of grapes guide the shape of the parking lot to the footprint of the building (Fig. 15). Situated on a flat terrain, the two-storey prism is faced with dark grey and anthracite-coloured concrete panels. The handground and sanded concrete with inclusions of a green stone give result of rough heterogeneous surface, which is reminiscent of the traditional stone walls that are so typical of this region. On the main facade a contrasting band of aluminium laths rises up from the ground and optically connects the glass section of the building (Fig. 16). The curved, wave-like aluminum appliqué reflects the Danube River, which lies beside it. On the other side, a generous glass facade, covering customer area, reflects the vines and offers a panoramic vista of the vineyards and surrounding landscape (Fig. 17).

The Lavaux Vinorama (2010, Arch: FournierMaccagnan) was built as a "teaching and social centre" [3] on the most stunning vineyard landscape. The project won the 2013 Architizer A+ Jury Award in the bars \& nightlife category.

The site is characterized by the terraced vineyard, the lake and the stream running from the Forestay River - offering a division of the land as well as unique structural element (Fig. 18). Compared to the earlier examples this project misses the production facilities of an usual winery, it focuses on wine tasting and selling. The building has a monolithic cube nestled like a fortress into the steep slopes, emulating the rocky cliff where grape vines enjoy the warm and moisture-laden air. 


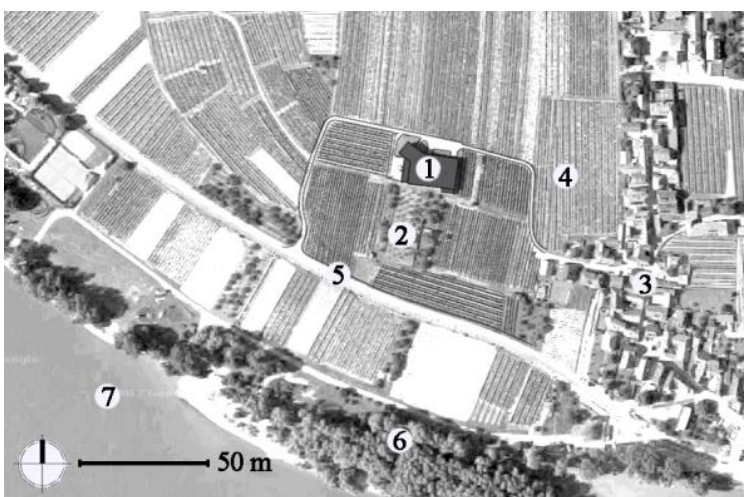

Fig. 14. Site plan - the relevance to the landscape pattern: 1. built area; 2 . orchard; 3 . Oberloiben town; 4. vineyard; 5. Danube Federal road 3; 6. green mass; 7 Danube River [Source: created by author, 2017]

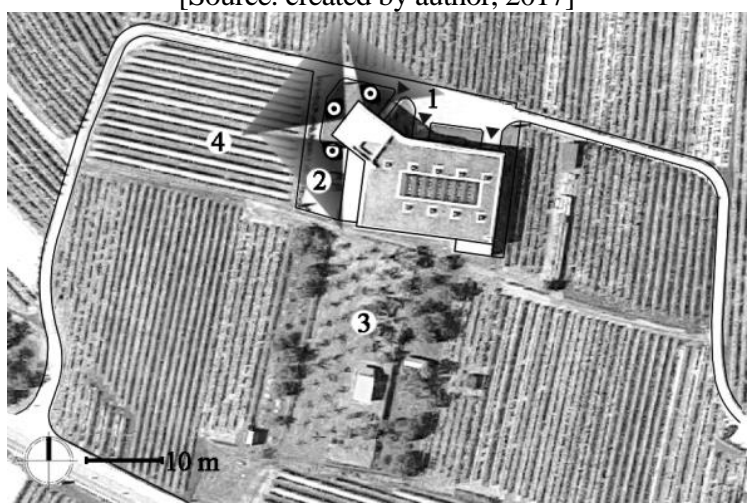

Fig. 15. Site plan - courtyard scale: 1. entrances / parking area for visitors / employees; 2. multifunctional yards;

3. orchard; 4. vineyard [Source: created by author, 2017]

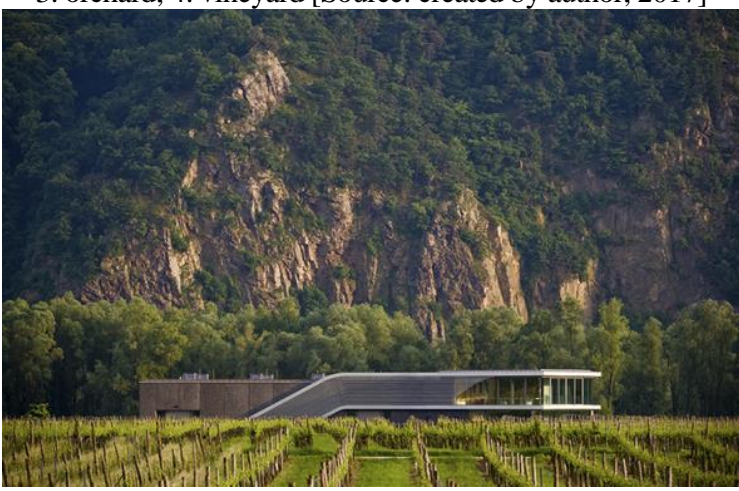

Fig. 16. FX.Pichler Winery [Source: http://www.loxpix.com/ spaces/winery (Accessed 19, April 2017)]

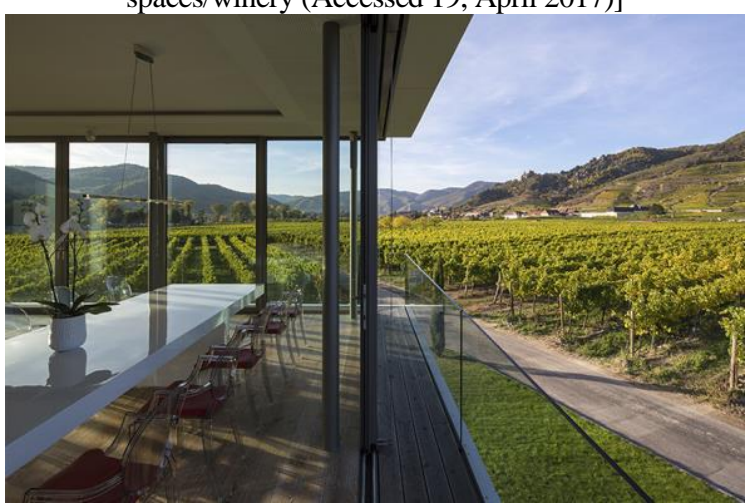

Fig. 17. The panoramic view from customer area [Source: http://www.loxpix.com/spaces/winery (Accessed 19, April 2017)]

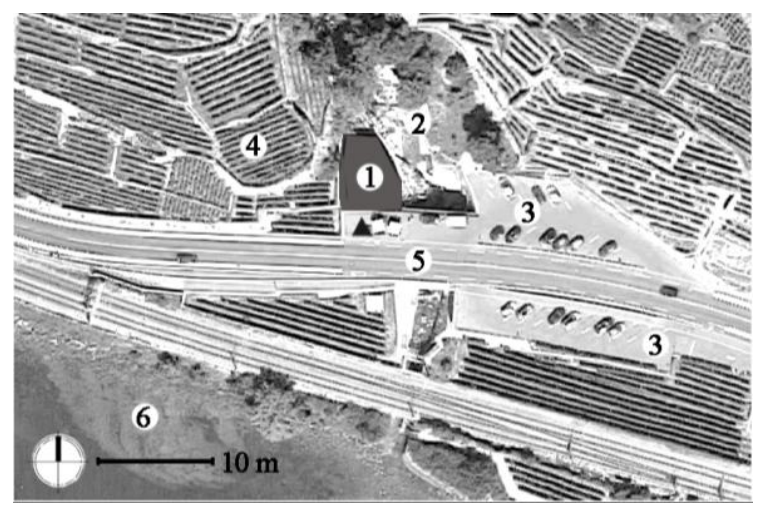

Fig. 18. Site plan - the relevance to the landscape pattern:

1. built area; 2. Forestay cascade; 3. parking area for visitors / employees; 4. vineyard; 5. lake road; 6. Lake Geneva

[Source: created by author, 2017]

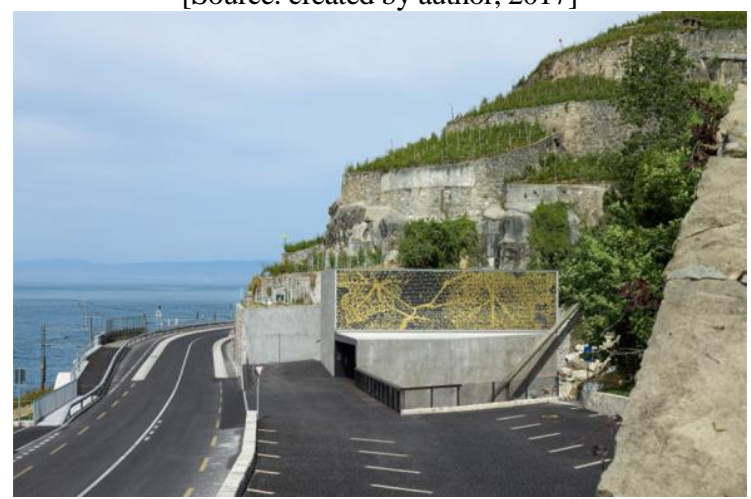

Fig. 19. Lavaux Vinorama

[Source: http://www.lavaux-vinorama.ch/fr/N355/levinorama-en-images.html (Accessed 19, April 2017)]

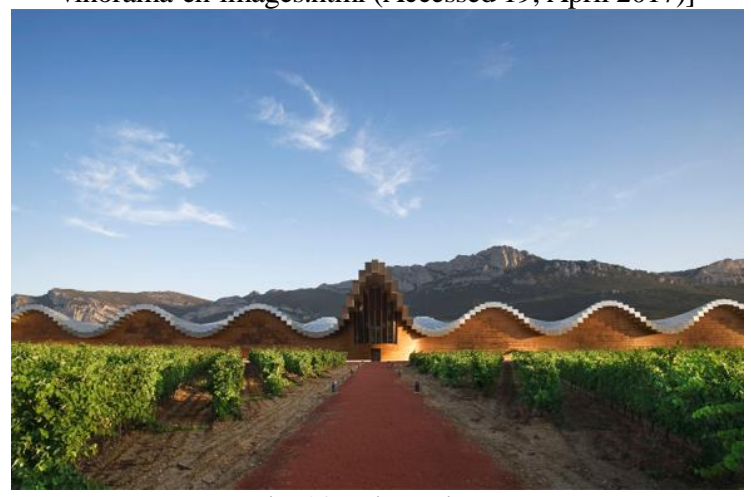

Fig. 20 Ysios Winery

[Source: http://buildipedia.com (Accessed 19, April 2017)]

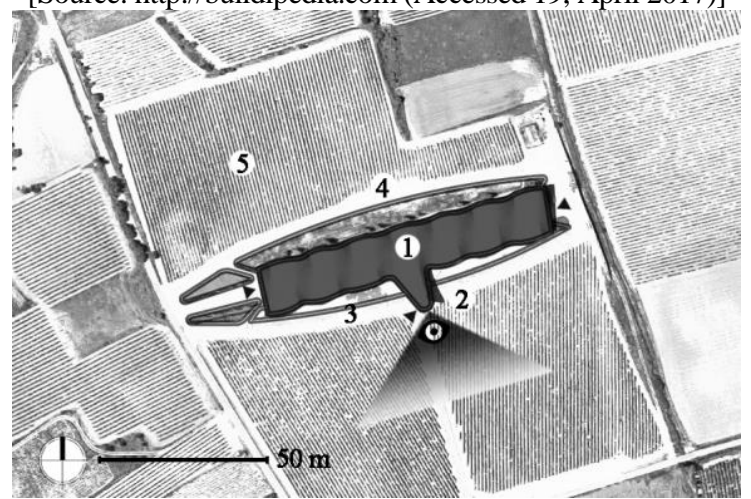

Fig. 21. Site plan - courtyard scale: 1 . built area;

2. main entrance; 3.pool; 4. parking lot / green area; 5. vineyard [Source: created by author, 2017] 
The facade is covered by a sculptural steel rainscreen, designed by Swiss artist Daniel Schleapfer (Fig. 19). Its pixelated surface depicts grapevines, which impart a dappled light to the interior tasting rooms. From here the cascade, vineyards and lake are visible - the only place in the structure from where these may be viewed.

The jurors appraised the architects strive to fit into the historic and natural context. ,They chose to build with concrete- a material both historic and modern, used by the ancient Romans and Swiss modernists. To pay further homage to local building traditions, the concrete was composed of local sand and aggregate, physically including the earth of the site into the structure" [9].

Ysios Winery [5] (2001, Arch: Santiago Calatrava), pixelated-looking landmark, is located at the foot of the Sierra de Cantabria mountain range, in the Rioja Alavesa region.

The vineyards of Ysios winery, shaped by mountain range and roads, comprise 75 hectares and are grown on the terraces and gentle slopes. The site is divided in dynamic, irregular patterns characterized by the vine's rows with different orientation. The rectangular structure, situated on a flat terrain, represents a ruled surface wave, which combines concave and convex surfaces as it evolves along the longitudinal axis. The body of the building is made out of copper stained cedar boards - bearing resemblance to that of giant wine barrels - precast concrete panels and fret aluminum plates. The wavy roof follows the silhouette of the surrounding mountain range and is made of gigantic, aluminum bars (Fig. 20). From a bird's-eye perspective, the bars of the roof seems to be guided by the orientation of the vine's rows from adjacent patterns or vice versa (Fig. 21). In the middle of the building, the roof pitches steeply upwards and extends far forward, forming a giant glass-paneled balcony. This raised center marks the entrance to the winery and offers to the visitors a majestic view inside of the winery as well as out over the vineyards. At the foot of the building stretch two lateral pools, lined with white ceramic tiles create a mirror-like reflection.

\section{Conclusions}

Site

The rhythm and geometries of the agricultural landscape patterns influenced and shaped the architecture of the Lavaux Vinorama, Quinta do Vallado, Franz Keller and Antinori wineries. In their design the unique site characteristics were considered, such as natural topography, natural contours of the site, terrain-modelling, the local setting, scenic vistas etc. The built forms are located in the least environmentally sensitive location, thereby minimizing their impacts on natural terrain of the project site.

Connection with the terrain

There are fundamentally different approaches among vineyards regarding construction on the level or on a slope. The Lavaux Vinorama, Quinta do Vallado, Franz Keller and Antinori wineries prove that the concept of a winery embedded in a slope is the most convenient, not only for the production process, which utilizes the gravity, but also for achieving a harmony between site and architecture.

Basic visual elements - Materials

To mitigate the visual impacts of building mass and to fit it into the natural scenography/local settings, beside the relevance to the landscape patterns and connection with the terrain, the use of materials also play a leading role. In the case of Quinta do Vallado, the use of local materials, such as schist, granite and burnt shale worked in a contemporary way, made the volume blend in with the predominant colours of the surrounding landscape. Designed in earthy colours and made of natural, sustainable materials such as glass, stone, wood, corten steel, bricks, the Franz Keller and Antinori wineries are perfectly fit into the fascinating surroundings. In the case of FX.Pichler, Lavaux Vinorama and Ysios wineries the structure design and materials are visually sophisticated and has symbolic reference to the site. The used materials for FX.Pichler and Ysios wineries provide strong, natural accents and mimic the rocks of the mountains behind them.

Basic visual elements - Roof shape

The green terraced roof of the Franz Keller and Antinori wineries follow the shape of the hills and blend in with the predominant colours of the surrounding landscape. The shape and colour of the Ysios winery has a metaphoric/symbolic reference to the site. The wavy form of the roof recalling large barrels lying side by side and connected by a band of silver, and at the same time it follows the silhouette of the surrounding mountain range. Basic visual elements - View spots

As was mentioned above, the new wineries do not serve only for collecting and producing, but also for "selling" the landscape. All the examples comprise the view spots, which offer to the visitors a view over the vineyards, with the exception of the Franz Keller and Antinori wineries. The terraced buildings are marked by huge glazed fronts, which make them open and communicative both inside and outside, providing a unique panoramic view.

This short study underlines, that architecture can be viewed in greater context, especially if there is a strong need to observe the surrounding landscape. There seems to be a tendency to harmonize architectural composition within the landscape characters and patterns. Wine-design discovered how to use landscape as a brand-making factor, where not only the view from the terraces is crucial, but the view on the whole intervention within the agricultural landscape. The tendency is clear: more-and-more care is taken on toning architecture to the factors of landscape. 


\section{References}

1. Tarolli, P., Sofia, G., Calligaro, S., Prosdocimi, M., Preti, F., Fontana, G.D. Vineyards in terraced landscapes: new opportunities from lidar data. Land Degradation \& Development, 2015, No. 26, pp. 92-102.

2. Architecture and Wine in Central Europe = Architektur und Wein in Mitteleuropa. [ed. Dan Merta] Praha: Galerie Jaroslava Fragnera \& Architectura, 2013, pp. 9, 20.

3. Woschek, H.-G., Duhme, D., Friederichs, K. Wine and Architecture. Munich: Edition Detail, 2012, pp. 10, 16, 18, $19,45,123,125$

4. Meyhöfer, D., Frahm, K. The Architecture of Wine. Stuttgart: AVEdition, 2015, pp. 14, 114

5. Webb, M., Pfeiffer, E. Adventurous Wine Architecture. Mulgrave: The Images Publishing Group, 2005, pp. 6, 10.

6. Simon, M., Harea, O. Terraced Vineyards - Architectural Responses. 4D Journal of Landscape Architecture and Garden Art, 2017, No. 44 (in press).

7. Meyhöfer, D., Gollnek, O., Hubschmid, P. C. The Architecture of Wine = Die Architektur des Weines = L'architecture du Vin. Corte Madera CA: Gingko Press, 2000, p. 23.

8. Antinori Winery, 11, February 2017, [online 19.04.2017] https://en.wikiarquitectura.com/building/ antinori-winery/

9. Tucked Into A Cliffside, A Swiss Winery Preserves The Landscape-And Wows Guests, 5. April 2013, [online 19.04.2017] http://architizer.com/blog/tucked-into-a-cliffside-a-swiss-winery-preserves-landscape -and-wows-guests/

INFORMATION ABOUT THE AUTHORS:

Olga Harea MSc. Architect. Graduated Technical University of Moldova, Faculty of Architecture and Urban Planning. PhD student at Szent István University, Faculty of Landscape Architecture. In the PhD research she focuses on the contemporary architecture and their forms of fitting into local landscape character, especially in the wineries topic. E-mail: hareaolga@gmail.com

Anna Eplényi PhD. MSc. Landscape Architect and BA. Art-teacher, leader of Children Art Studio Foundation (www.gyikmuhely.hu). Since 2015 Senior Lecturer at the Dept. of Garden Art and Garden Techniques at the Szent István University (Budapest) teaching various creative topics (drawing, sketching, modelling, garden art). E-mail: eplenyi.anna@tajk.szie.hu

Kopsavilkums. Pēdējos gados vīna ražošanas kultūru aizvien vairāk ietekmē ekonomiskie apstākḷi, tai pārdzīvojot pārmaiņas, un vīna ražošanu aizvien vairāk saistot ar atpūtu un izklaidi. Paralēli vīna ražošanai attīstās arī vīna kultūru reprezentējoša ēku formveide un dizains, kas veido svarīgu aspektu vīna firmu zīmola atpazīstamībai. Tam pamatā ir viens no galvenajiem kritērijiem mūsdienu vīna kultūras attīstībā - arhitektūras formveides un modernisma stilistikas meklējumi ainavtelpā, saglabājot vīna ražošanas tradīcijas un noslēpumus.

Pētījumam ir izvēlētas sešas vīna ražotnes, kas atrodas īpaši aizsargātā kultūrainavā, aplūkojot divus galvenos aspektus: konteksts (atbilstība ainavtelpai, formveides kopsaskaņa ar reljefu, skatu punkti) un arhitektūras formu dizaina detālie elementi (materiāli, jumta forma, formas imitācija). Pētījuma secinājumi liecina, ka trīs no aplūkotajām vīna darītavām - Lavaux Vinorama, Quinta do Vallado, Franz Keller and Antinori - arhitektūras kompozicionālajā valodā ir spēcīgi ietekmējušās no vīna dārzu ritma un geometrijas. Būtiski, ka šo vīna darītavu arhitektūrā ir ņemti vērā unikālas dabas pamatnes īpašības reljefs, ainavas robežas, esošas būves, gleznainie skati, utt. Jaunie arhitektūras elementi ir izvietoti vismazāk vizuāli konfliktējošajās vietās, tādējādi mazinot to ietekmi uz kultūrainavu. Mūsdienīgi risināti ir vīna darītavu Franz Keller un Antinori zaḷie jumti, kas atkārto kalnu formas un kolorītu. 


\title{
The European fortifications on the coast of the Pacific Ocean
}

\author{
Nikolay Kasyanov, Research Institute of Theory and History of Architecture and Urban Planning \\ of the Russian Academy of Architecture and Construction Sciences, Moscow, Russia
}

\begin{abstract}
In the Russian Empire during XIX and early XX centuries, fortresses were built and strengthened along the frontiers. We studied the architecture of the Far Eastern Russian cities-fortresses using as examples Nikolaevsk-on-Amur, Port Arthur (now Luishun) and mainly Vladivostok. Coastal fortresses significantly influenced the urban development of the Far Eastern cities. The architectural peculiarity of the fortress architecture at that period was associated with the transition from the brick and stone fortifications to the complex systems of monolithic reinforced concrete. In 1860, a military post with the expressive and geopolitically ambitious name "Vladivostok" ("Possess the East") was established. By the beginning of the XX century, Vladivostok became a rapidly growing city of the European culture and one of the most powerful marine fortresses in the world. The Vladivostok Fortress was an innovative project in early XX century and has distinctive features of the modern style (Art Nouveau), partly of the Russian and classical style in architecture, as well as an organic unity with the surrounding landscape. Plastic architectural masses with their non-linear shape are typical of the fortifications of Vladivostok. Vast and branching internal communication spaces link fort buildings, scattered on the surface and remote from each other. Huge, monumental forts located on the tops of mountains and fitted perfectly in the landscape are successful examples of landscape architecture. The Vladivostok Fortress was the last huge marine citadel of the Russian Empire but not completed and turned into a Utopia. Now Vladivostok Fortress is proclaimed a monument to the past and architecture of the Russian Federation. Today, after nearly 100 years, a new large-scale innovative program for Vladivostok is being implemented, with the development of the adjacent island territories and the construction of modern large-span bridges.
\end{abstract}

Keywords: marine fortress, architecture, Pacific Ocean, Port Arthur, Vladivostok

The world history of the defensive architecture can be traced back through fortifications changing each other for several generations and the dependence of their forms on the development of military and construction technologies is clearly identifiable, defining both the constraints and new opportunities in the architectural form creation and urban planning. Thus, the large, kilometers-long diameters of forts allowed enough freedom to develop urban planning for cities within their perimeter. Such fortresses were often constructed around the existing cities with an established building structure. A feature of marine fortresses was the need for a good, sheltered bay with the takings to the sea, covered with islands and capes. The Russian military defensive architecture has long been developed in conjunction with the architecture of its time and had been influenced by architectural traditions. By the end of the $19^{\text {th }}$ century, it was concluded that the traditional brick fortifications were unsuitable. A short but important and striking final stage can be singled out in the evolution of fortresses - concrete defensive architecture at the turn of the $19^{\text {th }}$ and $20^{\text {th }}$ centuries.

In the Russian Empire of the $19^{\text {th }}$ and early $20^{\text {th }}$ centuries, fortresses were built and improved on the border areas, especially in its European part. The protection of coastal areas and major cities was conducted in the Baltic and Black Seas, as well as the Pacific Ocean (Fig. 1). During the expansion of the Russian Empire, the Russian vector and, thus, the European influence had reached, as we know, Harbin, Port Arthur, the Far East in Asia (China), California, Alaska in America, and even Hawaii. In 1860, Ensign N.V. Komarov and Lieutenant G. H. Egersheld with a detachment of soldiers and sailors founded a military post, receiving an expressive and geopolitically ambitious name "Vladivostok". The other posts were named Slavyanka and Novgorod. Such geographical names as the bay of Peter the Great and America (now Nakhodka Bay), Eastern Bosphorus Strait, the islands Russky, Askold, the bays Zolotoy Rog, Olga, Vladimir, Voyevoda, Vityaz, Boyarin, París, Patroclus, Diomedes, Ulysses, Ajax were given by Russian military and civilian researchers using historical, geographical, and even mythological reminiscences. By the early $20^{\text {th }}$ century, movement of Russia to the East was completed. On the coast of the Pacific Ocean, the defensive development priorities were sequentially received by Okhotsk, Petropavlovsk in Kamchatka, Nikolayevsk-onAmur, Vladivostok, Port Arthur, and with its loss - again Vladivostok.

In this area, there were military and research vessels of different countries, in particular, English. It is curious that the British managed to give their names to certain geographical points, for example, the archipelago of Empress Eugenia (RimskyKorsakov Islands), Cape Sandy, Termination Island. 


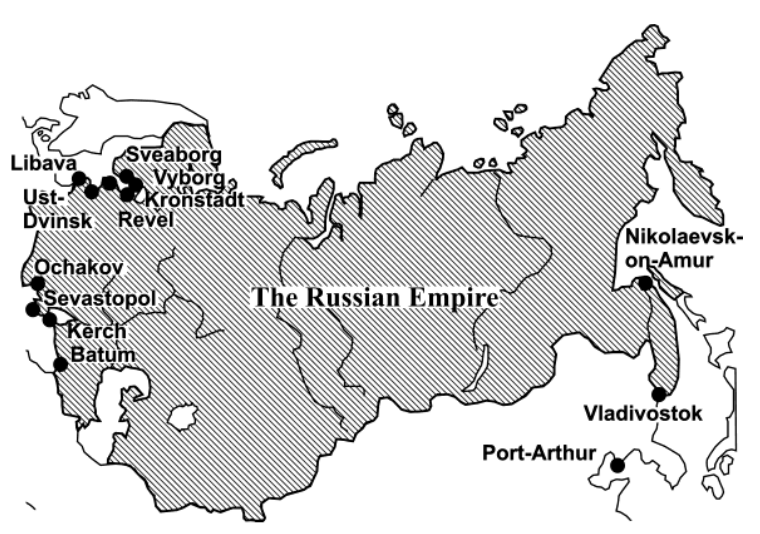

Fig. 1. Coastal fortresses of the Russian Empire in the beginning of XX century

[Source: from author private archive]

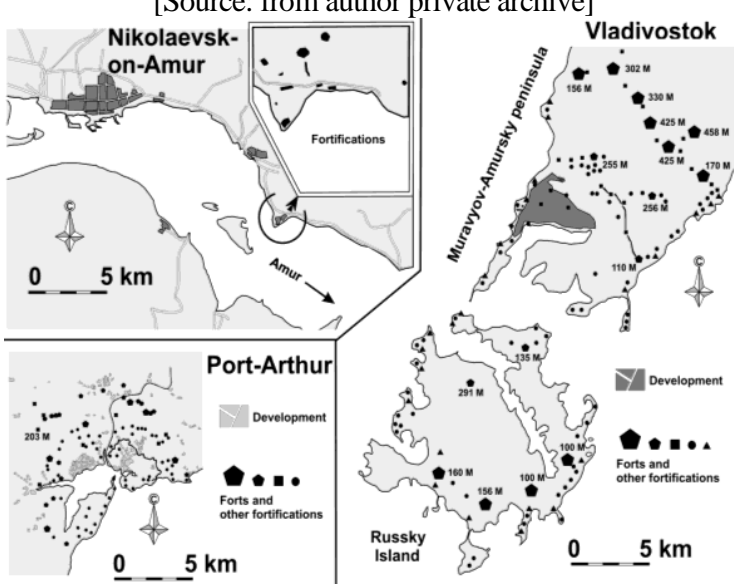

Fig. 2. Schemes of Far Eastern cities-fortresses: Nikolayevskon-Amur (top left); Port Arthur (bottom left); Vladivostok and its system of fortifications on the Muravyov-Amursky'

Peninsula and the Russian Island, to the right

[Source: material from author private archive]

This island is near Vladivostok, later named - Askold.

It is necessary to note the amazing beauty of the nature of these places, especially the Khasansky region - a rugged, rocky coastline on which the Korean grave pines grow, interspersed with rocky and sandy bays and coves with emeraldgreenish pure water. A lot of different marine organisms and animals live here, some of which are listed in the Red Book. Among the "Hills of Manchuria", there are the habitats of the Far Eastern leopards, tigers, and spotty deer.

The area of the present Far East with significant reserves of minerals, forest, and fishery resources by the middle of the XIX century, when the Ussuri region was finally incorporated into the Russian Empire, was practically undomesticated. The domestication of the region began during the development of capitalism almost simultaneously with the abolition of serfdom - which did not exist in the Far East. The Russian government sought to gain access to the ice-free seas. The foundation in 1850 of the Nikolaevsky Post at the mouth of the Amur actually confirmed the belonging of the Amur Region to Russia and formed a new river outlet of Russia to the Pacific Ocean. The Nikolaevsky Post was named Nikolayevsk-onAmur and became a military port and residence of the military governor. By the end of the $1850 \mathrm{~s}$, the port of Nikolayevsk-on-Amur was begun to be visited by merchant ships from San Francisco, Boston, and Hamburg. The city was actively developing, its area to the beginning of the 20th century amounted to 420 acres. In the city, there were 189 quarters, 24 streets, and 5 lanes [1]. Almost an orthogonal network of streets of Nikolayevsk-on-Amur was slightly bent, repeating the outlines of the banks of the Amur. The fortress was characterized by a combination of two fronts: the river one with coastal batteries and the land one with redoubts and other fortifications. Engineers tried to make maximum use of the terrain with coastal hills up to 160 meters in height. The main objects of the future fortress, defending the mouth of the Amur, were built on the left bank, on Chnyrrah Cape (Fig. 2). Wood-and-earth fortifications of a semi-long-term nature were erected. This fortress, which provided the possibility of safe construction of Nikolayevsk-on-Amur, did not have a direct effect on the development of the planning structure of the city itself since its main structures were concentrated closer to the mouth of the Amur [2, 3].

In the late $19^{\text {th }}-$ early $20^{\text {th }}$ centuries, there was a kind of "competition" between Russia and Germany, two superpowers of that time, involving the Asia-Pacific region as well. In 1897, the Chinese city of Qingdao was transferred under the concession of Germany and turned into a fortress and a strategically important port by the Germans. With the aim of domestication of the new areas of Russia and their economic development in the late $19^{\text {th }}$ century, the program of the settlement of the Far East by peasants from the European part of the Empire operated. Russia built the Trans-Siberian Railway and the Chinese-Eastern Railway. For access to the non-freezing Yellow Sea in 1898, the Tsarist Government of Russia leased a part of the Liaodong Peninsula from China for 25 years, with a view to locate the Russian military-naval Port Arthur fortress and the trading port Dalniy there. The future city-fortress was surrounded by two mountain ranges, with heights of up to $200 \mathrm{~m}$ above the sea level. The plan of 1898 to build a fortress included landlines of defense stretching around $70 \mathrm{~km}$ and the garrison with at least 70 thousand people, however, it was rejected as being too expensive. As a result, the landline of the defense, designed by Professor K. I. Velichko amounted to only about $19 \mathrm{~km}$ [3]. In his report, he wrote, "Such a topography, soil, and surface characteristics were not seen in any of our fortresses" [4, 222]. The completion of the 
construction works was scheduled in 1909; the total value of the fortress was to make about 15 million roubles. The line of the designed fortifications was placed on the tops of the mountains surrounding the bay and the city in a semicircle (Fig. 2).

The plan of the city was not orthogonal, areas with rectangular blocks clustered around several squares at the intersection of the major streets. The planning took into account the local landscape, part of the streets was entered in the terrain, though many of them were tried to be made straight. The panorama of the city was limited to high and steep hills, surrounding it in the perimeter. Innovations of the military architecture were linked there with the need to design and construct a fortress in the conditions of the difficult, mountainous terrain. The new forms brightly emerged in the cast concrete buildings of the coastal batteries with crossbars and direct through tambours with rounded corners, broad, expressive in plastic stairs to the cannon yards with concrete parapets. The traditional architectural decoration was also applied: embrasures of forts were built of stone, the walls of the fortification were coated with stone, topped with massive cornices. They are characterized by delicate decorating and architectural processing, profiling of many ancillary parts and structures.

The planning structure of the urban centers, integrated in the early $20^{\text {th }}$ century by the Russian architects in the cities of Port Arthur and Dalniy is still evident in the present Lushun and Dalian. The names of the streets in Dalniy symbolized the relationship of the new city built by the Russians with Russia - Petersburg Quay, Moskovskoye shosse, Kievsky, Vladimirsky, and Moskovsky Prospects, Red Square [5, 6, 7]. In Lushun, a significant number of Russian fortifications has been preserved, dominating on the tops of coastal hills above the city.

In 1904, the fortress of Port Arthur was actually half-built. For the purpose of saving money, the diameter of the fortress did not meet the necessary requirements, and the whole city with the port could be pierced through by the artillery of the enemy. From the harbor, there was only one narrow exit, and the outer roadstead was fully opened. Having withstood the storms, on December 20, 1904, the fortress (old style) was occupied by the Japanese.

In the meantime, Vladivostok was built at the southwestern extremity of the peninsula reaching into the Sea of Japan, which reaches a length of about $30 \mathrm{~km}$, the width of about $15 \mathrm{~km}$. A city with a well-protected harbor located on the banks of the Golden Horn Bay, reaching $7 \mathrm{~km}$ into the peninsula (Fig. 2). In 1862, the post of Vladivostok officially became a port with the right to the duty-free trade of foreign goods, which contributed to the development of the international trade. The first Russian immigrants arrived by sea to Vladivostok in 1865 . The Muravyov-Amursky Peninsula is washed by the Amur Bay from the east and Ussuri Bay from the east. The city has a good external raid and two exits in these bays, separated by a group of islands that make up as if a continuation of the MuravyovSmursky Peninsula [8, 9, 10]. In contrast to Port Arthur, here on one bay, the commercial and military port was located.

The first general plan of Vladivostok with an orthogonal network of streets and the squares of city blocks was designed in 1868. The rectangular quarters of the urban building are the result of great work in moving land masses for straightening the streets and reducing their slopes. In 1871, by the Government decision, Vladivostok becomes a Navy base and the main port of Russia in the Pacific Ocean but in 1873 - a base of the Siberian Flotilla. Having received the city status in 1880 , by the end of the $19^{\text {th }}$ century, Vladivostok became the center of numerous projects related to the development of the Eastern Siberia territories, fisheries, mining. The interest of foreign powers to the territory required strengthening of the positions of the Russian Empire on the shores of the Pacific Ocean. For this purpose, in 1899, Vladivostok was proclaimed a naval fortress, over the fortifications of the city a flag was raised $[8,11]$.

By the end of the $19^{\text {th }}$ century, Vladivostok turned into a booming city of European culture, formed due to the intense activity of Russian military engineers-architects, the officer corps, and business people who migrated from the European part of Russia and the Western Europe, mostly from Germany. In the center of Vladivostok, a continuous construction of buildings in the European architectural style was started [12]. There is an interesting comment by Professor of Washington State University (Pullman City) B. Ingemanson, " At that time, Vladivostok was a thriving international center. The proximity of vast natural resources, a large convenient port, and the railway contributed to the development of trade, flourishing of astounding architecture and significant recovery of industry"[13, 14] (Fig. 3).

Between the Russian Black Sea ports and Vladivostok, ships sailed carrying migrants and goods, then the construction of the Trans-Siberian railway was completed. The domestic architectural idea is part of the European-wide spiritual culture and the flow of culture from West to the East, reaching the Far East of the Asian continent, informed of the trends of the Western architecture.

Regular communication between Vladivostok with its status as "Porto Franco" and other ports gave a communications system to the international trade, due to which the city began to grow. 


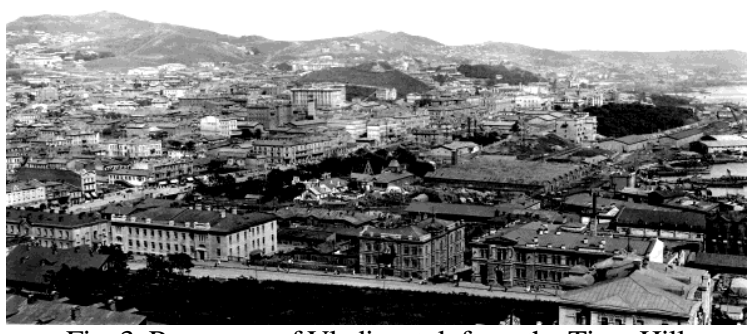

Fig. 3. Panorama of Vladivostok from the Tiger Hill, 1919-1920 [Source: from Ancha et al., 2009]

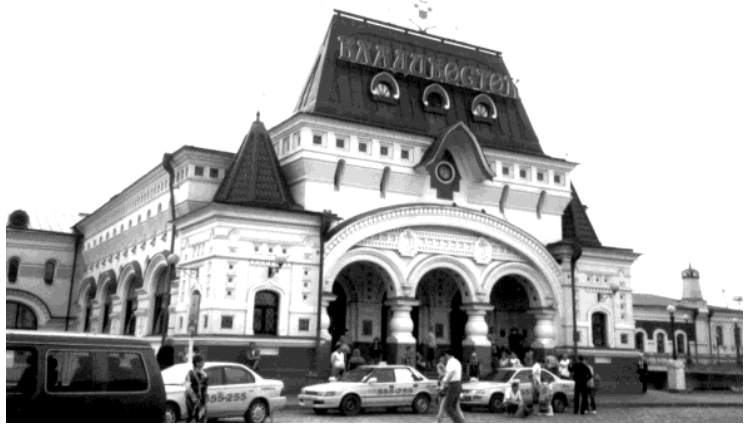

Fig. 4. Railway station in Vladivostok (1909-1911) [Source: material from author private archive]

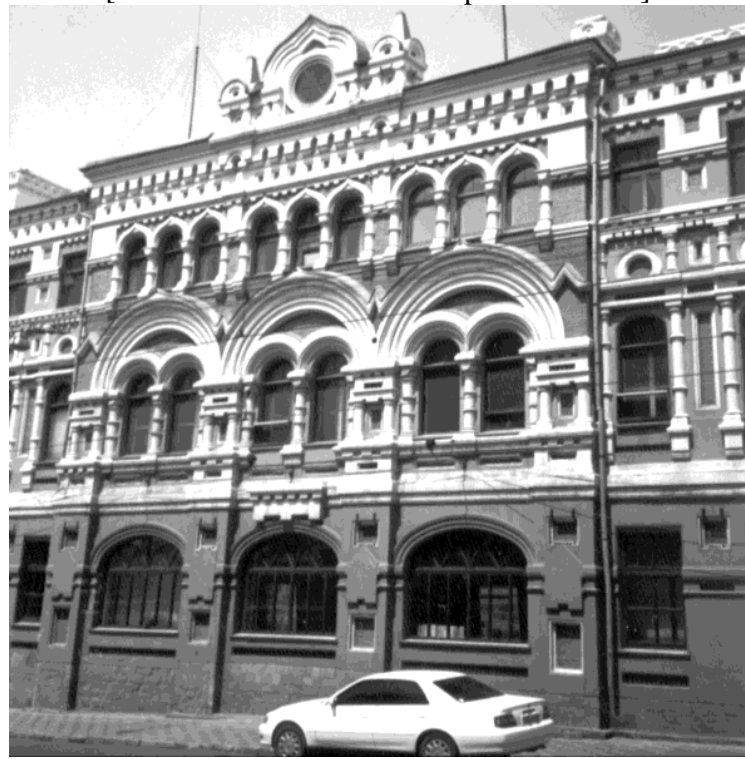

Fig. 5. Post Office building

(1900, the architect AA Gvozdziovsky)

[Source: material from author private archive]

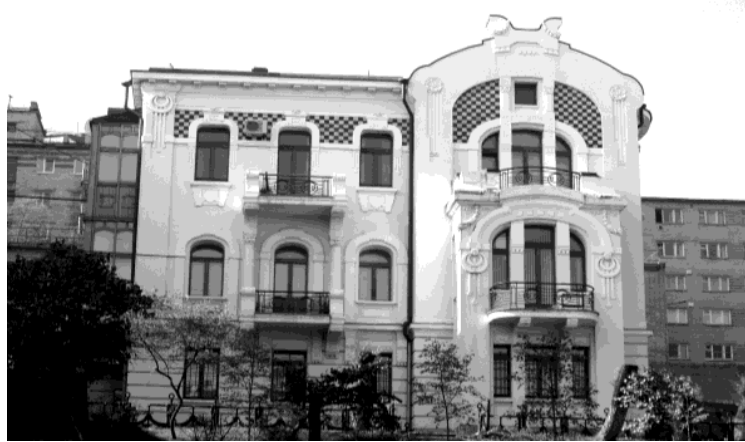

Fig. 6. Y.I. Briner's house (the architect G. Yunghendel) [Source: material from author private archive]
The trade links of Russia with China, Japan, and the United States rapidly developed. The status of Porto Franco attracted many representatives of the European traders and merchants of the first guild, such as de-Frieze, Kunst, Alberts, Demby, Cooper, Smith, Briner, Dattan, Lindgolm, and other entrepreneurs who were able not only to increase their fortune but also help the city in the development of navigation, the construction of the harbor with moorings and docks, city-building, and municipal improvements.

Looking at the architecture in Vladivostok since its formation and short-lived prosperity in the early $20^{\text {th }}$ century, it can be noted for its eclecticism, among which it is possible to select classic motifs, the "brick" style, the Neo-Russian style and Art Nouveau (Fig. 4, 5, 6, 7). In the central part of the city, manifestations of the German Gothic style are highly visible. At the turn of the $19^{\text {th }} / 20^{\text {th }}$ century, other European countries were represented in Vladivostok by Swiss, Danish, British, and French entrepreneurs, constructing buildings of trading houses, firms, residential mansions in accordance with their aesthetic preferences and thus leaving impact on the creation of an architectural image of the historic center of the city.

In the early $20^{\text {th }}$ century, the City Council banned the construction of wooden houses in the city center, as it was done in St. Petersburg, Moscow, and provincial cities. In the center of Vladivostok, solid construction of buildings on both sides of the streets in the style of the European architecture was carried out and not in the style of the Eastern architecture of such nearby countries as China, Korea, Japan. Many interesting wooden buildings, created in the late $19^{\text {th }}$ and early $20^{\text {th }}$ centuries, including in the style of Art Nouveau, unfortunately, were lost during the $20^{\text {th }}$ century. However, some buildings have survived to the present time.

The "face" of Vladivostok is turned to the sea. The sea and the picturesque mountainous landscape, "Hills of Manchuria", blocks of houses scattered on the slopes, give the city unique peculiarities, defining the shape of the city-fortress. The main facades of the historic center, located on the spurs of hills of the Eagle's Nest (the name is the same as in Port Arthur), are facing the south, to the Golden Horn Bay, or to the west, to Amur Bay.

In addition to urban mansions, separate holiday homes and other buildings for businessmen in Vladivostok stood out with interesting architecture and organic location in the natural landscape. The suburbs of Vladivostok were used as holiday suburbs. The distinctive feature of the prerevolutionary estates and dachas in the vicinity of Vladivostok was their location by the sea or in the 


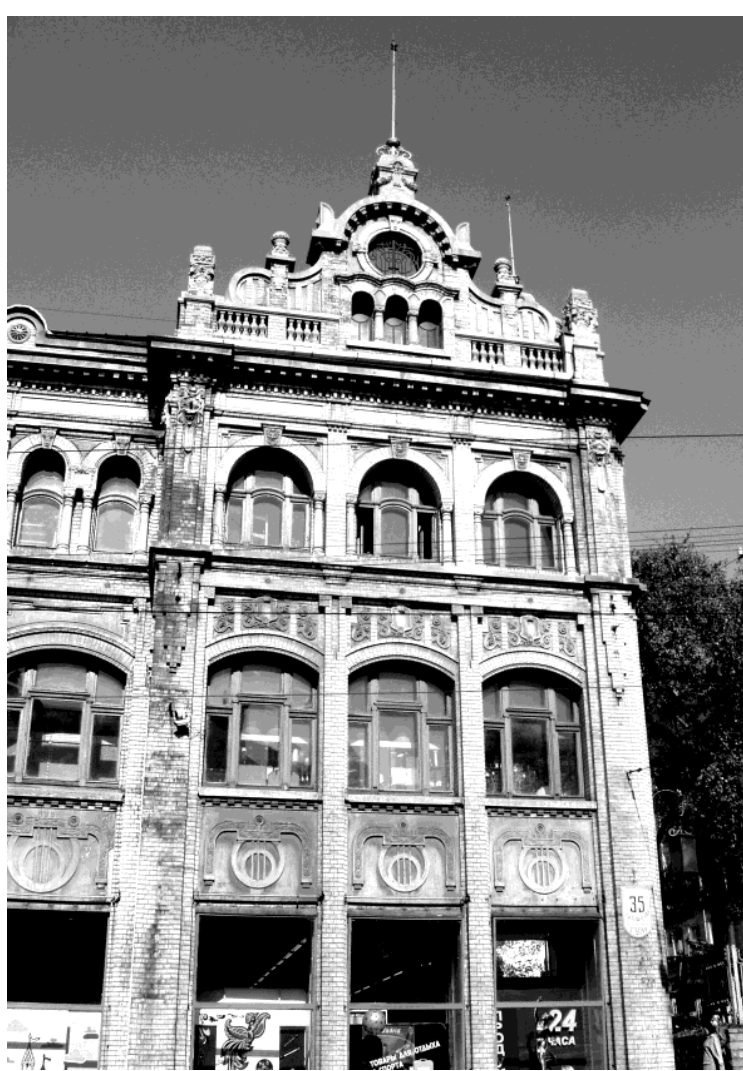

Fig. 7. The building of the Firm "Kunst and Albers" (the architect G. Yunghendel)

[Source: material from author private archive]

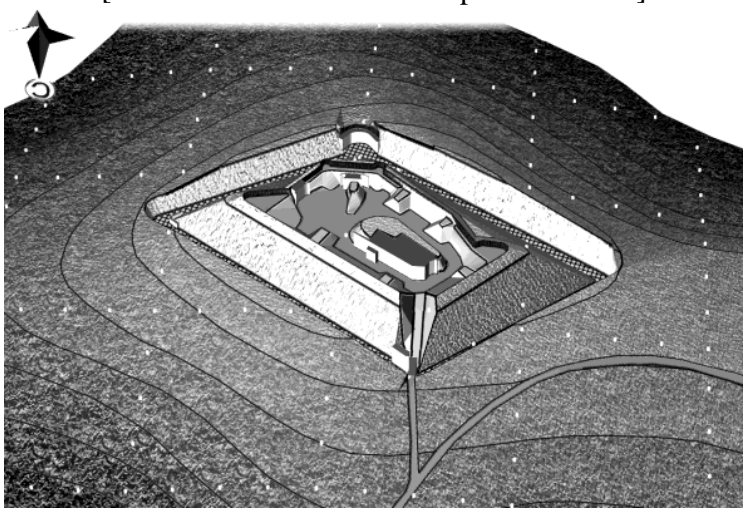

Fig. 8. Three-dimensional computer model of the Pospelov' Fort (Russky Island), project of 1899

[Source: material from author private archive]

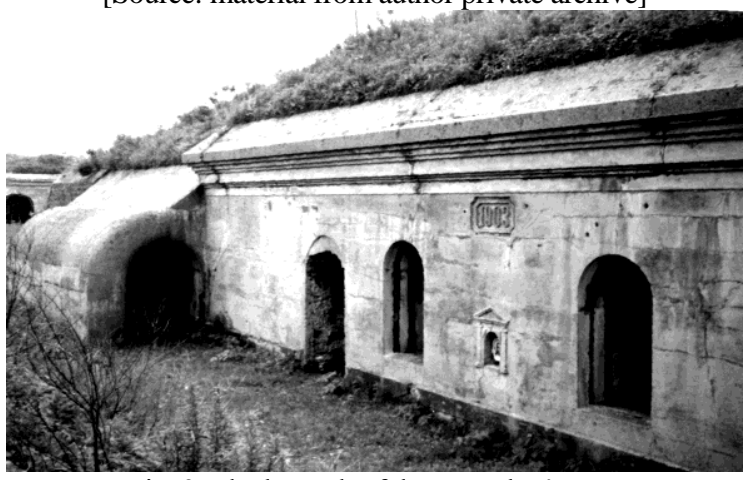

Fig. 9. The barrack of the Pospelov's Fort [Source: material from author private archive] immediate vicinity of the coast, surrounded by the picturesque natural landscape [15].

A decisive role in the urban planning was played by the construction of a grandiose complex of the Vladivostok Fortress [11, 16, 17].

By the early $20^{\text {th }}$ century, Vladivostok was reliving a construction boom; "on land across the Muravyov-Amursky Peninsula, on the hills in the city, on the coastal cliffs and islands - everywhere trees were uprooted, drilling, blowing up everywhere, bricks were laid and concreting everywhere as well; "the forts and batteries changed the overall picture of the city, from the romantic natural harbor it turned into a port worthy of its name" [18, 223-224].

As in Port Arthur, the author of the project of the long-term land by-pass in 1899 was C. I. Velichko. The project was approved on January 12, 1900, by Emperor Nicholas II. According to this project, in the early years of the $20^{\text {th }}$ century, forts and a number of other ground fortifications and redoubts were built in Vladivostok [8]. On average, the size of each fort is almost $200 \times 300$ meters, the area of the plot, bounded by a perimeter of the fortification is almost 4 hectares. The thickness of the walls and fortifications of the fortifications reaches approximately $0.9-1.2 \mathrm{~m}$. Most forts and fortifications are resolved as almost regular polygons surrounded by protective ditches in the perimeter (Fig. 8). Typical design is characteristic, many constituent parts of the forts on the different fortifications are almost identical, internal spaces isolated from each other are typical. Concrete casemate-like barracks serve as the centers of the compact compositions of the fortifications (Fig. 9), where in the design elements of the decor are used, borrowed from civil architecture; similar motifs are applied in the design of the caponier to roll-out arms (Fig. 10). To a large extent, the similarity of the fortresses of Port Arthur and Vladivostok is manifested in the concrete coastal artillery batteries, built at the turn of $19^{\text {th }} / 20^{\text {th }}$ centuries. The expressive exterior solutions and small, isolated interior with vaulted ceilings are typical.

The development of the city, remaining inside the ring of the fortifications and initially implemented as traditional orthogonal network blocks, by the early $20^{\text {th }}$ century became freer and more scenic, in accordance with the naturally rugged terrain. The diameter of the fortress is more than 10 kilometers, allowing to freely plan blocks of the city, extending to $4-5 \mathrm{~km}$. Closer to the wellfortified perimeter mostly barracks (Fig. 11) and other supporting constructions of the emerging fortress were constructed. 


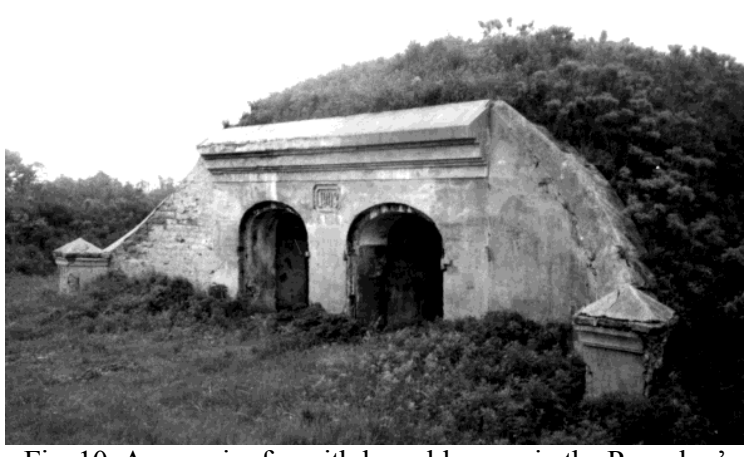

Fig. 10. A caponier for withdrawable guns in the Pospelov'

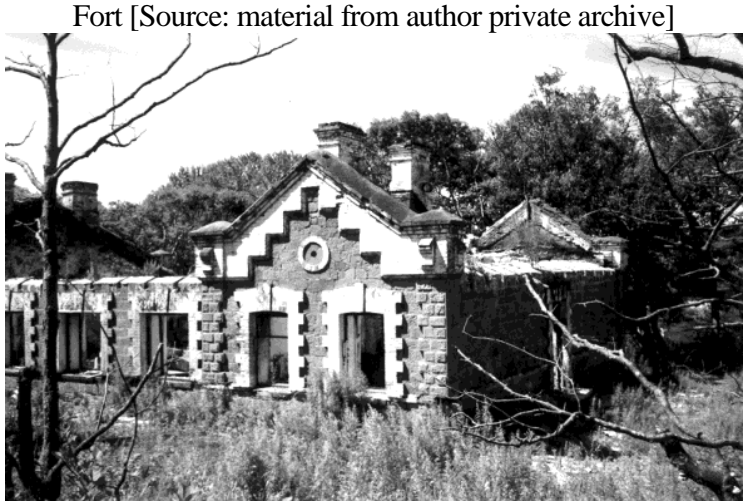

Fig. 11. A barrack (Russky Island)

[Source: material from author private archive]

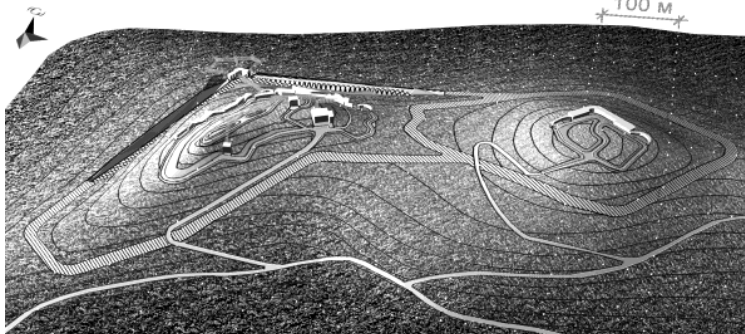

Fig. 12. Three-dimensional computer model of the fort № 7 with reference to the relief (Project of 1910)

[Source: material from author private archive]

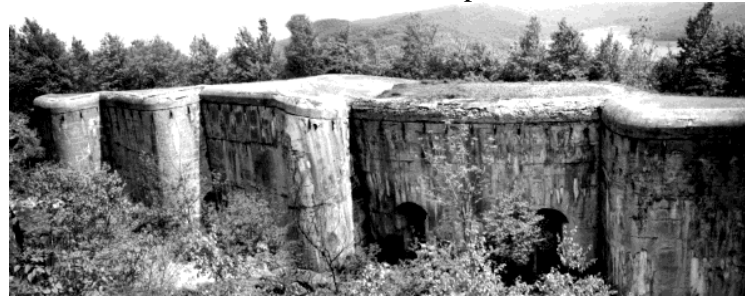

Fig. 13. Double coffer in the fort № 6

[Source: material from author private archive]

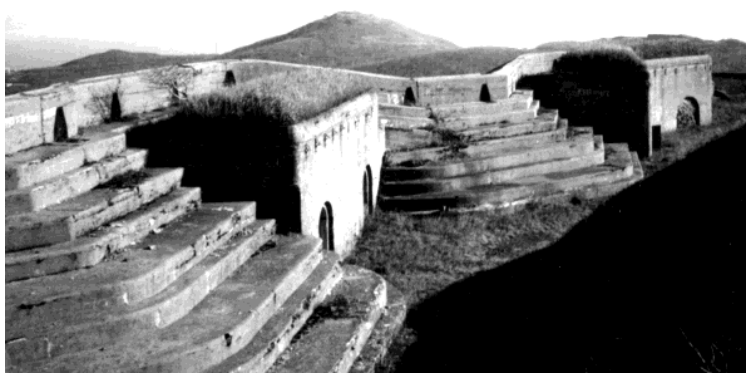

Fig. 14. A fragment of the parapet in the fort № 4

[Source: material from author private archive]
The fall of Port Arthur showed the need for the construction of a new type of fortifications to protect Vladivostok from land and sea. It became possible to create a grandiose and expensive project for strengthening defense of the fortress in 1910 . Military engineers have built a project on strengthening the defense of the fortress, Utopian in its grandiosity. Implementation of the project in 1910 was estimated at 98 million imperial roubles; even in 1915, during the First World War, almost 14 million roubles were awarded, while the construction of the fortress Port Arthur amounted to 4.25 million roubles $[19,20]$. The size of the land bypass of the fortress in diameter rose up to 24-26 $\mathrm{km}$. In 1910-1916 under the project, developed in the leadership of Engineer-General A. P. Vernander, the forts No. 1-7 were constructed on the southern border of the Sedanka River, the forts No. 9-12 on the Russian Island and other fortifications. These fortifications include casemate-like and underground structures; thickness of the concrete covers reaches 2.4-3.6 m. The constructions of the Vladivostok Fortress include the aggregate of 11 concrete forts, 9 defense points, about 50 artillery batteries and coastal caponiers. During the construction of the Vladivostok Fortress, it was expected to implement about $500000 \mathrm{~m}^{3}$ concrete and about $60 \%$ concrete works [3, 21].

The magnitude of the new challenges led to the technical impossibility of performance of the project in the framework of the previous principles, the layout of the huge area of forts on the tops of the steep hills was forced to be determined by the terrain, obeying it (Fig. 12). Physically enlarging, the dimensions of the fortifications became relatively smaller to the total area of the fortress. The size of each fort was approximately 300-700 meters, the average area of the plot, bounded by the perimeter of the fortification exceeds 13 hectares. The thickness of the walls and covers has increased two or three times. An asymmetric, complex spatial organization of the fortifications, due to their binding to relief, is characteristic. A vast and extensive internal communication space of the corridor type binds individual fortification of the fort, scattered on its surface and remote from each other. These small underground towns, capable of autonomous existence during the siege, are located under a group of separately standing buildings (coffres, Fig. 13, barracks, caponiers, concrete parapets with internal galleries, Fig. 14). The principle of construction of each fort has its own vector thrust, the central core of the composition of the forts, as in the project of 1899, serve as their barracks. The spaces had different functions: residential barracks, coffres and caponiers - martial, internal galleries served as shelters, places of worship were spaces near kiots with icons, etc.. 


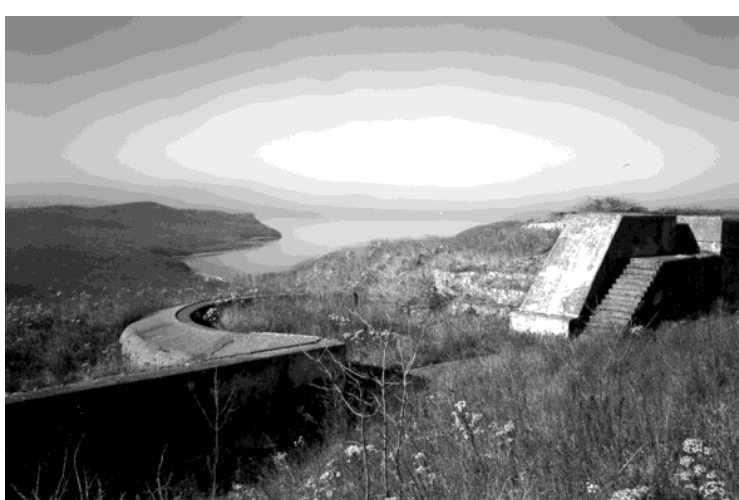

Fig. 15. The view from the fort № 9 (Russky Island) to the Gulf of Peter the Great

[Source: material from author private archive]

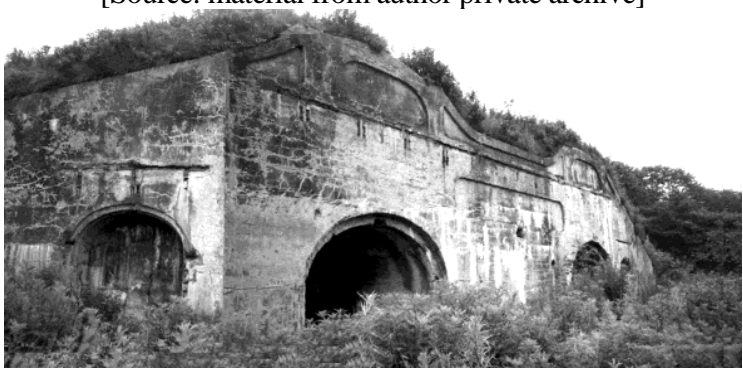

Fig. 16. A coast caponier for withdrawable guns (Russky Island)

[Source: material from author private archive]

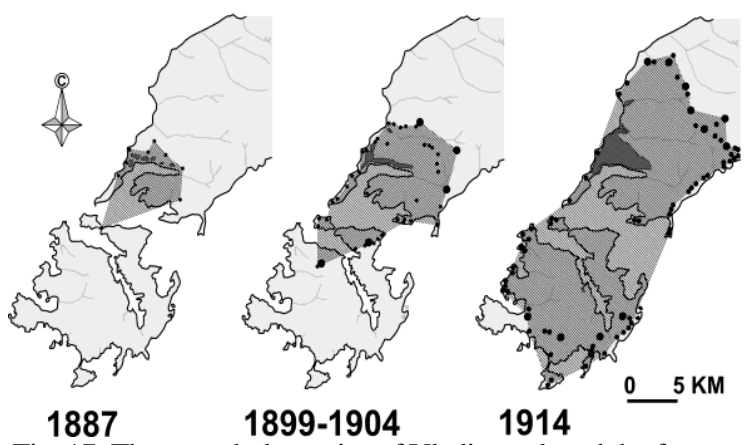

Fig. 17. The growth dynamics of Vladivostok and the fortress on the Muravyov-Amursky' peninsula and the Russky Island

[Source: material from author private archive]

The new fortifications have different proportions, their walls and covers are much more massive and often feature additional stone. The new coastal batteries differ by more than simple exterior solutions, their entrances are covered by knee-type vestibules. The massive walls and covers are significantly increased, covered by the earth, most of the inner spaces are connected by communications galleries, penetrating the concrete array of batteries along its entire length.

The fortifications were from cast-in-place concrete, internal galleries, niches for shooters and armored turrets were built in. The architecture was more and more "buried" under the ground, the internal spaces connected among themselves were increased. The facades of the fortifications facing the rear are hidden in the folds of the terrain. Near the buildings hidden under slopes, overgrown with shrubs and grass, as the exterior, there were only individual facades left. A general trend towards minimizing of the exteriors of relatively extensive multi-level, interconnected with each other interior spaces is characteristic. This approach has had a direct impact on the entire look of the buildings, very substantially changing their composition and proportions, exteriors and interiors. There were qualitative, topological changes and the transformation of the morphology of the fortifications. The constructions of the fortress visually demonstrate the plastic possibilities of the concrete casting with unified work of all elements of the structure with the new architecture without a clear division into the load bearing parts and loads being carried parts. The massive forms were created in the organic unity with the surrounding landscape (Fig. 15). The landscape and spatial organization of maritime fortresses are directly linked to the rugged terrain of the coast, which is typical of terrain with high cliffs, deep coves, and capes. This explains many features of the architecture of such seaside fortresses, built of which are similar to the fortifications, erected in the mountains. The complex three-dimensional compositions of the fortifications, correlated with the outlines of the natural topography, represent the current architecture and landscape environment. The originality of the architecture of fortresses of this period is associated with the transition from the building of brick and stone structures to the creation of sophisticated complexes of monolithic concrete. The visually nonfunctional prints of selected popular architectural styles of these times on the facades of some fortification building are characteristic as well (Fig. 16). The fortifications bear the features of the original Art Nouveau and, partly, the traditional classical style.

The names of the forts of the Vladivostok Fortress symbolized the historical continuity and the indissoluble link of Vladivostok with the Russian Empire (such as the forts of Prince Rurik, Prince Oleg, Saint Grand Prince Vladimir, Grand Prince Dmitry Donskoy, Tsar Ivan the Terrible, Emperor Peter the Great, Empress Catherine the Great, Emperor Alexander the Blessed, Emperor Alexander the Liberator, Heir Tsarevich Alexei Nikolayevich).

Around the military settlement, the sphere of services and social infrastructure was emerging [22]. The growing city absorbed many of the old fortifications, its boundaries extended under the protection of the fortress, the road and street system developed. Vladivostok is now under the protection of two rings of fortifications (Fig. 17). The railway branches were built, the system of suspended cable roads, electricity, and drainage systems were created, a wireless telegraph operated. Airfields with hangars for aerostats and airplanes were 
built. The road system of the fortress emerged and improved which now connect many districts of the modern city. In 1908, the water supply scheme was developed for the fortress, later having an influence on the development of Vladivostok. As in Port Arthur, in Vladivostok, there are holiday areas outside the fortress, located in the forest and the coastal areas, mainly, to the northwest of the city.

With the development of the city, the system of its fortifications provided a considerable mutual influence on each other, growing consistently until the early $20^{\text {th }}$ century. Therefore, the fortress of Vladivostok is an integral part of the present city environment.

The beginning of World War I, the following Civil War, and the events of 1917 resulted in a giant construction which, sometimes almost concluded, was frozen. In 1918, there was the intervention of Vladivostok by American and Japanese armed forces. The latest fortifications were in foreign hands. It is known that the interveners praised the Vladivostok fortresses this way, "This fortress is the best maritime fortress around the world, and its fortifications are themselves are positively a miracle of military and engineering art" [20].

In the $20^{\text {th }}$ century, Vladivostok has passed specific stages in the development of architecture in the Soviet period - constructivism and moving to the pompous and representative Stalinist architecture that resulted in emerging of the most distant from the capital "Stalin Empire Style" on the shore of the Pacific Ocean. Sad pages in the life of the city of the 1930s are associated with expulsion camps from which prisoners by ships were sent to Magadan, Kolyma, and Chukotka.

Throughout its history, Vladivostok repeatedly became the Russian polygon for implementation of the ambitious urban development plans. Currently, the new city's development program is implemented with the domestication of the adjacent island areas and the construction of large-span bridges of various designs. The dimensions of the bridges are characterized by values such as the span length up to $1104 \mathrm{~m}$, the height of the pylon - up to $320 \mathrm{~m}$ and the total length of the flyover - up to $3100 \mathrm{~m}$. In fact, many large-scale ideas of the 1930s-1950s revived at a new level for the development of Vladivostok. This is due to the Forum of the countries of the Asiatic-Pacific region held in September 2012 and it gives a new, positive impetus to the development of the entire Far East region and Vladivostok, the remaining the outpost of Russia in the Pacific Ocean.

The expansion, carried out by the Russian Empire, extending to the East, culminated in the $20^{\text {th }}$ century. The fortress Port Arthur was one ring of forts and shore batteries around the city corresponding with the coastal mountainous landscape. In Vladivostok, we have also implemented the scheme of the emerging of the city and fortresses in the rigid dependence on the structure of the terrain where the boundaries of the protected perimeter were identified by the local geomorphology, and the fortifications were located on the tops of hills for better control over the terrain. These are the basic principles of the urban development of Port Arthur and Vladivostok. The fortress of Vladivostok under the draft of 1899 is very close to Port Arthur's spiritual ideas, implemented in the first years of the $20^{\text {th }}$ century. After the fall of Port Arthur, Vladivostok began to intensively fortified, and here there was a second ring of fortifications, which still far exceeds the size of the modern city. The giant fortress of Vladivostok was the last marine fortress built by the Russian Empire but remained unfinished and turned into a Utopia. The existing fortifications of the Vladivostok Fortress are declared a monument of history and militarydefensive architecture of federal significance.

The main factor in the form creation of fortresses has always been their function but the architectural solutions were determined by the technical and technological techniques used to create the fortress. The turbulent processes of the turn of the centuries, the replacement of the defensive paradigm, construction, and architectural concepts, and aesthetic views, innovations of that time - all this was reflected in the architectural appearance of the marine fortresses. Features of the architecture are due to the fusion of features defined by its function, the complexity of the terrain, the applied technological solutions, architectural traditions, and innovations. The traditions that were characterized, first of all, by the use of elements of stylistics and decor, widely used in civil architecture, disappeared and gave way to work with large masses and volumes which became actively used means of artistic expresion and gave rise to new architectural solutions. The technological effectiveness, functionality, and rationality of solutions, manifested in the architectural rigor of the forms of fortresses of this period, increased.

The concrete defensive architecture of the late $19^{\text {th }}$ - early $20^{\text {th }}$ centuries became a special architectural phenomenon and the last link in the centuries-old evolution of fortresses. For several years, there has been a rapid transition from compact compositions in the form of regular polygons with small buildings, which include isolated inner spaces, to extensive and complex asymmetric complexes with a vector orientation of plans, large architectural masses and volumes, with a tendency to minimize exteriors and the development of extended multi-level, connecting internal spaces. Difficult in their spatial organization, cast from concrete, the new fortifications with their vanishing exterior and branched internal structure marked the end of the era of fortress construction. 


\section{References}

1. Сивов Е.В. Из истории Николаевска-на-Амуре (1850-1917 гг.). Ленинское знамя, 1963, с. 82-97.

2. Горнова М.И. Крепость на мысе Чныррах. Памятники Отечества, 1984, № 2(10), с. 80-83.

3. Яковлев В.В. Приморские крепости. Отдел курса «Береговая оборона» Военно-морского факультета Военно морской академии Р.-К.К.Ф. Ленинград: Издание военно-морской академии Р.-К. К.Ф., 1926. 247 с.

4. Яковлев В.В. История крепостей. Санкт-Петербург: Полигон, 1995. 397 с.

5. Крадин Н.П. Дальний (Далян) город европейского типа на востоке Азии. Архитектурное наследство, 2003, № 45, c. 162-173.

6. Левошко С.С. Город Дальний в истории российского градостроительства в Маньчжурии. Россия и ATP, 2000, № 4, c. 96-107.

7. Порт-Артур. Воспоминания участников. Нью-Йорк: Издательство им. Чехова (Chekhov Publishing House of the East European Fund, Inc.), 1955. 412 c.

8. Аюшин Н.Б., Калинин В.И., Воробьев С.А., Гаврилкин Н.В. Владивостокская крепость. Владивосток: Дальнаука, 2006. 336 с.

9. Касьянов Н.В. Крепость Владивосток - памятник Российского военно-оборонительного зодчества конца XIX и начала XX века. Архитектурное наследство, Москва: Editorial URSS, 2006, Выпуск 46, с. 269-288.

10. Марков В. М. Путеводитель по Владивостоку. Владивосток: Дальневосточное книжное издательство, 1993. $240 \mathrm{c}$.

11. Касьянов Н.В. Владивостокская крепость. Между прошльмм и будущии. Владивосток: ДВГТУ, 2001. 100 с.

12. Памятники истории и культуры Приморского края. Материалы к своду. Владивосток: Институт истории ДВО РАН, 1991. $268 \mathrm{c}$.

13. Ингемансон Б. Потерянный рай. Имение Новогеоргиевское, 1892-1922. Россия и АТР, 2001, № 4, с. 23.

14. Анча А.А., Калинин В.И., Позняк Т.З. Владивосток в фотографиях Меррилла Хаскелла. 11 августа 1919 23 февраля 1920. Хабаровск: Риотип, 2009, с. 14.

15. Касьянов Н.В. Приморские имения в окрестностях Владивостока на рубеже XIX-XX веков. Русская усадьба, 2005, Выпуск 11 (27), с. 271-286.

16. Обертас В.А. Формирование планировочной структуры Владивостока в XIX в. Архитектурное наследство, 1976, № 25, c. 85-93.

17. Касьянов Н.В. Владивостокская крепость: архитектурно-исторический аспект. Вестник ДВО РАН, 2002, № 1, c. $72-84$.

18. Деег Л. Кунст и Альберс. Владивосток. История немеикого торгового дома на российском Дальнем Востоке (1864-1924). Владивосток, Издательство Приморского полиграфкомбината, 2002.

19. Ргвиа, Ф. 802, Оп. 5, Д. 16816, Л. 143.

20. Яковлев В.В. Фортификация. Вып. III, Устройство крепостей в начале ХХ столетия; участие их в мировой войне и современное положение вопроса о них. Ленинград.: Издание Военно-Инженерной академии РККА, 1925. $216 \mathrm{c}$.

21. Ргвиа, Ф. 802, Оп. 5, Д. 16816.

22. Обертас В.А. Формирование планировочной структуры Владивостока в XIX в. Архитектурное наследство, 1976, № 25, c. 85-93.

INFORMATION ABOUT THE AUTHOR:

Kasyanov Nikolay Vladimirovich. Born in 1973, Leningrad. Educational background: 1993-1999 Architectural Institute of the Far Eastern State Technical University (Arch IDVGTU), now part of the Far Eastern Federal University), diploma with honors. 1999-2002 the postgraduate program. Since $2004-$ a candidate of architecture. Employment: 1999-2004 the teaching staff, Arch DVGTU, Vladivostok. Since 2004 - Senior Research Fellow, Scientific Research Institute of Theory of Architecture and Urban Planning (NIITIAG), Moscow. Since 2006 - Head of Lab of Architectural Form Creation, NIITIAG. The author of more than 50 published works, with experience of design works.

Scientific interests: form creation in architecture and nature, innovative technologies in architecture, fortress architecture. 105264 Moscow, ул. 7-я Парковая, д. 21-a, tel/fax 8 (495) 9650255 , phone 891513879 72, E-mail: kas_nv@mail.ru

Kopsavilkums. Militāra rakstura nocietinājumi pasaules pilsētbūvniecības vēsturē ienesa jaunu būvniecības tehnologiju un arhitektūras formveides izteiksmi. 19. gs. beigās krievu militārā padome nonāca pie secinājuma, ka tradicionālā ķieǵel̦u mūru nocietinājumiem nav tik lielas noturības, kā tas ir raksturīgs monolītā betona mūrim. Krievijas impērijai piederēja vairākas pilsētas ar piekrastes nocietinājumiem pie Baltijas jūras, Melnās jūras un Klusajā okeānā. Gar Klusā okeāna piekrasti nocietinājumi bija Ohotskas, Petropavlovskas-Kamčatkas, Nikolajevas pie Amūras, Vladivostokas, Arturas ostām, kas liecināja par ḷoti nopietnu valsts militārās varen̄ibas attīstîbu. Tālākais nocietinājuma punkts austrumos bija neaizsalstošā Arturas osta. Tās būvniecības plāns1898. g. paredzēja ostas pilsētas-nocietinājumu izvietot kalnainā vietā ap $200 \mathrm{~m}$ v. j. līmeņa, tai pievienojot $70 \mathrm{~km}$ sasaisti ar sauszemes ceļu un izvietojot ne mazāk par 70 tūkst. vīru lielu karaspēku. 1904. g. bija izbūvēta jau puse no pilsētas nocietinājuma. 1904. gada beigās japāņu kara laikā cietoksnis tika ieņemts. Attīstoties kug̣niecībai un tirdzniecības Tālo Austrumu zemēs, strauju izaugsmi 
aizsāka netālā dienvidrietumu daḷas osta - Vladivostoka. Pilsēta jau 19.gs. beigās bija pārmantojusi Eiropas kultūras tendences, kuru aktīvi ienesa krievu militārā vadība, arhitekti, vairāki vācu būvinženieri. Aktīva kuğniecība un tirdzniecība ar Japānu, K̦īnu un Ameriku nesa strauju Vladivostokas attīstību.

Jau 19.gs.beigās pilsētas apbūvē ir nolasāms dažādu arhitektūras stilu sajaukums, kas nācis līdz ar Vakareiropas tirgotāju un kuǵotāju apmešanos pilsētā - eklektika, klasicisms, ķieǵeḷu arhitektūra, modernisms. Pilsētas centrā vairāk dominē gotiskā stila tendences. 20.gs. sāk. pilsētā aizsākas nocietinājumu būvniecība, kur katra forta lielums ir aptuveni 200x300 m, bet aizsargsienas biezums sasniedza 0.9-1.2 m. Nocietinājumu iekšpusē ir izvietojusies pilsētas apbūves kvartāli. Tuvāk nocietinājumu perimetram atradās kazarmas. 1910. gadā aizsākās nocietinājumu pastiprināšana, mūrus uzbiezinot pat 2-3 reizes. Katrā no milzu būvapjomiem atradās galerijas un kaujas nišas. Nocietinājumu līnija tika slēpta aiz reljefa, kokiem, zālienā, tikai vietām atsedzot mūra laukumu. Ap pilsētas militāro infrastruktūru gredzenveidā attīstījās tās apkalpojošā struktūra, tā pilsētai pamazām veidojot savu urbānās telpas raksturu. Līdz ar cariskās valdības gāšanu 1917. gadā noslēdzās militāro nocietinājumu būvniecības laiks Krievijā. 


\title{
Parallels and Analogies in the Interwar Architecture in Latvia and Czechoslovakia
}

\author{
Renāte Čaupale, Riga Technical University, Latvia University of Agriculture
}

\begin{abstract}
The interconnections of the interactions between the art and architecture of the Latvian and Czechoslovakian nations are relatively fragmented. However, there is one large European cultural space in which both parallels and analogies can be found, as required by the communicative role of art and architecture. In the 1920s and 1930s, a European architecture that was founded on modern features could be found in the architecture of the new Latvian state. Art Deco aesthetics was one of the operative events of the interwar period. Its expression changed along with the changes occurring during this time period, retaining the decorativeness principles of Art Deco. Art Deco aesthetics encompass several distinct but related design trends, including the following: interpretation of elements of folklore - Ansis Cīrulis in Latvia and Pavel Janák in Czechoslovakia authored masterfully designed interior examples. Regardless of their creative potential after the First Wold War, artists and architects in many new states were drawn into the stream of contemporary trends - the folkloristic style, which became one of the decisive sources of inspiration for demonstrating national self-determination, which, in turn, is typical of all cultures and civilisations and can sometimes be international. An analogous interpretation of folklore brings these processes together, which allows them to be identified as folkloristic Art Deco trends. There are moments when folkloristic Art Deco as a component of Modernism art and architecture of the 1920-30s organically foreshadows the aesthetics of pre-postmodernism; modernization of the classic form, which has been highlighted directly in the period of the leader cult common in new states. The wish to represent people's self-determination in architecture and the circumstances of this time shaped the monumentality of the masterpieces designed by Jože Plečnik and Eižens Laube in Prague and Jūrmala, respectively, and, at the same time, also their distinct consideration for national heritage. Naturally, a cultural basis that is identical for many European countries can be identified in Latvia and Czechoslovakia, rather than art elements of incidental nature that have randomly entered the country. For this reason, the aim of the present paper is to show the ideological context of Latvian and Czechoslovakian architecture.
\end{abstract}

Keywords: architectural history, the 1920s and 1930s, Art Deco, folkloristic art

\section{Introduction}

The interrelationships in art and architecture between the Latvian and Czechoslovakian nations are relatively fragmented. However, due to their existence within a single large European cultural space, both parallels and analogies can be identified, as defined by the communicative role of art and architecture.

In the 1920s and 30s, specific activities that were characteristic of Europe at that time could be identified within the architecture of the new Latvian state. The aesthetics of Art Deco was one of the most significant architectural and artistic ways of expression during the interwar period, which, although changing as time went by, still retained substantially unchanged principles of Art Deco ornamentation.

The aesthetics of Art Deco comprises a number of different yet mutually interrelated trends. Summarizing the views held by historians regarding US architecture, Eva Weber discusses three significant variants of the Art Deco style: the so-called Zig-zag style (also known as Zig-zag moderne), the conservative version of the 1920 s and 30s (Classical Moderne) and the Streamline
Moderne of the 1930s [30;19]. After the first World War, when news states including Latvia and Czechoslovakia appeared on the European map, efforts at seeking national forms of expression cannot ignored, thus another variant can be singled out, namely, folkloristic Art Deco, that in spite of the seeming different express in any country, "there is nevertheless a true, if hidden, unity, a secret synthesis, in our present civilization" [4].

\section{Latvian and Czech Architecture - Topicality of the Discussion}

Latvian architecture is mostly known in Europe for its outstanding Art Nouveau structures: this was further confirmed by the fact that in 1997, the Art Nouveau buildings in Riga were universally recognized as noteworthy treasures of European cultural heritage and was included in UNESCO's list of World Cultural Heritage. Naturally, Latvia has had historical creative connections with the Scandinavian countries. However, in the field of art, these connections mostly manifested themselves within the framework of national romanticism, with inspiration drawn from Finland. Finnish art and 
architecture influenced the creative work of Latvian architects most at the beginning of the 20th century.

Tender competitions show that there were successful professional relationships with Finland, Sweden and other countries. Architects from Germany, Switzerland, Finland and Poland took part in the tender for the design of the Riga Town Hall in 1897. In 1912, Finnish architect Eliel Saarinen proposed a design for the building of the Riga Craftsmen Society [17]. In 1909, Swedish architect Lars Johan Lehming submitted a design for a hotel in Riga [6]. In the 1930s, art historian Jānis Siliņš, when analysing the architecture exhibition at the City Art Museum that took place at the turn of 1934 and 1935, identified in the architecture both a visible 'Swedish influence' and 'along with it, a couple of American and French influences" [22]. However, this list of intercultural relationships is incomplete, because there are direct or indirect parallels between Latvian architecture and that of other countries as well, and "naturally, a cultural substrate identical to that of other European countries can be found rather than artistic elements of random nature of styles that have been swept in by chance" [23].

If we take a look at the architectural activities at the beginning of the 20th century, historical evidence can be found showing that young Czech architect František Roith, who was a student of Austrian architect Otto Wagner, took part in the tender for the design of the building of the Riga Latvian Theatre [32]. Roith, who had only worked as an independent architect for four years by 1911, proposed a design for a building that was a synthesis of Neoclassicism and early modernism, which was trendy at the time (Fig. 1a, 1b).

Roith implemented his large significant designs as late as after the First World War, in the 1920s and 30 s, when he had already become one of the representatives of the official architecture of Prague. Moreover, although the requirements put forward for the official representation of the time that were based on the classical tradition were met on the outside, Roith's creative work is described as a successful balance between the new monumentalism and the historical monumentality [7]. He was not afraid of introducing stylistic elements of Art Deco into interiors [25; 33.], for example, the geometrical ornaments on the overhead lighting, the walls, ceiling and windows of the stairwell designed according to Art Deco aesthetics, in the stunning hall of Prague City Library (1924-1928; Městská knihovna; Mariánské nám.1). Such light distribution in a hall, which was an innovation in Riga at the time, was implemented in the Large Hall of the University of Latvia in the 1930s (1931-1936),
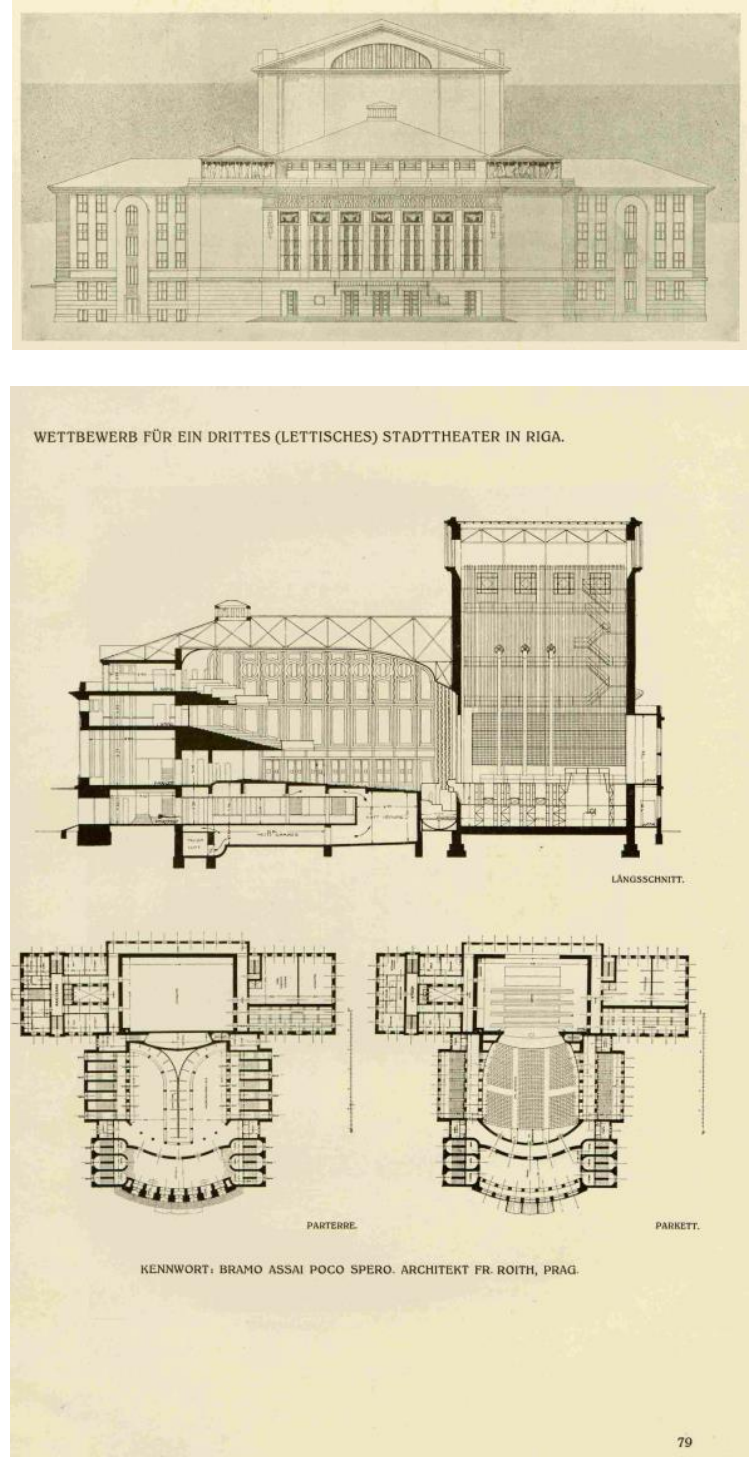

Fig. 1a, 1b. František Roith, propose a design by tender for Riga Latvian Theatre, 1911 [32]

architect Ernests Štālbergs); in 1933, architect Aleksandrs Klinklāvs designed the same thing in his project for the universal hall of the Riga Students' Building, which was never constructed [12].

František Roith designed the façade of the design proposed in 1911 for the Riga Latvian Theatre in accordance with the principles of composition that he would then later implement in his home city Prague in the 1920s: a serenely balanced façade that is divided by pilasters and has relatively large window apertures, which, in the design for the building in Riga, have also been divided by muntins. The large windows are the main accent of the façade, their fragility providing contrast to the bulkiness of the stonework surrounding the windows. One might admit that the 1911 design for Riga foreshadows Roith's future signature style. Ornaments as clearly and undoubtedly classical in style as those envisaged in the design for the 


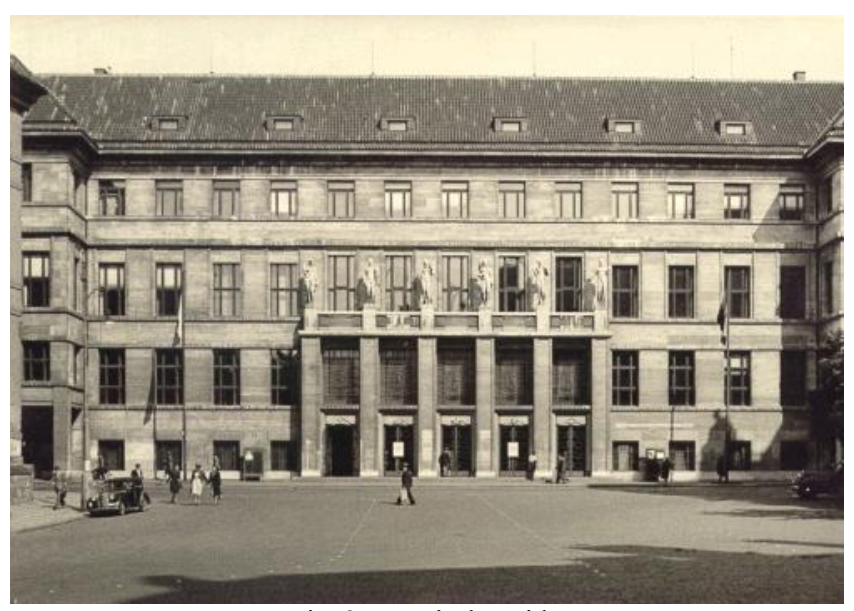

Fig. 2. František Roith,

Prague City Library (1924-1928) in 1947 [39]

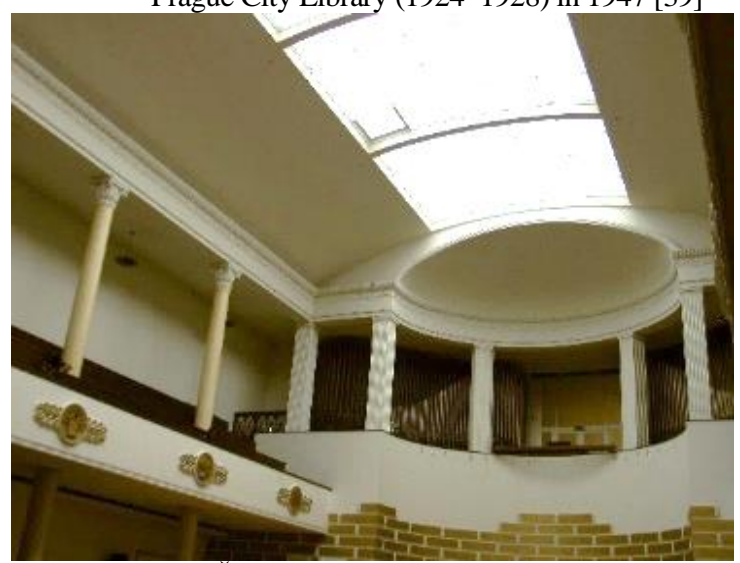

Fig. 4. Ernests Šâlbergs, Large Hall of the University of Latvia, 1931-1936 [46]

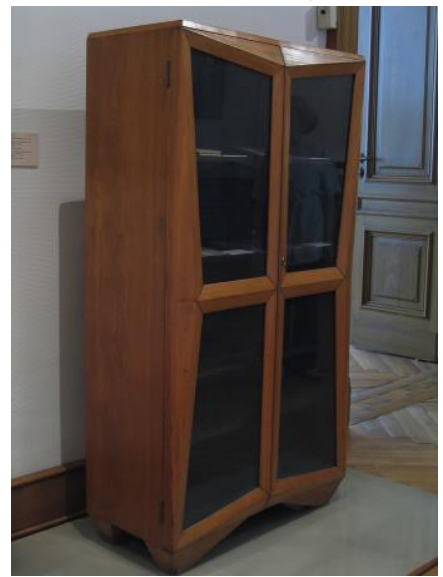

Fig. 6. Pavel Janák, bookcase, Czechoslovakia, 1912-1913 [37]

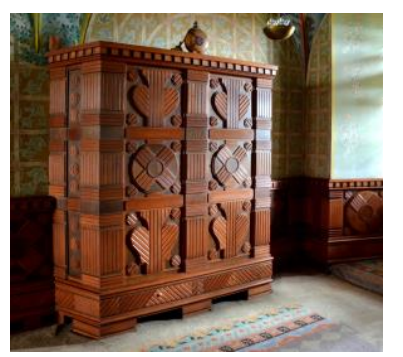

Fig. 9. Pavel Janák, the Star sign (Zverokruh) dining room, 1924, at the Renaissance and

Baroque Bartoň-Dobenín family palace (1501-1660) [38]

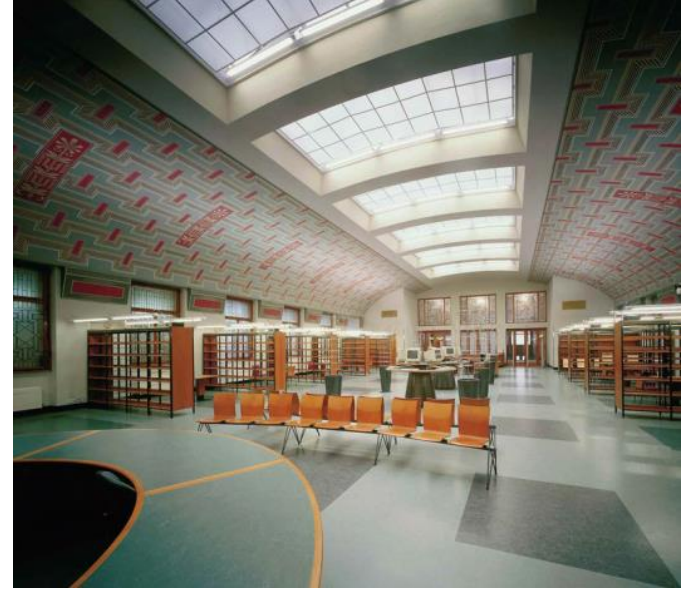

Fig. 3. František Roith, Prague City Library (1924-1928) hall after reconstruction in 1998 [33]

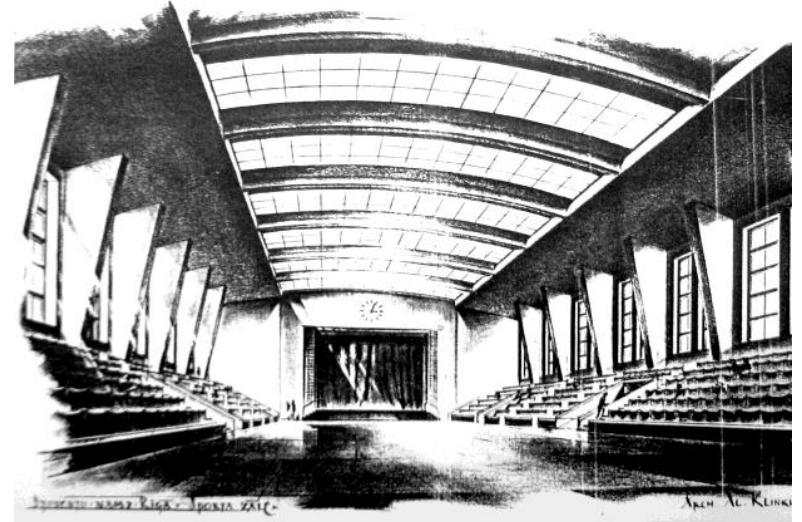

Fig. 5. Aleksandrs Klinklāvs, project proposal for the universal hall of the Riga Students' Building, 1933 [42]

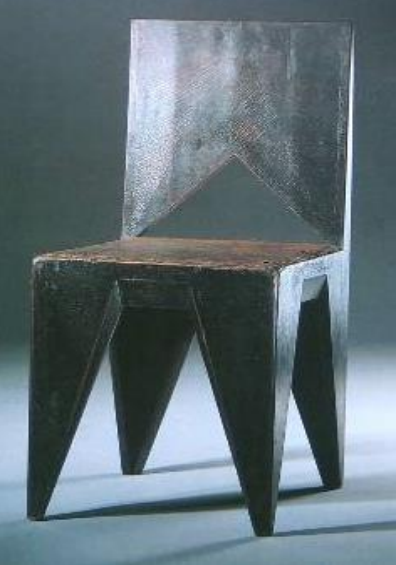

Fig. 7. Vlastislav Hofman, chair, Czechoslovakia,

1912-1913 [35]

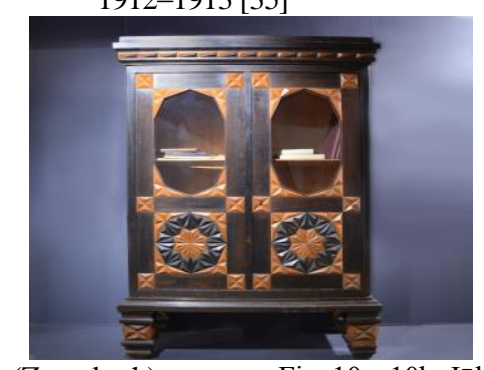

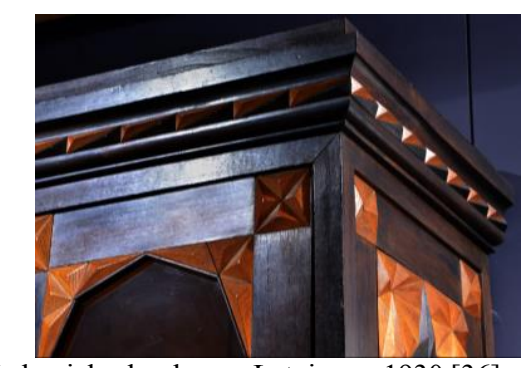

Fig. 10a, 10b. Jūlijs Madernieks, bookcase, Latvia, ca. 1930 [36]

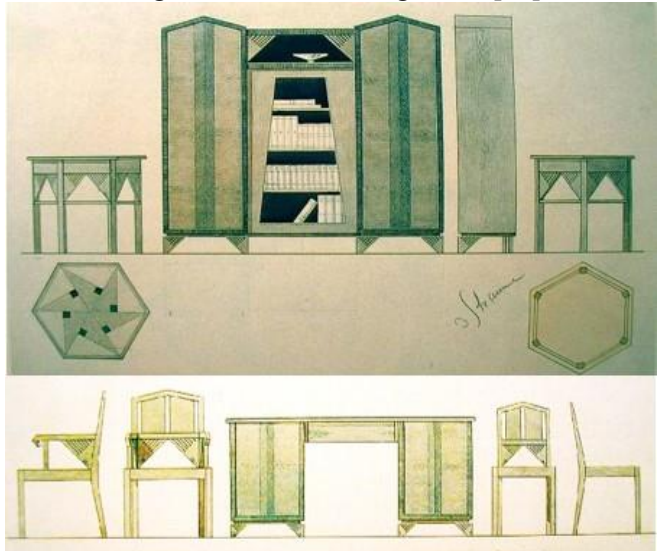

Fig. 8a, 8b. Jūlijs Straume, Latvia, ca. 1936 [40] 

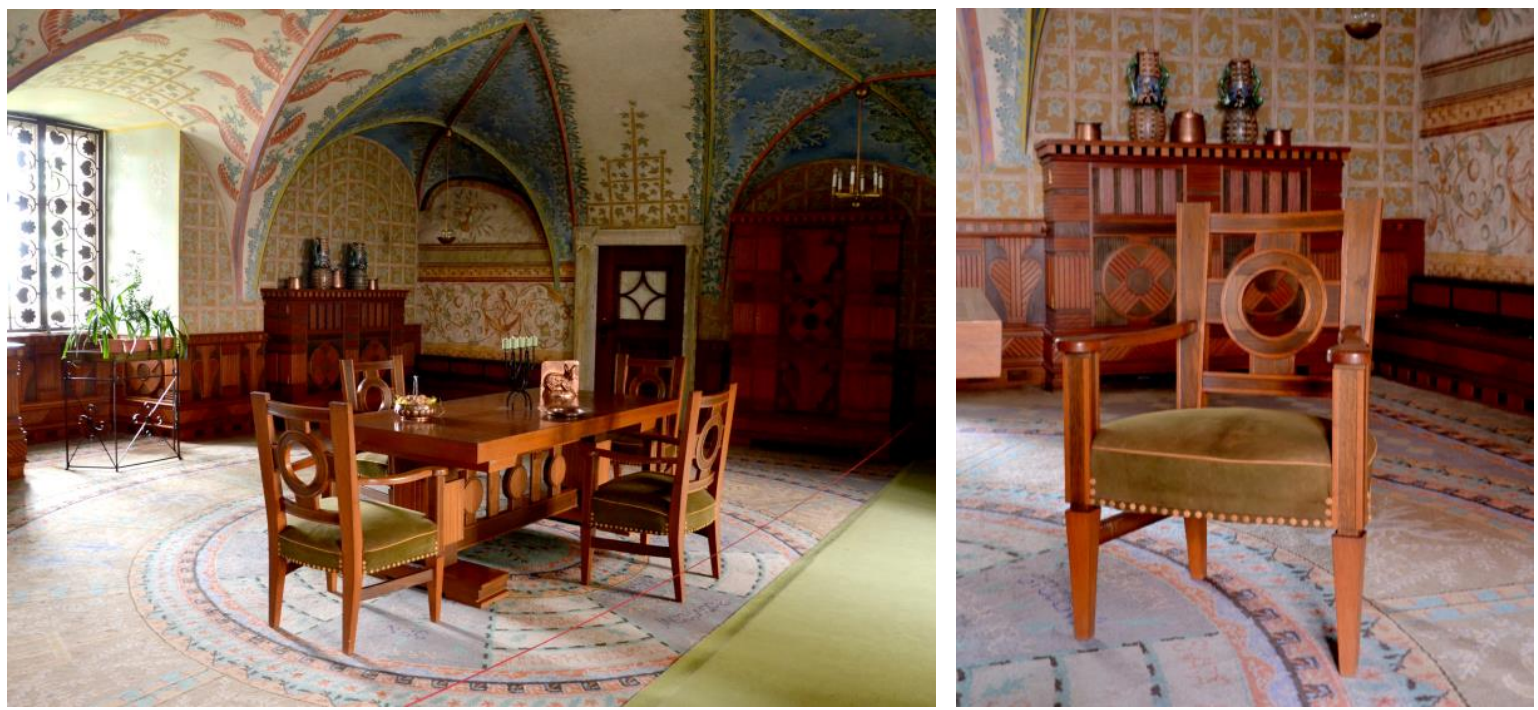

Fig. 11a, 11b. Pavel Janák, The Star sign (Zverokruh) dining room, 1924, at the Renaissance and Baroque Bartoň-Dobenín family palace (1501-1660), Nové Město nad Metují, Chech Republik [38]
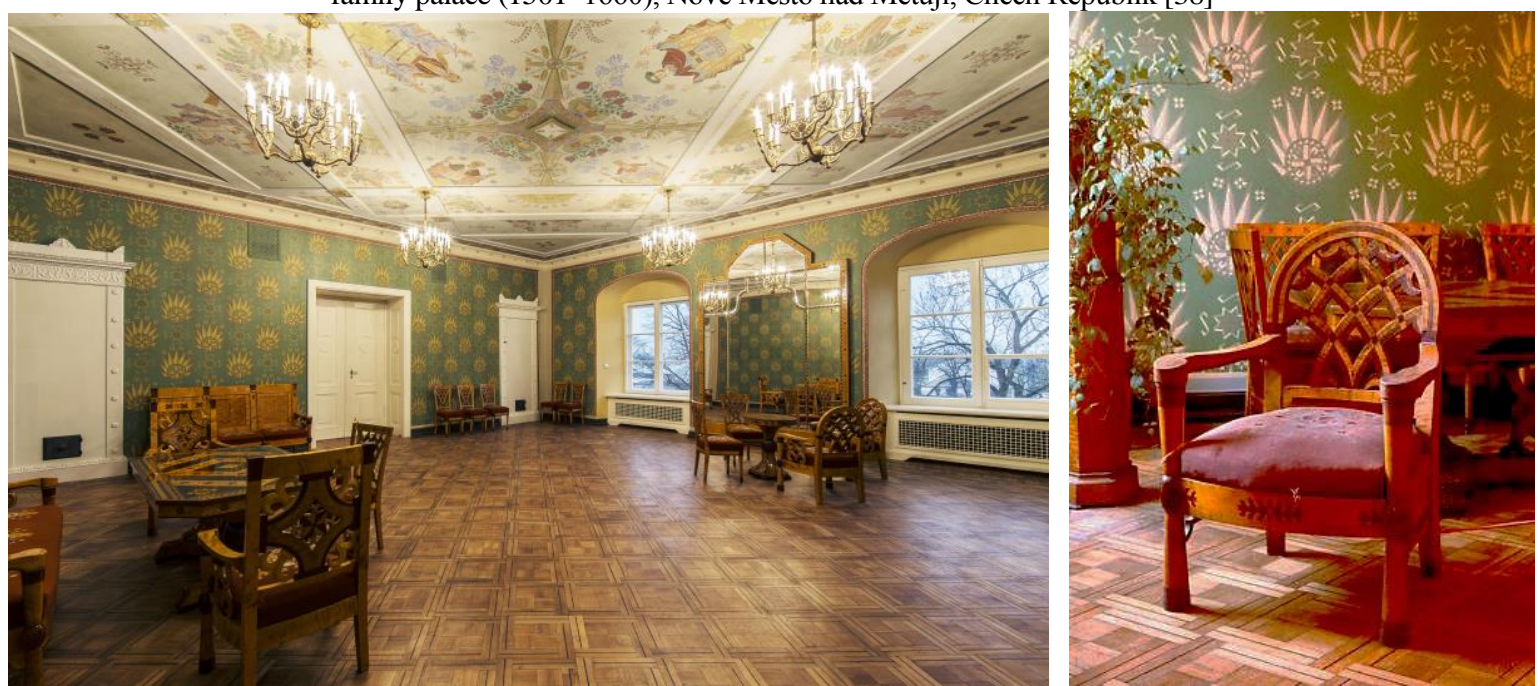

Fig. 12a, 12b. Ansis Cïrulis, The Ambassador Accreditation Hall, 1926-1929, at Riga Castle (1330-1515), Riga, Latvia [43]

building of the Riga Latvian Theatre would only later disappear from buildings designed by Roith, with the arrival of stronger modernist accents.

The trend among architects to transition from historicalized architecture to a geometrialization of forms can be clearly seen in Latvian architecture; however, only in the Czech Republic this trend blossomed into architectural Czech Cubism. In Western Europe, the transition to the geometric form and linear rhythm in architecture was initiated by Auguste Perret, Otto Wagner and Josef Hoffmann, the latter of which designed furniture with proportion-wise elaborate shapes made of straight lines as early as in 1900 , in a similar way to that of Scottish architect Charles Rennie Mackintosh. The trend among architects to simplify forms to basic geometrical forms is reflected in applied arts; analogies can be seen in Jūlijs Straume's furniture design (around 1936) (Fig. 6a, 6b) and in Vilis Vasarinšs's pottery which are similar to the works of Czech cubists in terms of massing.
The striking example of references to the crystallization forms of architectural Czech Cubism is the book cabinet made by Jūlijs Madernieks (Fig. 7a, 7b), which simultaneously displays the contemporary aesthetics of Art Deco. The examples merely confirm the views held by Sigfried Giedion that cubism was a manifestation of the quest that many artists were on, rather than an invention of any single person, for example, Picasso [5].

\section{Interpretation of Folklore and Art Deco}

Regardless of creative potential, artists and architects in many of the new states conformed with the flow of contemporary trends, including folklore, which became one of the defining sources of inspiration for stylization. The self-determination of the new states, which used to be and still is typical of all cultures and civilisations, manifested itself by means of expression found in folklore.

The boom in decorativeness in architecture in the 1920s and 30s is associated most closely with Art 
Deco aesthetics, in which stylizations of folkloristic ornaments and forms occupied a niche among the many variants. Although according to a number of researchers [1] Art Deco complies with difficulty to attempts at defining it precisely, one of these variants deserves the name Folkloristic Art Deco. These processes share an analogous interpretation of folklore characterizing the era, and, in accordance with stylization of forms, can be included into the niche of folkloristic Art Deco. In some examples, a conscious pronouncedly modernized and exaggerated/exacerbated deviation from the authentic ethnographic model can be seen, thus highlighting a post-modernistic trend.

During the interwar period, phenomena in which inspiration or quotes from folklore can be found to a lesser or greater degree had names related to "adjacent" cultural phenomena: in Latvia, contemporaries used the term Nationally Constructive style, because Russian constructivism was topical; the term National Romanticism, Folk Romanticism or Latvian style has also been retained. The latter designation applies to the time before the First World War; however, as the term and phenomenon Art Deco in art and architecture was defined as late as in the 1960s, a certain patriotic continuity of the concept determines that in Latvia, phenomena including elements of folklore are attributed to national Romanticism. In Poland, it is called the Zakopane style (styl zakopiański), because it drew inspiration from the culture of the mountain-dwellers of Zakopane; in Czechoslovakia, it is known as Rondocubism (rondokubismus), because architectural Czech Cubism had just ceased to exist as a phenomenon prominent and pronounced only in Czech architecture. Discussion regarding the time period in Czech architecture from 1920 to 1923 is relevant; the period is defined as the last phase of architectural Czech Cubism - the third cubism style, and as the Legiobank style (sloh Legiobanky) [8], the national style (národní sloh, národní styl) and national decorativism (národní dekorativismus) $[13,14]$. Historian Zdeněk Lukeš characterizes work from this period as a specific Czech version of Art Deco [24]. Also, when writing about the success of Czech applied arts at the 1925 exhibition in Paris, Milena Lamarova remarks that manifestations of national decorativism, or Czech Art Deco, in applied arts has come to an end [13].

In Polish art history, the term Polish Art Deco "national-folkloristic style" (ludowo-folklorystyczny) can be found in characterizations of the art and architecture included within the scope of Art Deco aesthetics [27]. Scientist Irena Humla proposes the term "the style of regained independence" (,styl odzyskanej niepodległości”) [11], whereas when the creative work of Polish artist Zofia
Stryjeńska from 1891 to 1976 is discussed, it is consistently attributed to folkloristic Art Deco [34].

National folklore as a significant artistic presentation for architecture has been used in Latvia, Czechoslovakia and Poland. For example, the representative portrait of Polish president Prof. Dr. Ignacy Mościcki with kilim with folklore motifs in Art Deco style on the background; the Star sign (Zverokruh) dining room, so-called President's Hall in the Bartoň-Dobenín family palac (1501-1660; Nové Město nad Metují), that was reconstructed by Frantiśek Kysela and Pavel Janák in 1921-1924 (Fig. 8a, 8b).

A similar reconstruction was also carried out in Latvia, the most ornate manifestations of folkloristic Art Deco attributed to Ansis Cīrulis, who implemented the theme of Art Deco mirth and the sun in the interior of the Ambassadors' Accreditation Hall in Riga Castle (the castle of the Latvian president since 1918) in the time period from 1926 to 1929: the saturated green hue used on the walls with an unusual symbolism of the sun, rhythmically arranged murals symbolizing the optimism of the nation, as well as such custom-made interior items as rugs, curtains, ceiling lamps and furniture decorated with intarsia (Fig. 9a, 9b).
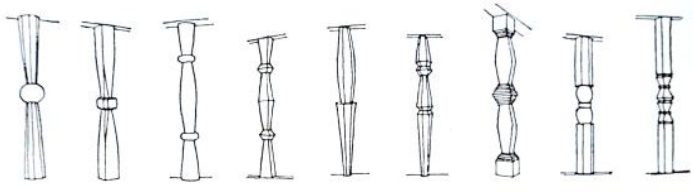

Fig. 13. Examples of posts in Latvian vernacular architecture acording to Pauls Kundziņš's 1952 publication Zwei bezeichnende Schmuckformen in der frühen Holzarchitektur Nordeuropas [41]

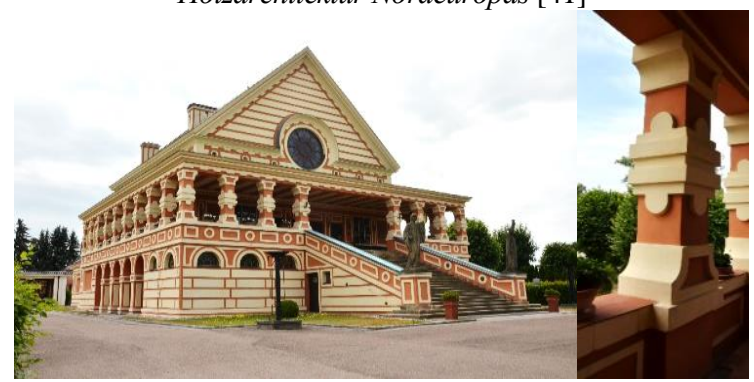

Fig. 14a, 14b. Pavel Janák. The crematorium in Pardubice, Czech Republic, 1922-1923 [46]

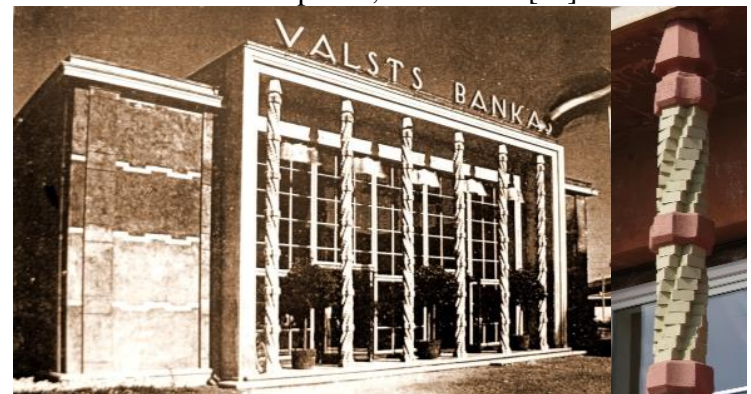

Fig. 15a, 15b. Pauls Kundziņš, The pavilion of the National Bank at the exhibition of Zemgale Region in Jelgava, Latvia, 1937 [50; 46] 


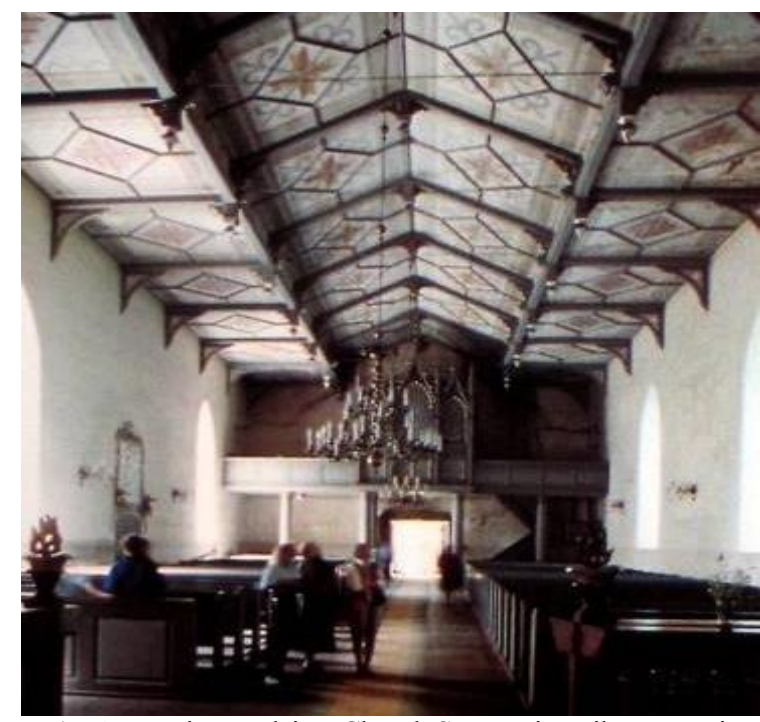

Fig. 16. Pauls Kundziňš. Church St. Jāna in Trikāta, Latvia $(1607 ; 1694)$ interior with ceiling painting in 1930s. [49]

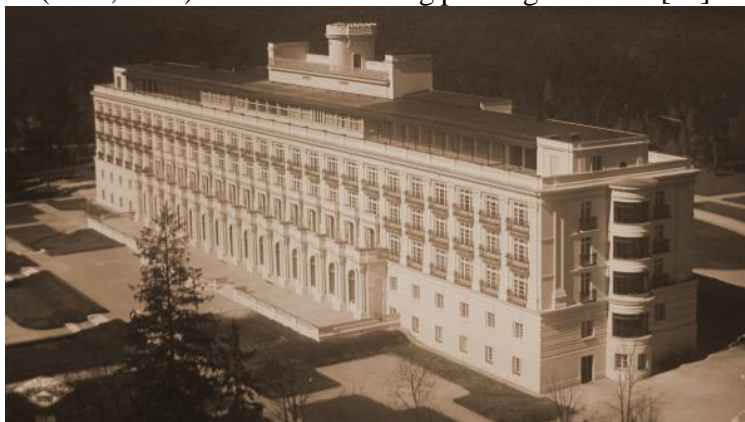

Fig. 18. Eižens Laube, Resort hotel «Ķemeru viesnīca», Jūrmala, Latvia, 1933 [47]

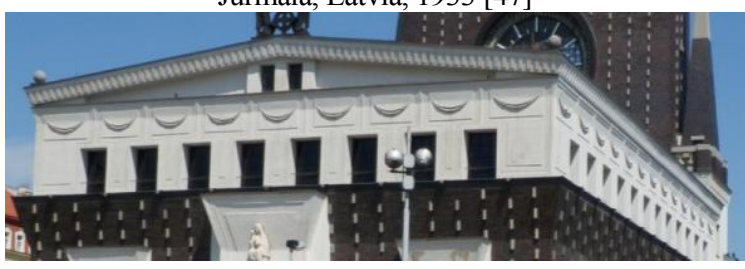

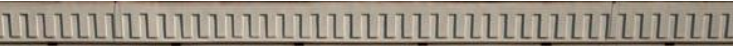

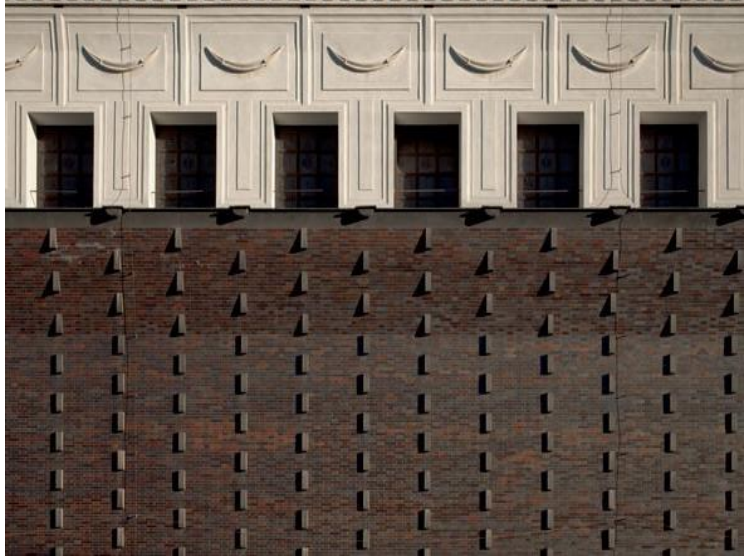

Fig. 20a, 20b. Jože Plečnik, Church of the Most Sacred Heart of Our Lord in Prague, Praha. 1928-1938 [46].

Facade building ornaments inspired in Classicism.

Our Lady, modernism in the tectonics of the façade and classical ornaments - co-existence of various eras

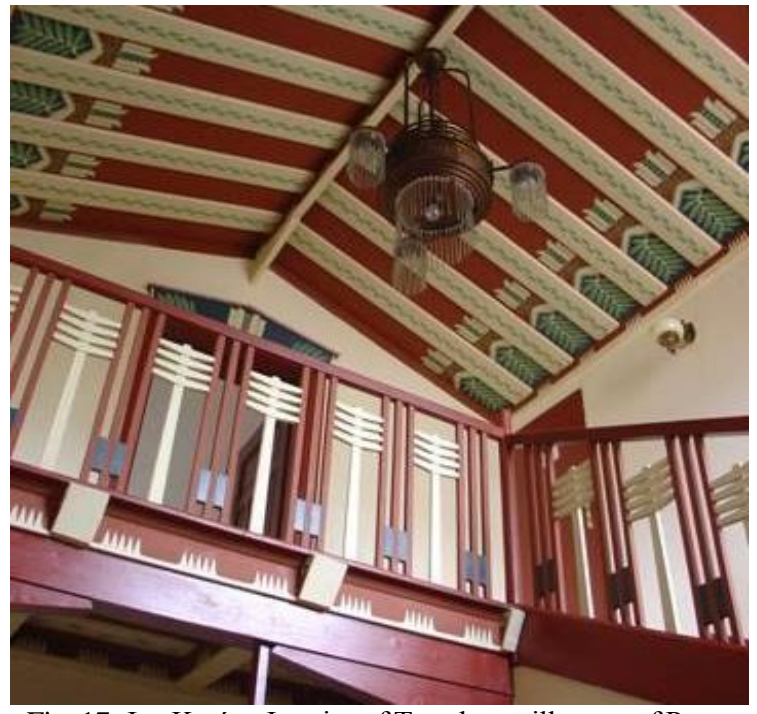

Fig. 17. Jan Kotéra. Interior of Trmalova villa near of Praga (Praha-Strašnice), Czech Republic. 1902-1903 [51]

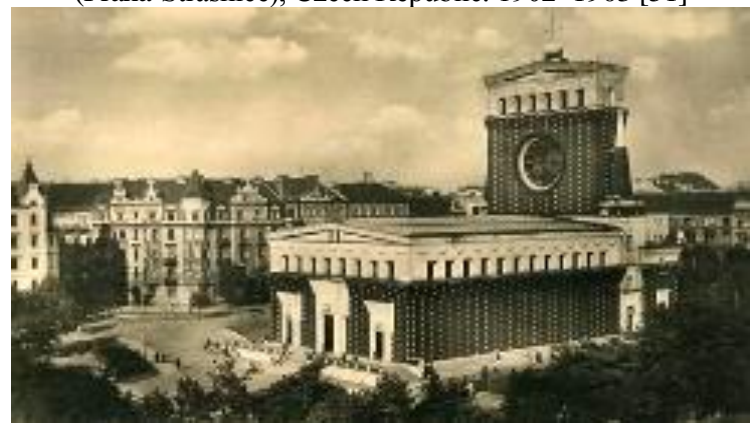

Fig. 19. Jože Plečnik, Church of the Most Sacred Heart of Our Lord in Prague, 1928-1938 [44]

A peculiarity of the Czech people - the idea to announce their national self-determination and protest against the Catholic church by means of crematorium architecture - manifested itself in a pronouncedly folkloristic manner in Pavel Janák's design in Parubice (1921-1923). Rich in murals by František Kysel [25], the crematorium has been made similar to vernacular architecture and at the same time continues the rhythm of forms borrowed from Renaissance that were a favourite with Czech cubists. In Latvia, however, the shape of vernacular posts (examples of posts in Latvian vernacular architecture according to Pauls Kundziņšs's 1952 publication Zwei bezeichnende Schmuckformen in der frühen Holzarchitektur Nordeuropas) (Fig. 10), which in Janák's work are stylised in a 'cubist' manner, was expressively rendered in brickwork by Pauls Kundziņš (1937, the stanchion at the entrance to the National Pavilion of Banks at the exhibition in Jelgava), thus affirming the close ties between the folklore of various European nations (Fig. 12a, 12b).

Both prior to the First World War and during the interwar period, the style of interiors inspired by a feeling of national patriotism included the principles of folkloristic Art Deco. The geometricalized polychrome interior of the villa of Jan Kotera Trmalov (1902-1903) near Prague (Praha-Strašnice), the Zakopane style room at Dr. Dlusk's sanatorium in Zakopane, (1910; 
author of the interior - Wojciech Brzega), the ceiling of Trikāta Church designed by Pauls Kundziňš (Fig. 13), with stylized vernacular ornaments, and the interior designed by Slovenian architect Dušan Jurkovič for a hotel in Pustevny (1897-1899, Radhošt, the Czech Republic) are all like this.

\section{Modernization of Classical Forms}

Both Jānis Čakste and Tomáš Garrigue Masaryk, the respective presidents of Latvia and the Czech Republic, saw architecture as a major tool for representing the new state and manifesting the independence and mightiness of the new state. The 1920s were dominated by folkloristic Art Deco, whereas the 30s saw an arrival of stylized classical forms. The president's castle, which is building number one for every country, was to become a herald of the mightiness of statehood, which can be most directly achieved by using the forms of classical antiquity. Latvian Eižens Laube and Slovenian Jože Plečnik were contemporaries of the same age and were prominent representatives of their profession, and a number of important parallels can be identified in the professional activities of the two architects at this time.

Laube and Plečnik masterfully used the means of expression of the architectural traditions of classical antiquity, and the use thereof in the creative work of Laube and Plečnik shows the two architects' attitude to the universalism of these forms within a context of modernism. Both architects recognized the language of classical architecture as a basis for the development of architecture, at the same time synthesizing it with modern means of expression rather than blindly following it. Both architects worked on the modernization of the stately residence of the president. In the $1930 \mathrm{~s}$, both architects developed solutions that were unusual and nontraditional for their country for large-scale construction projects representing the new statehood: Laube's design for the Kemeri Hotel (1933), and Plečnik's design for the Church of the Most Sacred Heart of Our Lord in Prague (1928-1938, Kostel Nejsvětějšího Srdce Páně) (Fig. 18a, 18b, 21). Both masters of architecture can be considered early postmodernists [16].

In 1920, Slovenian architect Jože Plečnik, who was one of the most talented students of Otto Wagner, officially appointed by president Tomáš Garrigue Masaryk, became architect for Prague Castle in Hradčany, the residence of the president of Czechoslovakia. Due to his major contribution to Czech architecture, he is often also called a Czech architect [9], because his creative
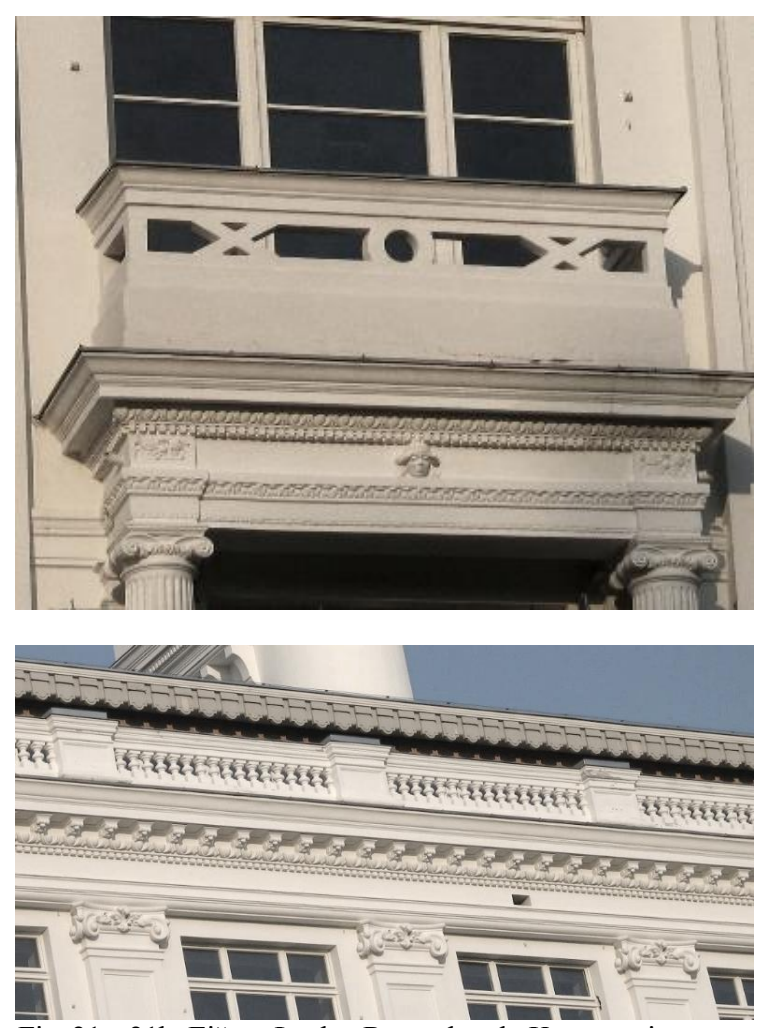

Fig. 21a, 21b. Eižens Laube, Resort hotel «Kemeru viesnīca», Jūrmala, Latvia, 1933 [46]. Facade building ornaments rooted in Classicism. The head of a young girl in folk costume with crown, modernism in the balcony railing and classical ornaments - co-existence of various eras

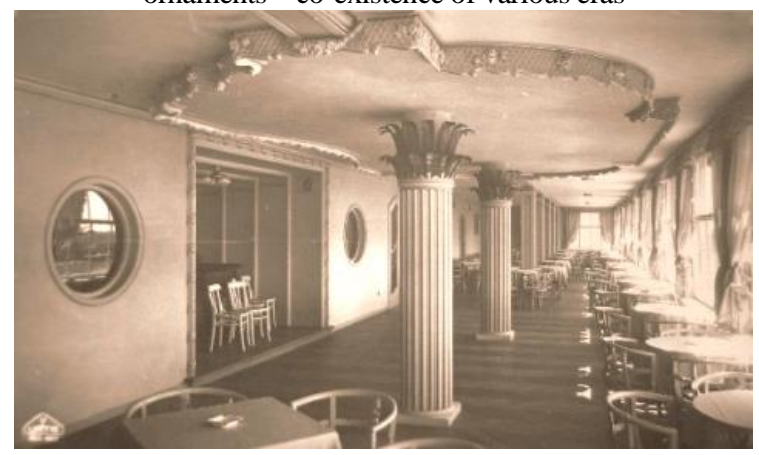

Fig. 22. Roof café, Resort hotel «Kemeru viesnīca», Jūrmala, Latvia, 1933 [48]

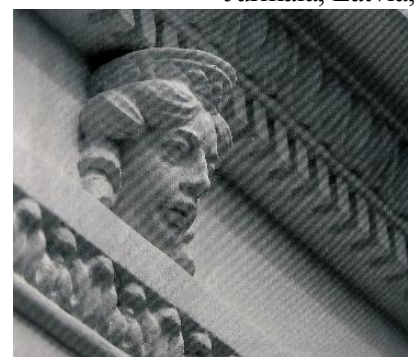

Fig. 23. Young girl with wreath or crown in fasade. Eižens

Laube, Resort hotel

«Ķemeru viesnīca», Jūrmala, Latvia, 1933 [45]

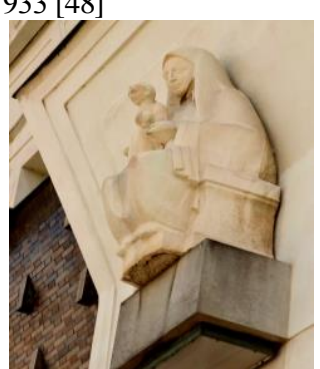

Fig. 24. Our Lady with Christchild - central front entrance sculpture Jože Plečnik, Church of the Most Sacred Heart of Our Lord in Prague, 1928-1938 [46] 
work belonged to three cultures, namely, Slovenian, Czech, and Austrian, which for a long time were united in a single state. Plečnik was fascinated by Venetian architecture, especially Palladianism, until in the $30 \mathrm{~s}$ he gave in to the fashions of Neoclassicism. Moreover, he was fascinated by a legend that Slovenians were the descendants of Etruscans, which contributed to him involving the architecture of classical antiquity even more [29]. However, with his unique rather 'Egyptian-esque' laconism, which was heralded in a most ornate way in the centre of Prague, in Vinohradi, Plečnik's 20th century Classicism differed significantly from universally accepted concepts. From 1928 to 1938, a rather bold idea synthesizing inspiration drawn from Art Nouveau and Classicism was implemented, resulting in a wonderful design: The Church of the Most Sacred Heart of Our Lord in Prague (Kostel Nejsvětějšího Srdce Páně) rises mightily skyward like an ancient Mesopotamian temple. Historian Cezary Wąs interprets it as a large tombstone, a monumental memento mori, whose belfry with its oversized clock draws attention to the transitory nature of earthly life [28, 64].

The massing of the Church of the Most Sacred Heart of Our Lord is avant-garde and the colour contrasts between the various hues - a bright white hue on the upper floors and entrance portals as opposed to the pronouncedly dark semi-basement floor, as well as contrasts between planes, with their rich texture resembling ermine - create a symbolic allusion to Biblical texts to do with the spiritual ruler (king) (this is an almost postmodern interplay of ornamental clinker brickwork) on the semi-basement floor contrasting with the comparatively serene wall planes on the upper floors. This might be one of the interpretations of Plečnik's famous work. According to the writings of English architecture historian Richard Weston, the Church of the Most Sacred Heart of Our Lord, like many of Plečnik's projects, was designed drawing inspiration both from semantic and tectonic motifs [31] (Fig. 18a, 18b).

Eižens Laube is one of the most prominent Latvian architects, and his creative work started in the Art Nouveau era - at a time when the eclectic style was coming to an end and new architectural principles were taking shape. His contribution to the visual image of Riga is significant, with over 100 residential and public buildings constructed. The 'brightest testimony' [15] of Laube's professional career - the Kemeri Hotel (1933), which has been recognised as neo-eclecticism structure and listed among the three most prominent monuments of the monumentalism era of the 1930s in Latvia, brings to mind England in the 1930s, when SS Normandie, on its maiden voyage in 1935, was “like a floating advert for L'Art Décoratif" [26].
Art Deco, which had been called 'the liner style' since the first trans-Atlantic voyages of British shipping company Royal Mail Steamer in 1907 when the large ocean liners RMS Mauretania and RMS Lusitania began a new leisure era in shipping, conquered the seas. It shaped the legendary image of elite life and transformed ships into floating palaces and flats into ship cabins. It cannot be denied that the design of the modern ships influenced the architectural forms of the time [10].

Although the new Latvian state did not have a Normandie of its own, the lavish design of Laube's Kemeri Hotel, nicknamed 'the White Palace', embodied the legend of sophisticated aristocratic life that stemmed from les Années folles and that was transferred to large ships in the 1930s. In the architectural forms of the hotel, Eižens Laube masterfully embodied the metaphor of the mighty ocean liner, at the same time implementing the representative function for the Latvian state in the structure. The aesthetic principle of the metaphor, which was popular in structures built in the Art Deco style of the 1930's (the wheel motif in the Chrysler building in New York is a typical example; 1928-1930, architect William van Alen), blends organically into the scenery of Kemeri Park, the evergreen splendour of which highlights the monumentality of the 'white ocean liner'. The hotel could create a festive ambiance, and prior to the first World War, it was popular with both Latvian citizens and prominent people from all over Europe, such as former monarchs including the Albanian royal couple, as well as London bankers, which the press did not hesitate to show in photo coverages $[2 ; 18]$.

At a time when fascination with the fluid lines of Streamline Moderne ran wild in building designs as a reaction against the language of the rectangular forms of functionalism [20], Laube chose to implement a unique take on the 'ship' trend of the 1930 s in Kemeri woods, using the language of neoeclecticism. The design of the hotel comprises elements of classicism, Baroque, functionalism, as well as Latvian folklore, the latter co-exist harmoniously in the solutions used for the exterior and the interiors: here, the image of a young woman in Latvian folk costume co-exists with structural ornaments rooted in Classicism on the façade (Fig. 19); an oriental or French motif enriched with Art Deco aesthetics appears in the interiors; with a change in point of view, the building looks as compelling as a mighty Baroque palace if looked at from the side of the park, whereas on the main façade, a captain`s bridge beckons as if from a medieval ship. The eclectic accents have been masterfully amalgamated into a single harmonious whole, but in general they speak the language of Art Deco principles. 
Metaphor has been used in the visual image of the monumental massing: an interpretation of the liner and polychrome motifs of classical antiquity, a similar rhythm in the arrangement of the façade details, and idealization of a sculptural image of a woman. This, as well as the premises of the hotel that, according to Agatha Christie, were "cleverly decorated by a modern form to resemble a ship's cabin de luxe" [3], can be seen in the preserved photographs of the roof café, with porthole windows on one side and a glass wall on the other, creating the illusion of a ship deck. The solution used for the capitel of the columns in the café hall shows signs that respect was paid to the allure of pharao-ruled Egypt, which had fascinated Europeans since the Napoleonic era and saw an extremely expressive stylization in hotels and restaurants within the framework of Art Deco. (Fig. 20) Chair back spindles with a dynamically winding cut accentuate the forms of 1930s Art Deco.

The creative manifestation of both these works was defined by two key aspects: modernization of classical forms, and a desire to represent the self-determination of one's nation by means of architecture and to demonstrate the national architecture. Both female images by architects E.Laube and J.Plečnik represent Latvian and
Chech women from the common folk (Fig. 21). Jože Plečnik`s and Eižens Laube`s masterpieces in Prague and Jūrmala, respectively, share monumentality and mightiness at the same time maintaining an analogous considerativeness for the national heritage of one`s country.

\section{Conclusions}

Drawing parallels and searching for analogies and similarities, it can be concluded that the vernacular ornaments and the stylization of the motifs in Latvian and Czech folkloristic Art Deco are contextually and stylistically similar and that there is a willingness to bring poetic folklore characters to life in architecture. In representative architecture, when searching for means of national self-expression, the vernacular, the modern and the classical are synthesized, which in the 1920s can be associated with folkloristic Art Deco, whereas in the 30s, modernized classicism can be identified. As the art history of any nation includes the communicative aspect, it would be impossible to interpret its materials in isolation from other schools, even if they form transcultural rather than direct connections.

\section{References}

1. Bédoyére C. de la, Art Déco. London: Flame Tree Publishing, 2005, p. 384.

2. Bērni jūras svētkos. Atpūta, 1939, Vol. 768, p. 13.

3. Christie, A., Three act tragedy. London: Harper Collins, 2006, p. 15.

4. Giedion S. Space, Time and Architecture: The Growth of a New Tradition. Cambridge, Mass: Harvard University Press, 2002, p. VI.

5. ibidem, p. 31 .

6. Hanson, J. Stockholm - meeting point and source of inspiration. Architecture 1900: Stockholm, Helsinki, Tallinn, Riga, St. Petersburg. J. Howard (ed.), Kirjastus Eesti Tallinn: Arhitektuurimuuseum, 2003, p. 127.

7. Herscher, A. Monument stylu a historická monumentalita. Architekt, 1998, No. 19, p. 48.

8. Hnídková, V. Rondokubismus versus národní styl. Umění / Art, 2009, Vol. 57, Issue 1, p. 74-84.

9. Horešovská, M. Plečnik v Praze tvořil málo, nechtěl brát práci českým kolegům, 2007. [online 3.03.2017] http://www.archiweb.cz/news.php?action=show\&type=1\&id=2668

10. Howard, J., Szczerski, A. Ships in the Night along the Coasts of Bohemia? Modern Design Aesthetics and the Turn of the Liner. In: Modern Art and Central Europe 1918-1968. Vojtěch Lahoda (ed.). Praha: Ústav Dějin Umění AV ČR, 2006, pp. 111-123.

11. Huml, I. Polska sztuka stosowana. Warszawa: Wydawnictwa Artystyczne i Filmowe, 1978, pp. 9-64.

12. Krišane, I. Neīstenotais Aleksandrs Klinklāvs. Mākslas vēsture un teorija, 2006, Vol. 1, pp. 5-14.

13. Lamarová, M. Od rondokubismu k Art Deco. Nový IN, 1998, Vol. 4, pp. 16-19.

14. Legiobanka. Fričová, Y. (ed.). Praha: Titanik, 2015, p. 72.

15. Lejnieks, J. 20. gadsimta pasaule Latvijā. Vai to vainot? Latvijas Arhitektūra, 1999, Vol. 26 (2): pp. 12-20.

16. Lejnieks, J. Laube un Plečniks. Konǵenialitāte. Latvijas Architektūra, 2003, Vol. 6 (50), p. 62.

17. Lejnieks, J. Rīga, kuras nav = Never-built Riga = Ein Riga, das es nie gegeben hat. Rīga: Zinātne, 1998, p. 397.

18. Lejnieks, J., Kemeru viesnīca. Māksla, 1996, No. 3, pp. 37-42.

19. Olszewski A.K., Art Deco. Towards the Definition and Chronology of the Style. Polish Art Studies, Vol. XIV, 1992, p. 73.

20. Olszewski, A.K., Amerykański streamline a europejski modernizm. In: Modernizm w Europie, modernizm w Gdyni. Architektura lat międzywojennych i jej ochrona. M. J. Sołtysik, R. Hirsch (eds.), Gdynia: Urząd Miasta Gdyni, 2009, pp. 31-36.

21. Petrová, S. K art deco přes postmodernu. A naopak? Umění a řemesla, 1989, Vol. 2, pp. 8-10.

22. S. J. [Silinı̌s J.] Arhitektūras izstāde. Izglītīibas Ministrijas Mēnešraksts, 1935, Vol. 1, pp. 82-83.

23. Spārītis, O. Nīderlande, Polija un Livonija - kultūrās izstarojuma un uztveres problēmas aspekti. Latvijas Zinātņu Akadēmijas Vēstis, 2004, Vol. 58(4), pp. 40.-62.

24. Stavební uméní. Kubistická architektura v Praze a jejím okolí. Kolber, G. (ed.), Christoph Hölz, Ch. München: Bayerische Vereinsbank 1994, p. 72. 
25. Švácha R. Lomené, hranaté a obloukové tvary: česká kubistická architektura 1911-1923. Praha: Gallery, 2000, pp. 184-186, 215.

26. Tołloczko Z., T. W kręgu architektury Art Déco. Wydawnictwo Oddziału PAN, Kraków, 1997, p. 43.

27. Tolloczko, Z. Jeszcze o „stylu zakopiańskim” i jego wpływie na architekturę modernistyczną. Przyczynek do kwestii zaniku ludowej inspiracji w architekturze końca XX wieku. Czasopismo Techniczne, Politechnika Krakowska, Z. 1A, 2000, p. 16-25.

28. Wąs, C. Antynomie współczesnej architektury sakralnej. Muzeum Architektury we Wrocławiu, Wrocław, 2008, p. 322.

29. Wąs, C. Architektura Jože Plečnika. Muzeum Architektury we Wrocławiu, Wrocław, 2004, 63 p.

30. Weber, E. American Art Deco. North Dighton: World Publications Group, 2004, p. 112.

31. Weston, R. Materials, Form and Architecture. Laurence King, London, 2003, p. 183.

32. Wettbewerb für ein Drittes (Lettisches) Stadttheater in Riga. Architektenverein, Jahrbuch für bildende Kunst in den Ostseeprovinzen, Herausgeber: Der Architektenverein zu Riga., 1911, V. Jahrgang, pp. 88-89. [online 5.03.2017.] http://archiv.riga-digitalis.eu/jahrbuecher/Jahrb_bild_Kunst_Ostseeprovinzen/Hd_39_1911/\#89/z

33. Zavadil J., Grosz J. Rekonstrukce městské knichovni v Praze. Architekt, 1998, No. 19, pp. $42-47$.

34. Luba I. Dialog nowoczesności z tradycją. Malarstwo polskie dwudziestolecia międzywojennego. Warszawa: Neriton, Instytut Historii Sztuki Uniwersytetu Warszawskiego, 2004, pp. 120-128.

Photographic sources:

35. Český kubismus: architektura a design 1910-1925. A. von Vegesack (ed.). Weil am Rhein: Vitra Design Museum, 1991, p. 212

36. From the collection of the Museum of Decorative Arts and Design in Rīga, photo by Renāte Čaupale, 2016.

37. From the exposition of the National Technical Museum in Prague, photo by Renāte Caupale, 2006.

38. From the exposition of the Renaissance and Baroque Bartoň-Dobenín family palace (1501-1660), Nové Město nad Metují, Chech Republik, photo by Renāte Čaupale, 2016.

39. Hanzlíková, L. Ústřední knihovna MKP oslavila osmdesátku, 2008 [online 1.03.2017] https://ikaros.cz/ustredniknihovna-mkp-oslavila-osmdesatku

40. Kl̦aviṇa, L. Jülijs Straume. Lietišķās mākslas meistars. Rīga: Zinātne, 2004, p. 159.

41. Kundziņš, P. Tautas celtniecības rotājumu motīvi jaunceltnēs. Latvijas Architektūra, 1938, No. 1, p. 19.

42. Latvian Museum of Architecture, F. K1 (Aleksandrs Klinklāvs).

43. Ne acu nenovērst: atjaunots Anša Cìrula meistardarbs Sūtņu zālē. [online 7.09.2016] http://www.la.lv/ne-acunenoverst-atjaunots-ansa-cirula-meistardarbs-sutnu-zale/

44. Nový, O. Česká architektonická avantgarda. Praha: Prostor, 2015, p. 159.

45. Photo by Ilmārs Znotiṇš, SestDiena. No. 175, 2004, 30.jūl./6.aug., p. 10.

46. Photo by Renāte Čaupale, 2006, 2009, 2016

47. Resort hotel "Ķemeru viesnīca", Jūrmala, Latvia, postcard, publisher "Fotobrom”, ca.1930, RVKM (Museum of the History of Riga and Navigation), Inv. No. 135593.

48. Roof café, Resort hotel "Kemeru viesnīca", Jūrmala, Latvia, photo by V. Upītis, 1930s, RVKM (Museum of the History of Riga and Navigation), Inv. No. 150147.

49. Spārītis, O. Latvijas luterānnu dievnamu šodiena. Rīga: Nordik, 1999, p. 73.

50. Tīlmanis, O. Dr. arch. P. Kundziņa darbs mūsu tautas celtniecības pieminekḷu kopšanā. Latvijas Architektūra, 1938, No. 6, p. 214.

51. Trmalova vila [online 6.04.2017] http://www.prague.eu/en/object/places/389/trmal-villa-trmalova-vila

INFORMATION ABOUT THE AUTHOR:

Renāte Čaupale - Ph.D. in Architectural History (2010, RTU). Docent at the study programme Architecture of Riga Technical University (RTU), researcher in Latvia University of Agriculture (LLU), Department of Landscape Architecture and Planning. Academic and research interests: history of 20th \& 21st century architecture, Art Deco. E-mail: Renate.Chaupale@gmail.com

Kopsavilkums. Mākslas un arhitektūras saskarsmju kopsakarības starp Latvijas un Čehijas tautām ir salīdzinoši fragmentāras. Tomēr pastāvot vienā lielā Eiropas kultūrtelpā, atrodamas gan paralēles, gan analogiijas, jo to nosaka mākslas un arhitektūras komunikatīvā loma.

Divdesmitā gadsimta divdesmitajos - trīsdesmitajos gados jaunās valsts Latvijas arhitektūrā bija saskatāmas noteiktas, tam laikam Eiropai raksturīgas, aktivitātes. Art Deco estētika bija viens no nozīmīgākajām arhitektoniskajām un mākslinieciskajām izteiksmēm starpkaru periodā. Tās izteiksme mainījusies līdzi laikam, tomēr saglabājot Art Deco dekorativitātes principus. Art Deco estētika ietver vairākus atšķirīgus, bet savstarpēji saistītas tendences, tostarp:

Folkloras interpretāciju - Ansis Cīrulis Latvijā un Pavel Janák Čehoslovākijā meistarīgi veidoja interjerus atbilstoši modernām stilizācijas tendencēm. Neatkarīgi no viṇu radošā potenciāla, mākslinieki un arhitekti daudzās jaunajās valstīs iẹ̦āvās laikmeta tendenču plūsmā, arī folkloras, kas kḷuva par vienu no noteicošajiem iedvesmas avotiem, stilizācijā. Tā ar folkloras izteiksmi manifestējot jauno valstu pašnoteikšanos, kas bija tipiski visām kultūrām un civilizācijām. Šos procesus vieno analoǵiska folkloras interpretācija, kas pieḷauj ietvert tos folkloristikā Art Deco nišā. Atsevišķos piemēros, kad folkloristiskais Art Deco reprezentējas kā 1920.-1930. gadu modernisma mākslas un arhitektūras organiska sastāvdaḷa, 
saskatāma apzināta, izteikti modernizēta atkāpe no autentiskā etnogrāfiskā parauga, tā iezīmējot prepostmodernisku ievirzi.

Klasisko formu modernizāciju, kas bija aktuāla tieši vadonības kulta periodā pirms Otrā pasaules kara. Vēlme ar arhitektūru reprezentēt savas tautas pašnoteikšanos un izteiktie laikmeta nosacījumi noteica Jože Plečnika un Eižena Laubes meistardarbu Prāgā un Jūrmalā monumentalitāti, vienlaicīgi saglabājot analogu iejūtību pret nacionālo mantojumu, ar to būdami tik atšķirīgi.

Latvijā un Čehoslovākijā ir likumsakarīgi atrodams Eiropas zemēm identisks kultūras substrāts, nevis nejaušu gadījuma rakstura ieskaloti stilu mākslas elementi. Jebkuras tautas mākslas vēsture ietver sakaru aspektu, jo nav iespējams tās materiālu interpretēt izolēti no citām skolām, pat, ja tās neveido tiešus sakarus, bet transkulturālus, un darbā ar piemēriem tiek atklāts Latvijas un Čehijas nacionālās arhitektūras idejiskās kopsakarības. 


\title{
Trends in Development of Public Outdoor Space, an Example of Copenhagen
}

\author{
Una Īle, Latvija Universoty of Agriculture
}

\begin{abstract}
The research is based on the previous studies of the author on landscape quality and modern development trends based on the knowledge of theories that have emerged in recent years in the Scandinavian countries. Diverse compositional solutions for public outdoor space were observed in both Norway and Sweden that determine and highlight modern and urban open space easily accessible for each user. The article describes current trends, highlights ways how to plan and implement public outdoor space revealing the experience of the city of Copenhagen and Superkilen Park which was officially opened in 2012.

Keywords: public outdoor space, development trends, improvement
\end{abstract}

\section{Introduction}

Jan Gehl, a Danish architect and city designer, claims that three basic directions may be distinguished in functional and aesthetic design of public outdoor space: the necessary activities, intended activities and social activities. Recreation function in this division corresponds to the second category where its activities directly depend on suitable outdoor conditions - "if there is a wish.... and if the time and place allows" [1]. What is the experience of other cities? It is worthwhile to study the experience of Nordic countries which are located in the same climate zone as Latvia and in similar coastal conditions [2]. The Nordic countries long ago worked out the policy supporting a successful dialogue between the community and city planning process. Not only the big cities (Helsinki, Oslo, Stockholm), but also the small ones (Tampere, Tapiola, Malme) could be mentioned as urban areas where city planners stress the significance of the involvement of society in the planning process [3].

The main task of the municipal plan of Copenhagen in 1993 was to create a comprehensive development in the integrated city where different urban activities are combined in unity if it possible from the point of view of city development planning, environment and transport infrastructure planning principles. In the time period from 1975-1990 the number of Copenhagen population decreased by 58,000 people while the number of residents in other parts of the country rose. Copenhagen city planners considered that one of the reasons could be unpleasant living conditions in the capital city. Consequently, in 1993 the main task of the municipal plan of Copenhagen was to provide high quality opportunities for apartment buildings by setting the priority for designing of attractive areas near the water bodies accessible to public services and public transport [4]. Currently, European policy of urban environment mostly follows tendencies of urban development instead of setting the guidelines for city development. There is a big gap between the cities of Western Europe and those of post-socialism countries which have to overcome transition processes in various areas of life [5]. Kevin Lynch states that it is possible to design buildings in the way that people may fully get accustomed to external environment, navigate and learn roads and routes. He write that a successful environment landscape offers its user an important feeling of emotional safety [6]. Building intensity should not be implemented by decreasing or restricting functional diversity of the public open space. Each users' group of any open space has its specific needs which should be respected by creating both passive or active recreation zones and entertainment places for people of different ages, which is illustrated in Figures 1, 2, 3. A special attention should be paid to the landscape quality in the public open space improvement plans, which is a factor increasing a recreation level when purposefully implemented [1]. Therefore the aim of the research was to acquire new knowledge on trends of public outdoor space development on the example of Superkilen Park in Copenhagen and shed a new light on planning approaches in the field of landscape architecture.

\section{Materials and Methods}

The methodological and informative basis refers to current analytical review of open spaces in the central part of Copenhagen which were visited and analysed in April, 2017. Within the framework of the research the public outdoor space in the centre of Copenhagen was investigated and analysed on the basis of current trends in the design and planning approaches, because implemented design solutions of public outdoor spaces of Copenhagen may be of interest to landscape architecture professionals at the national level of Latvia. The literature review included the study of publications and electronic resources depicting information of improvement of urban spaces in the 21st century. The induction method was used in the research which was based on the analysis of visited areas and obtained photo 


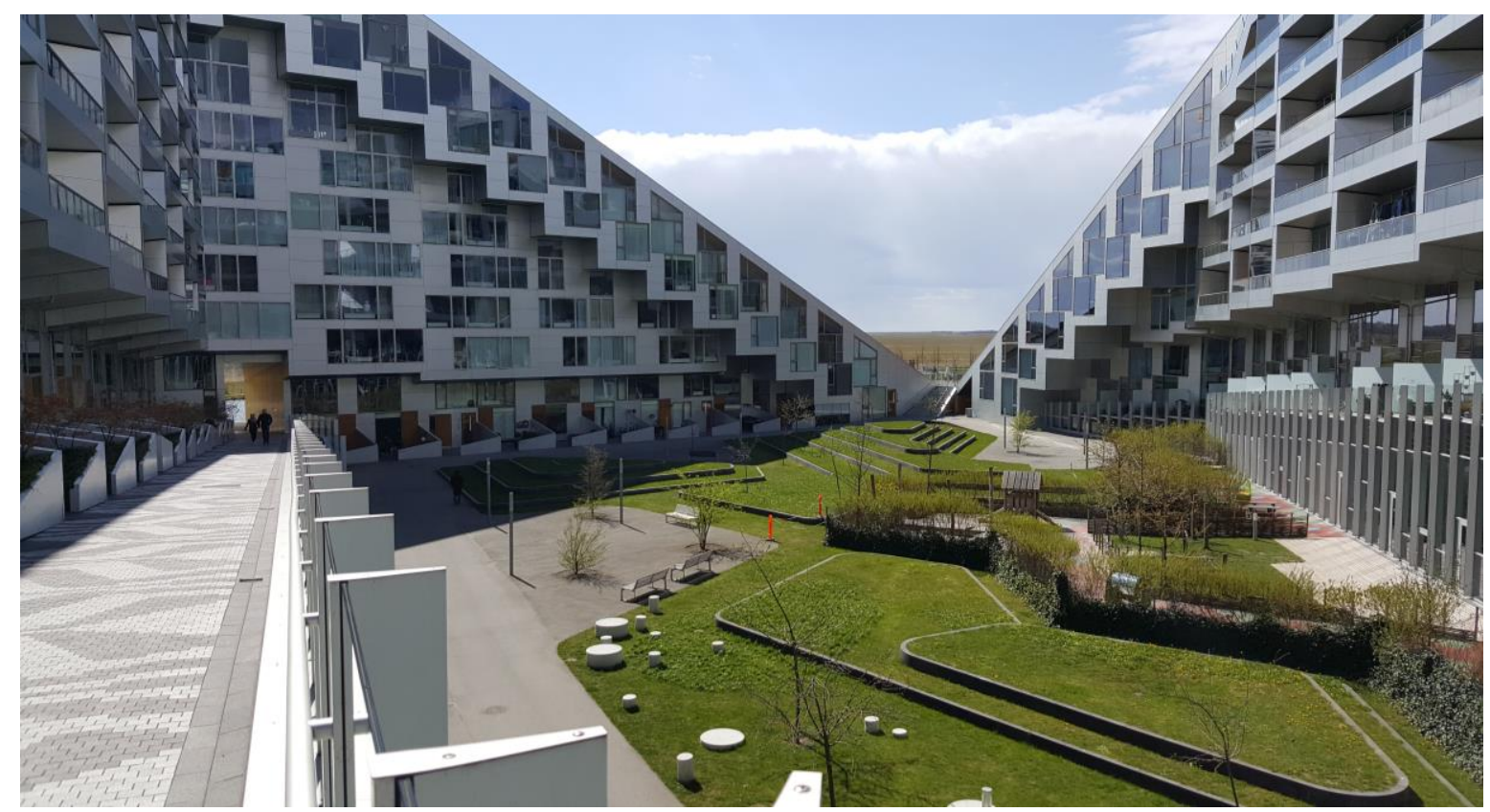

Fig. 1. Asger Jorns Allé: a magnificent shape and solution of 8House residential buildings [Source: photo by the author, 2017]

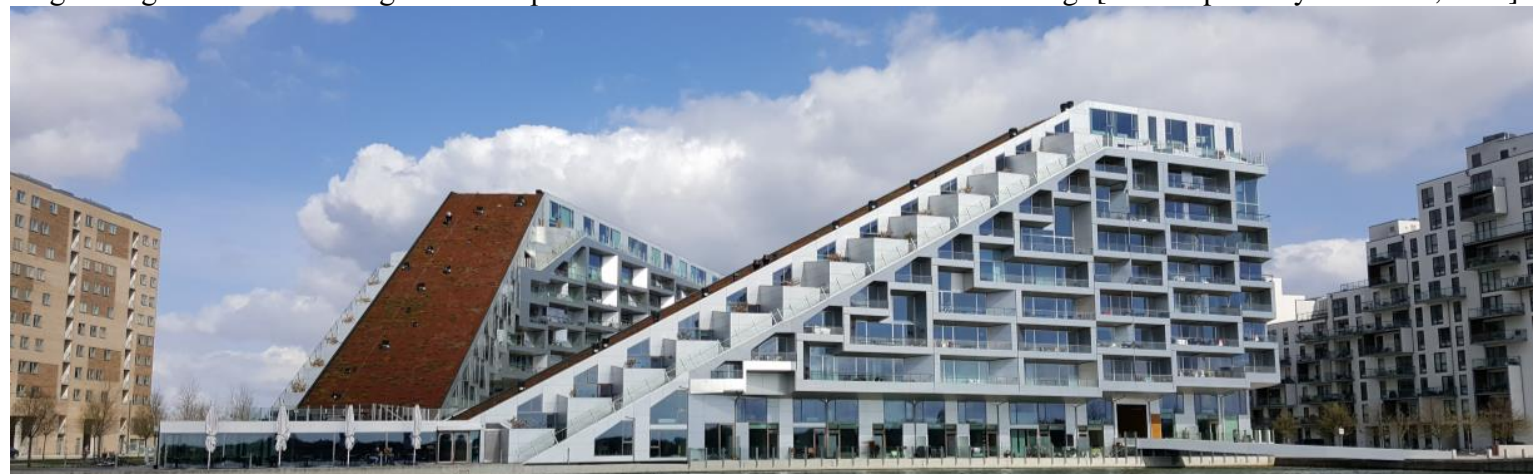

Fig. 2. Inner courtyard of 8House residential houses [Source: photo by the author, 2017]

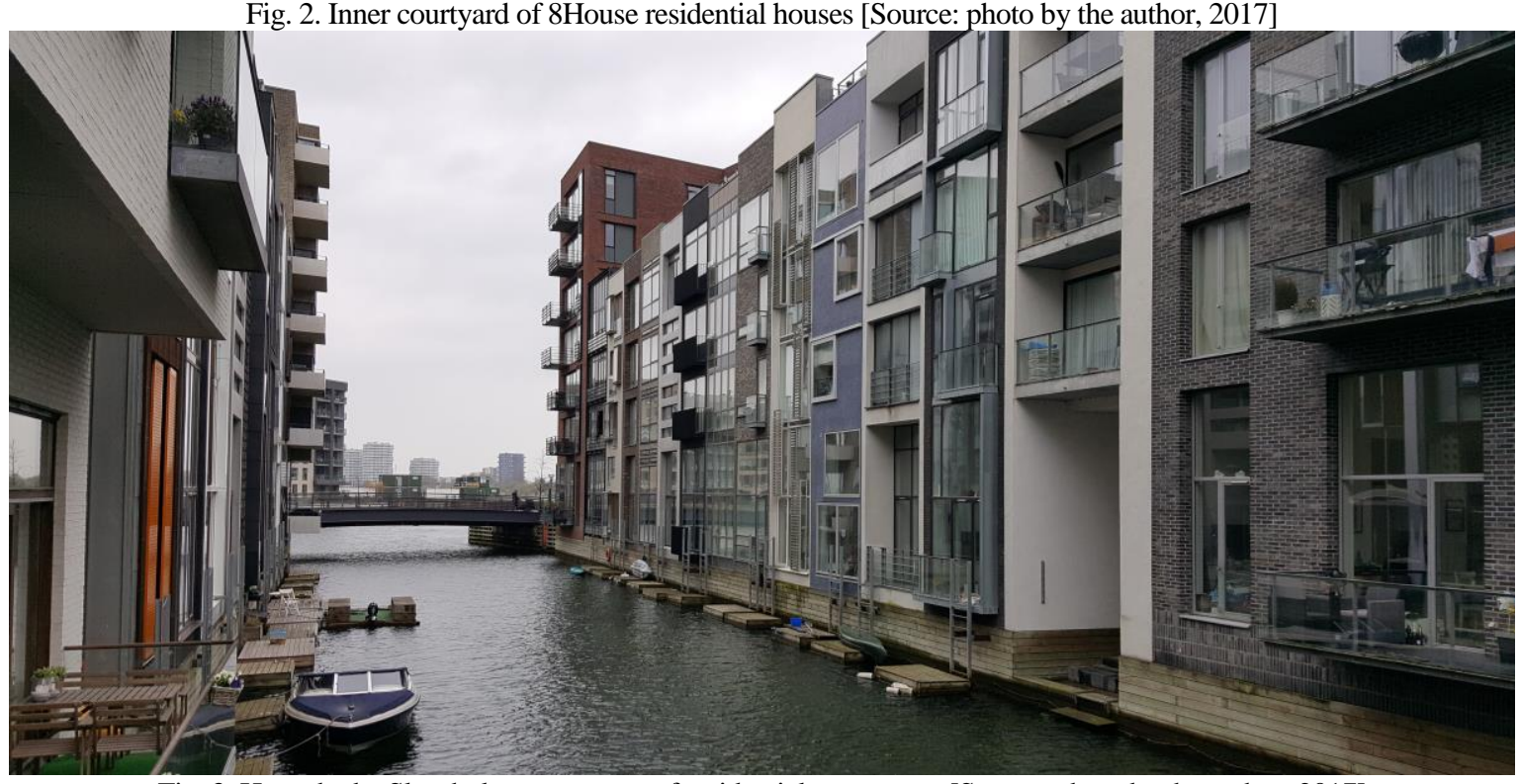

Fig. 3. Havenbadet Sluseholm - new area of residential apartments [Source: photo by the author, 2017] 
fixations in Copenhagen. The monographic or descriptive method was used in the research for the analysis of the results based on the theoretical assumptions and the previous studies of the author on public outdoor planning solutions and composition elements - shapes, proportions, colour, contrasts, nuances, rhythm etc. which have been published in the scientific articles: Île U., (2012), Compositional planning of residential outdoor space in courtyards. Scientific Journal of Riga Technical University, Architecture and Urban Planning. Riga, RTU, pp. 6-11; Île U., (2011), Landscape composition development stages in multi-storey residential areas of the Baltic sea region. Science Future of Lithuania. Vilnius, Vilnius Technika, pp.16-22; Île U., (2011), The aesthetic quality of landscape composition in the multi-storey residential areas. Scientific Journal of Riga Technical University, Architecture and Urban Planning. Riga, RTU, pp. 108-114.

\section{Results and Discussion}

Jan Gehl, a Danish architect and city planner, has contributed significantly to functional and aesthetic design and improvements of the public outdoor space regarding navigation of vehicles and pedestrians in cities [7]. Kevin Lynch, an American city planner, is known for his empirical investigations on city planning. He analysed how individuals perceived and moved in a city, how urban environment influenced children and how to use human perception of physical shape of cities and regions as the conceptual basis for good city design. Lynch claimed that elements in cities may be divided into five groups: paths, edges, districts, nodes and landmarks [8]. Consequently, theoretically the public outdoor space in Copenhagen with its diverse compositional solutions, ability to navigate in specific areas proved to be safe and comfortable urban environment for its users. The public outdoor areas in the central part of Copenhagen were visited and urban improvement projects were recorded by the author; Superkilen Park was selected for the closer investigation. The park is divided into three parts: The Red Square, The Black Market, The Green Park; these visually different designs create environmental contrasts, see Figure 4. The space perception and composition are two different concept groups, which up to now do not have corresponding mutually connected problems, research and perceptions.

On the one hand, an impression of human psychophysiology is created, but, on the other hand, a variety of objects with compositional elements - a shape, proportions, colour, rhythm, nuances etc. prevail $[8 ; 9 ; 10]$. These compositional elements of the analysed Superkilen Park highlight current trends and represent a distinctively different visual overview in the urban environment.

Superkilen Park is an informationally saturated park territory in the urban environment, reflecting cultural diversity encountered in Copenhagen city. It is a collection of famous objects or their copies from 60 countries. The main aim of the park is to reflect the ethnic diversity of Copenhagen, the elements used in the park symbolizes different nationalities from all over the world. Objects in the park have been specially imported from a certain country or copied from original designs. A walk through the park resembles a global walk ranging from neon signs from the USA, traditional swing from Iraq, bench design from Brazil, Spanish statue of a bull, fountain from Morocco, boxing rink from Thailand, rubbish bins of English design and soil from Palestine. Each object is accompanied by a small plate describing the object, what it is and where it is from [11].

Superkilen Park is the result of collaboration of local residents because the design reflects different nationalities living in Copenhagen. The idea was to create a publicly accessible area when everyone feels at home, and it is not important where has a user of a specific place come from. The total length of the park is $750 \mathrm{~m}$, it is located in Nørrebro district to the north of Copenhagen centre which ethnically is one of the diverse regions in the city.

It was a challenge for the authors of the park to make the public outdoor space attractive to any user and to be applicable in diverse contexts, see Figures 5, 6, 7. The authors of the Superkilen Park consider that they have achieved a balance. They are artists from Superflex, architects from Bjarke Ingels Group (BIG) and landscape architects from Topotek1. The idea of creation of this park belong to the city of Copenhagen which was supported by Realdania which is a private Danish organisation supporting philanthropic projects of architecture and city planning [11].

Officially Superkilen Park was opened in June of 2012, its total are is $30,000 \mathrm{~m} 2$; it is possible to use bicycle paths to get to other districts of the city; there are various playgrounds and sport grounds, recreation places to spend time in different culture activities, picnic places with grill elements, see Figures 8 and 9. The parts of Superkilen Park: the Read Square's main functions are to create an impression of recreation and modern life style. Its stimulating colours - bright red, orange, pink - enhance the desire to work actively and generate the flow of energy, but an expressive colourful and attractive character is played through colour contrasts, see Figures 10 and 11. 


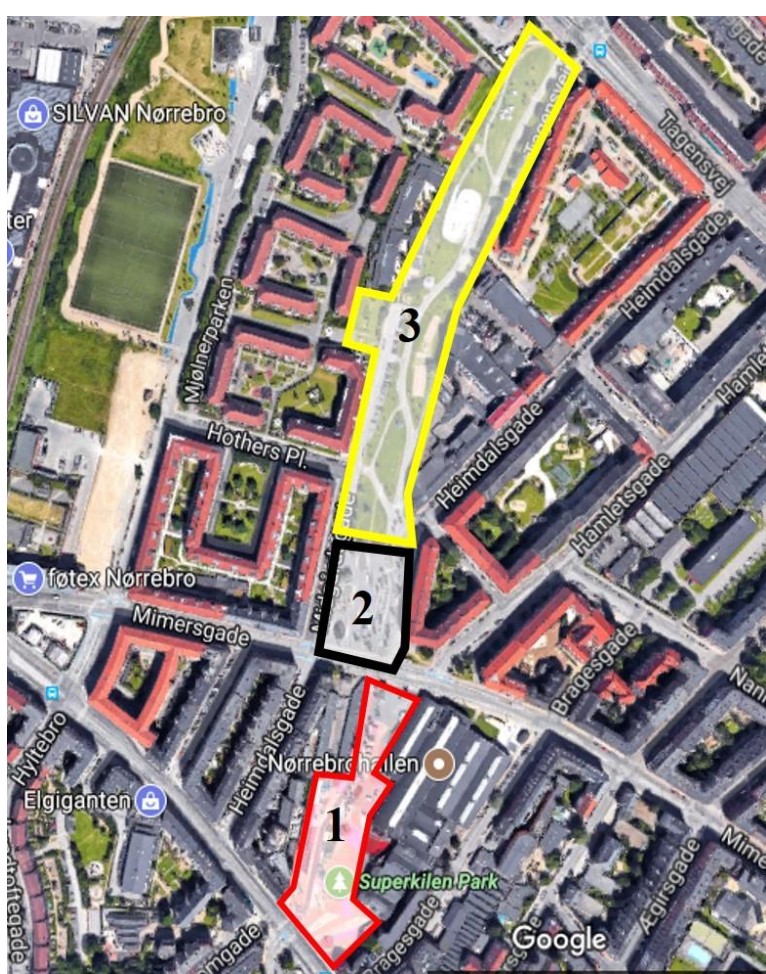

Fig. 4. The territory of Superkilen park: Red Square, Black Market and Green park [Source: Scheme created by the author, using aerophoto map from www.google.lv/maps, 2017]; 1 - the territory of the Red Square; 2 - the territory of the Black Market; 3- the territory of the Green Park

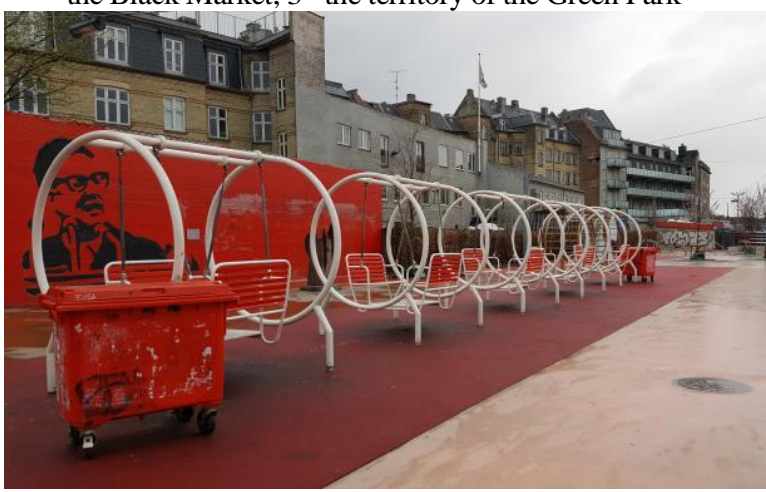

Fig. 5. Objects of the Red Square

[Source: photo by the author, 2017]

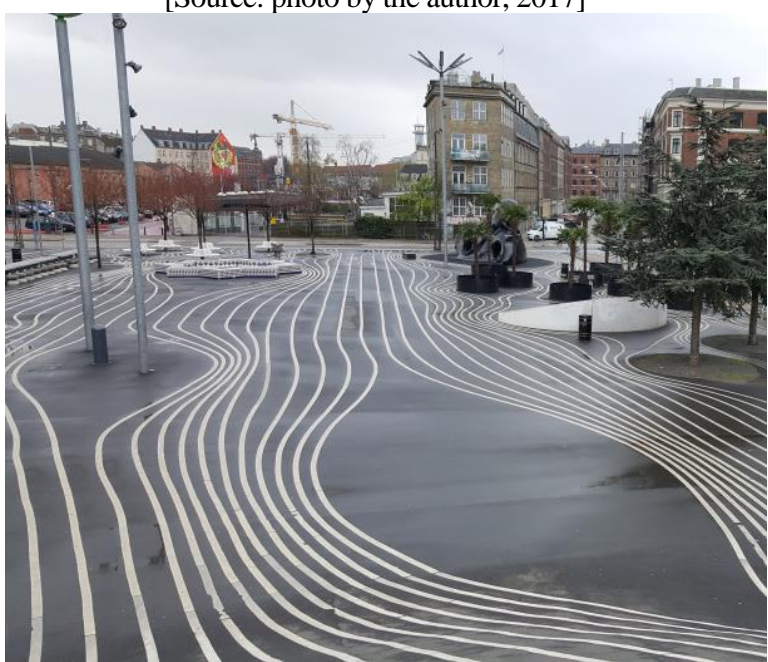

Fig. 6. Objects of the Black Market [Source: photo by the author, 2017]

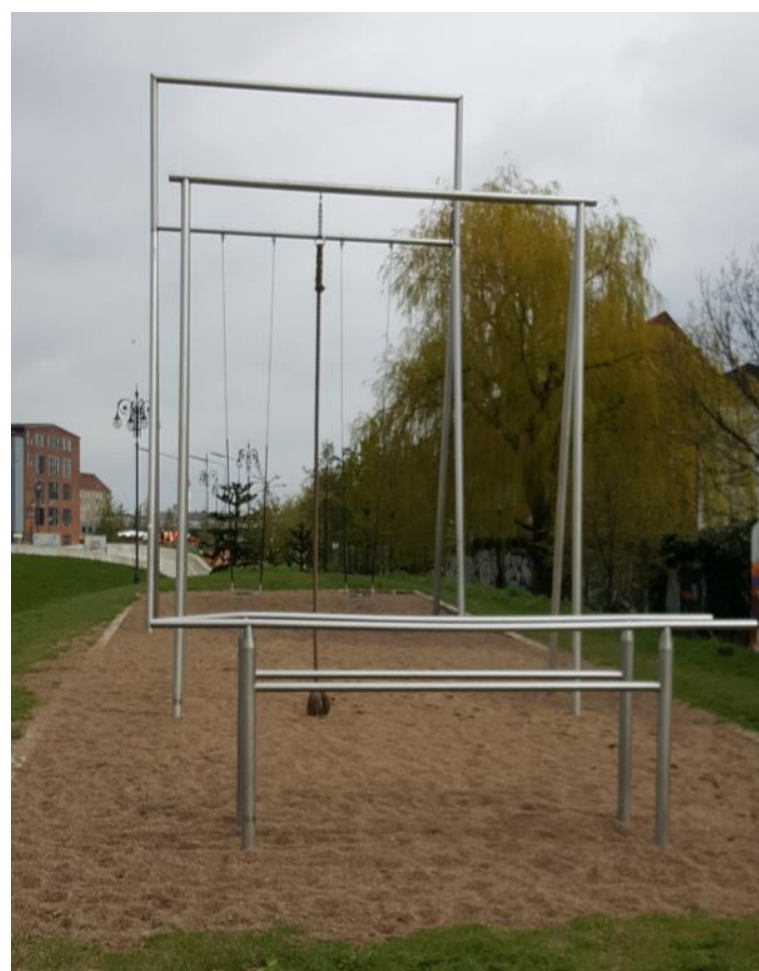

Fig. 7. Objects of the Green Park

[Source: photo by the author, 2017]

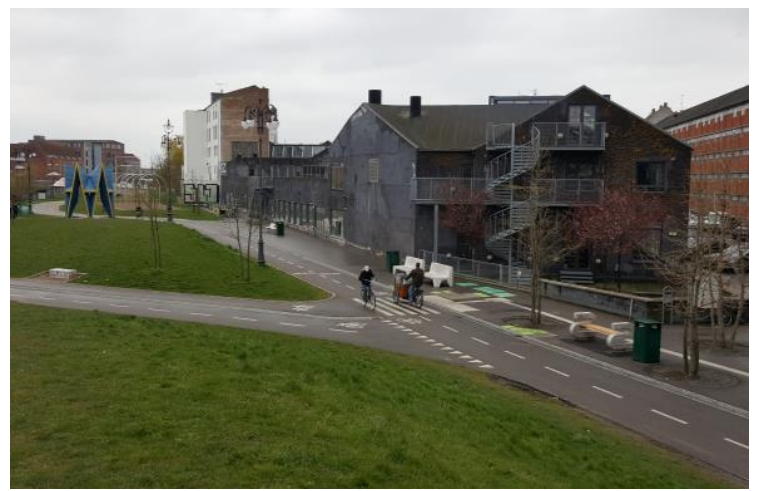

Fig. 8. Bicycle paths in the territory of the Green Park [Source: photo by the author, 2017]

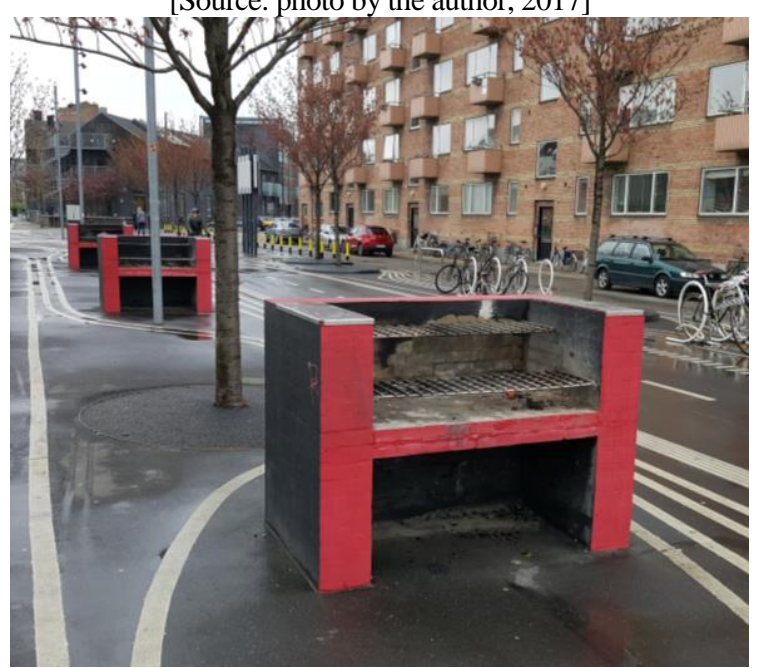

Fig. 9. Picnic places in the public outdoor space [Source: photo by the author, 2017] 


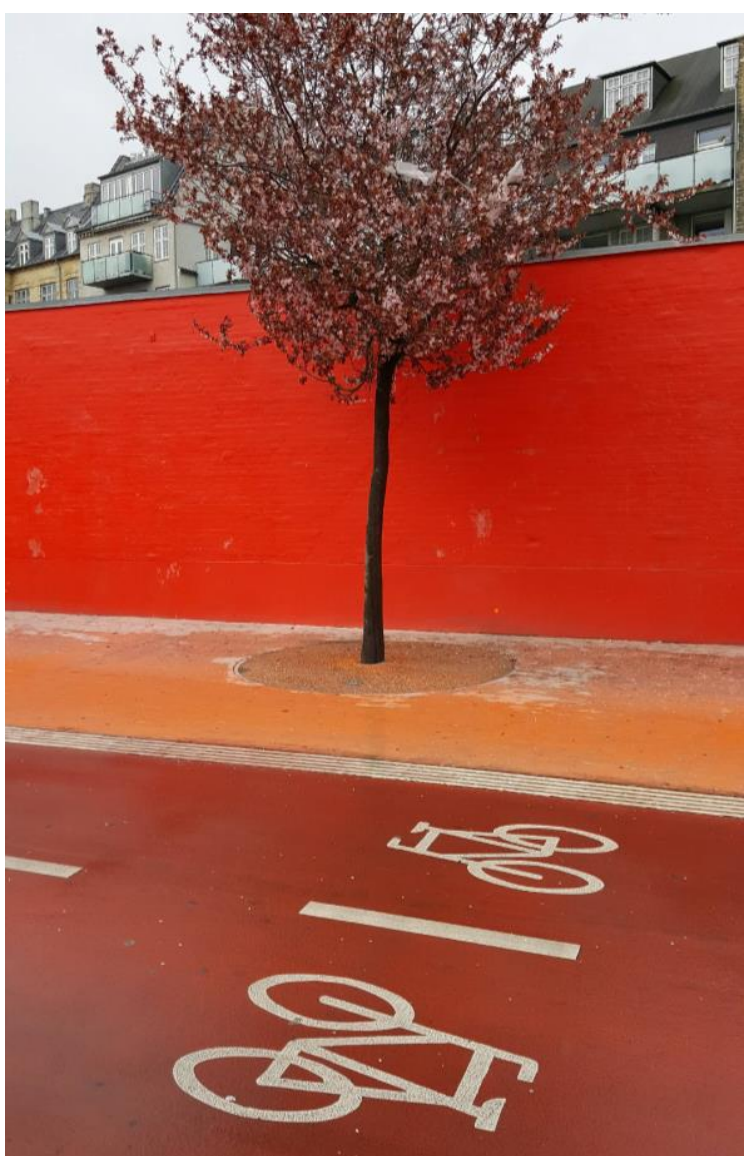

Fig. 10. Contrasting colours of the Red Square

[Source: photo by the author, 2017]

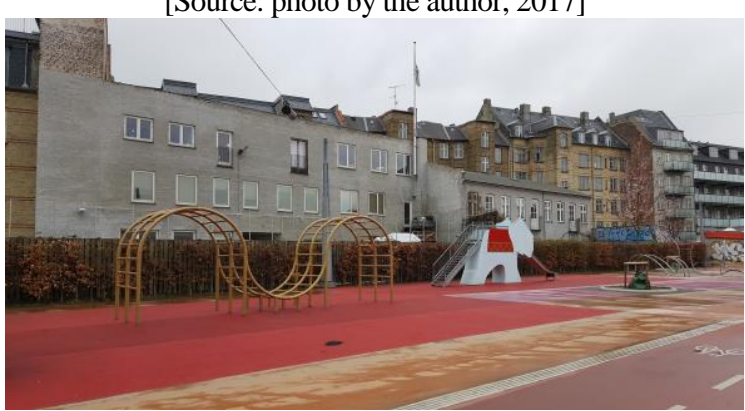

Fig. 11. Attractive objects at the Red Square for different activities

[Source: photo by the author, 2017]

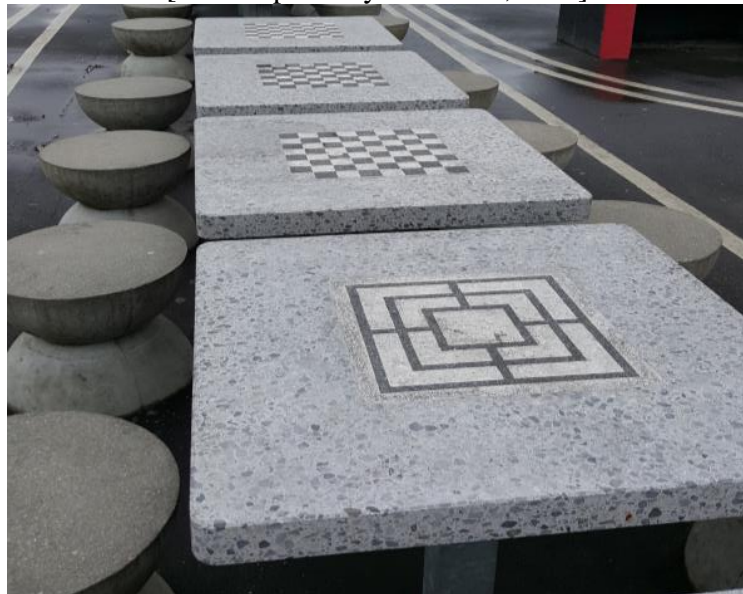

Fig. 12. Chess tables for socializing and recreation in the public outdoor space [Source: photo by the author, 2017]

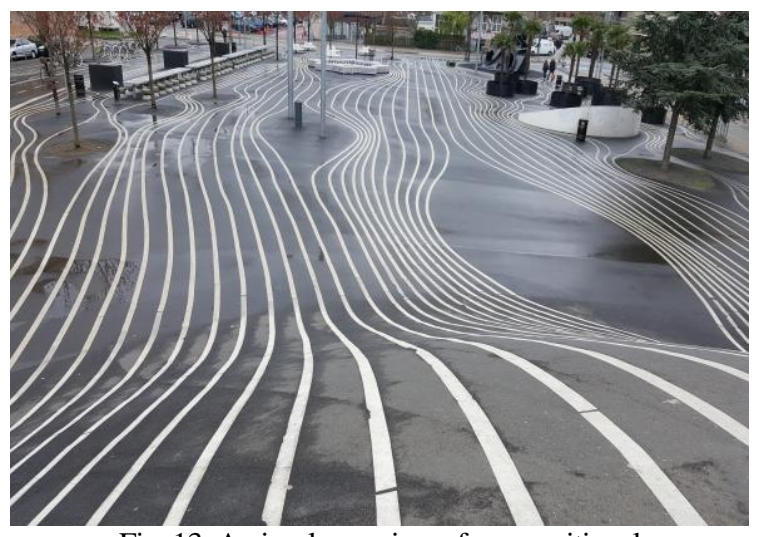

Fig. 13. A visual overview of compositional

harmony for coating [Source: photo by the author, 2017]

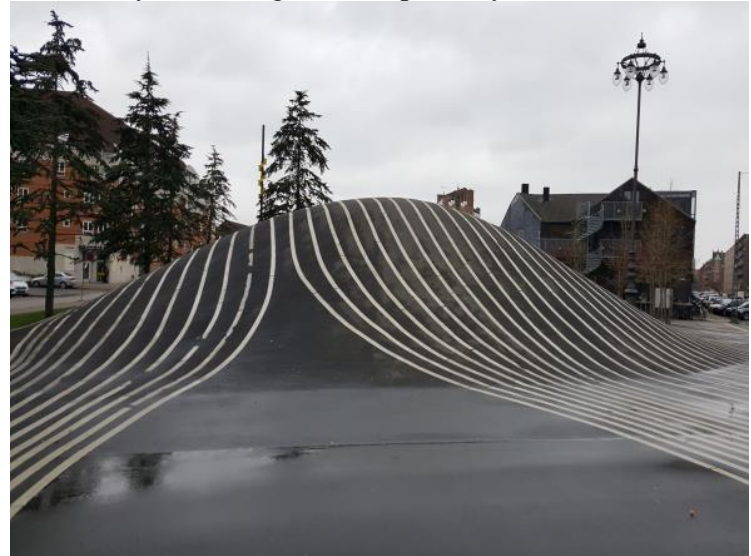

Fig. 14. Elevation - a hill that creates a pleasant touch in the Superkilen Park [Source: photo by the author, 2017]
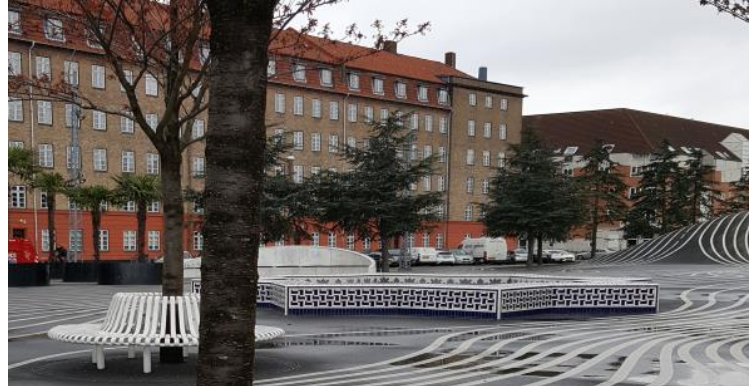

Fig. 15. A blue-tiled water pool, visually associated with warm southern European countries [Source: photo by the author, 2017]

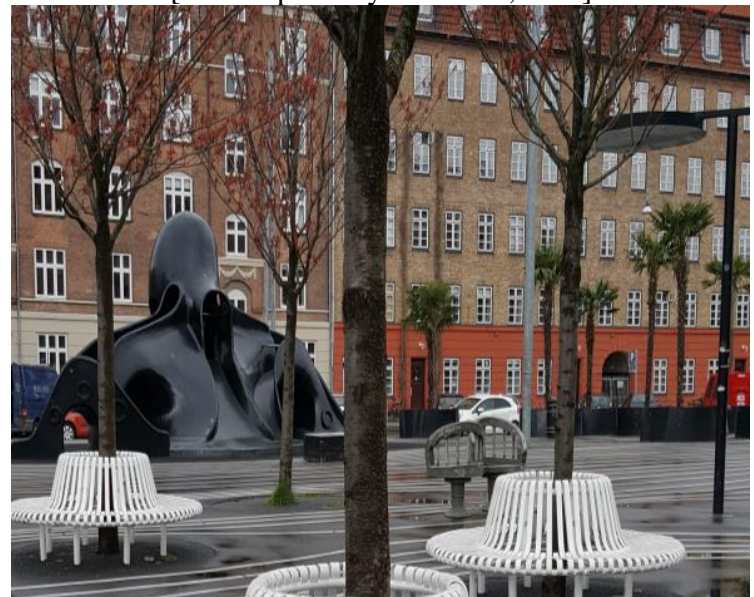

Fig. 16. Use of different species of trees for greenery creating unusual views and accents

[Source: photo by the author, 2017] 
Both hard and synthetic coating features are used in the territory, providing an expressive contrast from the surrounding area. However, The Black Market creates a calm atmosphere, it is part of the park where one can meet other residents and spend time having picnics or playing chess [11], see Figures 12.

A repeating pattern of colours and shapes gives the feeling of order. Repeating lines create harmony [12], see Figures 13 and 14. The white lines on the hard coating create an illusion of movement that visually revitalize this part of the park and leave a completely different impression than from the Red Square. The territory of The Black Market is equipped with various elements of Japanese playgrounds as well as other elements typical of European south that are integrated in this area of Superkilen Park, see Figures 15 and 16. The Green Park is the place where one can have a picnic or walk a dog. There are elevations in the shape of flexible relief, a large lawn and grounds for recreation activities; it is an ideal place where residents can spend their time with families The Green Park's territory contrasts with other parts of the park; there laconic peace and relaxed atmosphere are achieved by means of massive greenery in the urban environment.

\section{Conclusions}

The research gave an evidence that it is possible to create an original design and elements that provide aesthetically beautiful, innovative and attractive recreation place of high quality in urban environment. Careful planning and finding solutions of public outdoor space by means of contrasting, expressive and innovative design elements result in the created place identity of any public outdoor space. Thus Superkilen Park is a positive example that proves the possibility of a different approach to public outdoor space and creates an expressive unity through the use of compositional methods marking new development tendencies in the public outdoor space and landscape architecture on the whole, providing relevant and comfortable public space for each resident of Copenhagen.

\section{References}

1. Treija, S., Bratuškins, U. Development Problems of Large Scale Housing Estates in Riga. Scientific Journal of Riga Technical University: Series 2. Architecture and Urban Planning. Riga: RTU, 2003, Vol. 4, pp. 77-83.

2. Projekts „Ilgtspējīgas lietusūdeṇu apsaimniekošanas sistēmas izveide Latvijas pašvaldībās" (LV2003/005-876/VAPF/0029) ietvaros. Ekonomikas un ekologijas faktori ilgtspējīgai lietusūidenuu apsaimniekošanai apdzīvotās vietās. Jelgava: Jelgavas Tipogrāfija, 2006. 56 lpp.

3. Liepa-Zemeša, M. Topical Dimensional Planning in Cities of Baltic Sea Regiona. Scientific Journal of Riga Technical University: Series 10. Architecture and Urban Planning. Riga: RTU, 2008, Vol. 2, pp. 170-179.

4. Treija, S. Development of Housing Area in Riga. Scientific Journal of Riga Technical University: Series 2. Architecture and Urban Planning. Riga: RTU, 2000, Vol. 1, pp. 58-62.

5. Rīgas pilsētas attīistības perspektīvas starptautiskā kontekstā. Rīgas domes Pilsētas attīistības departaments [online 10.02.2010.]. http://www.rdpad.lv/uploads/rpap/att_plan_izpetes/12_rigas_attistiba_starptautiskaja_konteksta.pdf

6. Biddulph, M. Introduction to Residential Layout. Amsterdam: Elsevier, 2007. 241 p.

7. Gronlund, B. Urban planning for good urban living. Sustainable city of tomorrow. Stockholm: Vasteras, 2005, pp. 31-40.

8. EMBT Arquitectes Associats. Parc de Diagonal Mar. Ultimate Landscape design. New York: Publishing Company, 2005, pp. 33-41

9. Strautmanis, I. Māksla arhitektūrāa. Rīga: Liesma, 1982, 71.-86. lpp.

10. Tisenkopfs, T. Ko nozīmē laba dz̄ive mūsdienu Latvijā? Dzīves kvalitāte Latvijāa Rīga: Zinātne, 2006, 13.-38. 1pp.

11. Lucchese, J. (10.06.2014.) Superkilen: A Public Space to Feel at Home [online 05.01.2017.] http://landarchs.com/superkilen-public-space-feel-home/

12. Vidlunda, S. Énaugi tavā dārzā. Rīga: Jumava, 2009. 120 lpp.

\section{INFORMATION ABOUT THE AUTHOR:}

Una Īle, Dr. arch., Assist. Prof. (since 2012) at the Faculty of Rural Engineers, Department of Architecture and Construction of the Latvia University of Agriculture, 22 Liela iela, Jelgava, Latvia, LV-3001. E-mail: una.ile@llu.lv

Kopsavilkums. Pētījums balstîts uz autora iepriekš veiktajiem pētījumiem par ainavisko kvalitāti un mūsdienu attīstības tendencēm, kas veikti pēdējos gados Skandināvijas valstu mērogā, kur caur iegūtajām atzināām un teoriju tika fiksēti daudzveidīgi publiskās ārtelpas kompozicionālie risinājumi gan Norvēgeijā, gan Zviedrijā, kas rezultātā nosaka un iezīmē mūsdien̄̄gu un êrti lietojamu pilsētvides teritoriju ikvienam tās lietotājam. Rakstā atspoguḷotas aktuālās tendences, kā tiek plānota un risināta publiskā ārtelpa, ṇemot par piemēru Kopenhāgenas pilsētas pieredzi un 2012. gadā atklāto Superkilen parku. Pētījumā konstatēts, ka ir iespējams radīt nestandarta dizainu un elementus, kas spēs nodrošināt estētiski kvalitatīvu, inovatîvu un saistošu atpūtas vietu infrastruktūru pilsētvidē. 


\title{
The compositional and functional study of the Liv fishermen's homesteads
}

\author{
Dace Ržepicka, Aija Ziemeḷniece, Latvia University of Agriculture
}

\begin{abstract}
The clusters of the homesteads of the old Liv fishermen from Cape Kolka to Staldzene keep only some of the mosaic grains from the pride and glory of fishermen's homes which existed until the war. In the $30 \mathrm{~s}$ of the $20^{\text {th }}$ century, the farming and everyday life of the coastal people is marked only by separate outhouses - the cattle-shed, fishing net, boat and firewood sheds, smokehouses, cellars. They are witnessing the bygone farming by the sea as the boats, fishing nets, plank-ways, and people who have the skill to take a boat offshore have disappeared. Today, it is difficult to name settlements as the Liv villages because the number of the disappeared homesteads and lost people in the last 50 years is so huge that it can only be considered as a distant reflection of the situation it was until 1940. Today, this coastline is functioning as an open-air museum, in which the recreation and tourism industry is developing. Only a rare fishing boat slides into the sea at night, landing the fishing nets and collecting them in the morning, so maintaining a still alive skill in fishing and fish processing. Thanks to today's rigorous legislation, small fragments of the historical tradition of farming and building are being slowly recovered. By studying them during the expedition, there is an opportunity to get information about the compositional and functional criteria of the old fishermen's homesteads.
\end{abstract}

Keywords: building structure, compositional solution, cultural and historical heritage, coloring, structure

Introduction

The geographically and economically attractive coastline from Kolka to Staldzene has tempted the political greed of the combatant countries of the early phase of the $20^{\text {th }}$ century, bringing with them the devastations of the two world wars and wiping out the dwelling places of fishermen, carefully built through centuries that told of the Liv management manners and development already from the $14^{\text {th }}$ century.

The next devastating blow to the historical coastal location was given by the Soviet time. With the arrival of collectivization in the 50s of the $20^{\text {th }}$ century and the foundation of fishermen's artels, the usual farming character changed. This is readable in the construction of large-size boats and fishing net sheds (Mazirbe), in the change of the width of road and transport areas along fences (Sīkrags), in the tree clusters in places where even before the war there have been places of dwellings. Only the Sīkrags, Ovīši, and Miķeḷbāka lighthouses proudly stand against the storm and the processes of the political wave rolling. In the $60 \mathrm{~s}$ of the $20^{\text {th }}$ century, collectivization is followed by establishing of the Soviet military bases with the building of underground concrete bunkers in the dunes, bringing with them the ban for fishermen to proceed to sea. Thereby, the historical fishing farm keeping came to an end.

The early $21^{\text {st }}$ century is characterized by the home care to save the remaining and exposing the new to the historic building traditions. Thanks to today's strict laws, each historical place of dwelling is very carefully detailed within the architectural and compositional requirements. After the wave of the war and collectivization, the remaining homesteads create a strange spacing of the historical building. The empty spaces are filled with tree clusters and meadows, so misleading about the former building density, the number of the population, and fishing effort.

After the expedition and categorization of the archival research materials, the research aims to collect the criteria of the historic landscape space and the architectural and compositional structure of outhouses.

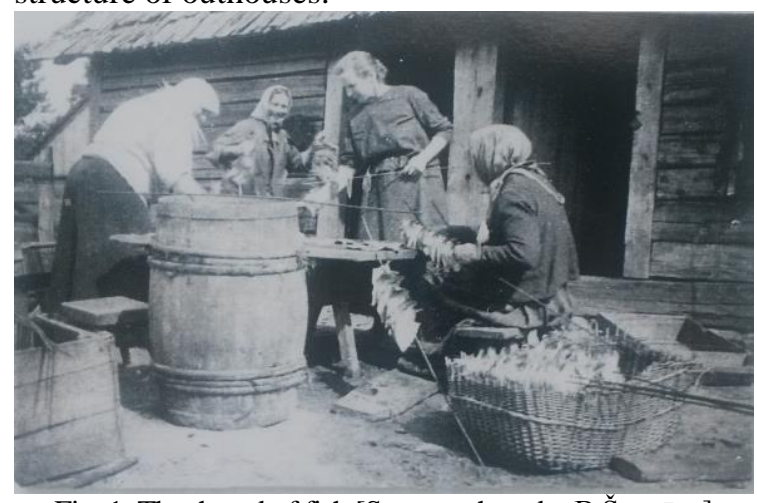

Fig. 1. The thread of fish [Source: photo by B.Suvcāne]

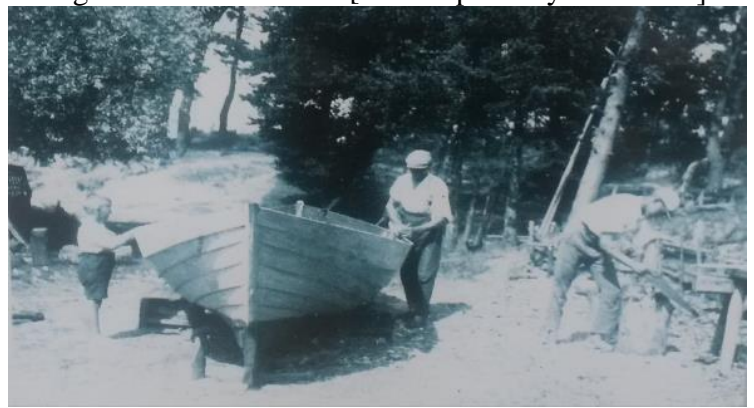

Fig. 2. Construction of boat [Source: photo by. B.Šuvcāne] 
For the assessment of the transformation processes of the coastal fishing villages, several research assignments are to be defined:

- the study of the structure of fishing villages;

- the description of buildings of fishermen's homesteads;

- the position of the old outhouses in the yard.

The summary of the research material is based on the comparative method, using archival materials, obtained from monographs, publications, and interviews with local residents.

\section{Materials and Methods}

From the $14^{\text {th }}$ century, the settlements of Livs on the northern coast of Kurzeme are characterized by the originality of the landscape space, which is not only based on the fishing activity as a functional aspect but also on the peculiarities of the structure of building of places of dwelling. Homesteads as separate small living spaces at the same time served as "production zones" when handling fish, building boats, preparing the lumber, weaving fishing nets. This contributed to a continuous creation of the production area along the coastline, which rapidly expanded in the $20 \mathrm{~s}$ of the $20^{\text {th }}$ century. With a gradual development of craft skills in the making of rowing boats, their number, quantity, and the recognition of good fishing locations increased. Overall, this contributed to increasing of the location of fishermen's farmsteads together. The nature of the fishery is based on the hard conditions of physical work, which is impossible to do by one person - to keep flat the boat in waves, to land fishing nets and to collect the fishing nets or seines and to row. This work requires several men. So, historically, the nature of fishery is reflected in the compositional building structure.

In Europe, at the turn of the $19^{\text {th }}$ and $20^{\text {th }}$ centuries, the boom of the industrial revolution also brought with it the development of the northern coast of Kurzeme. As a bright feature of the Liv villages, 2 aspects of the economic growth are to be mentioned:

in the $20 \mathrm{~s}-30 \mathrm{~s}$ of the $20^{\text {th }}$ century, rowing boats gradually were replaced by motorboats, able to enter deeper into the sea, fishing for about 14-20 km away from the coast (9). It increased catches and the quantity of fish processing, and the need to build ice houses for fish keeping;

the economic boom of the Liv villages was facilitated by the little train line built in 1916, connecting the seaside villages with Ventspils, Dundaga, Talsi, Stende. The highway from the coast to Dundaga served for the fishermen as a good trade route in the inland direction.

Based on the above aspects, it is vividly accompanied by the fishermen's cooperative of the region of Kolka established in the 30s of the 20th century, formed by 9 departments, covering a $60 \mathrm{~km}$

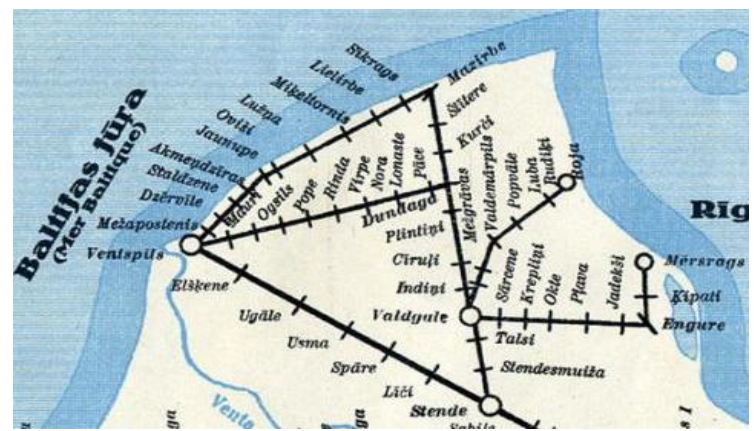

Fig. 3. The dismantled little train track network Stende-Ventspils (1935) [6]

long coastline, providing a certain industrialization of the sector and a better catch,"this region is the place to catch most of our sprats. Naturally, other fish is also much caught there like flounder and herring, also smelt, whitefish, although less"[1]. In the department of the cooperative, there could be common drying rooms, such as the department of Mazirbe where in two drying rooms it was possible to daily "dry around 300000 herrings" [2]. The icefree edge of the sea provided maintenance of a continuous production process throughout the year.

The position of the seaside villages at certain points is not accidental as it is based on the concentration of fish in known places. Going fishing from generation to generation, the deep sea was recognized, where catches were the richest with flounder, herring or sprats. For instance, the best place for the flounder was Lūžna. That's why, in the early $20^{\text {th }}$ century, the number of fishermen dwelling places was very large 38 homesteads [9], where currently only one homestead is left (Fig. 1, 2, 4).

The landscape space of each village has different characteristics of the natural site where the buildings are located in woodland, seaside meadow or slightly rugged nature of places.

The economic trends of fishermen's villages were featured by 4 main landscape spaces, which between themselves created parallelism to the shore:

- the coastline with the fishing net drying on stacks and the sea boat plank-way, leading from the dunes across the beach and the shallow place;

- the dune area that served as a wind barrier for places of dwelling;

- the building zone, where together or in a small distance, fishermen's homesteads are located with a $2 \mathrm{~m}$ wide entrance, leading from the dunes to the homestead;

- behind the building - a forest or cleared land for the fields and pastures.

In the early $20^{\text {th }}$ century, the intensive economic movement was also featured, along with fishing logging, lumber, firewood felling, and trade, since it was sometimes more profitable and gave significant contributions to the farm life. "Mazirbe is located in the farthest corner of the narrow-gauge railway to 


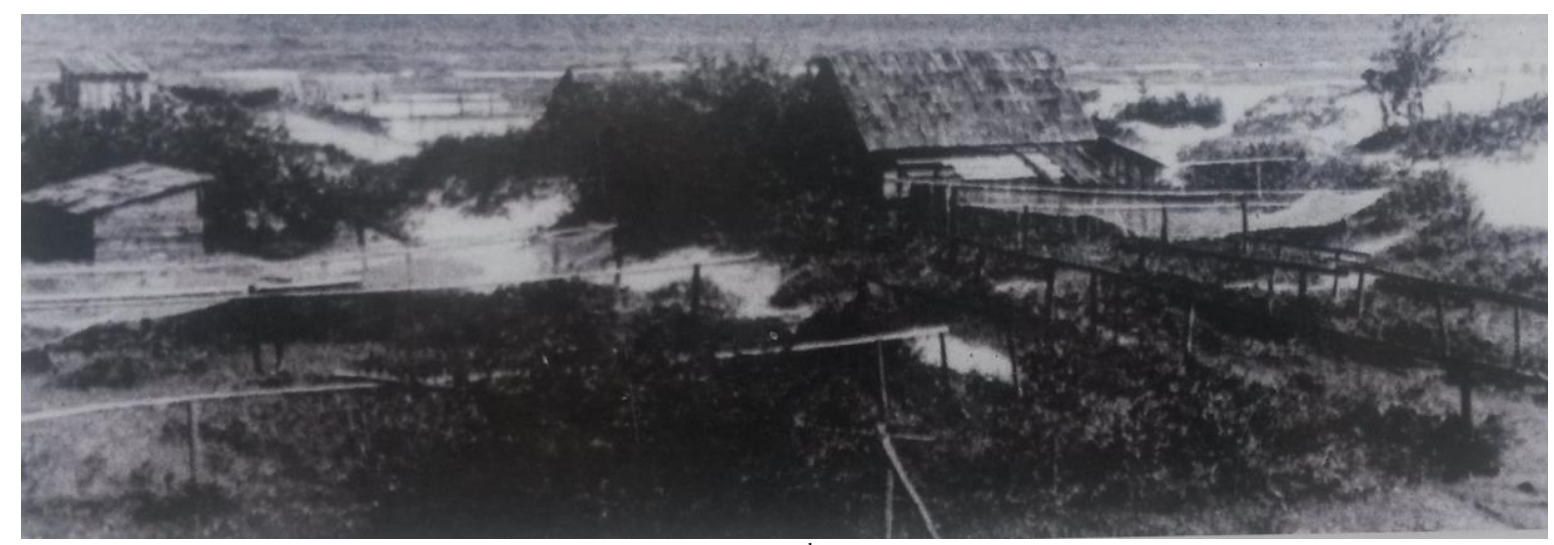

Fig. 4. Barns of the nets in the seashore 30s of the $20^{\text {th }}$ century [Source: Seaside Museum of Ventspils]

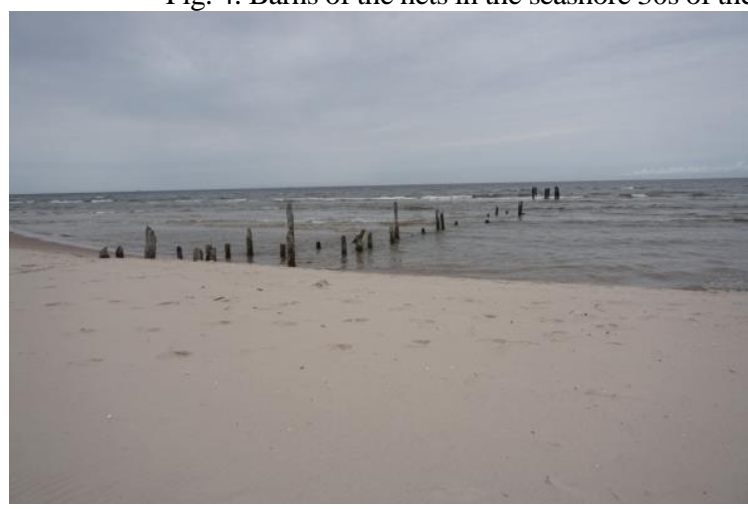

Fig. 5. The boat docks at Mazirbe [Source: photo by authors, 2017]

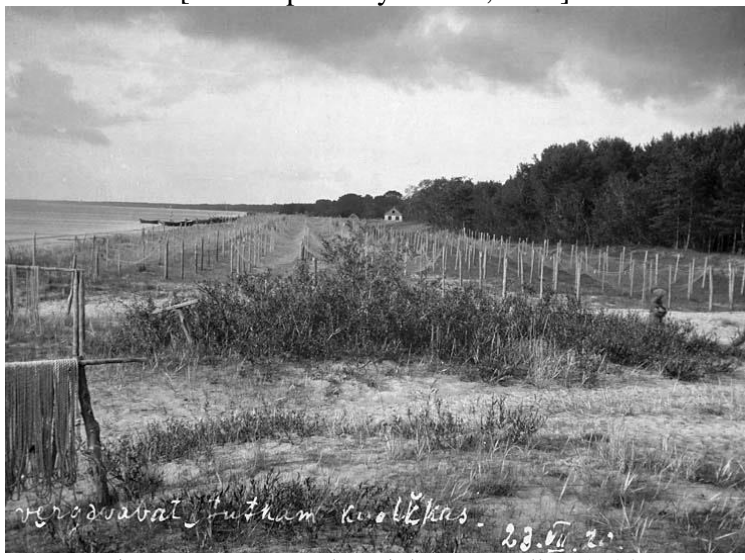

Fig. 6. Net on wooden pickets at Kolka (1920)

[Source: http://www.nba.fi/liivilaiset/Latvia/144/20La.html]

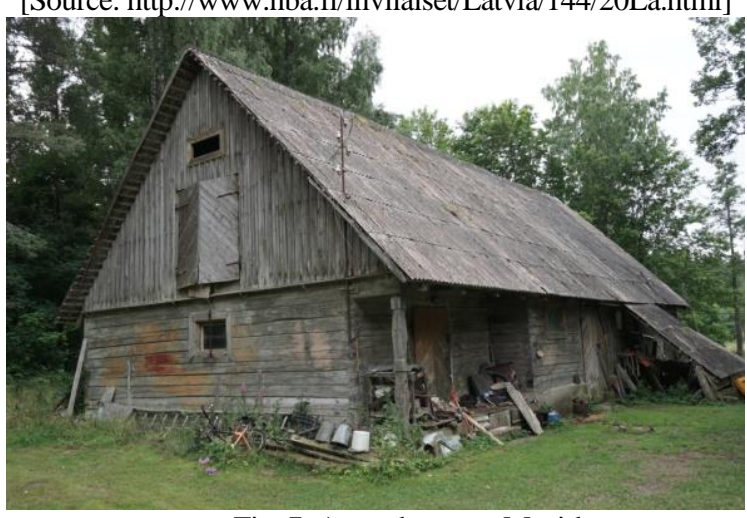

Fig. 7. An outhouse at Mazirbe

[Source: photo by authors 2017]

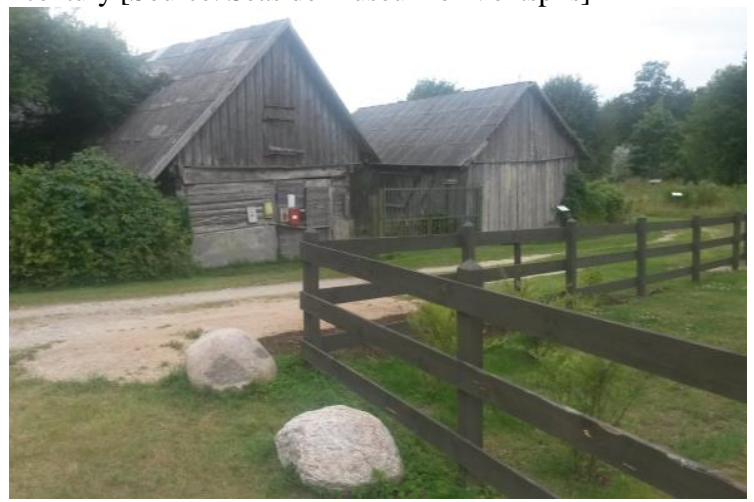

Fig. 8. A fishing net barns at Sīkrags

[Source: photo by authors 2017]

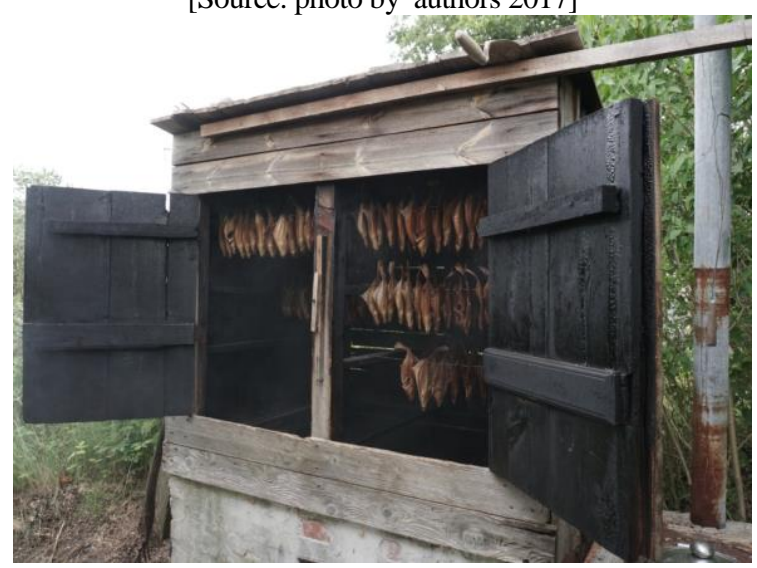

Fig. 9. Fish smoking at Mazirbe

[Source: photo by authors 2017]

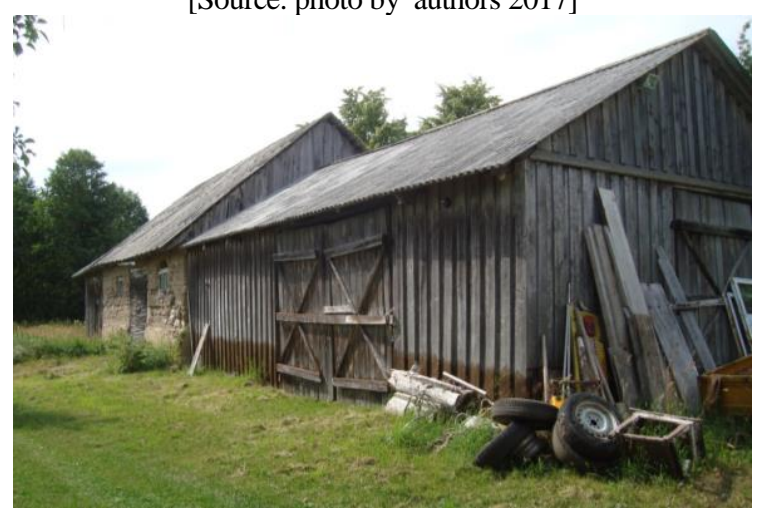

Fig. 10. Cattle-shed and a barn at Sīkrags

[Source: photo by authors 2017] 


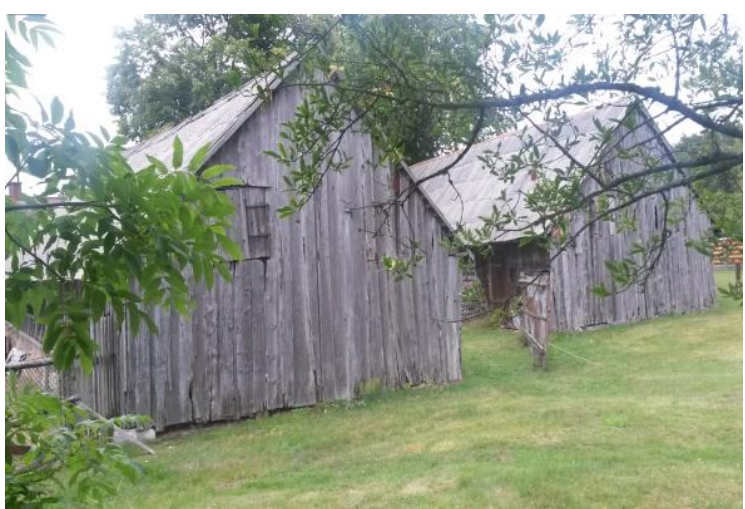

Fig. 11. Barns of the fishermen's homestead at Staldzene [Source: photo by authors 2017]

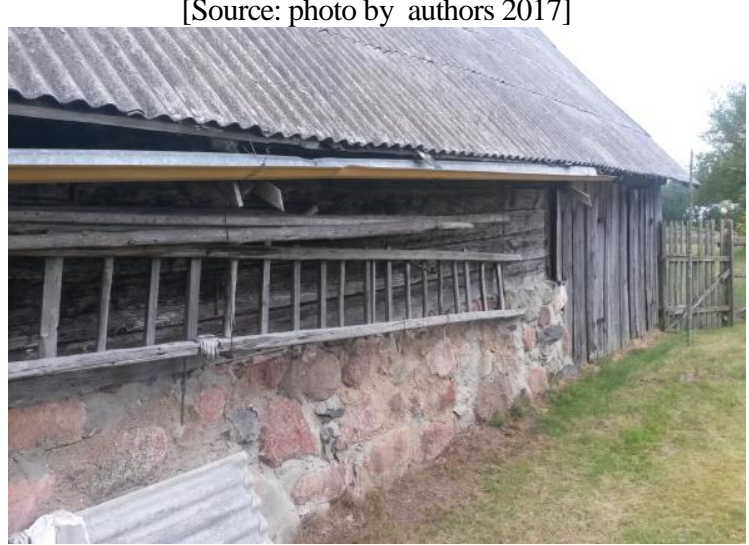

Fig. 12. Deep cattle shed at Sĩkrags [Source: photo by authors 2017]

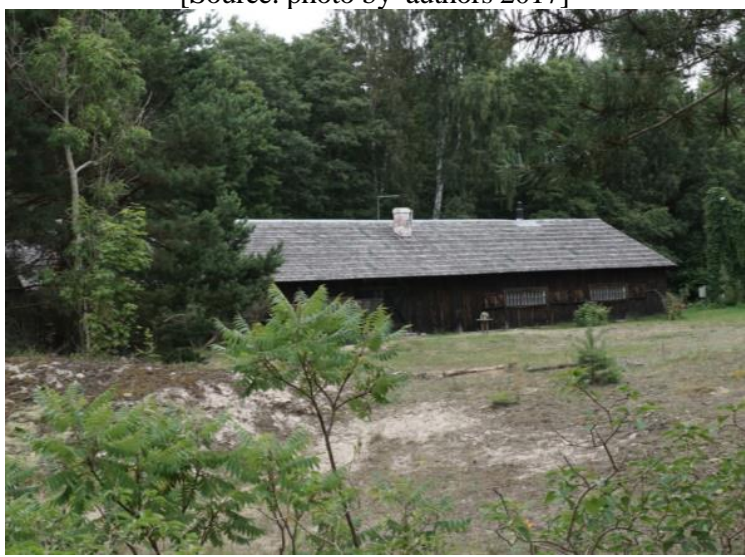

Fig. 13. Fishing net shed at Mazirbe

[Source: photo by authors 2017]

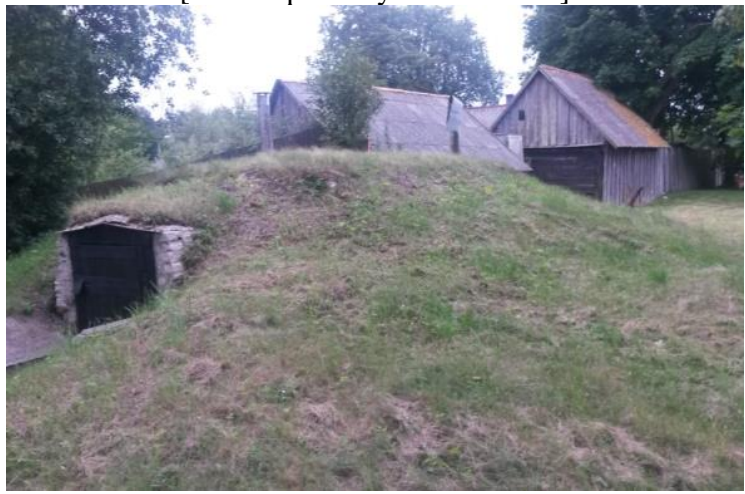

Fig. 14. Cellar and barns at Staldzene

[Source: photo by authors 2017] the north. From here, on both sides, the railway bends back along the seaside to Ventspils, in the middle of the land through the forests and Dundaga, Talsi, Stende. This corner of the railway has a big role due to the large forests of Cape Kolka. And the folks of Mazirbe say that in the forest they are earning more than the land and fishing can give them. They fell, carry, and load in wagons" [3].

The homesteads are distinctive by the location of the building in a flat place. On the slopes, fish and vegetable cellars were installed. At the fishermen's homestead, there was a dwelling house, barns for hay, the boat and fishing nets, firewood, a smoke house, a cattle-shed, a well, which grouped around a wide inner yard. Similarly, as the peasants managed domestic farming, the dwelling house was aside of the cattle-shed in the fishermen's homesteads as well, so that the sea wind could not bring the smells of the cattleshed in the living place.

The dwelling house was made of wood with a shingle roof, usually of wooden stands, cladding the exterior wall with horizontally placed boards. Between the foundation and the windowsill line boards were frequently placed vertically, keeping such belt between the beam and the wall plate place as well. Cattle-sheds were built from logs or wooden stands, basing them on a high stone foundation, forming the so-called deep cattle-sheds. Along the stone foundation, the manure was kept inside during the winter so that with the start of grazing to leave them on the field. Barns served for keeping the wood, hay, boats, and fishing nets (Fig. 5, 6). They are wooden with vertical boards, based on a small stone foundation. As one of the typical colorings is the black tone, historically using the wood tar. When boats were tarred, the exterior walls of buildings were also tarred.

For the homesteads that were located nearer to the dunes, the longest side of the barn was built parallel to the sea shore to get less wind in the yard. Two adjacently placed barns with the long sides are also visible, where the outside barn protects the inner side barn from gusts of the wind (Staldzene, the two parallel barns at Sìkrags).

In the early $20^{\text {th }}$ century, the old boats mounted vertically were adapted to fish smokehouses. This peculiar application creates the language of form creation, which describes the Liv villages.

\section{Results and Discussion}

After the collection of the archival materials, the information obtained with the comparison method is used during the expedition (July 2017).

Researching the transformation processes and summarizing the effect of the social and political 
features on the cultural and historical territory, they are broken down into 3 main defining criteria:

- the change of the ethnic identity, brightly characterized in the monograph, "Still in the middle of the $19^{\text {th }}$ century, the northern coast of Kurzeme was inhabited by only the Livonians (Livs). They referred to themselves as "rāndalist" - the coast dwellers. At Jaunciems, Mazirbe, Košrage, Pitrage, Saunags, Kolka, and Melnsils, only the Livonian language was heard. Latvian was spoken on the "hill" - above the Slitere Blue Hill bluffs, away from the sea. The Latvians tended livestock, the Livs were mostly engaged in fishing, as the coastal soil was sandy and lean. In 1810, in the above mentioned Livonian villages, there were almost 500 sea fishing boats. The whole fleet! And in every village, there was at least one "koploja" - a large trade boat for longer journeys. Firewood and other goods were transported even to St. Petersburg. The Livs also worked as commercial intermediaries, for instance, on the "hill" purchased honey and wax to favorably sell it in Riga. It is not surprising that "randalisti" were more prosperous than the Latvians" [7].

- the economic identity;

The last 100 years in the development of the coastal villages reached the culmination of development and misery, performing a destructively painful somersault. The unique cultural landscape is irretrievably lost, only rare witnesses are left behind about the presence of the fishery on this sea coast. In the early $20^{\text {th }}$ century, the homesteads actively involved in fishing with the provision of the sector-specific buildings, farm tools and equipment, including the fishing net drying on the stacks in the dunes, boat docks on the sea coast, which generally created a highly unique, distinctive cultural landscape of the fishermen's villages and lively environment.

- The development of tourism infrastructure in the early $21^{\text {st }}$ century.

By the data collected, in the $30 \mathrm{~s}$ of the $20^{\text {th }}$ century, it is possible to compare the number of the fishermen's homesteads; Lūžna -38 , today - 1 [9]; Miḳeḷbāka - 55 homesteads, today 7 [9]; Jaunciems - 17 houses and a number of motorboats [9].

Mazirbe - a Livonian center where in 1937 there were 249 residents and 50 of them spoke in the Livonian language. The starting point of converting into the Latvians.

In the village, there is the railway station, an elementary school, the district doctor, the post and telegraph office, a ranger, a steam mill with a sawmill, a brickyard, a pharmacy, some outlets, the Lutheran Church, a pastor, and 256 residents" [4].

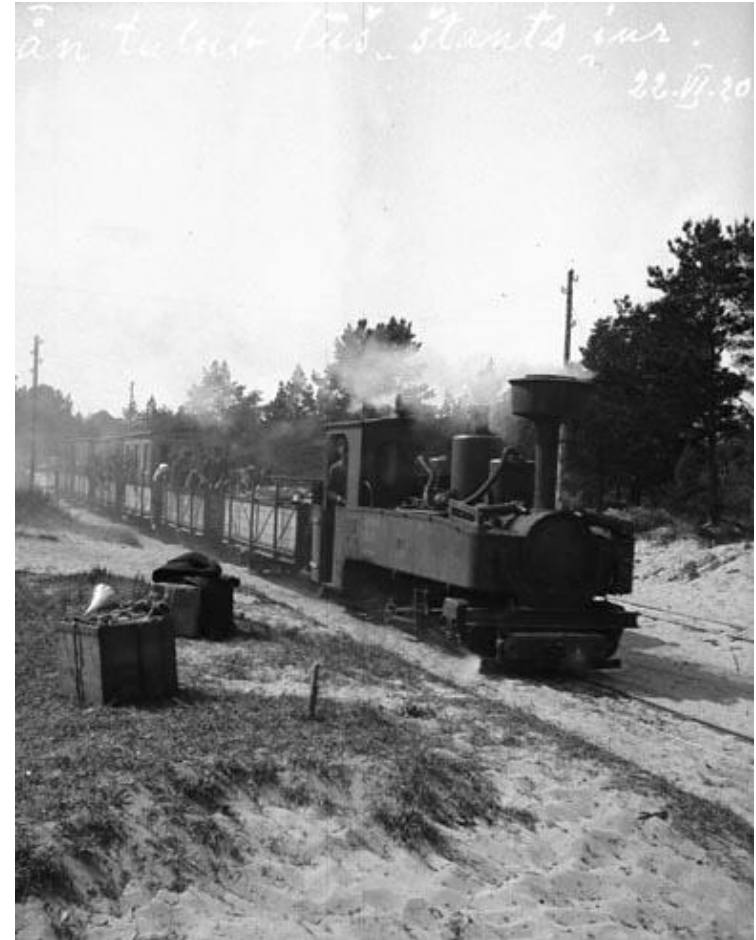

Fig. 15. Little train, 1920. g.

[Source: http://www.nba.fi/liivilaiset/Latvia/144/007La.html]

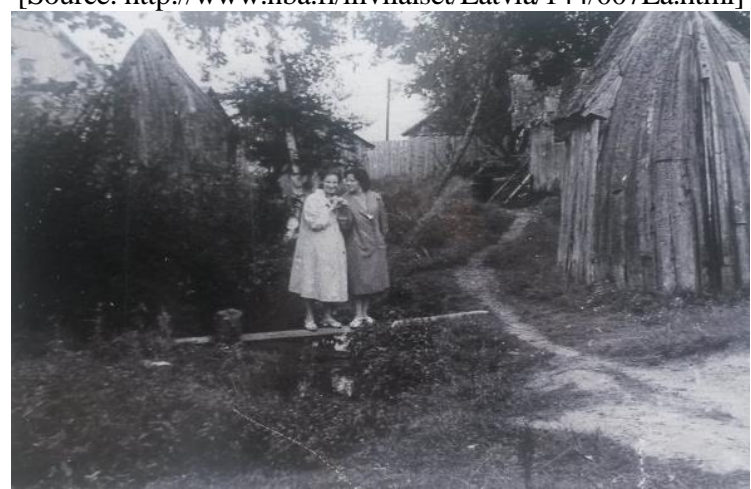

Fig. 16. Old boats as drying house

[Source: photo by V. Dzene]

Lielirbe - 60 houses, 5 phones, 20 and more different boats, fishing net huts in the dunes, two or three lead ropes, lamprey weirs.

Sīkrags - in documents as a village mentioned already in 1387 . During the $17^{\text {th }}-18^{\text {th }}$ centuries, one of the most significant small ports on the northern coast of Kurzeme [9].

Košrags - 110 residents, of which 10 fishermen, a motorboat, an open-sea boat, a jetty.

Founded in the $17^{\text {th }}$ century and even in 1680 as the only homestead in Košrags - the homestead "Kūkiņi" is mentioned. In 1826, at Košrags there were 78 residents; in 1932, the construction of the port was organized, in 1938, a jetty for the collection of mud (sea manure) [5].

Pitrags - in historical sources is first mentioned in 1582 . In the middle of the $19^{\text {th }}$ century, a pub was opened at Pitrags. In the early $20^{\text {th }}$ century 12 farms which have belonged to generations of 
farmers, 38 fishermen's holdings, 2 motorboats, several sailing boats, many row boats. It was intended (around 1938) to build a fishermen's shelter port in the estuary of the river at Pitrags.

In the $19-20^{\text {th }}$ centuries, Pitrags was known as a major boating and shipbuilding center, which essentially contributed to the socioeconomic development of not only the village but also of all the sea coast. In the Soviet times, a fish-smoking factory was built at Pitrags.

Saunags - in the historical sources for the first time mentioned in 1310. In 1826, in each homestead, there were 16-17 people, together around 60 people. In 1938 - 5 motorboats, 3 sprat salting tubs. Vaide - in 1935, 106 people lived there. Nowadays, the development of the Liv coast is affected by several factors:

1.The fishing industry in Latvia, since joining the European Union, is regulated by the set fishing quotas in fishery and the Fishery Law (in force since May 12, 1995). Unfortunately, the rapid reduction of fish resources in the Baltic Sea and the fishing quotas set by the European Union do not sufficiently provide the fishermen with work and income, thus not contributing to renewing of the fishery-related cultural landscape on the Livonian coast.

2.The benefit in the sphere of nature protection is positively celebrated - the silenced economic activities and the closed, military regime of the area in the Soviet years allowed to maintain relatively intact natural environment to the present days and around 860 different species of rare plants, the diversity of which was formed due to the particularly mild climate of North Kurzeme, for instance, the yew and the Baltic ivy.

3. The dismantled little train track network and most of the railway stations are thelost opportunity for the tourism industry. The maximum total length of the railway during its existence (1916-1963) reached 280 kilometers. Later, the little train lines were also used for the carriage of passengers and for a long time it was the only means of traffic along the seaside villages of Kurzeme.

\section{Conclusions}

The farming culture of the $14^{\text {th }}$ century brought by the Livonians at the seaside has given a great contribution to the cultural and historical heritage of North Kurzeme up to the early $20^{\text {th }}$ century. Its uniqueness is based on the historic nature of farming and the structure of farm building, which was the subject of both the natural area and farming peculiarities.

Thanks to the modern strict legislation for determining the threshold of the criteria in architecture and construction in the Slitere reserve, the start of restoration of the homesteads of the historic coastal building is noticeable in the last ten years. This applies not only to the dwelling houses but also to the historical identity searches of the old outhouses, the fence, and the inner yard area. As the next step at the municipal level is to be mentioned the amount of work for the recovery of the historical functional identity of the coastal landscape space - fishing net huts, fishing net drying on stakes, wooden docks. By starting the restoration of the old elements of the fishermen's farming environment on the sea coast and in the fishermen's homestead building, the started restoration work of fishermen's homesteads would be continued. It is not sufficient to base the revival of the historical landscape space only on the funding opportunities of private operators. It requires a serious financial support of the program developed by national institutions.

As it is previously mentioned, in the $21^{\text {st }}$ century, the new mansion building in the village of fishermen, identical in the historical scale and coloring, can recover identity to attract tourism infrastructure in North Kurzeme. The collected materials of the research are the starting point of the architectural form creation and the understanding of the compositional language of the building in recovering the historic area.

\section{References}

1. Dubiṇšs, E. Kurzemēe. 1993. g., Rīga: Preses nams, 1993., pp. 100.-101.

2. Dubiņš, E. Kurzemēe. 1993. g., Rīga: Preses nams, p. 98.

3. Dubiņš, E. Kurzemē. 1993. g., Rīga: Preses nams, p. 97.

4. Dubiňš, E. Kurzemēe. 1993. g., Rīga: Preses nams, p. 96.

5. Kurzeme. Rīga: Latvijas enciklopēdija,1993., pp. 86-89.

6. https://lv.wikipedia.org/wiki/Stendes\%E2\%80\%94Ventspils_lauku_dzelzce\%C4\%BCi

7. Pope, A. Burinieku gadsimts Latvijā. Rīga: Zinātne,1989., pp. 21.-22.

8. Šuvcāne, V. M. Mazirbe - mazs ciems Jürmalā. Rīga: Jumava, 2006., p. 164

9. Šuvcāne, V. M. Lībiešu ciems, kura vairs nav. Rīga: Jumava, 2002., p. 490.

\section{INFORMATION ABOUT AUTHORS:}

Dace Ržepicka. Mg.arch., phD Student in Latvia University of Agriculture, Research on the industrial heritage of the Baltic Sea coast. E-mail: dace.rzepicka@inbox.lv

Aija Ziemel̦niece. Dr.arch. A. Ziemelniece is an prof. in Latvia University of Agriculture, specialized in fields cultural heritage, Study of transformation processes of rural landscape. E-mail: aija@k-projekts.lv 
Kopsavilkums. 14. gs. lībiešu nestā saimniekošanas kultūra piekrastē līdz 20. gs. sāk. ir devusi spēcīgu kultūrvēsturisko mantojumu Ziemeḷkurzemei. Tās savdabības pamatā ir vēsturiskais saimniekošanas raksturs un sētu apbūves struktūra, kas bija pakḷauta gan dabas pamatnes, gan saimniekošanas īpatnībām. Zvejnieku sētas kā atseviškas nelielas dzīves telpas reizē kalpoja kā "ražošanas zonas", apstrādājot zivis, būvējot laivas, sagatavojot zāğmateriālus, aužot tīklus. Minētais veicināja vienlaidus "ražošanas" teritorijas izveidošanos gar piekrasti, kas īpašu uzplaukumu ieguva 20. gs. 20.-30. gados. Pamazām attīstoties amata prasmei airu laivu izgatavošanā, pieauga gan to skaits, gan nozvejas daudzums, gan labu zvejas vietu atpazišana. Kopumā tas veicināja aizvien blīvāku zvejnieku sētu novietojumu vienkopus. Zvejniecības specifikas pamatā ir smagi fiziskā darba apstākḷi, ko nav iespējams veikt vienam - viḷnos noturēt līdzeni laivu, izmest un izcelt tīklus vai vadu un airēt. Šim darbam ir nepieciešami vairāki vīri, kas vienlaikus varēja doties jūrā. Zvejas darba specifika labi atspogulojas ciemu apbūves kompozicionālā uzbūvē - blīva apbūve ar tīklu būdu novietojumu liedagā un aiz kāpām, vairāku šķūṇu novietojums sētas pagalmā paralēli, kuriem cieši garām ved cel̦š pāri kāpām. Kūts vai šķūņu jumtu slīpnes, to augstums, šķūnu platums un to distancējums tika ievērtēts, zinot valdošā vēja virzienu un aizvēja vietas, pagalma lielumu, zivju žāvēšanas būdu novietošanas vietas, cel̦š no kūts uz ganībām, ledus pagrabs kāpas nogāzē utt.

Pētot transformācijas procesus un apkopojot sociālo un politisko iezīmju ietekmi uz kultūrvēsturisko teritoriju, ir iedalāmi vairāki situāciju raksturojošie pamatkritēriji: valsts politiskā nostādne, etniskās identitātes maiņa, saimniekošanas tradīcijas, tūrisma infrastruktūras attīstība 21. gs. sāk.

Lībiešu piekrastes kultūrvēsturiskās saimniekošanas atgūšanu mūsdienās ietekmē vairāki faktori:

1. Zvejniecības nozari Latvijāa kopš iestāšanās Eiropas Savienībā, reglamentē zvejniecībā noteiktās nozvejas kvotas un Zvejniecības likums (spēkā kopš 1995. g. 12. maija). Zivju resursu straujā samazināšanās Baltijas jūrā un Eiropas Savienībā noteiktās nozvejas kvotas, kas, diemžēl, nepietiekami nodrošina zvejniekus ar darbu un ienākumiem, tādējādi neveicina ar zvejniecību saistītās vēsturiskās kultūrainavas atjaunošanos lībiešu krastā.

2. Dabas aizsardzības prasības - apklusinātā saimnieciskā darbība un teritorijas noslēgtais, militārais režīms padomju gados ḷāvis saglabāt līdz mūsdienām salīdzinoši neskartu dabas vidi, un ap 860 dažādas reto augu sugas, kuru daudzveidība izveidojusies pateicoties Ziemeḷkurzemes īpaši maigajam klimatam, piemēram, parastā īve un Baltijas efeja.

3. Kā pazaudēta iespēja tūrisma nozarei ir demontētais mazbānīša sliežu tīkls un lielākā daḷa dzelzceḷa staciju, kas vēsturiski kalpoja zvejnieku saimnieciskās dzīves uzturēšanai.

Pateicoties mūsdienu aizsāktajai stingrai likumdošanai arhitektūras un būvniecības kritēriju noteikšanai Slīteres rezervātā, ir pamanāms pēdējo desmit gadu laikā veco piekrastes zvejnieku sētu atjaunošanas aizsākums. Tas ir attiecināms ne vien uz dz̄̄vojamo ēku, bet arī uz veco saimniecības ēku, žoga un iekšpagalma teritorijas vēsturiskās identitātes meklējumiem. Kā nākošais solis pašvaldības līmenī ir minams aizsākums krasta ainavtelpas vēsturiski funkcionālās identitātes atgūšanai - tīklu būdas, tīklu žāvējamās vabas, koka steḳi. Tam ir nepieciešams nopietns valsts institūciju izstrādātas programmas finansiālais atbalsts. 


\title{
The non-implemented vision "Karosta - Culture Port"
}

\author{
Santa Valiivahina (Mazika), Liepaja University, Art Research Laboratory
}

\begin{abstract}
Founded in 2000, "K@2" was one of the first independent cultural centers in Latvia which after regaining of independence in the second half of the $90 \mathrm{~s}$, in the search of an alternative expression of space, was begun to be established by the new artists. Not intentionally but logically these phenomena are included in the innovative context of the institutionalism, new in the cultural space of Latvia but applied since the 70 s of the $20^{\text {th }}$ century.

For several years, there worked two artists who invited their colleagues both from Latvia and foreign countries to create exhibitions, run cinema lectures, implement workshops for the youth of Liepāja Karosta and Liepāja in the sound art, photo, video, and other areas. During their operation period, "K@2" filled the niche between the artists, residents, and politicians, as well as worked in the areas which at that time were not even topical - the open access Internet, the book, video, and audio record library and the reading room, as well as the representation of the municipality in the "housing segregations" of the city, free courses of the Latvian language, games room for children, etc..

But the constant "survival conditions" denied a long existence of the center, leading to the closure at the time when its legitimacy was recognized at the national level. But the ideas nursed at Karosta still continue to live and thrive.
\end{abstract}

Key words: contemporary art, new institutionalism

\section{Introduction}

Nowadays, the cultural institutions live in a "gap" between the awareness of the gallery and private space. Here, you can no longer talk about the "contemporary art" as something elitist. Art provokes and creates preconditions for the encounter between artists, local residents, politicians, etc.. Since the 90 s of the $20^{\text {th }}$ century, the new cultural organizations were one of the first which not only talked about but in their operation also implemented the strategy of art, education, information exchange, and accessibility among not only the stakeholders and representatives of subcultures but also among national minorities, emphasizing the originality and value of each culture.

One of such institutions was "Cultural and Information Center K@2” (“K @ 2”, 2000-2008) at Liepāja Karosta (Fig. 1). The center was founded in the middle of the former military area when from a closed zone Karosta became the urban social ghetto district, inhabited mainly by non-citizens and socially disadvantaged families but tourists, driving through it by buses, feared to stop and get out and looked at local people and their environment as to something exotic, however dangerous for a closer communication.

The purpose of "K@2" was to promote positive changes in the society with the help of art, culture, education, integration, and cooperation, creating an alternative to the situation that existed in this location before.

The article aims to look at some "K@2" activities and ideas in the context of the social development of Karosta linked to the center's

activities in the field of visual art where the secular art gallery "K. Māksla?" has been operating the longest. In parallel, an issue will be raised on the role of art in the rehumanization of the region's social environment and the alternative strategies which it offers. Therefore, within the framework of this article, separate exhibitions in the gallery looking for this strategy are mentioned but given the amount of the material, in this direction, the study has yet to be continued.

\section{The searches of an Alternative form and content in Latvia in the $90 \mathrm{~s}$ of the $20^{\text {th }}$ century and "K2"}

The major political changes that have taken place over the Baltic States in the last two decades have also affected art and its manifestations. Alongside, the traditional institutions of art, the young artists create independent alternative premises to be able to work in places with which they want to be linked, without going to the already established centers and not subject to the dictates of the market.

At the national level, outside the focus and attention of the official institutions, for a long time, there have been a string of regional and social structures, practicing a peculiar policy of isolationism. This vacuum is filled with selforganizing creative units, characterized by an interdisciplinarity, amorphous structure, and flexibility. Often, such own-initiative participants do not identify themselves as artists, perceiving their activities as an organic component of such a lifestyle and freely drift between music, literature, and visual 
culture. The examples include the text group Orbita, the RIXC Center for New Media Culture, the Latvian New Theater Institute, etc..

These organizations deal with art and cultural issues, therefore they may be involved in other independent political or social activities. Such groups of artists have often become a springboard of art creating. There, artists have developed alternative strategies to deal with a variety of issues related to building institutionalism to test the relations and interactions of art and the society as well as to reflect on the role of art in relation to globalization, etc..

It is possible that the quest for legitimacy distinguishes this movement from the "underground" culture of the mid $20^{\text {th }}$ century, from extreme alternativism or even the desire to run a marginal position. Strengthening of the legal status is necessary not only to raise funds which is one of the priorities but just as important is to build a formal representation. As demonstrated by practice and the example of "K@2", then by an active involvement of the organizations of the new institutionalism in the implementation of the purpose of the cultural policy, the national legislation may also be affected in the interests of the nongovernmental sector.

The scholar Nina Mentmane sees an interesting analogy of the new institutionalism within these organizations that have been established in the $90 \mathrm{~s}$ of the $20^{\text {th }}$ century. Assuming that in relation to the European Center, Latvia has reached separate phenomena and trends with some lagging behind the said can also be applied to "K@2". The scholar concludes that the purpose of the "institutions that were established or restructured in the 1990s, was not to establish an independent working or belief pattern. In the creation of their image, the individual or the independent curator, who largely assumed responsibility for their profile, was very important. If the curator changes, the organization itself also changes" [1]. In this context, the role of the personality is actually accentuated rather than the environment in the development of the specific processes. Similarly, "K@2" was based on personalities "from the outside" who were creatively inspired by the environment of Karosta.

"K@2" as any non-governmental organization attracting financial resources on the basis of implementation of projects, operated in the non-profit status [2]. In addition to the independence guaranteed by this status and the inevitable financial insecurity, the liberty of contents came. It was one of the main reasons why " $\mathrm{a} @ 2$ " and the leaders of similar organizations voluntarily accepted and still accept this lifestyle, creating an alternative to the mass culture.
In the middle of the $80 \mathrm{~s}$ of the $20^{\text {th }}$ century, the sociologist Paul DiMaggio wrote that "the awareness of the cultural differences and mass entertainment appeared only with the establishment of non-profit organizations" [3] The inclusion of certain art forms in these organizations did not request the indulgence to the market demand and preconditions. This explains the difference between the methods of profit and non-profit activities and why in the field of the Western culture in the spheres of creation and distribution, the non-profit status is lately becoming increasingly common. The scholar stresses that not so much the economic indicators as the diversity of the attracted audience suggests of the significance of the institution.

Within the new institutionalism, a variety of strategies, positions, and objectives encouraged by the institutional critique are tried and tested. The denial of populism is one of the ideas and one of the innovative positions. Instead, experts from different disciplines, organizations, including cultural organizations, call to think about the audience as a heterogeneous entity, its activities focusing not on a wide but as different audience as possible. It was concluded by the sociologist Paul DiMaggio already in 1986 when writing that "only lately the leaders of institutions have begun to seek an audience of social diversity, not so much for profit" [3]. In turn, the cultural theorist Nina Mentmane is absolutely convinced that "it is not the number of visitors but their diversity that is important" [4].

The most common concern for "diversity" is placed under the responsibility of the management of organizations, by it understanding different types of information but the nature of the event itself and the point of reference of the main qualitative indicators, namely, pursuing the increase in the number of visitors, remain the same. This is also determined by the previous tradition (informal rules), from which the contemporary art organizations cannot refuse so quickly. Nina Mentmane calls for being careful of the quest for a greater public attraction as it makes one choose the average denominator, and, thus, to often lower quality of the project. Instead, the diversity of the implemented events is more significant than the increase in the number of visitors.

\section{The establishment of the studio "Lokomotive" and cultural and information center " $K @ 2$ "}

In the 90s, the new media also became an important material for activists working in the film sector since with the collapse of the great film industry, several small film studios were established, ("Devinii”, “Kaupo", “Juris Podnieks Studio"), including "Lokomotīve" (1995) where Roberts Vinovskis, Carl Bjorshmark worked, but from 1997 - Kristīne Briede as well. 


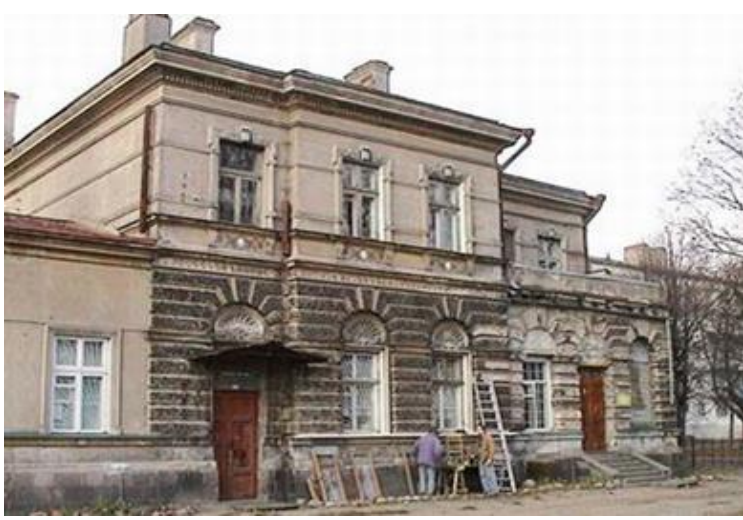

Fig. 1. K@2 first building in Katedrales street 2 (courtyard facade) [Source: from K2 personal archive]

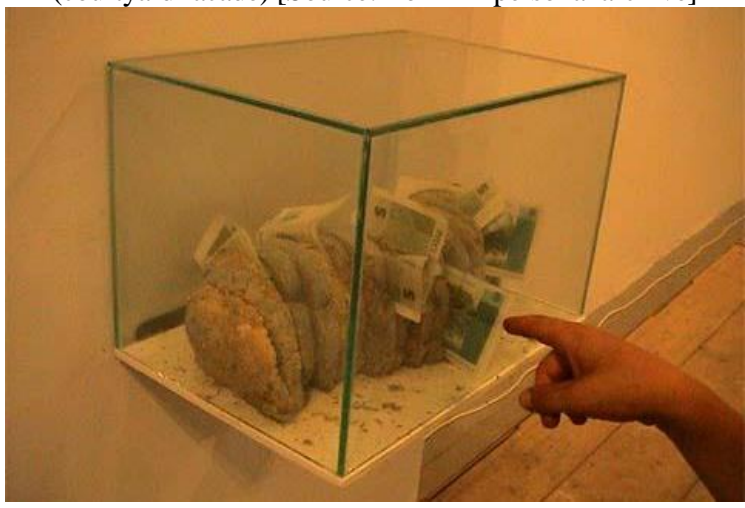

Fig. 2. Work from group exhibition "Korupcija" in Art gallery K. Māksla, 2002 [Source: from K2 personal archive]

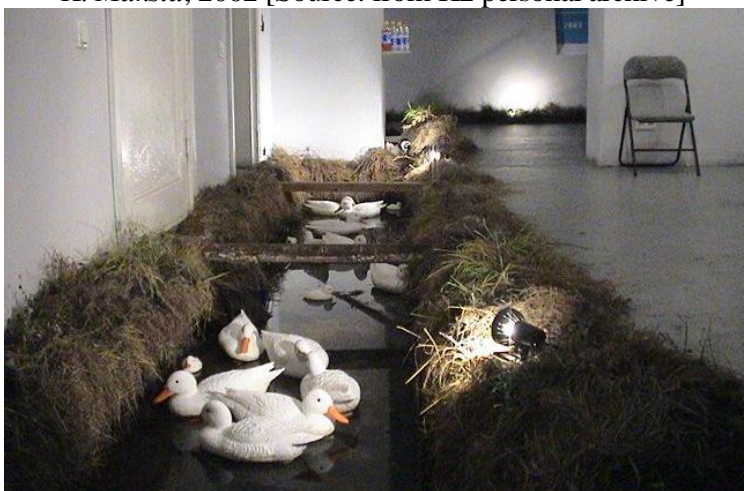

Fig. 3. "Pīḷ dịkisis" from A.Bules exhibition "Kāpēc es?“, in Art gallery K. Māksla, 2003

[Source: from K2 personal archive]

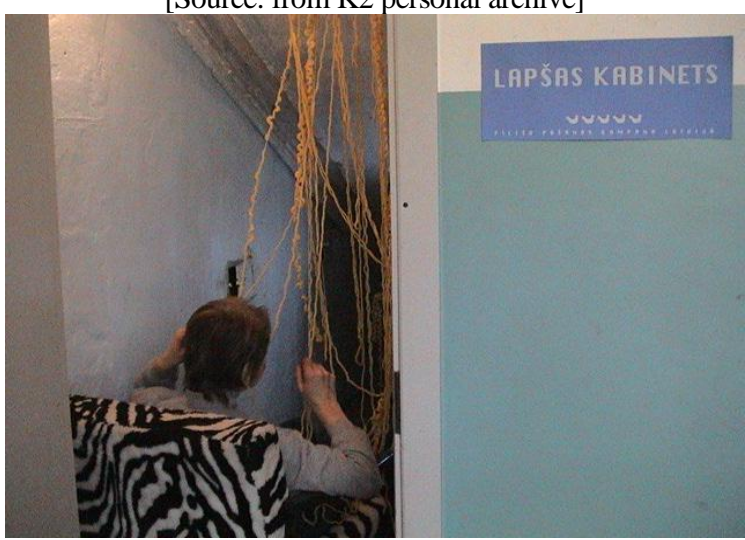

Fig. 4. "Lapšas istaba" from A.Bules exhibition "Kāpēc es?", in Art gallery K. Māksla, 2003

[Source: from K2 personal archive]
In 1997, creating a cycle of documentary films on Latvian border towns, the directors of the documentary film "Borderland - footprints on the borders" - Kristine Briede and Carl Bjorshmark came to Karosta. In turn, in the summer of 2000 in Karosta, the project "Subjective/Objective" [5] lasted for three months, organized by Kristine Briede and the Swedish artist Tove Torbiornsson with the motto "Look at yourself through foreign, untamed eyes". Within this project, the local children and young people had the opportunity to participate in the Latvian and foreign cinema artists' workshops "Camera Obscura", "Environment and Sound", "Analog/ Digital" and others, including drawing, modeling, animation, and singing workshops. At the Officers' House, the children's summer camp "Fabric. Canvas. Screen" was organized, led by the students of the Stockholm Royal Academy of Arts. Children and young people took part with great enthusiasm in the workshops, therefore, with this project a tradition was established that artists who come to work in Karosta in residence, devote some of their time to classes with children.

The project ended with an exhibition which exhibited photographs, objects, video, and sound installations and which was then housed in a fivestory uninhabited building at Ģenerāḷa Baloža ielā 1 . One of its walls $\left(300 \mathrm{~m}^{2}\right)$ was coated with a screen fabric woven at the factory "Lauma" and stitched by the inhabitants of Karosta, on which films previously footaged at Karosta were projected through a number of antique projectors, where artists and people of Karosta expressed their views on the local reality. The exhibition was opened parallel to the ambitious event "Tranzit Zero", dedicated to the documentary films which was attended by film producers, directors, and other film-related professionals from all over the world.

For the project "Tranzit Zero", the creative group "Lokomotīve" won the Latvian Artists Union's 2000 "Year Award", recognizing it the most successful project in one of the regions of Latvia which was welcome as a successful example of the public art process within which it was managed to activate and involve the local community in collaborating on the project.

After the projects, implemented in August 2000, Kristine and Calle decided to stay at Karosta to further not only "use" the environment for their creative work but to "invest" the creative ideas back in it. The "Cultural and Information Center K@2" was created - the cultural infrastructure which actively cooperated with other similar centers and creative personalities in Latvia and abroad. The situation is reflected by the fact that not even once in the next years of the existence of "K@2", various satellite events were held there within the framework 
of the projects, organized by the RIXC Center for New Media Culture, the events organized by the Arts Office "Open" (the workshop "Communes after Communism" in 2004, within the framework of the interdisciplinary, international arts, and culture project "re_public art) of the " Latvian Center for Contemporary Art", exhibitions, cinema lessons, and other developments, the initiative of which came from the independent institutions. The lure of the peculiar environment of Karosta (not to say exotic) and relatively cheap costs contributed to it.

The public organization "Cultural and Information Center K2" was officially established on December 07, 2000, by 17 private persons united in a common accord. The organization's objectives were defined "to create the center for culture, education, information, and cooperation, for the existing situation to create alternative conditions at Karosta, to transform the center into a place of international importance for the exchange of culture and information to promote a comprehensive development of Karosta" [6]. Later, on May 24, 2005 , due to changes in legislation, it was required to reregister the public organization as a union. In this document, the objectives of "K@2" already from a local instance are rerouted to global one as one of the objectives of the future "to encourage a comprehensive development of the city of Liepāja, the Republic of Latvia, and other European countries" [7]. It was also noticed and positively assessed by the local press. Trying to dispel the stereotypical perception of Karosta as a "malignant boil" on Liepāja, at that time, the journalist Indra Imbovica writing about the cultural life in Liepāja concludes, "In this desolate region seemingly left by all the good spirits, neither the good intentions of bosses nor money but two "crazy" freelancer artists, so to say, aliens from the sidelines, came, saw, and set to motion this "inert", "apathic wheel", the alien matter of Liepāja called Karosta" [8].

As the objective of their operation, the leaders of the Cultural and Information Center "K@2" considered the creation of an alternative environment to the existing one," We are not trying to impose anything on anyone, but to offer, to show that there is another alternative that it is possible that one may think differently. Currently, we offer information to citizens of Karosta what here comes in a natural way, during the visit of people from different parts of the world. This way we strive to present some options" [9]. A question always remains open how willing the inhabitants of Karosta and the city of Liepāja are to accept this choice themselves.

In an interview shortly after the founding of the center, Kritīne Briede said, "Our original objective was to create life in these ruins with the aid of culture. But soon we realized that this environment in terms of the social responsibility is not yet ready. Examples include the fact that we are constantly robbed. This is the main reason why up to this moment "K@2" has not become such as we have wanted it to be created. It would be good if young people come with their own initiatives. I hope we'll succeed in getting people of Karosta involved and become a socially active part of the society" [10].

Also, we were faced with the fact that the continued unequal movement of information related to the developments in culture, in the periphery (this is not only about Karosta) created a large gap in the understanding of the contemporary art, even in several generations. If since the Art Days 1984, the citizens of Riga are gradually being "domesticated" to the contemporary art, then in the periphery this "domestication" has to be started from the initial positions in a number of places, doing so not because it would be vitally necessary for the survival but to get to know the cultural diversity. Kristīne also admitted that "a large part of those things that we do are unusual in this environment. Therefore, we have "to raise" our own audience, a different generation. The audience which is now in Andrejsala is "raised" within twenty years, thanks to "Kinogalerija" and the Cinema Festival "Arsenāls". So far, nothing of the like has happened in Liepāja. Hence, the contemporary culture is alien to the general public" [11].

\section{3. “K@2" open space - the secular art gallery "K. Māksla?"}

In the context of the new institutionalism, the space or the "open space" concept gets more and more important. Space limits become more labile, harder to fix, and defined. Trying not to accept the consumer society's rules of the game, since the $90 \mathrm{~s}$, the contemporary art institutions sought a way out in the new concept of the public space which offered a democratic space for the diversity of the creative activity, contributed to the application of different models of collaboration to allow experimenting with interactions between different disciplines, stimulate teamwork, and try to involve viewers in their activities. The space of the creative expression within the new institutionalism should not be understood to include the local or a narrow spatial sense. Quite often, electronic resources (the Internet), printed matter, audio, and video recordings, and other media less frequently used in the sphere of art become the space for the creative expression and communication which have now become an integral part of the cultural institutions. Within the framework of the new institutionalism, "space" becomes a communication environment, regardless what physical or virtual substance it takes. 


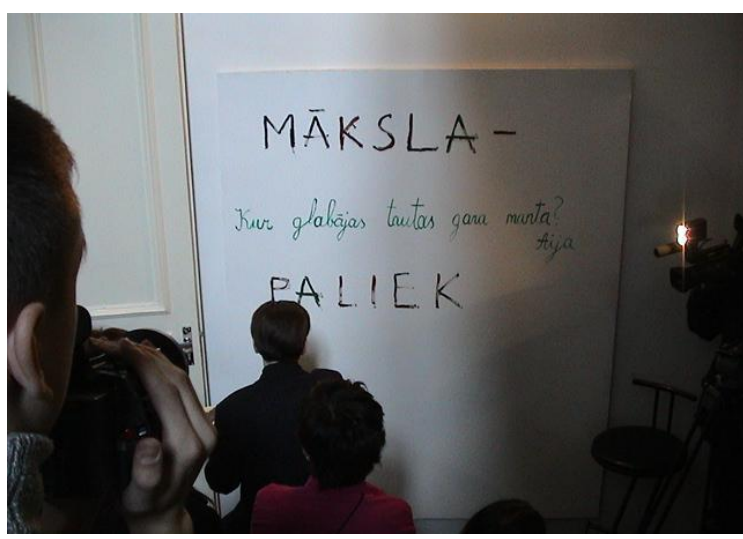

Fig. 5. Aijas Zarinas and Einara Repšes opening exhibition, in Art gallery "K. Māksla?", 2004 [Source: from K2 personal archive]

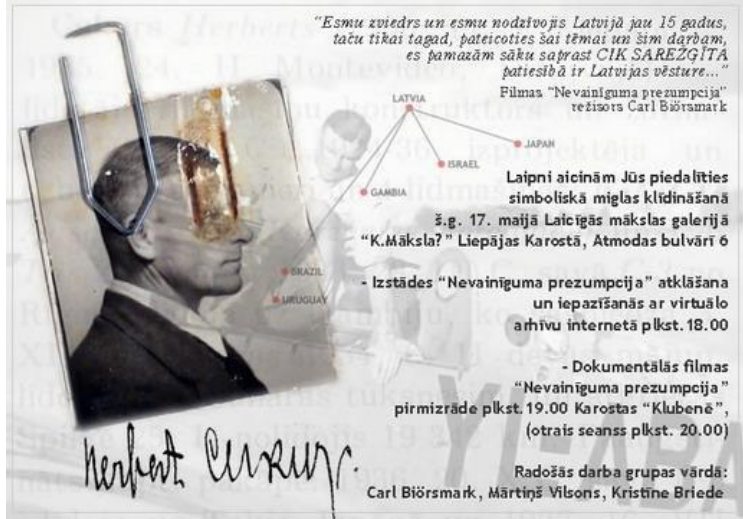

Fig. 6. Exhibition "Nevainīguma prezumpcija" postcard, in Art gallery "K. Māksla?”, 2005 [Source: from K2 personal archive]

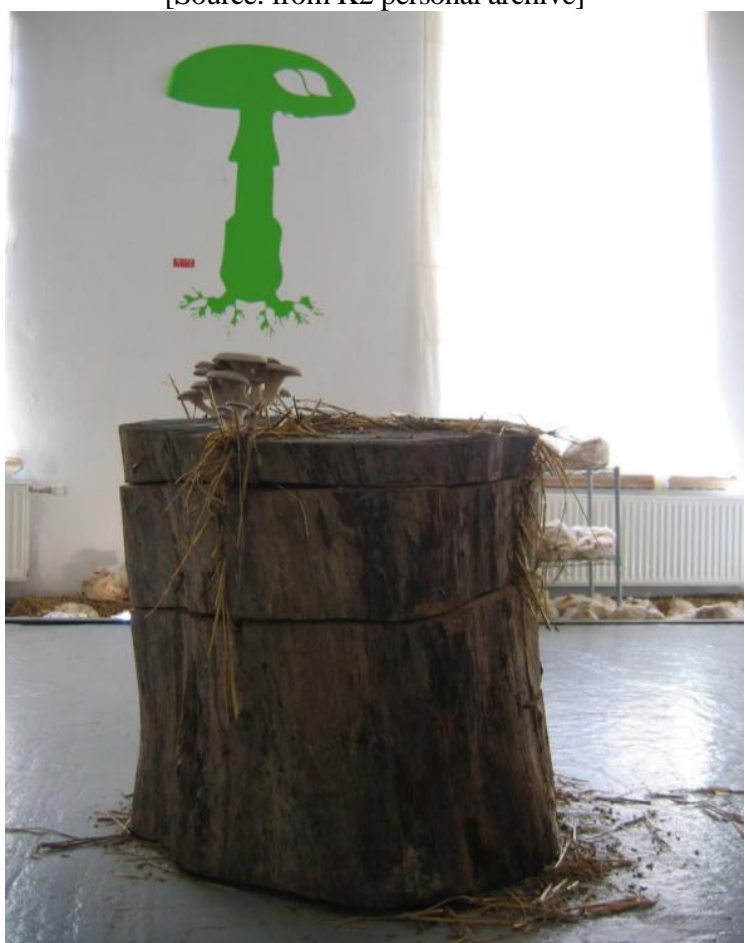

Fig. 7. Mushrooms growing process in project "LabiChampi" in Art gallery "K. Māksla?”, 2007

[Source: from K2 personal archive]
Hence, for a long time, the art institution is not only a place to exhibit or store works of art. It is an active part of the creative process [12]. With such beliefs, "K@2" was created and worked. In the practice of the Cultural and Information Center "K@2", all of the above aspects of space were essential. It is evidenced by the referenced below structures of the organization which have not arisen as a result of a long or targeted planning but arisen spontaneously, following the need encouraged by the idea.

In total, it is possible to record eleven projects which at different times and with different intensity and duration were implemented within the framework of "K@2": the creative children's room, the Latvian language courses (Katedrāles iela 2, since 2001), the secular art gallery "K. Māksla?" (Atmodas bulvāris 6, from 2001), and the adjacent to it "Skatītava - Lasītava" (since 2004, a publicly available book and video storage place), "Dzejnieku naminsš" (Studentu rotas 3, since 2004, a meeting place of the new literaries), "Kinoosta" (Atmodas bulvāris 6a, since 2003, for the cinema and cinema lessons) and "Klubene" (Ģenerāḷa Dankera iela 1, from 2003, with theatrical, circus performances, etc., concerts, festivals, and festivities), the analytical culture edition "K. Kultūra" (since 2004),"Kandidātes zāle" (since 2005, a meeting room for potential deputies and people), artists' residences and workshops. With the time, "K@2" also began to domesticate the socalled "Gaismas māja" (Cēsu rotas ielā 2) (Fig. 10) which until then had consisted only of the external facade for several years - without a roof, ceiling, windows, etc.. It was meant to be an exhibition center which remained at the stage of a project.

From 2000, “K@2” regularly organized cultural projects of the national and international scale photo and video workshops ("Fotovirtuve", 2001), workshops ("Communes after Communism", 2004; "Photo Culture", 2005), exhibitions were held in the gallery ("Presumption of Innocence", 2004), a press edition was issued and publications were placed on the Internet.

In the gallery name, "secular" meant to timely, effectively, quickly respond to events while they were topical. As claimed by the authors of the idea of the gallery, they were not so much interested in contemporary as in temporary, transient processes and their reflection, [13] in addition, still with a question mark, asking whether what was being exposed in the gallery was really art.

The gallery became a public stage from which it was possible to speak through the language of art. It hadn't a strict time limit of holding the exhibitions or plans drawn up several years before. These open, 
flexible limits allowed to talk about topical, often allowing to implement a spontaneous but a crucial idea. Therefore, the curators of the gallery paid attention not to art as a complete result but emphasized the importance of art as a process. Therefore, "secular" exhibitions were held there almost all the time, one replacing the other, often bringing together people of different ethnic origin and of various social layers. The whole time of existence of the gallery, it was open every day from 14:00 till 19:00. It became the first house in Karosta where the first-floor windows were without bars.

In a total of 6 years, around 65 exhibitions were arranged. Most often they were expositions where their creative experiments allowed themselves to sign up more than one new artist, art school, and university students, curators, researchers, etc.. Mushrooms were grown in the gallery ("Good Champi", 2007), visitors were confused by the graffiti artists' ("Wan Dog is dead, 2006) and documentary photos of the Fridrihshof Commune ("Commune after Communism", 2005). The LAA sculptors have repeatedly exhibited their works here ("Čuguns Jāṇi" in 2004 and 2005), also painters ("U25”, 2007) and photo plein-air ("ZZZ", 2007) participants, LAA Department of Painting and Graphics alumni - the new artists (Laura Šulca, Kārlis Vītols, Anda Lāce, Laura Feldberga, etc.), artists who only with the time have got national and international assessment in the field of the visual art (sound artist JVLAM Master Degree graduate Voldemārs Johansons, LAA Design Department Master Degree graduate Kristaps Grundšteins) and naivists (Modris Sapuns, Olga Doreska, etc.), sound artists (Derek Holcer and Sara Kolster (NL) "bzzzzzzzzz (0aaa0090z988z0zz100100* (x) * (8901111010110' 2003), etc., evaluated the opportunity provided by this place to experiment. Many new curators have signed up for their first parkstics "school" here, starting to understand and try different strategies in organizing exhibitions (from the new media to the naive art, from painting to installation) and gained the skills of teamwork in the gallery. Each time, the gallery space was adjusted to the needs of the exhibitions - they were repeatedly recolored, glued with the wallpaper, water canals were fitted in them, heavy glass aquariums were hooked, sand, sawdust - heaped and bricks were placed on the floor, etc. - and much more that not everywhere could be dared to do.

Another finding of the gallery was the fact that it was open every day and enthusiasm-full guides regularly stayed there. From the first day of work, in the gallery worked the gallerist Ludmila Antonenko, who by then, along with the activist of Karaosta Brigita Maksimova was one of the most energetic picketers of the city.
In addition, thanks to the location of the gallery, every day it was visited by the local children after school who gradually "absorbed" art there, starting in the way of having warm tea.

The secular art gallery "K. Māksla?" was opened on September 01, 2002, with a group exhibition "Corruption" (Fig. 2) (Kristīne Briede, Agnese Bule, etc., in total, 16 authors, including citizens of Karosta and foreign visiting artists). The exhibition was arranged in the context of the Saeima pre-election scene.

The first exhibition was soon followed by the other two parts of the trilogy "Eldorado" and "Conscience" (curators Kristīne Briede and Carl Bjorshmark) that, when assessing the targeted messianism of 'K@2" at Liepāja Karosta, in 2002, became the Latvian Artists' Union of the Year Award winners, as a professionally compellingly addressed project in one of the municipalities of Latvia.

The ironical exhibition "Eldorado" was supplemented by milk rivers and the shores of kisiele made by the cook Inta Leimante working in the cafe "K@2". Among other objects, it exposed porridge gates and a fir-tree with voblas "Voblin". But with the pseudonym Timmy Snip, the artist Kristaps Gelzis took part in the exhibition.

In the exhibition "Conscience", jointly arranged by the creative team of the "K@2", a number of installations were exposed. One of them consisted of the composition of Maksims Borisovs (String, also Max), a young man from Karosta - an improvisation with manipulated objects and x-rays by Carls Bjorshmark "Hello, oldy!" and "Farewell, the new one!". The second installation included improvised noise "machines" and the Soviet-time synthesizers. At its creation, in the collaboration worked Aleksejs Emsis, Aleksandrs Ganza, and Romāns (Well No. 11), young men from Karosta but Maksis helped with the keyboard instruments and with vocals and noise Handjah. The works were implemented in collaboration with the video artist Sara Kolster (NL) and the sound artist Derek Holcer (USA, NL). In this exhibition, Sara Kolster exposed a photo series of Šķēde Dunes but the sculptor Kārlis Alainis - an unexploded shell which he found on the beach in Karosta and placed in a fixture cage, by this addressing conscience of the organizers of the exhibition who put in danger visitors of the exhibition.

As one of the most brilliant of the projects of 2003 can be mentioned the personal exhibition trilogy of the artist Agnese Bule "Kāpēc ES?". The first of them was "The Latvians before?". The exhibition was deliberately held before taking 


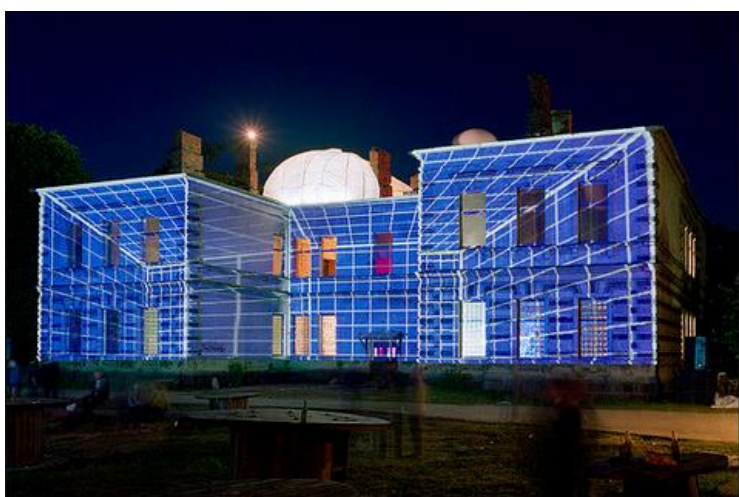

Fig. 8. Projection to "Gaismas mājas" in project

"LabiChampi" ietvaros, in Art gallery "K. Māksla?”, 2007 [Source: from K2 personal archive]

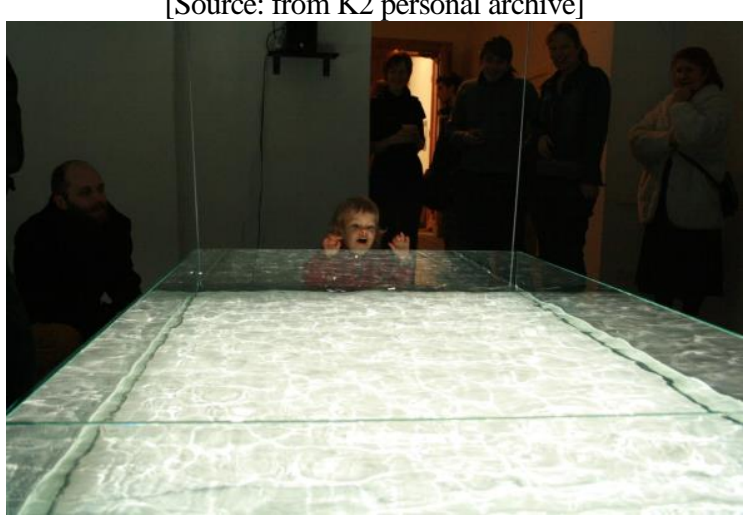

Fig. 9. Voldemāra Johansona exhibition "Gaisa straumes. Aero Torrent” in Art gallery "K. Māksla?", 2007 [Source: from K2 personal archive]

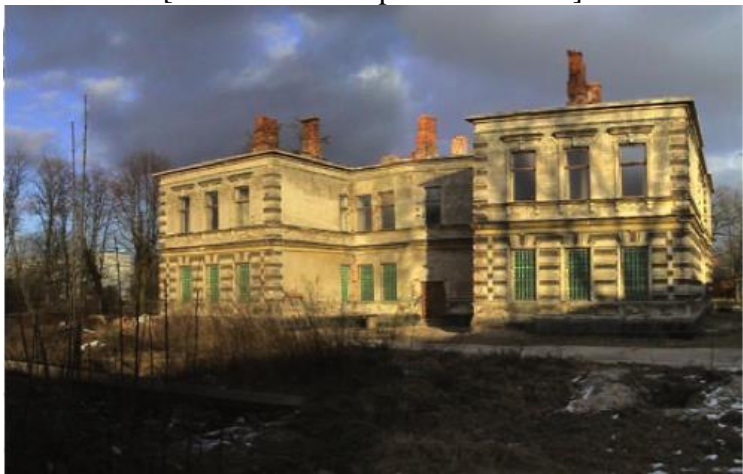

Fig. 10. "Gaismas māja" in Cēsu Rotas street 2 [Source: from K2 personal archive]

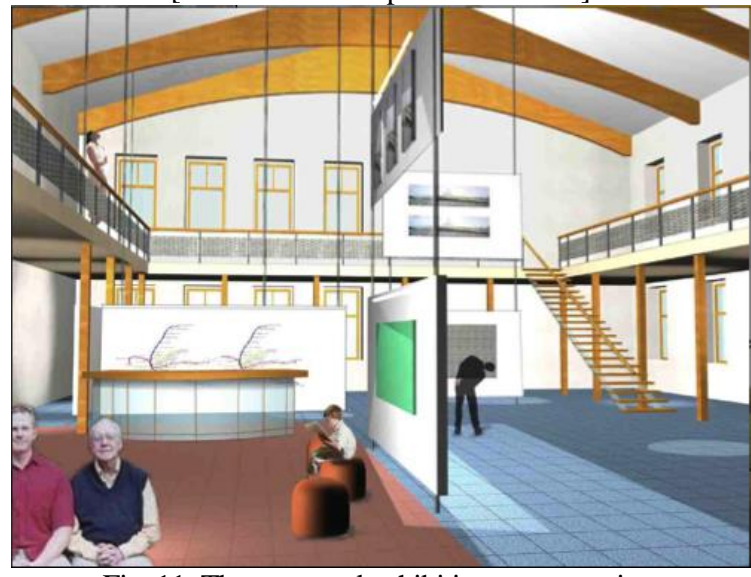

Fig. 11. The proposed exhibition centre project in Čēsu Rotas street 2 [Source: from K2 personal archive] the decision on September 20, 2003, when the citizens of Latvia participated in the referendum on Latvia's EU membership. The exhibition compiled and ironically interpreted the artist's research and knowledge about the Latvian vision of the world, the Latvian posture, and the special place of Latvians in the world space. A. Bule had accumulated these insights in the previous ten years. It was followed by the exhibition "Latvians blow little ducks" about the campaign of codswallop (Fig. 3) and "Kāpēc ES" with the pasta room" (Fig. 4), etc., fine irony permeated works. For the exhibitions, Agnese Bule was nominated for the Annual Awards of the Latvian Hunters' Association nominations for "A significant personal exhibition in one of the galleries of Latvia in 2003". But Kristīne Briede, Calle Biorsmark, Agnese Bule, the gallery "K.Māksla?" - for the project "Kāpēc ES?", and the exhibition "Latvians blowing little ducks" got a nomination as a professionally convincing addressed project in one of the municipalities of Latvia.

In 2004, the widest publicity for the media buzz garnered in the gallery and in "Skatītava - Lasītava" exposed a double exhibition of the painter Aija Zarina and already the former Prime Minister Einars Repše (curator A. Druvaskalne-Urdze). The central painting of the exposition of Aija Zaringa "Conversations on Art" was a painting with the crucified ex-minister but Einars Repše in his first public exhibition "Unfinished Studies" exposed nudes, landscapes, and still-life painted under the guidance of N. Naumovs (LAA). Originally, the double exhibition was intended as a communication but the result was a confrontation. But one of the climax moments of the opening became the question asked by A. Zarina "Where does the national sentiment is kept?" and the proof of E. Repše "Art remains in memories" (Fig. 5).

In the same year, Karosta Gallery was the first that ten years after the death of Jānis Viṇķelis exposed the collection of the great artist "Guards and Riflemen". Once, the Liepāja Museum had refused to do so. Assessing the originality of the artist in the context of art in Latvia, which also was underlined by the monograph issued by the art scientist Inga Šteimane, after the exhibition, a large part of the collection was stored at the Latvian Museum of Contemporary Art. After the exhibition of paintings of Jānis Vinķelis, the exhibition "Salon" was held by the Karosta photographer Vasilijs Borjajevs in the same gallery which documented the people of their time at Karosta but a short time later, in the gallery the photographer's works of the late sixties were also exposed there, depicting a great social and anthropological material on the daily life of the marine city. 
Watching how with Latvia's accession to the European Union, it arrived at Karaosta, in 2005, the project "Eurowatchers" was developed as Kristīne Briede's, "RIXC", "K@2" Media Lab, Karosta's children, their parents, and visiting artists joint venture - "European celebration". The idea of the project and the name arose as an analogy with birdwatchers who observe birds, sitting lying in wait, and as a fixation of observations creates popular science stories. Artists, journalists, and tourists, etc., going to watch, fixate, and get to know the new Europe, were counter-watched, counterinterviewed, and documented by the local Eurowatchers on the go.

Not always, the secular should be a loud and topical event at the moment. It can also involve lingering issues not addressed as necessary as in the case with the documentary exhibition "Presumption of Innocence" (Fig. 6). For the first time, with the help of documents and the film, the exhibition allowed a wider audience to get to know Herberts Cukurs, the first aviator of the Latvian free state and later for the crime of genocide accused and murdered in South America. Calle and Kristīne, collecting and studying the materials, went to Brazil to study what until then was kept in the archives of the aviator's family and in Latvia was not known. As a result, the exposition does not accuse, not vindicate, it only shows that there are too many unanswered facts to declare any guilty as the "Presumption of Innocence" provides that a person is not considered to be guilty if the court has not recognized him as such. These facts, the filmed interviews, copies of documents, and letters were passed to the Public Prosecutor's Office for further investigation but so far the case has also remained unfinished.

The gallery also had an important role in the creative work of artists for whom it often became the first public communication with the viewer. For instance, the personal exhibition "Zhuangzi and Butterfly" (2004, curator Aija Druvaskalne - Urdze) of the philosopher and cultural historian, naivist Olga Dorenska was noticed at the exhibition of 2003 "Autumn. Private Space" (curator Ieva Kalnina).

But in March 2007, introducing the main event of the year - the International Festival of Mushrooms "LabiChampi" (June 01-03), at the gallery, the artist and architect group "EXYZ" exposed bags with mycelium and began to grow mushrooms (Fig. 7). This process could be watched on the Internet with a network camera. By the time, the exposition transformed and changed - grew. The idea of the fungi dates back to 2005 when, despite the freezing temperatures in February, the architect Nicolas (Nicolas Henninger, FR) arrived at Karosta and observed a peculiar natural phenomenon here a road highlighted by the heating main in the snow- capped landscape. In order not to lose this valuable energy, he got an idea that by building small greenhouses above the heating mains, the locals could grow mushrooms in them and pick them, which is also less common but a matter-ofcourse cultural tradition for us. Once, JSC "Liepājas Siltums" had not given such permission but the germ of the idea had already been delivered. Next, it transformed into the study of mushroom cultivation, offering the uninhabited houses at Karosta to adapt to the urban mushroom cultivation in the ambitious "Mushroom Roof" above "Light House" and at the "Mushroom Festival" (Fig. 8).

In December 2007, the artist Voldemārs Johansons just returned from studying at the Institute of Sonology of the Hague - at that time a rising talent who made his latest work at the gallery - the aesthetically refined but technically and researchintensive - "Air Currents. Aero Torrent" (Fig. 9) (which was announced a nominee for 2009 Swedbank Art Award). At the turn of 2008/09, Voldemārs Johansons was the last artist who with the work "Rainbow" closed the activities of the gallery.

Whether it is an exhibition of traditionally exposed paintings or caring for the growing culture, "screaming" (the exhibition of Aija Zarina "Conversations on Art" and the exhibition of Einars Repše "Unfinished Studies"), or on the contrary contemplative, interpreting of the environment of Karosta (Laura Feldberga "Inner Vision"), almost every exhibition of the secular art gallery "K. Māksla?" reflected its unified concept, manifested in a variety of artistic representations.

\section{Epilog}

One of the last, largest, and most ambitious projects of "K@2" was to create "Campus Karosta" ("Karosta - Culture Port", 2008) - an art education center, opposite the military center (Fig. 11). It also raises the idea of creating the academic educational program "New Media Art" in the Liepāja University (until 2007-Liepāja Academy of Pedagogy) which grew on the material, technical, and human resources of "K@2". The philosophy and all of the structure of the new education program was also based on the checked for years' independent cultural initiatives [14] and the used cooperation and flexibility policy.

Without the mentioned program, "K@2" experience directly and indirectly served as inspiration for the future cultural and political activities. Only after liquidation of "K@2", the Association of NGOs in the field of the contemporary culture (founded in 2009) was founded, launching a concern for the rights of nongovernmental cultural organizations, taking the 
rights to representation. Only later, the National Library of Latvia launches the project "Trešais tēva dēls" (from 2006), providing the high-speed wireless Internet in the regional libraries. Only since the end of the first decade of the $21^{\text {st }}$ century, we can talk about gentrification as an economically sound and politically patronaged strategy which after several decades of proven practices is also introduced in Latvia for "rehumanization" of economically and socially declining post-industrial areas ("Andrejsala", "Spīḳeri”, "Tabakas fabrika", etc.) and the term"creative industries" becomes a national priority. There are more and more such examples. Many activities and insights recognized as good today have come directly from the non-governmental sector in which they are glimpsed and highlighted but only later validated by the State institutions and clothed in forms understood by the consumer culture.

\section{References}

1. Möntmann, N. Curating with Institutional Vision. The roundtable discussion between Roger M Buergel, Anselm Franke, Maria Lind and Nina Möntmann. In: Art and its Institutions. Current Conflicts, Critique, and Collaborations. Möntmann, N. (ed.) London: Black Dog Publishing, 2006, p. 38.

2. The reconstruction of the first building of the organization at Katedrāles ielā 2 was made possible, thanks to the support provided by the United Foundation of the Netherlands (LVL 36 000). By the support of the Daniel Langlois Foundation and the Embassy of Canada, the Media Laboratory, the so-called "digital kitchen" was equipped. During further operation, the organization has attracted funding with various projects from the European Cultural Foundation, the Soros Foundation for Contemporary Art, the State Culture Capital Foundation (SCCF) and the Culture Department of Liepāja City Council, the European Social Fund, and other projects' competitions.

3. DiMaggio, P. J. Introduction. In: Non-Profit Enterprise in the Arts: Studies in Mission and Constraint. DiMaggio P.J. (ed.). New York: Oxford University Press, 1986, p. 7.

4. Möntmann, N. Art and its Institutions. In: Art and its Institutions. Current Conflicts, Critique, and Collaborations. Möntmann, Nina. (ed.). London: Black Dog Publishing, 2006, p. 11.

5. The participants of the project were the Swedish artists Filipa Arrias, Jesper Nordal, Javier Garsia and the Latvian artists Ivars Grāvlejs, Andrejs Grants with his students, Elizabete Melbārde, Mārcis Bendiks, Andrejs Ivanovs, Vasilijs Borjajevs, Viesturs Graždanovičs and others.

6. The Articles of Association of the public organization Cultural and Information Center K2. Approved in November, 2000. Registered on December 07, 2000. The founding general meeting was attended by: Kristīne Briede, Santa Simsone, Gaiga Korņilko, Gunārs Kazask, Iveta Ansone, Lāsma Eversone, Agnese Mackēviča, Aija Saldovere, Aiga Braša, Carl Bjorshmark, Ineta Statgale, Juris Āboliņš, Arturs Pērkons, Ārijs Orlovskis, Velga Jansone, Valdis Skujiņš̌, Jose Javier Manzur Garsia.

7. The Articles of Association of the society Cultural and Information Center K2. Approved on August 30, 2004. Registered on May 24, 2005.

8. Imbovica, I. Vai Karosta ir Liepājas svešķermenis? Kurzemes vārds, 2001 gada 8. februāris, 2. lpp.

9. Auziṇa, I. Balto plankumu meklētāji šaipus ekrānam. Studija, 2001, aprīlis/maijs, 24. lpp.

10. Imbrovica, I. Karostas ādere - tonusam, informācijai, radošajam garam un attīstībai. Kurzemes vārds, 2001. gada 21.februāris, 7. 1pp.

11. From the conversation with Kristīne Briede on April 26, 2007, at Karosta. Recording of the conversation is kept in the author's archive.

12. Möntmann, N. Curating with Institutional Vision. The round table discussion between Roger M Buergel, Anselm Franke, Maria Lind and Nina Möntmann. In: Art and its Institutions. Current Conflicts, Critique, and Collaborations. Möntmann, N. (ed.) London: Black Dog Publishing, 2006, p. 50.

13. Mazika, S. Laicīgi - tas nozīmē savlaicīgi. Kultūras Forums. 2004, 28.maijs/4.jūnijs, 8. lpp

14. The academic program "New Media Art" was developed on the basis of the three-tier cooperation between the Liepāja University, Cultural and Information Center "K@2" and the RIXC Center for New Media Culture. Additionally, a significant support in the development and initiation was also rendered by the City Council of Liepāja.

INFORMATION ABOUT THE AUTHOR:

Santa Valivahina (Mazika) (1979) Mg. art (LMA, 2007) is an art scholar, critic, and curator. She is working at the Art Research Laboratory of the Liepaja University and is writing her doctoral thesis at the Art Academy of Latvia about new forms of cultural institutions and their development in Latvia. She has published reviews about art events, she has also been a co-curator in the temporary art gallery "K. Māksla?" (2005-2009) Karosta, Liepaja, and elsewhere, a co-curator of the exhibition "Autumn 2006" in Riga, the Latvian Railway History Museum. E-mail: santa.mazika@liepu.lv

Kopsavilkums. Dibināts 2000. gadā kultūras un informācijas centrs “ $K @ 2$ ” bija viens no pirmajiem neatkarīgajiem kultūras centriem Latvijā, kurus pēc neatkarības atgūšanas 90. gadu otrajā pusē, meklējot alternatīvu izpausmes telpu, pamazām sāka dibināt jaunie mākslinieki. Neapzināti, bet likumsakarīgi š̄is parādības iekḷaujas jau kopš 20. gadsimta 70. gadiem sevi pieteikušā, bet Latvijas kultūrtelpai novatoriskajā "jaunā institucionālisma” kontekstā. 
Vairākus gadus te strādāja divi mākslinieki Karls Bjoršmarks un Kristīne Briede, pieaicinot savus kolēǵus gan no Latvijas gan ārvalstīm: veidot izstādes, vadīi kino lektorijus, īstenot radošās darbnīcas Karostas un Liepājas jauniešiem skaṇu mākslas, foto, video un citās jomās. "K@2" savā darbības laikā aizpildīja nišu starp māksliniekiem, iedzīvotājiem un politiķiem, kā arī darbojās jomās, kuras tajā laikā vēl pat nebija kḷuvušas aktuālas - brīvpieejas internets, grāmatu, video un audio ierakstu bibliotēka un lasītava, kā arī pašvaldības pārstāvniecība pilsētas "mikrorajonos", bezmaksas latviešu valodas kursi, spēlu istaba bērniem u.c.

Taču nemitīgie “izdzīvošanas apstākḷi” centram liedza ilgstošu pastāvēšanu, novedot pie slēgšanas 2008. gadā - brīdī, kad tika atzîta tā leǵitimitāte valstiskā līmenī. Taču Karostā izauklētās idejas turpina dz̄̄vot joprojām.

Raksta mērķis ir apskatīt dažas “K@2” aktivitātes un idejas Karostas sociālās attīstības kontekstā, kas saistītas ar centra darbību vizuālās mākslas jomā, kurā visilgāk darbojās laicīgās mākslas galerija “K. Māksla?". Paralēli tam tiks skarts jautājums par mākslas lomu reǵiona sociālās vides rehumanizācijā un alternatīvajām stratēǵijām, kuras tā piedāvā. Tādēḷ raksta ietvaros minētas atsevišķas galerijā notikušajās izstādes, kuras š̄is stratēgijas meklēja, taču, ņemot vērā materiāla apjomu, šajā virzienā pētîjums vēl jāturpina. 


\title{
Transformation of the silhouette of the urban space. Jelgava example
}

\author{
Aija Ziemel̦niece, Latvia University of Agriculture
}

\begin{abstract}
Through hundreds of years, the silhouette of Jelgava with church spires has changed several times. The culmination of the expression existed until World War II when the city was cruelly devastated and the restoration of the historic building was ignored. With the change of the political power, the city skyline changes alongside with it where the public understanding of the cultural values is readable. This statement is brightly confirmed by the comparison of the public attitude of the prewar and postwar time where the prewar political power is with a higher understanding of religious values and the role of churches in the society and the urban environment. In turn, the postwar policy stance during the $\mathbf{2 0}^{\text {th }}$ century brings in Latvia hatred towards cultural values. The urban construction space is a vivid example of the above mentioned. Thanks to the archive material it is possible to determine the progress of transformation processes of the historical urban environment.
\end{abstract}

Key words: silhouette, church spires, compositional solution, urban space, cultural and historical heritage

\section{Introduction}

In the race of the centuries, the skyline of the city of Jelgava is repeatedly admired in engravings (Fig. 1, 2, 3). It is possible to compare the historical building of the city and the modern building situation by studying archival materials.

The church towers of Jelgava are witnesses of the ethnically and confessionally varied composition of the townspeople, which formed in the times of the Duchy of Courland and the Tsarist Russian protectorate [8;2]. The palette of the ethnic composition featured in the architecture of the churches of each confession which, in turn, enriched the expression of the city's silhouette. The multicolor confessions Catholic, Lutheran, Reformer, Orthodox, and Jewish showed high economic development. According to the statistical data, in 1935, by their faith, people of Jelgava were distributed as follows: Ev. Lutherans - $77.1 \%$, Catholics $9.5 \%$, Orthodox $-4 \%$, Old Believers - $1.9 \%$, Moses believers - $6 \%$, the rest $-1.5 \%$ [1]. Not only the church spires were readable in the silhouette but also buildings of functionally different meaning - Town Hall, Fire Tower, residential buildings, Water Tower, the dome-shaped roof of the gas station. After the research of the archival materials and their systematization, the aim of the research is connected with the assessment of the silhouette of the historical and the modern Jelgava.

Several research assignments are defined for the assessment of the transformation processes of the urban construction space which are as follows:

- the assessment of the criteria of the structure of development of the historical urban space;
- the position of the historical churches in building of the river bank, their urban construction context in the assessment of the silhouette;

- the study of the visual shape of the silhouette in the contemporary situation.

The main method of research is based on the study of the historical archival materials and the comparison of the obtained results with the modern urban construction structure for the left bank of the river Driksa.

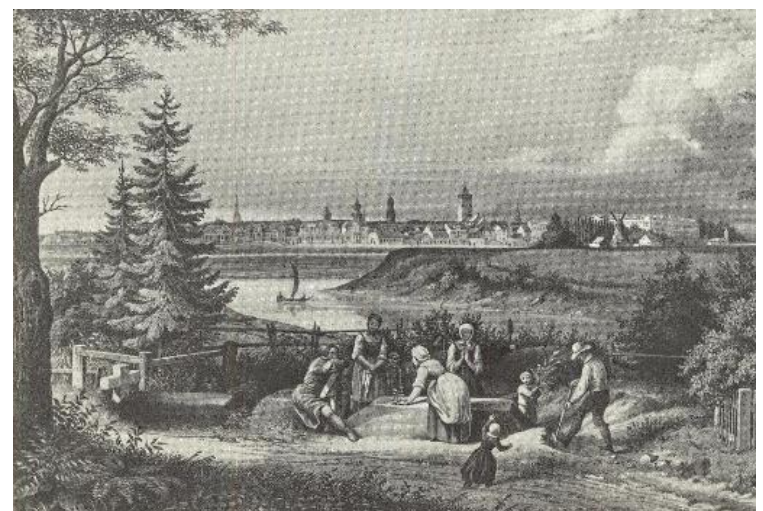

Fig. 1. The city skyline from Kalnakrogs Cemetery T. Miller's engraving (1852) [9]

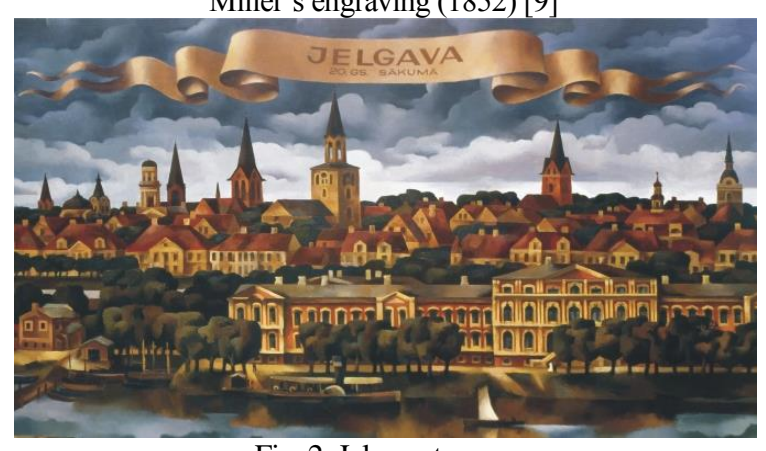

Fig. 2. Jelgava towers

[Source: M. Stumbris, oil, 2000] 


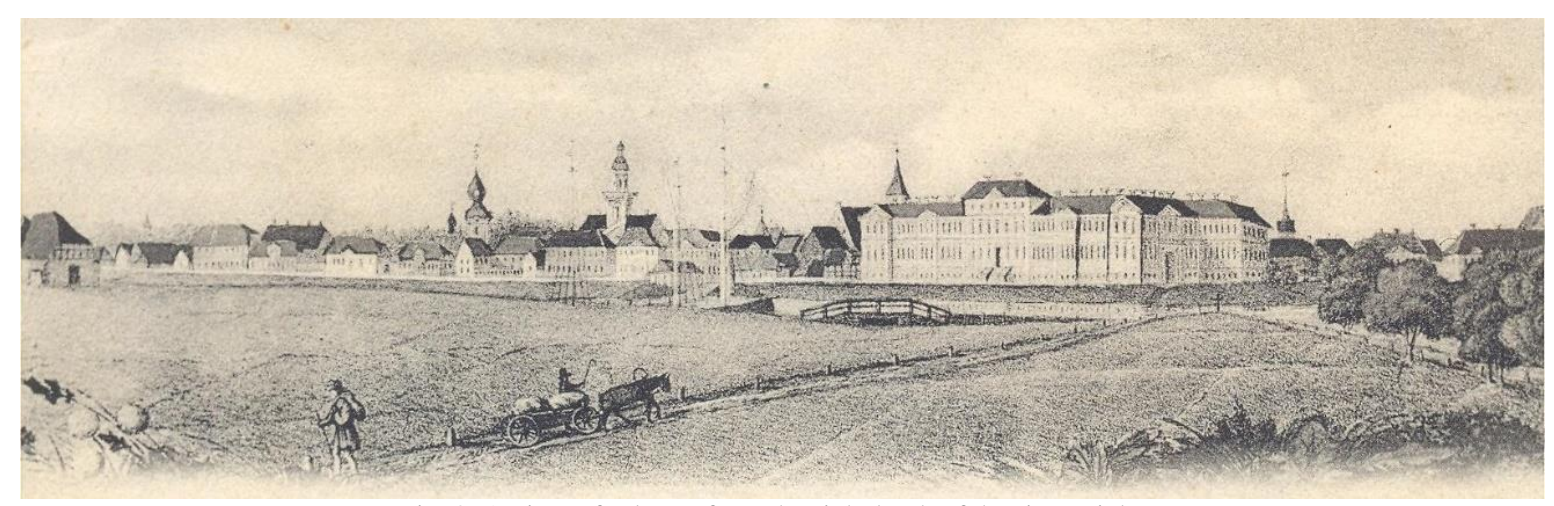

Fig. 3. A view of Jelgava from the right bank of the river Lielupe

[Source: the middle of the 18th century, JHAM]

\section{Materials and methods}

Both the historical map material of Jelgava and the ancient engravings show a peculiar silhouette of the city with many of church spires. With the development of the opportunities of the photographic image, the documentary material, especially brightly between the 20 s and 30 s of the $20^{\text {th }}$ century suggest of the expressiveness of the historic city skyline. Thanks to the documented material, it is possible to carry out the study of the urban construction space by individual zones of the church building.

The historical building of Jelgava has an expressed linearly stretched building along the left bank of the river Driksa where opposite the place of the seat of the Duchy, the grandest houses of the German aristocracy were located. In the historic urban environment, the embankment of the river Driksa was formed as the most elite place of the building location. Up to the $40 \mathrm{~s}$ of the $20^{\text {th }}$ century, in the study materials of the city skyline, several church spires are visible that are brought closer, as well as away from the river bank (Fig. 13).

The silhouette of Jelgava as the Duchy and later the capital of the times of the governorate has changed several times. The attractiveness of the city silhouette has already been admired in the $17^{\text {th }}$ century, in the engravings reflecting the ancient fortified castle of the Livonian times [5]. Through the construction of the new castle of the Duchy in the early $18^{\text {th }}$ century, several church spires and the character of the urban settlement are readable in the silhouette along the bank of the river Driksa. The same is true of the $19^{\text {th }}$ century T. Miller's engraving (Fig. 1). After the war, with the destruction of the city, the panorama of the bank of the river Driksa has drastically changed.

For the perception of the city skyline, the lines of sight are located on the driveway from Riga and from the viewpoints of Pilssala and Pasta sala. The length of the silhouette of the city's historical building along the river Driksa exceeded $1 \mathrm{~km}$ in the start of the $40 \mathrm{~s}$ of the $20^{\text {th }}$ century. The reference points of the length of the panorama line are the southern and northern edges of the old city ramparts and its canal, upstream and downstream the river Driksa. The city's ramparts exist until 1804, then they is dismantled. The distance between the ends of the ramparts is approximately $1 \mathrm{~km}$. Downstream the river Driksa or at the north end of the city the former Reformed or Calvinist church was located (1899) [8]. The church was built in a solid building line on Uzvaras street which formed a vertical dominant for the closing of Dobele street near Uzvaras street (Fig. 4). As a vertical accent, it concluded the city skyline in the northern part. The church had typical features of the Baroque style - thickly profiled ledges, ellipses, and windows of a semi-circular form, a Neo-Baroque tower spire [8].

Today, the historical location of the Reformed Church is marked by the old trees, circumferentially planted around the altar part of the church (Fig. 8). Close to the church's location, in the postwar years, a 4-storied school corps was built, bringing in the urban silhouette another scale and compositional point of gravity.

In the building on Uzvaras street, the position of the Reformed Church marked the road or the socalled place of the Northern Gate, leading out of town in the direction of the sea. In turn, in the southern direction, Uzvaras street was connected to the Market Square. It was decorated by 3 tower spires, so emphasizing the part of the city center.

As the first which was readable in the silhouette of the Reformed Church in the distance of $150 \mathrm{~m}$ was the Fire Tower (Fig. 5). The height of the tower was sufficient to view the city's rooftops. $80 \mathrm{~m}$ away from it, the Town Hall (1743) was located which was decorated by a spire (approximately $22 \mathrm{~m}$ ). Both the spire of the Fire Tower and the Town Hall tower were relatively lower than the Reformed Church. The highest spire of the Town Hall and the city was the German Ev. Lutheran Holy Trinity Church. It was located opposite the castle on the opposite bank of the river and with its impressive building volume symbolized the importance of the 


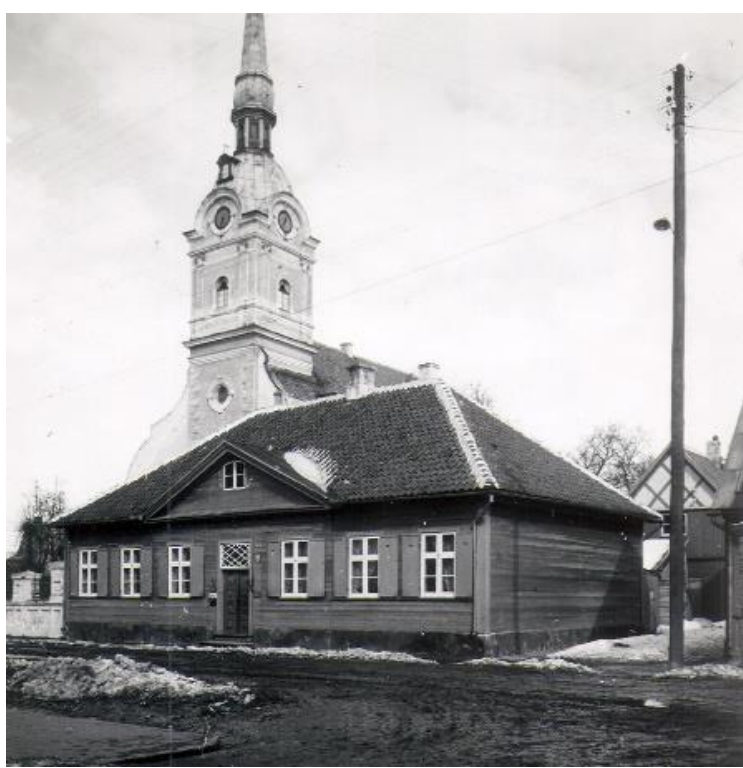

Fig. 4. The former Reformed Church on Uzvaras street [Source: JHAM]

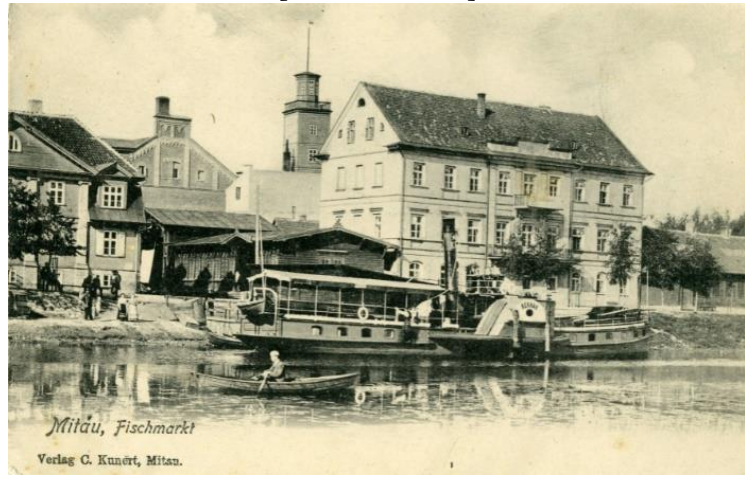

Fig. 5. The former Fire Tower was at the Market Square The early $20^{\text {th }}$ century [Source: JHAM]

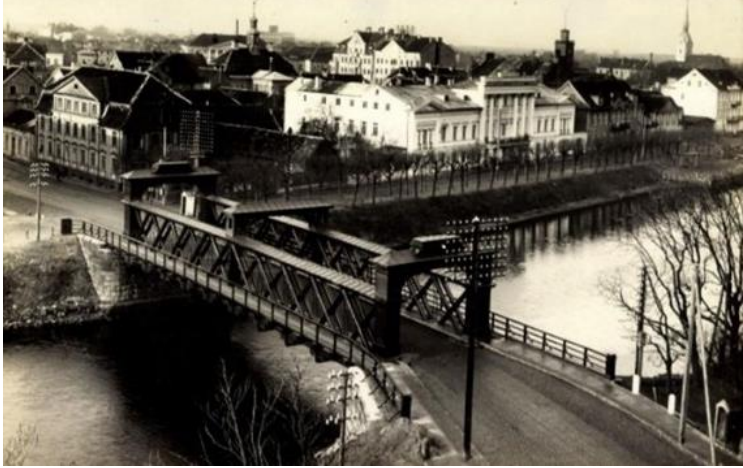

Fig. 6. A view to the Courland Chivalry House, Town Hall, Fire Tower and Reformed Church. The early 20th century [Source: JHAM]

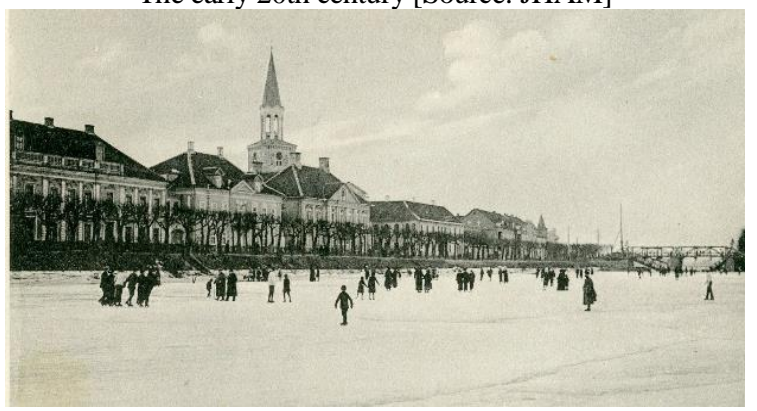

Fig. 7. A silhouette of the city with the tower Holy Trinity Church. The early $20^{\text {th }}$ century [Source: JHAM] capital city of the Duchy of Courland and the times of the governorate. The church was circumferentially surrounded by a 2 -storey building. The scale of the church spire compositionally strongly contained the structure of the urban construction space. This is attributable to the lines of sight which opened from Pilssala, Pasta sala, the Market Square or Akadēmijas street. The bell tower remaining after the war has obtained a provisional nature of roofing without a spire. Nowadays, the silhouette around the Holy Trinity Church is supplemented by a new bridge and a seamless 4-5 floor building line along the bank of the river Driksa (Fig. 9). In the lines of sight from the bridge over the river Driksa, upon entering the city, in the skyline until the 30 s of the $20^{\text {th }}$ century clearly dominated the massive facade of the Kurzeme Chivalry House that in individual viewpoints from the bridge of the river Driksa hid the spire of the Town Hall or the Fire Tower. During the times of the first free state, the Chivalry House representing the German power was dismantled and a 3-storey hotel was built in this place in the $30 \mathrm{~s}$ of the $20^{\text {th }}$ century. During the war, the city was burned down and after the war, in the place of the Town Hall and the Fire Tower, a high-rise residential building was built. The new building scale, density, and structure brought a different compositional character of the urban space in the silhouette. With disappearing of the tower spires around the former Market Square, the visual perception of the city's old place of the center has gone.

These four spires emphasized the historical part of the city center with a solid two-storey or threestorey building, which was decorated by pitched redtiled roofs around the Market Square. Both in the colorfulness and composition, the tower spires and the roof landscape left a lasting impression on the city's grandeur to the driver. The historic place of the bridge over the river Driksa has survived into the present, so it is easy to imagine the character of the old building. Nowadays, the street is widened and it has lines of tree plantations. When comparing the former Market Square with the installed green square instead, it can be seen that the form of the adjacent high- rise building, street, and square creates a new situation of the urban construction.

The southern part of the historical silhouette upstream the river Driksa was formed by a zone of church towers which started in the distance of $200 \mathrm{~m}$ from the Holy Trinity Church. Together, in the distance of 100-200 m, there was a synagogue, Academia Petrina, St. George's Church, St. Simeon's and St. Anne's Church, Nikolai Church (Fig. 10).

The last three ones are in the distance of $100-300 \mathrm{~m}$ from the bank of the river but their 


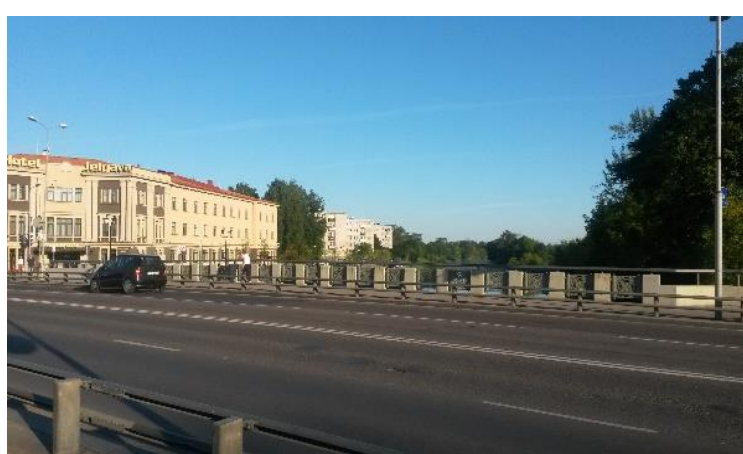

Fig. 8. Today, view to the Hotel [Source: photo by author, 2017]

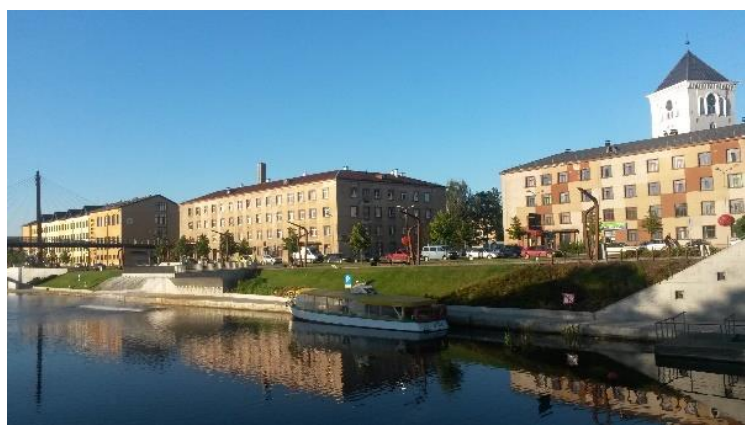

Fig. 9. Silhouette around the Holy Trinity Church [Source: photo by author, 2017]

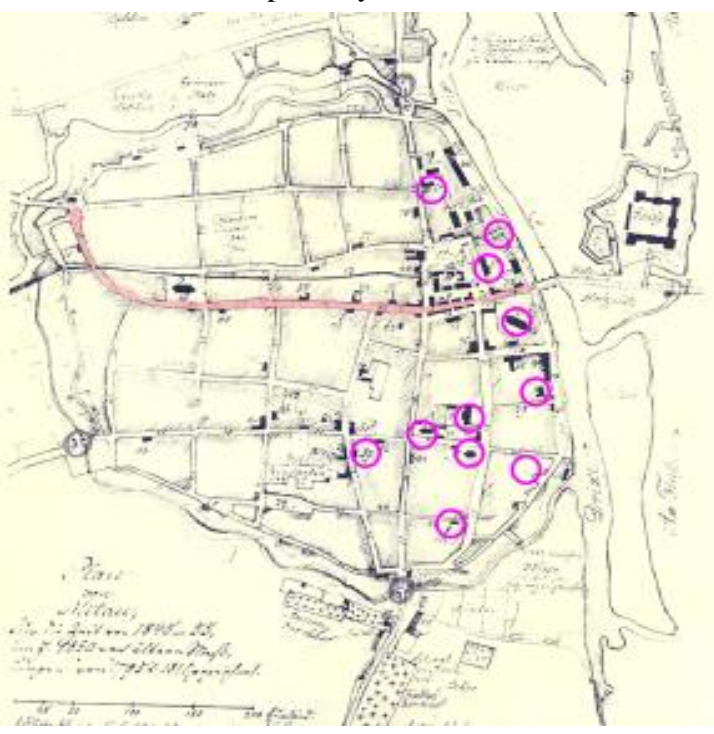

Fig. 10. Tower spires of the city's skyline along the left bank of the river Driksa.

The early $20^{\text {th }}$ century [Source: JHAM]

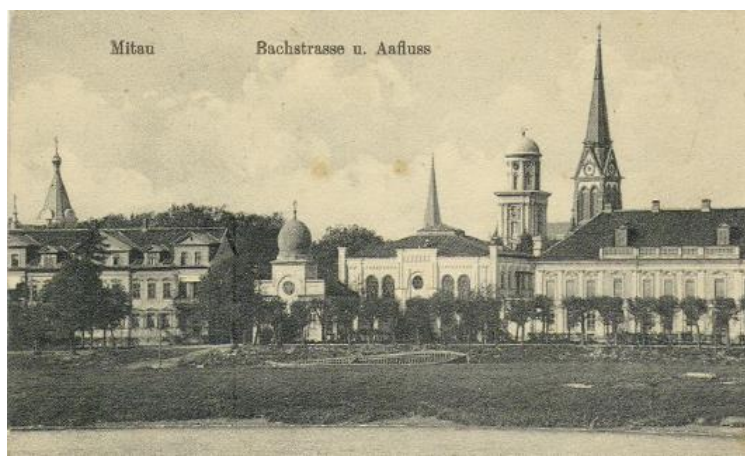

Fig. 11. Church spires silhouetted against the south. The early $20^{\text {th }}$ century [Source: JHAM]

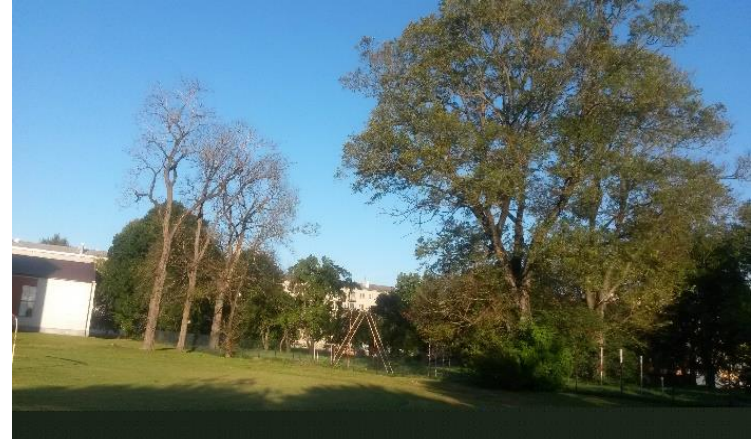

Fig. 12. Today, the historical location of the Reformed Church is marked by the old trees [Source: photo by author, 2017]

spires are prominent in the skyline. Of these mentioned above, the synagogue and the Nikolai Church have disappeared after the war. In this zone of the silhouette, the red-brick tower of the St. George's Church was the highest one that in the Neo-Gothic forms was rebuilt in 1906. Each of the the above spires formed a specific compositional character of the urban space. So, for instance, by ranging one tower after the other in the distance of $100 \mathrm{~m}$, in the silhouette, a spatial effect was formed by the synagogue, Academia Petrina, and St. George's Church. In turn, in the urban space, the St. Nicholas, St. John's and St. George's Church are located at the same distance $(300 \mathrm{~m})$, forming a triangle with equal sides in the plan (Fig. 11).

In the southern part, the silhouette line is concluded by the tower of the Nesterov House, St, John's Church, and the dome-shaped roof of the gas station. The St. John's Church marked the end place of the historic ramparts in the southern part. In the northern part of the silhouette, as mentioned above, the ramparts were concluded by the tower of the Reformed Church.

Today, Academia Petrina, St. George's Church, St. Simon's and St. Anne's Church, St. John's Church keep around themselves the green area or the garden.

Before the war, the Great Synagogue (1879, arch. J. Bārs) [8] marked a strong highlight of form creation in the silhouette of the city which was formed by a non-typical dome for the Latvian landscape instead of the tower spire (Fig. 15). In the postwar years, the historic building and its scale along the waterfront of the river Driksa from the Holy Trinity Church up to Uddens street has not been restored. Instead of the burned synagogue and the adjacent two-storey building, there is a seamless 5-storey building. On the opposite side of Ūdens street, instead of the disappeared 2-storey building, nowadays - a green area with a sports ground is located here. The penetration of the green zone in the silhouette of the historic building forms its shortening approximately on $80 \mathrm{~m}$. 


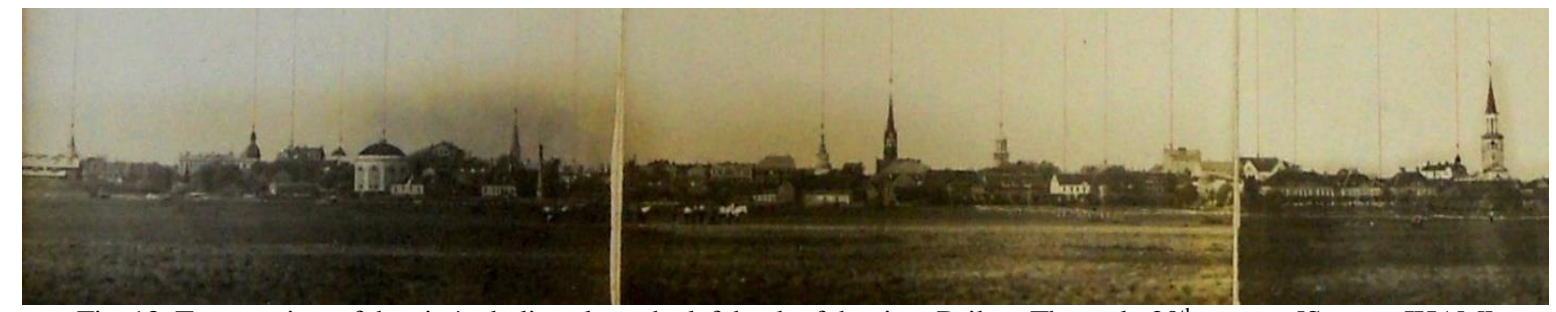

Fig. 13. Tower spires of the city's skyline along the left bank of the river Driksa. The early $20^{\text {th }}$ century [Source: JHAM]

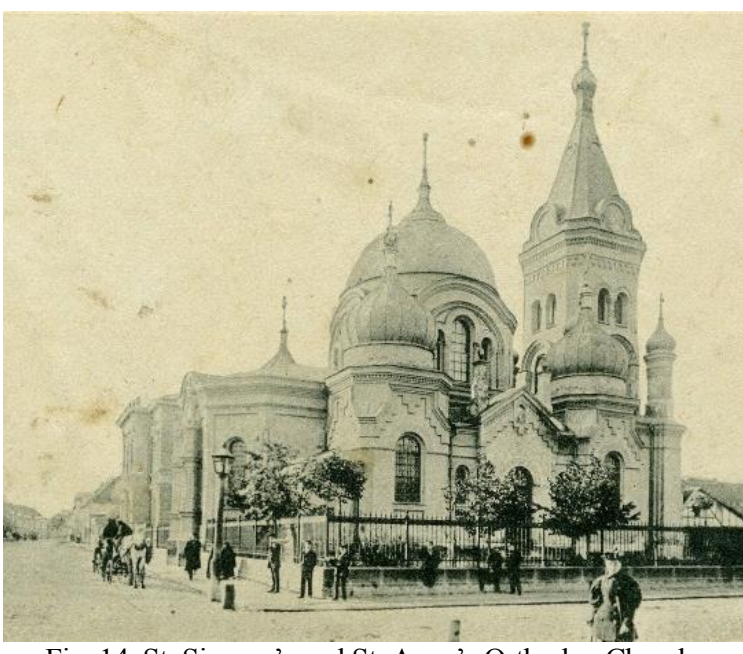

Fig. 14. St. Simeon's and St. Anne's Orthodox Church. The early $20^{\text {th }}$ century [Source: JHAM]

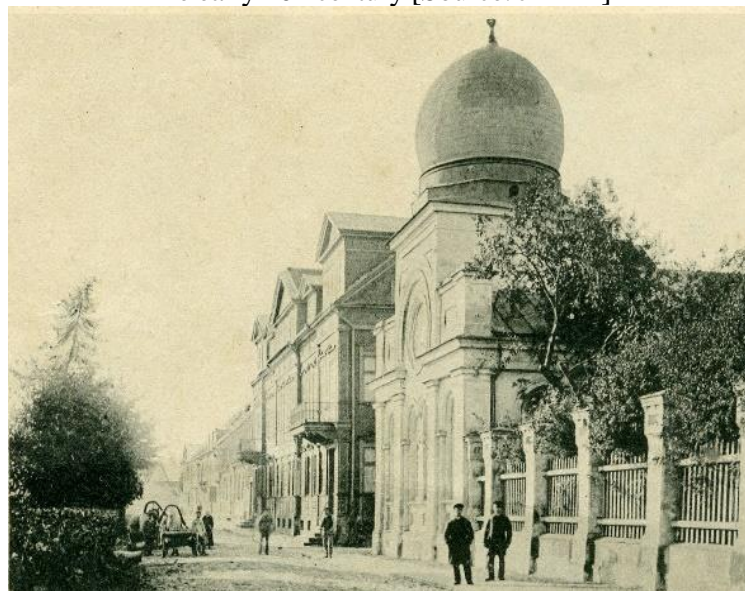

Fig. 15. The synagogue on the bank of the river Driksa promenade. The early $20^{\text {th }}$ century [Source: JHAM]

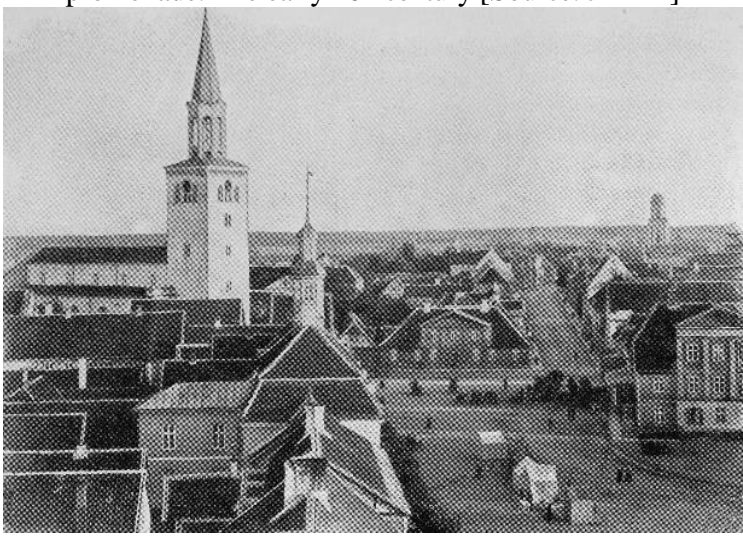

Fig.16. Landscape of the roof of the historic Market Square [Source: JHAM]

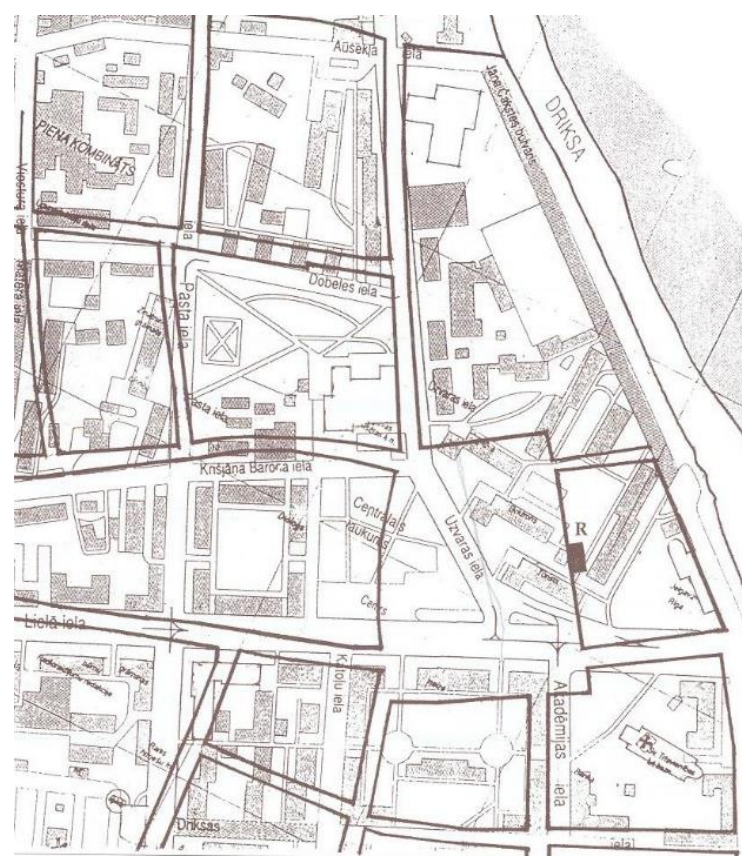

Fig. 17. The comparison of the historic

Market Square and today's street location [3]

The initial shape of the St. Simeon's and St. Anne's Orthodox Church (1892, arch. Chagin) was built according to the sketches of B. F. Rastrelli (Fig. 14). The rebuilding brought new dome and tower forms, keeping only individual fragments of the walls of the church built by Rastrelli $[8,9]$.

The Neo-Gothic tower mentioned in the silhouette of the St. John's Church (1882) was best visible from the railway bridge (see the historical photo). This line of sight is impressive even today. Until the war, when the building height around the place of worship did not exceed two or three storeys, the church spire in the silhouette was also visible from Pasta sala. $200 \mathrm{~m}$ away from the St.John's Church there was Ev. Lutheran Unity Church - the largest church in Zemgale (1904, k. Pēkšēns) mixed Neo-Romanic and Neo-Gothic forms.

By studying the historic carriage road into the city from the side of the river Lielupe, it should be noted that until World War II, it was $50 \mathrm{~m}$ away from the current bridge over the river Lielupe. Consequently, the perception of the southern part of the silhouette in the distant lines of sight was more pronounced. 


\section{Results and Discussion}

Assessing the character of the historic city skyline and skyline of modern building, it can be seen that:

- the height of the high-rise building in some viewpoints hides the church spires, so highlighting new vertical stresses. This is especially true for the southern skyline (building on Akadēmijas street and Driksas street);

- the modern building structure has acquired monotone planes and the plurality of forms in the architecture of the building facades is lost;

- the tiled roof character and the multifaceted roof planes have gone;

- the preservation of exaggeratedly large tree canopies hides the architectural shape of the towers (Ūdens street - Raina street);

- the spires as dominants formed stresses not only in the silhouette but also in the urban planning. For instance, the intersection of Ūdens street with the river Driksa promenade - the synagogue serves as an emphasis; the Reformed Church - as a connection point of Dobeles street with Uzvaras street.

St. Simeon's and St. Anne's Church - as the intersection point on Akadēmijas street; St. George's Church - the intersection of Katolu street, etc.. In turn, the Holy Trinity Church highlighted the corner of the Market Square.

The urban construction planning, its structure, the street network, and the language of the architectural, and compositional forms create a context that in the city's silhouette undeniably plays an important role. Especially brightly, it is attributable to the 2 periods of the construction of the city - in the situation of the prewar and postwar political power.

As in the $40 \mathrm{~s}$ of the $20^{\text {th }}$ century, by the compositional character, it is possible to divide the building of the embankment of the river Driksa in 2 zones: the downstream and upstream over the bridge of the river Driksa. Each of them has a different compositional structure and their length makes a building line about $100 \mathrm{~m}$ in length:

Upstream of the river, the embankment building is made up of a seamless 5-storey building, built in the 60 s of the $20^{\text {th }}$ century. Comparing both building periods, there is a different building height, structure, and form creation of the buildings.

Downstream of the Driksa bridge, the building of the embankment is characterized by a 3-storey hotel. Behind it, there are 5-storey residential buildings, which are positioned inclined against the waterfront. This position makes it possible to the green courtyard area be connected with the tree plantings of the embankment, which, in turn, reduces the expressiveness of the silhouetted building of the urban constructed space. In turn, while studying from the perspective of the ecological diversity and the green recreational space, the residential zone downstream of the Driksa bridge has gained a very strong character of the green area (Fig. 8). It is composed by:

- the courtyard tree plantations, broad lawns, and the green slope along the buildings, which serve as a back filling of the buildings' basement levels;

- the river bank landscape and a row of tree plantations;

- the view lines to the floodplain meadow on the opposite bank.

In the context of the construction of the embankment, the above green landscape is less pronounced in the upper reaches of the river than in the lower reaches. This applies to the placement of larger areas of the hard cover in the upper reaches:

- parking areas, the carriageway, pedestrian walkway, and the cycling area, concrete platforms as playgrounds;

- improvement elements of the pedestrian zone benches, lighting fixtures, design elements;

- the building volumes of the sport, leisure, and recreation area on the opposite bank;

- the exposition of the pedestrian bridge construction.

The compositional structure of the embankment silhouette in the lower and upper reaches has a different context, both in terms of the form creation and density of the green areas. This description has two aspects:

- nowadays, the silhouette of the city down the river Driksa is characterized by a residential area with a wide green landscape space. In turn, up to the $40 \mathrm{~s}$ of the $20^{\text {th }}$ century, there were 2-3-storey building units in this place, with an intensive economic activity alongside - fishing boat moorings and the exit to the Market Square. Alongside with the market pulsation, the Chivalry House belonging to the German nobility was located on the embankment, the architectural and compositional form of which was radically different from that of the building character readable in the silhouette. To a certain extent, both visually and psychologically, it clearly marked the city's German and Latvian peculiarities, both in the political and in the economic life.

Up to the $40 \mathrm{~s}$ of the $20^{\text {th }}$ century, upstream of the river, the modern building line of the embankment with public buildings was a location of residential houses with a walking area. Currently, the building of the silhouette is complemented by a concrete bank with boat moorings (Fig. 9). 


\section{Conclusions}

Like in any city in the world, Jelgava has also been affected by times of economic growth, which is reflected in the urban construction. Through the accumulation of layers of one construction period to another, the change of the boundary lines and stylistics of the construction phases are readable. Unfortunately, in the case of Jelgava, pages of such a history book are not readable, as the point of reference of the building history dates back to the 50 s of the $20^{\text {th }}$ century when the last rubbles of the war were removed from the streets of the city.

The information and assumptions about the church history in Jelgava are mostly based on the publications of Baltic German pastors and historians, the truth of which today is no longer possible to accurately verify. The church history studies in Jelgava have been carried out 140 years ago and during this time archives, libraries, and other important sources of reference have been irretrievably lost.

The changes of the silhouette on the left bank of the river Driksa can be divided into 3 main phases: up to the $40 \mathrm{~s}$ of the $20^{\text {th }}$ century, up to the 80 s of the $20^{\text {th }}$ century, and the start of the $21^{\text {st }}$ century. As mentioned in the research, only the last two phases are readable in the city's panorama. The perception of the silhouette of Jelgava in the viewing lines is influenced not only by the height of the building but also by the density and height of the trees. An important aspect of the silhouette, the location of the points of view is to be mentioned that plays an important role in attracting the infrastructure of tourism. This refers to the tasks of the urban construction planning, considering the opening or preservation of the viewing points, creating new buildings or tree planting zones.

\section{References}

1. Asaris, H. Latvijas pilsētas valsts divdesmit gados. Rīga: Latvijas Pilsētu savienība, 1938, pp. 210-242.

2. Apinis, K. Latvijas pilsētu vēsture. Rīga: A. Gulbis, 1931, pp. 182.-183.

3. Bākule, I. Rātsnami Latvijas pilsētās. Rīga: Zinātne, 2001, pp.107-117.

4. Dērings, J. Ko es nekad negribētu aizmirst. Rīga: Latvijas Nacionālais arhīvs, 2016. 878 p.

5. Grosmane, E. Senā Jelgava. Rīga: Neputns, 2010. 336 p.

6. Lancmanis, I. Jelgavas pils. Rīga: Zinātne, 2006, pp.14-16.

7. Schlau, K. O. Mitau im 19. Jahrhundert: Leben und Wirken des Bürgermeisters Franz von Zuccalmaglio (18001873). Wedemark-Elze: Harro v. Hirschheydt, 1995. 458 p.

8. Spārītis, O. Versija par Jelgavas Sv. Trīsvienības baznīcu. Jelgava: Jelgavas pilsētas pašvaldība, 2011. $334 \mathrm{p}$

9. Tomašūns, A. Mana Jelgava. Jelgava: Jelgavas pilsētas dome, 2015. 224 p.

\section{INFORMATION ABOUT AUTHOR:}

Aija Ziemel̦niece. Dr.arch. A.Ziemeḷniece is an prof. in Latvia University of Agriculture, specialized in fields cultural heritage, study of transformation processes of urban landscape. E-mail:aija@k-projekts.lv

Kopsavilkums. Gan Jelgavas vēsturiskais karšu materiāls, gan senās gravīras liecina par pilsētai raksturīgu siluetu ar daudzām dievnamu smailēm. Attīstoties fotogrāfiskā attēla iegūšanas iespējām, dokumentālais materiāls īpaši spilgti 20.gs 20.-30.g. liecina par vēsturiskā pilsētas silueta izteiksmīgumu. Pateicoties dokumentētajam materiālam, ir iespējams veikt pilsētbūvnieciskās telpas izpēti pa atsevišķām dievnamu apbūves zonām gar Driksas kreiso krastu, kur iepretim hercogistes mītnes vietai - Jelgavas pilij, izvietojās pilsētas vāciskās aristokrātijas lepnākie nami.

Jelgavas siluets ar dievnamu smailēm gadu simtos ir mainījies vairākkārtīgi. Tā arhitektoniski ainaviskās izteiksmes kulminācija pastāvēja līdz otrajam pasaules karam, līdz pilsēta tika nežēlīgi nodedzināta un vēsturiskās apbūves atjaunošana tika ignorēta. Mainoties ǵeopolitiskajai situācijai, mainās līdzi pilsētas apbūves blīvums, augstums un siluets. Jelgava ir spilgts piemērs politiskās varas izpausmēm, kas ir attiecināms nevien uz dievnamu atjaunošanu vai demontāžu 20.gs.50.g. Reizē tas ir divu sabiedrības politisko spēku salīdzinājums sapratnei par pilsētas apbūves kultūrvēsturiskā mantojuma vērtībām. Pēckara gados jēdziens "sapratne” ir ar slēptu nozīmi, iznīcinot t.s. kapitālisma laika mantojumu kultūrā, mākslā un arhitektūrā.

Kā spožākais akcents Jelgavas siluetā pastāvēja vācu ev.lut. Sv. Trīsvienības baznīca, simbolizējot pilsētas garīgo varu. Tai līdzās - administratīvās varas simbols - Rātsnams ar smaili un vācu Bruṇniecības nams. Trīs spēcīgi vāciskās vides simboli Jelgavas pilsētas silueta centrā - skaidri iezīmēja pilsētas kultūrvēsturisko lappusi Driksas kreisā krastā.

20.gs. 20.-30. gadi atnes jaunās Latvijas valsts politisko varu un tās attieksmi pret vācisko pilsētvidi. Varas maiņas izpausmes aizsākas ar Bruṇniecības nama demontāža 20. gs. 30. g. un jaunas viesnīcas būvniecību tajā pašā vietā, ienesot pilsētas siluetā citu akcentu.

Mūsdienu Jelgavas siluets Driksas kreisā krastā ir 20. gs. 60.-70. g. mantojums, kurā ir nolasāms apbūves uzslāņojums pēdējo simts gadu laikā, nesot līdzi jaunu struktūru, mērogu, proporcijas un zaḷo platību blīvumu. 


\title{
Recreation Potential in Ādaži Village
}

\author{
Una Kancāne, Una Īle, Latvija University of Agriculture
}

\begin{abstract}
The desire of inhabitants to choose their residence in Pierīga has become increasingly popular which is proved by the growing number of population in Ādaži municipality. Since 2005 the number of population in Ādaži municipality has increased by $26 \%$. According to the Central Statistical Bureau of Latvia, 10,897 residents were declared in Ādaži municipality on January 1, 2016 [1]. Not only a permanent growth of the number of population has been observed, but also here is the largest share of young people until the age of 15 . Active recreation infrastructure has been established in Ādaži municipality, but it is insufficient due to a rapid growth of the number of population in recent years. The research explored development opportunities of cycling routes in the municipality. Besides, current active recreation provision for children and youth in $\bar{A}$ daži village and its potential zones in the future were studied. The correlation between placement of active recreation zones and residential zones was analysed in order to determine the potential of active recreation in the public outdoor space.
\end{abstract}

Keywords: public outdoor space, active recreation, infrastructure

\section{Introduction}

Ādaži municipality is located in the northeast part of Pierīga region. The municipality borders on Garkalne, Carnikava, Saulkrasti, Sejjas and Inčukalns municipalities. The municipality comprises 12 villages, out of which Ādaži, Kadaga, Baltezers and Garkalne are the largest ones. The administrative centre of the municipality is situated in Ādaži village. The subject of the research is Ādaži village, the centre of Ādaži municipality, which provides for the largest part of the infrastructure in the municipality. The territory has experienced several territorial reforms after the restoration of the Republic of Latvia. In 1997 part of Bergi, Garkalne and Vangaži villages was added to Ādaži. Ādaži village was transformed to a parish before 1991, but the present borders were fixed in 1992, when Carnikava parish was separated from Ādaži parish. In the framework of the administrative territorial reform in 2006 Ādaži parish was renamed

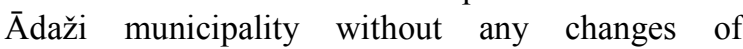
boundaries [2]. Ādaži village, the centre of Ādaži municipality, is located approximately $25 \mathrm{~km}$ from Riga centre; Highway A1 Rīga - Ainaži - Tallina connects it with Riga city. A positive feature for active recreation is the nearby location of two public beaches $-10 \mathrm{~km}$ distance to Carnikava beach and 20 $\mathrm{km}$ to Saulkrasti beach [3]. Consequently, the scheme was worked out on the basis of the infrastructure information taking into account theories on routes in the public outdoor space. One of the main conditions of a healthy way of life is walking, cycling or going by public transport which are healthy and environmentally friendly. J. Gehl, a Danish architect, considers that a comfortable city for a resident is if any destination is reachable in 5 minutes time on foot [4]. A person moves with the speed of $5 \mathrm{~km}$ per hour, it means that
400 metres is possible to cover in 5 minutes on foot. Thus to achieve the aim of the research, and to determine the active recreation potential for children and youth in Ādaži village, the accessibility of playgrounds was studied and analysed in Ādaži village. The potential of active recreation zones was determined during the research in relation to their accessibility radius from residential zones to the potential recreation zones within the territory of Ādaži village.

\section{Materials and Methods}

The research of active recreation opportunities in $\bar{A}$ daži village was conducted in the time period from August 2016 to March 2017. The literature review included the study of publications, electronic resources, space landscape analysis. To achieve the aim, the current situation was studied and analysed in Ādaži village. In addition, the inventory of playgrounds by Ivetas Grīviņa, a spatial development planner, as of 2014 in Ādaži village as well as the information regarding the ownership rights, current structural elements, maintenance of facilities, and the analysis of fun equipment according to users' age group were used to determine potential recreation places. The monographic or descriptive method was used in the research.

\section{Results and Discussion}

In spring of $2016 \bar{A}$ daži the municipality city council worked out the cycling concept which envisaged to develop cycling routes for regular (business) and recreational purposes with plans to integrate cycling routes in the overall traffic infrastructure of the municipality. The new concept envisaged to decrease the share of vehicles and change habits of the municipality residents in 


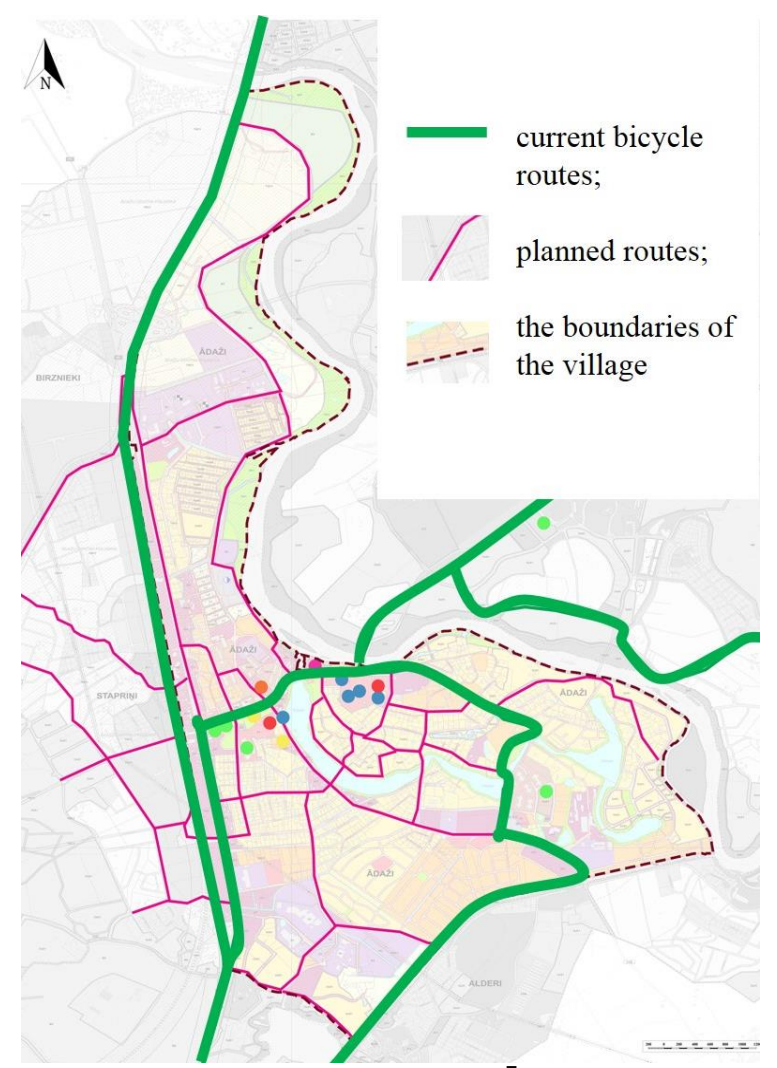

Fig. 1. Bicycle routes in Ādaži

[Source: The scheme made by the authors using the functional zoning scheme of Ādaži municipality]

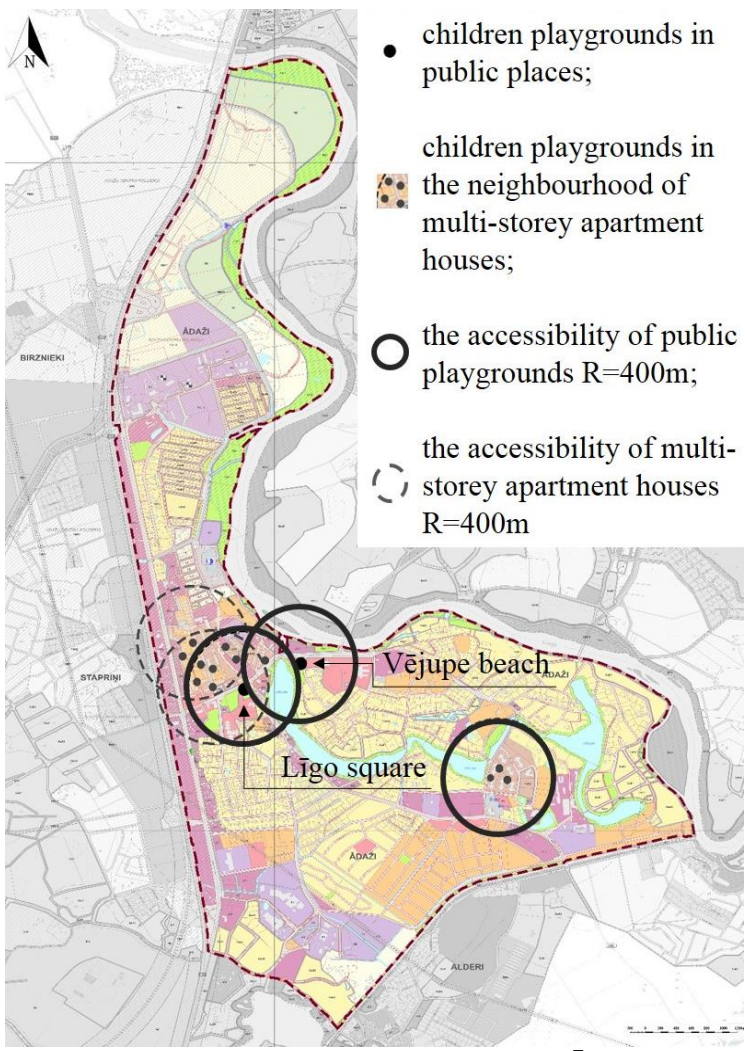

Fig. 2. The location of playgrounds in Ādaži

[Source: the scheme designed by the authors using the scheme of Ādaži functional zoning] reaching everyday destinations (schools, kindergartens, art and music schools, public institutions, shops, production units).

Creation of new cycling routes would promote cycling as part of active lifestyle especially among school children by establishing the net of bicycle routes from densely populated areas to education institutions and recreation places for young people. By increasing the recreation routes it would be possible to provide a comfortable access to recreation areas and to promote the municipality (see Fig. 1). Several business and recreation cycling routes were established for active recreation provision and more comfortable mobility in the municipality; there are also plans to expand cycling infrastructure in the municipality and connect the routes with those of neighbouring municipalities. Three bicycle routes were built in Ādaži municipality: No. 1: Ādaži - Dūņezers - Ādaži (25 30 km); No. 2: Ādaži - apkārt Mazajam Baltezeram - Ādaži $(15$ - 20 km); Nr. 3: Ādaži - apkārt Lielajam Baltezeram - Ādaži $(15-20 \mathrm{~km})$. Construction of cycling routes will continue. The following routes have been included in the development plans: Ādaži - Iḷķene - Old Peterburga road - National route 7; Ādaži - Carnikava beach Eiro Velo 13; Ādaži - Garciems beach - Eiro Velo 13 and others. The cycling society "ĀdažiVelo" actively arranges different cycling races and exciting family events [4].

The accessibility of playgrounds in Ādaži village may be divided into two groups: playgrounds in the territories surrounding multi-storey apartment houses and playgrounds constructed in public places (see Fig. 2). The comparison of the location of playgrounds and functional zoning of Ādaži village shows that playgrounds are mostly concentrated in the areas around multi-storey apartment buildings, and they are used by children of their residents. In 2014 Iveta Grīvina, a spatial development designer, carried out inventory of the current playgrounds which allowed the authors to conclude that each of the visited playgrounds had items of fun equipment suitable for children at the age from 4 to 10. As regards children from 10-12, there is one fun equipment at Līgo square (see Fig. 3). However, such service is provided for children of the area of private houses in the public playground of Vejupe beach, see Fig. 4. Playgrounds in the surroundings of multi-storey apartment houses have standard fun equipment installed on the lawn. At Lìgo square, items of mostly standard fun equipment are installed in washed sand coating, but the public playground unveiled in 2016 at Vejupe beach has interesting solutions for fun equipment, such as "sand factory", and "water games" which are meant for children from the age of 2 and "obstacle course" for children for the age from 4 to 10 . 
The information obtained during the inventory and the detailed information about maintenance companies, as well as the size of items of recreation equipment is summarized in Table 1.

Children playgrounds in the surrounding areas of multi-storied apartment houses create a feeling of private property, and they are far away from residential areas of private houses. Therefore children from private houses do not feel welcomed to use them and socialize with children from multi-storied apartment houses. This function is performed by public playgrounds at Lìgo square and Vējupe beach accessible for everyone, however, their capacity is not sufficient, besides the accessibility radius does not cover the largest part of private houses for children of all ages to use it simultaneously. The analysis of functional zoning of $\bar{A}$ daži village territory shows that public green zone accessible to general public account for $0.8 \%$ of the total area. To provide comfortable accessibility, the accessibility radius of 400 metres was taken as a benchmark for marking of potential zones in Ādaži village. The research selected potential territories for active recreation taking into account the current and planned nature zone and greenery. Consequently, three active recreation areas are suggested in order to provide wider opportunities and functions for active recreation in the planned future residential zones. The point is that active recreation zones should be installed before the design of residential zones.

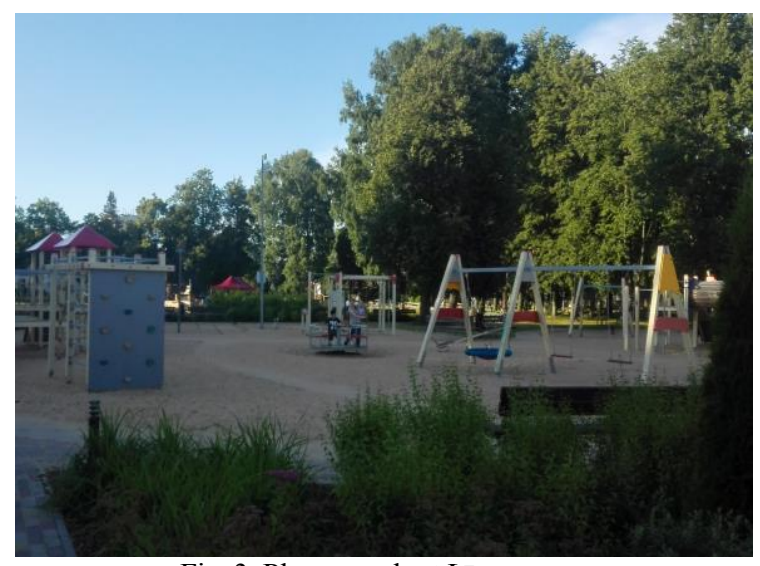

Fig. 3. Playgrounds at Ligo square [Source: U. Kancāne, 2017]

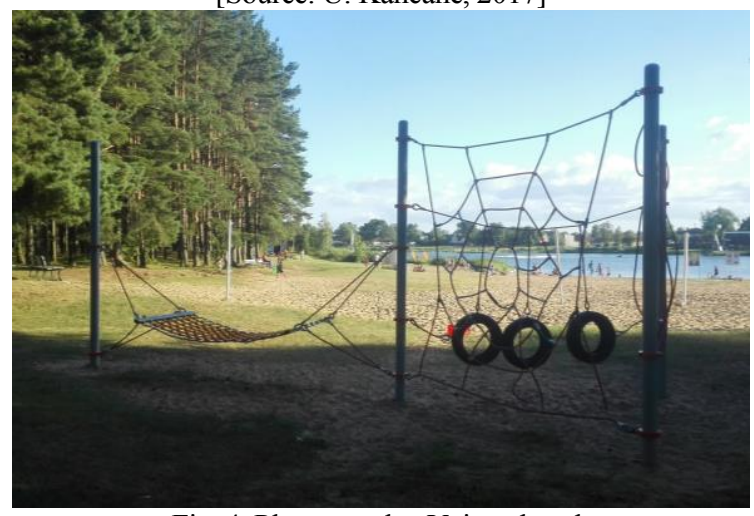

Fig. 4. Playground at Vējupe beach

[Source: U. Kancāne, 2017]

Children playgrounds in Ādaži municipality [Source: I. Grīvinna's materials]

TABLE 1

\begin{tabular}{|c|c|c|c|c|c|c|}
\hline \multirow[b]{2}{*}{ Address } & \multirow[b]{2}{*}{$\begin{array}{l}\text { Land ownership } \\
\text { rights }\end{array}$} & \multirow{2}{*}{$\begin{array}{l}\text { Responsible for } \\
\text { equipment } \\
\text { maintenance }\end{array}$} & \multicolumn{4}{|c|}{ Age groups of users } \\
\hline & & & $2-4$ years & $4-10$ years & $10+$ years & $\begin{array}{c}\text { Sport } \\
\text { equipment }\end{array}$ \\
\hline $\begin{array}{c}\text { Attekas street } \\
20, \bar{A} \text { Aaži }\end{array}$ & $\begin{array}{l}\text { House owners } \\
\text { property }\end{array}$ & House owners & $\begin{array}{l}\text { Sandbox for } \\
\text { kids }\end{array}$ & Swing & - & - \\
\hline $\begin{array}{c}\text { Attekas street } \\
22, \bar{A} \text { daži }\end{array}$ & $\begin{array}{l}\text { House owners } \\
\text { property }\end{array}$ & House owners & $\begin{array}{c}\text { Wooden play } \\
\text { equipment }\end{array}$ & - & - & - \\
\hline $\begin{array}{c}\text { Gaujas street } \\
25, \text { Âdaži }\end{array}$ & $\begin{array}{c}\text { Municipality } \\
\text { property }\end{array}$ & Municipality & $\begin{array}{l}\text { Sandbox for } \\
\text { kids }\end{array}$ & $\begin{array}{l}\text { Playing town, } \\
\text { swing }\end{array}$ & - & - \\
\hline $\begin{array}{l}\text { Pirmā street } \\
\text { 21, Ādaži }\end{array}$ & $\begin{array}{l}\text { House owners } \\
\text { property }\end{array}$ & House owners & - & - & - & $\begin{array}{c}\text { Basketball } \\
\text { shields }\end{array}$ \\
\hline $\begin{array}{l}\text { Pirmā street } \\
\text { 29, Ādaži }\end{array}$ & $\begin{array}{l}\text { Municipality } \\
\text { property }\end{array}$ & Municipality & $\begin{array}{l}\text { Sandbox for } \\
\text { kids } \\
\text { Swing }\end{array}$ & $\begin{array}{c}\text { Play town } \\
\text { playground } \\
\text { Swing, swing } \\
\text { balancer }\end{array}$ & $\begin{array}{l}\text { Climbing } \\
\text { equipment }\end{array}$ & - \\
\hline $\begin{array}{l}\text { Pirmā street } \\
\text { 30, Ādaži }\end{array}$ & $\begin{array}{c}\text { House owners } \\
\text { property }\end{array}$ & House owners & $\begin{array}{l}\text { Sandbox for } \\
\text { kids }\end{array}$ & $\begin{array}{l}\text { Playing } \\
\text { elements }\end{array}$ & - & $\begin{array}{c}\text { Mini } \\
\text { football }\end{array}$ \\
\hline $\begin{array}{c}\text { Pirmā iela 31, } \\
\text { Ādaži }\end{array}$ & $\begin{array}{l}\text { Municipality } \\
\text { property }\end{array}$ & Municipality & - & - & - & $\begin{array}{c}\text { Basketball } \\
\text { hoop }\end{array}$ \\
\hline $\begin{array}{c}\text { Pirmā street } \\
\text { 33, Ādaži }\end{array}$ & $\begin{array}{l}\text { House owners } \\
\text { property }\end{array}$ & Municipality & $\begin{array}{l}\text { Sandbox for } \\
\text { kids }\end{array}$ & $\begin{array}{l}\text { Playing } \\
\text { elements }\end{array}$ & - & - \\
\hline $\begin{array}{c}\text { Ūbeḷu street } \\
\text { 13, Podnieki }\end{array}$ & $\begin{array}{c}\text { House owners } \\
\text { property }\end{array}$ & House owners & $\begin{array}{c}\text { Sandbox for } \\
\text { kids }\end{array}$ & Swing & - & - \\
\hline $\begin{array}{l}\text { Ūbelu street } \\
\text { 15, Podnieki }\end{array}$ & $\begin{array}{l}\text { House owners } \\
\text { property }\end{array}$ & House owners & $\begin{array}{l}\text { Sandbox for } \\
\text { kids, } \\
\text { Kids slides }\end{array}$ & $\begin{array}{l}\text { Play town } \\
\text { with kids } \\
\text { slides, } \\
\text { swing, }\end{array}$ & - & $\begin{array}{c}\text { Exercise } \\
\text { equipment, } \\
\text { Balance } \\
\text { board, }\end{array}$ \\
\hline
\end{tabular}




\begin{tabular}{|c|c|c|c|c|c|c|}
\hline \multirow[b]{2}{*}{ Address } & \multirow[b]{2}{*}{$\begin{array}{l}\text { Land ownership } \\
\text { rights }\end{array}$} & \multirow{2}{*}{$\begin{array}{l}\text { Responsible for } \\
\text { equipment } \\
\text { maintenance }\end{array}$} & \multicolumn{4}{|c|}{ Age groups of users } \\
\hline & & & $2-4$ years & 4-10 years & $10+$ years & $\begin{array}{c}\text { Sport } \\
\text { equipment }\end{array}$ \\
\hline & & & & $\begin{array}{l}\text { large town } \\
\text { with nets }\end{array}$ & & $\begin{array}{l}\text { Volleyball } \\
\text { court }\end{array}$ \\
\hline $\begin{array}{l}\text { Ūbel̦u street } \\
\text { 16, Podnieki }\end{array}$ & $\begin{array}{l}\text { House owners } \\
\text { property }\end{array}$ & House owners & $\begin{array}{c}\text { Playing } \\
\text { equipment } \\
\text { with kids } \\
\text { slides, } \\
\text { Sandbox for } \\
\text { kids, } \\
\text { Game table } \\
\end{array}$ & - & - & - \\
\hline $\begin{array}{l}\text { Lazdu street } \\
\text { 5, Garkalne }\end{array}$ & $\begin{array}{l}\text { Municipality } \\
\text { property }\end{array}$ & Municipality & $\begin{array}{l}\text { Sandbox for } \\
\text { kids }\end{array}$ & $\begin{array}{l}\text { Playing } \\
\text { structure, } \\
\text { Swing }\end{array}$ & - & $\begin{array}{l}\text { Basketball } \\
\text { hoop }\end{array}$ \\
\hline Kadaga 5 & $\begin{array}{c}\text { Municipality } \\
\text { property }\end{array}$ & Municipality & $\begin{array}{l}\text { Sandbox for } \\
\text { kids }\end{array}$ & $\begin{array}{l}\text { Playground } \\
\text { structure with } \\
\text { kids slides, } \\
\text { Swing }\end{array}$ & - & $\begin{array}{l}\text { Volleyball } \\
\text { court }\end{array}$ \\
\hline Kadaga 6 & $\begin{array}{c}\text { Municipality } \\
\text { property }\end{array}$ & Municipality & $\begin{array}{l}\text { Sandbox for } \\
\text { kids } \\
\text { Swing }\end{array}$ & $\begin{array}{l}\text { Play town, } \\
\text { swing, swing- } \\
\text { balancer }\end{array}$ & $\begin{array}{l}\text { Climbing } \\
\text { equipment }\end{array}$ & - \\
\hline Kadaga 7 & $\begin{array}{l}\text { Municipality } \\
\text { property }\end{array}$ & Municipality & - & $\begin{array}{c}\text { Swing } \\
\text { (not working) }\end{array}$ & - & $\begin{array}{l}\text { Basketball } \\
\text { hoop, } \\
\text { exercise } \\
\text { equipment - } \\
\text { not usable } \\
\end{array}$ \\
\hline Kadaga 9 & $\begin{array}{l}\text { Municipality } \\
\text { property }\end{array}$ & Municipality & $\begin{array}{l}\text { Sandbox for } \\
\text { kids }\end{array}$ & $\begin{array}{c}\text { Swing } \\
\text { balancer, } \\
\text { swing }\end{array}$ & - & - \\
\hline Kadaga 12 & $\begin{array}{l}\text { House owners } \\
\text { property }\end{array}$ & House owners & $\begin{array}{l}\text { Sandbox for } \\
\text { kids }\end{array}$ & $\begin{array}{c}\text { Swing, } \\
\text { balancer, } \\
\text { Kids slides, } \\
\text { climbing arch }\end{array}$ & - & $\begin{array}{l}\text { Ic hockey } \\
\text { rink }\end{array}$ \\
\hline Kadaga 13 & $\begin{array}{c}\text { Municipality } \\
\text { property }\end{array}$ & Municipality & $\begin{array}{l}\text { Sandbox for } \\
\text { kids }\end{array}$ & $\begin{array}{l}\text { Playing } \\
\text { structure }\end{array}$ & - & - \\
\hline $\begin{array}{l}\text { Līgo square, } \\
\text { Âdaži }\end{array}$ & $\begin{array}{l}\text { Municipality } \\
\text { property }\end{array}$ & Municipality & $\begin{array}{c}\text { Play car, } \\
\text { Sandbox for } \\
\text { kids, } \\
\text { 4-seat swing } \\
\text { balancer, } \\
\text { swing } \\
\text { balancer (2) }\end{array}$ & $\begin{array}{c}\text { Complex } \\
\text { playground } \\
\text { (2), } \\
\text { Swing with } 3 \\
\text { swings, } \\
\text { balancer, } \\
\text { carousel, sport } \\
\text { equipment (2), } \\
\text { Rotating } \\
\text { carousel, } \\
\text { excavator }\end{array}$ & $\begin{array}{c}\text { Rope } \\
\text { pyramid }\end{array}$ & - \\
\hline
\end{tabular}

New areas for building private houses are indicated closer to Mazais Baltezers lake in the territorial zoning, however, the planned active recreational zone is located outside the village territory to provide a function for new areas of private houses. The functional zoning of Ādaži village envisages formation of multi-stories apartments in the neighbourhoods of Saule and Puku streets. Currently this territory comprises several private houses and agriculture land. The population growth is forecasted in this territory, therefore a potential active recreation zone was marked during the research, the radius of which includes neighbouring private houses and planned multi-storied apartment houses, see Fig. 5. The formation of an active recreation zone in this location would keep the green structure of the vicinity as well as provide residents with a publicly accessible area.

The second potential active recreation zone (Fig. 5., Zone No 2) would be located in the green zone of planned multi-storied apartment houses and private houses, it is located close to planned public building territory. Currently there is agriculture land, see Fig. 6. At present the territory of Zone No 3 (see Fig. 7) is covered by the forest. In order to maintain the landscape and its quality characteristic to the territory, it would be necessary to arrange a corresponding active recreation area. The design of this area should be carefully planned with preliminary inventory of trees with the focus on the 


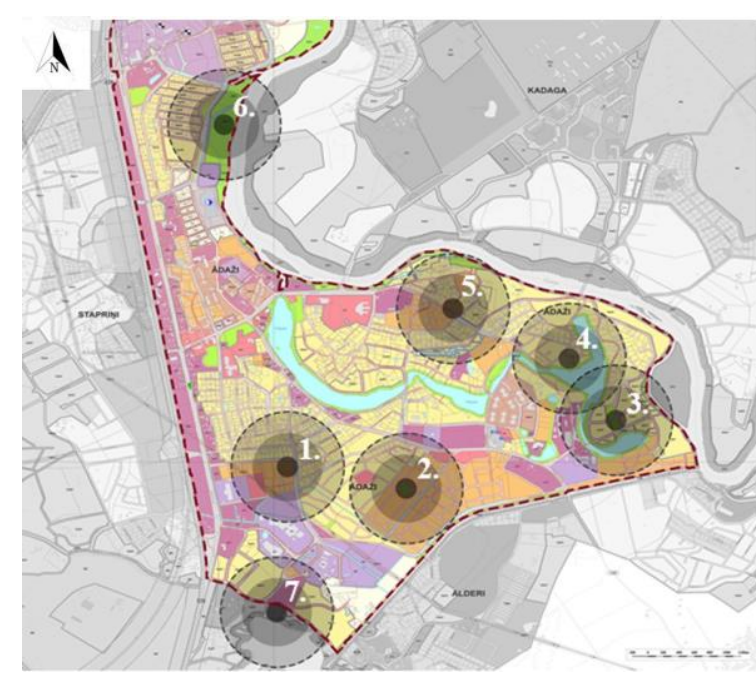

Fig. 5. Active recreation potential zones

[Source: the scheme created by the authors using functional zoning scheme of Ādaži municipality], 1 till 7 potential recreation places and active recreation zones; accessibility is $\mathrm{R}=400 \mathrm{~m}$

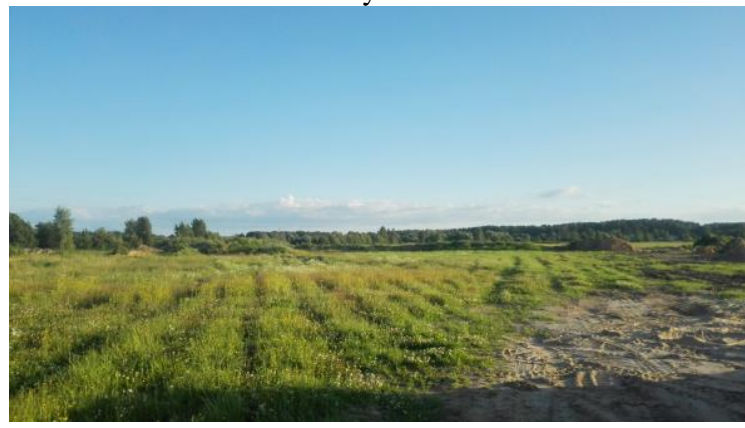

Fig. 6. Agricultural land as the potential Zone No 2 [Source: U. Kancāne, 2017]

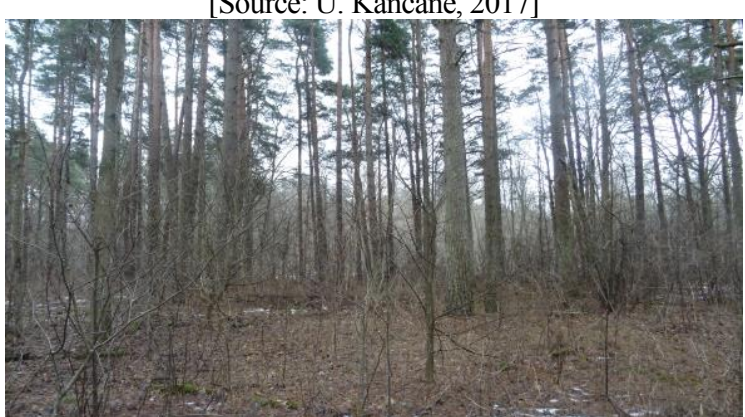

Fig. 7. Potential zone No. 3 for formation of an active recreation area [Source: U. Kancāne, 2017]

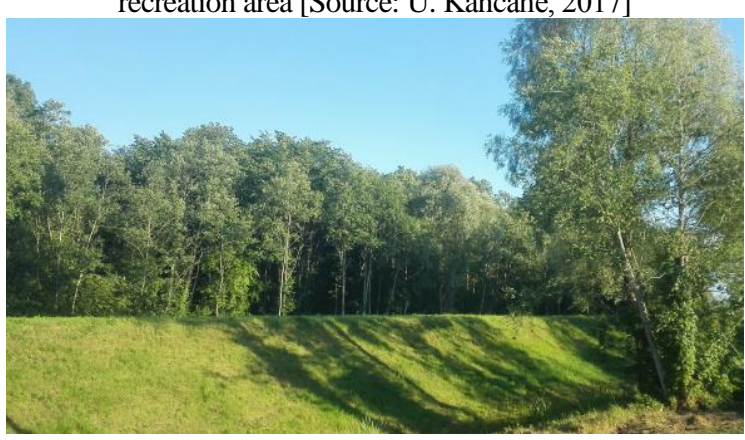

Fig. 8. The present scene to the Gauja behind the scrubs. Potential Zone No 6 for creating a publicly accessible recreation area [Source: U. Kancāne, 2017] forest area by integrating well-thought structural elements and adjusting relevant design linked with forest images. Thus it would be possible to achieve a specific place identity and integrate innovative design in the public outdoor space.

The fourth potential area No 4 currently is agricultural land, and it is located on the bank of Vejupe (Fig. 5, Zone No 4). As it is seen both in the current and planned zoning, this territory is envisaged for building private houses. A close distance of water is especially attractive for residents therefore it is possible to develop this place as a swimming place. It would be necessary to clean the bank of the river from scrubs, regular mowing would create a beautiful scene of the river and would provide access to the water.

As regards Zone No 5, the zone between two streets, Gauja and Skujas (see Fig. 5), is currently managed only by means of mowing the grass as it is surrounded by a large area of privately owned houses. The development of active recreation opportunities in the area would encourage neighbours to communicate, socialize and use public outdoor space of good quality for recreational activities.

The sixth potential territory has been selected in the region of Ādaži manor (Fig. 5, Zone No 6). The inspection of this territory allows to conclude that they are badly maintained and cleaned. These are private territories having signs created by residents themselves: "Private property, do not throw out litter", see Figures 8 and 9. The place would acquire the new identity if someone cleaned this area thus revealing a wonderful scene to the river line. Then residents would be more concerned about the order and cleanliness in this public outdoor space. The analysis of the relief and security of the place suggests that it is possible to develop modern and innovative attractive and accessible public outdoor space.

The seventh potential area has been selected outside the territory of Ādaži village (Fig. 5. Zone No 7), however, it is located in Ādaži municipality. Thus it would expand and form the link among the residents of municipality with different active and recreational opportunities and modern solutions in the public outdoor space. Since the territorial planning envisages development of the territory of private houses, the evaluation of the needs for active recreation zones suggests that the residential area of private houses could become more attractive with recreation places on the shore of Maizais Baltezers lake, see Figure 10. 


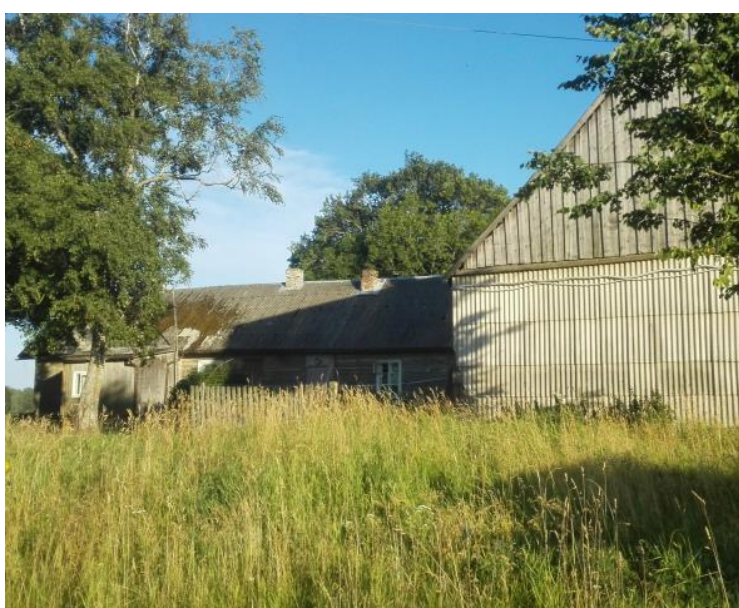

Fig. 9. The territory of Ādaži manor [Source: U. Kancāne, 2017]

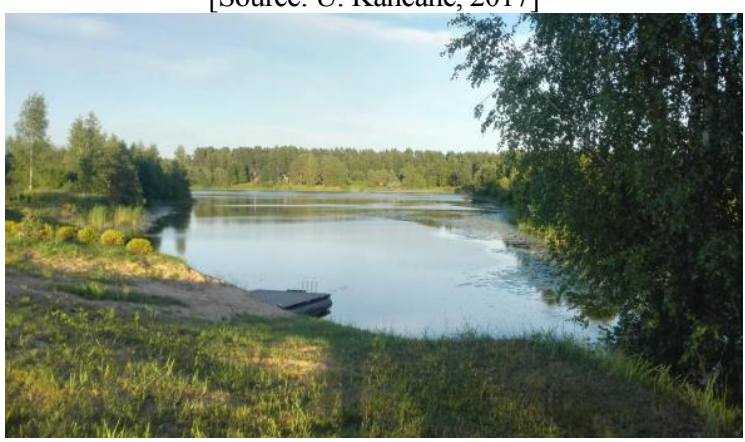

Fig. 10. The shore of Mazais Baltezers lake for development of Recreation Area No 7

[Source: U. Kancāne, 2017]

\section{Conclusions}

In Ādaži village there are 12 children playgrounds in the areas surrounding multi-story apartment buildings and 2 playgrounds in the public places, Līgo square and Ādaži beach, for provision of active recreation of children at the age from 0 to 12 years. Children playgrounds in the surrounding areas of multi-story apartment houses create a feeling of private property and they are far away from residential areas of private houses. Therefore children from private houses do not feel welcomed to use them and socialize with children from multi-story apartment houses. These functions are provided by playgrounds at Līgo square and $\bar{A} d a z ̌ i ~ b e a c h$, but their accessibility radius does not reach the majority of residential areas of private houses.

The designed plan of locations for the active recreation opportunities would provide residents with wider choice of recreation infrastructure in Ādaži village. The proposal of new zones was based on the principle of comfortable city planning which would offer easy accessibility to objects. Zoning of potential active recreation would keep the green zones in Âdaži village, besides, the territory management plan could include cleaning and improvement of these territories to become more user-friendly and secure for residents of Ādaži village.

\section{References}

1. 16 Latvijas novados audzis iedzīvotāju skaits [onlaine 1.06.2017.]. http://www.csb.gov.lv/notikumi/16-latvijasnovados-audzis-iedzivotaju-skaits-45208.html

2. Bauere, I. Ádaži. Novads un ļaudis, Madona: Madonas poligrāfists, 2006, 208 lpp.

3. Ādažu novada dome, Ādažu novada attīitības programma (2016 - 2022). I sējums Esošās situācijas raksturojums [online 21.12.2016.]. http://www.adazi.lv/upload/attistibas_programma/attistibas_programma_i_dala_26.01.2016..pdf

4. Gehl, J. Cities for people, Washington, DC: Island Press, 2010, pp.19.-54.

5. Novada raksturojums [online 22.11.2016.]. http://www.adazi.lv/novads/novada-raksturojums/

Una Kancāne, landscape architect (since 2017), graduate Faculty of Rural Engineers, Department of Architecture and Construction of the Latvia University of Agriculture, 22 Liela iela, Jelgava, Latvia, LV-3001. From 2015-2016 study in Denmark, University of Copenhagen and Hungary, Corvinus University of Budapest. Research presented in $12^{\text {th }}$ International Scientific Conference "Students on Their Way to Science”. E-mail: una.kancane@gmail.com

Una İle, Dr. arch., Assist. Prof. (since 2012) at the Faculty of Rural Engineers, Department of Architecture and Construction of the Latvia University of Agriculture, 22 Liela iela, Jelgava, Latvia, LV-3001. E-mail: una.ile@1lu.lv

Kopsavilkums. Pētījumā izpētītas Ādažu novada mērogā veloinfrastruktūras attīstības iespējas. Savukārt, Ādažu ciemā - izpētītas bērnu un jauniešu aktīvās atpūtas nodrošinājums šobrīd un to potenciālās zonas nākotnē. Analizēta sakarība starp aktīvās atpūtas zonu izvietojumu un dzīvojamām zonām, lai noteiktu aktīvās atpūtas potenciālu ārtelpā. Pētījumā konstatēts, ka Ādažu ciemā bērnu aktīvās atpūtas nodrošināšanai vecuma grupā no 0-12 gadiem ir izveidoti 12 rotaļu laukumi daudzdzīvokḷu namu teritorijās un divi rotaḷu laukumi publiski pieejamās teritorijās - Līgo laukumā un Ādažu pludmalē. Izveidotie rotaļu laukumi daudzdzīvokḷu namu teritorijās rada privāta rakstura atmosfēru un ir lielā attālumā no savrupnamu teritorijām, tādā veidā liedzot bērniem no savrupnamu teritorijām tos izmantot, socializēties ar bērniem no daudzdzīvokḷu namu teritorijām. Šādas funkcijas nodrošina Līgo laukuma un Ādažu pludmales rotaḷu laukumi, kuru sasniedzamības rādiuss neaptver lielāko daḷu savrupnamu teritorijas. 


\title{
Krimulda Church and the cultural and historical environment around it
}

\author{
Jānis Zilgalvis, Dr. arch., a full member of the Latvian Academy of Sciences
}

\begin{abstract}
Krimulda Lutheran Church is located at Krimulda Parish of Riga Region. Together with the rectory building, the place of worship is included in the list of the State protected cultural monuments. Over time, the cultural and historical environment consisting of historical evidence archaeological sites, landscape elements, etc.. In the vicinity of the church has little changed, the spatial structure of planning is also retained. With regard to today's activities, it must be ensured that the environmental quality is not compromised. That's why its research remains topical and necessary in the broad neighborhood context.

Keywords: protection and preservation of the architectural and cultural heritage, landscape architecture,
\end{abstract} protection of the cultural and historical environment

\section{Introduction}

Churches are one of the most typical components of the Latvian rural architecture and landscape. Over time, many buildings of this typological group have been destroyed, demolished and have collapsed. Despite the fate, other ones have reborn and serve the needs of the modern society. The nearest and distant cultural and historical environment of this place of worship consists of a range of historical, architectural, and archaeological evidence. Each of them has its own meaning and connection to the church, including the parsonage building which consisted of not only the pastorate but also of other buildings such as the servant house, stable, cattle-shed. A specific role in the creation of the expressiveness of the ensemble was also played by the landscape and natural elements - the terrain, road network, separate plantations, and their arrays. This applies to Krimulda Lutheran Church the surroundings of which are particularly rich in cultural and historical evidence. A large proportion of them is a story of the survival and their cultural space has kept its authenticity. It is a value which must be protected and defended of thoughtless formations or works. Therefore, the need was urgent to focus on the research of the ancient place of worship in a broader environmental context.

\section{The history of construction of the church}

Krimulda (Kremon) Church is now the oldest, recognized as serving to its task church in Latvia. The building was built from 1205 until 1206 from boulders and dolomite, its oldest part, attributable to the $13^{\text {th }}$ century, is the altar part. It is covered with a dome-shaped arching divided into eight sectors. Originally, the rib bricks were rough and contrasted with the white vaulted sails. Over time, the ribs and vaults were covered with lime mortar and during the repairs of 1902-1905 with a thick cement mortar that changed their subtlety. The sacristy adjoins the

northern wall of the altar room where there are two rooms. The sacristy was built simultaneously with the altar room and it is already mentioned in the documents of 1207 . At the end of the $19^{\text {th }}$ century, its was extended. The church has one nave, the congregation room is covered with a barrel vault, from the altar part it is separated by a wide triumphal arch. The long life of the church is full of events. Originally, it was called Kubesele Church and it was built under the leadership of Priest Alebrant (Alobrandt), soon after returning of Caupo from his trip to Germany and Rome. The name of Kaupo is mentioned in the Chronicle of Henry of Livonia in 1200 and he was called the Liv King of Turaida (Treyden) Municipality [1]. It is possible that his ashes (he was killed in the battle of 1217) were buried in the altar part of Krimulda Church.

In 1630, the church had no rafters and the roof, and only the ridge was covered with straw. Around 1640, the Riga builder Jirgen Horn (J. Horn) restored the church. In the audit documents of 1643 , it is found that the church is ready, just without having the ceiling - so the restoration works continued to be sluggish. In 1669, it is mentioned that the church is still without the ceiling and the bell is hanging on scaffolding erected on the hill. In 1699, the builder and carpenter Henrich Vede (H. Vede) built a baroque tower, installed a roof, made windows. The indoor spaces were also fitted out. In 1701, the openings were widened. In the same year, the Riga master Lars Nilson Spaak (L. N. Spaak) corrected the church walls, built three pediments with fachwerk, a number of low and narrow window openings were made wider and higher [2]. In the subsequent years, repair works were carried out several times. The church is depicted in the drawing made in 1794 by J. Ch. Brotze (J. Ch. Brotze) [3]. It shows a little 


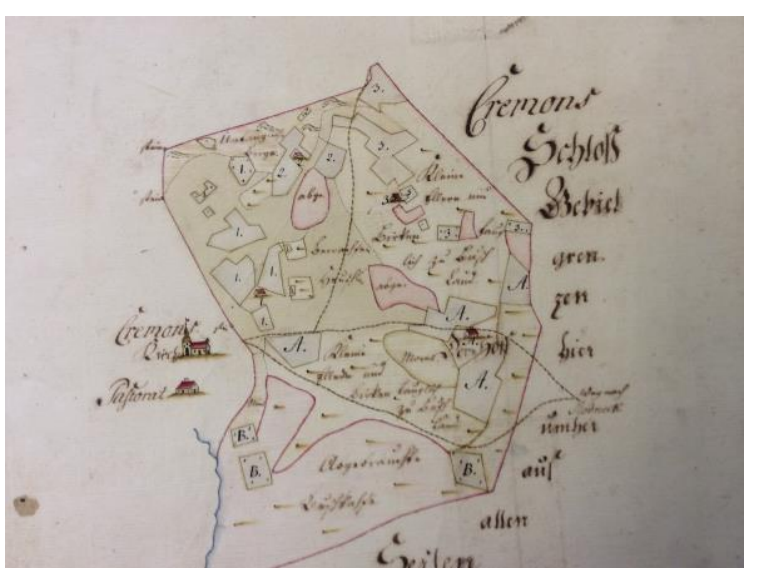

Fig. 1. Krimulda Municipality and Ķizbele Manor with peasant farmsteads [Source: Latvian State Historical Archives, 7404.f., descr. 1, p.146]

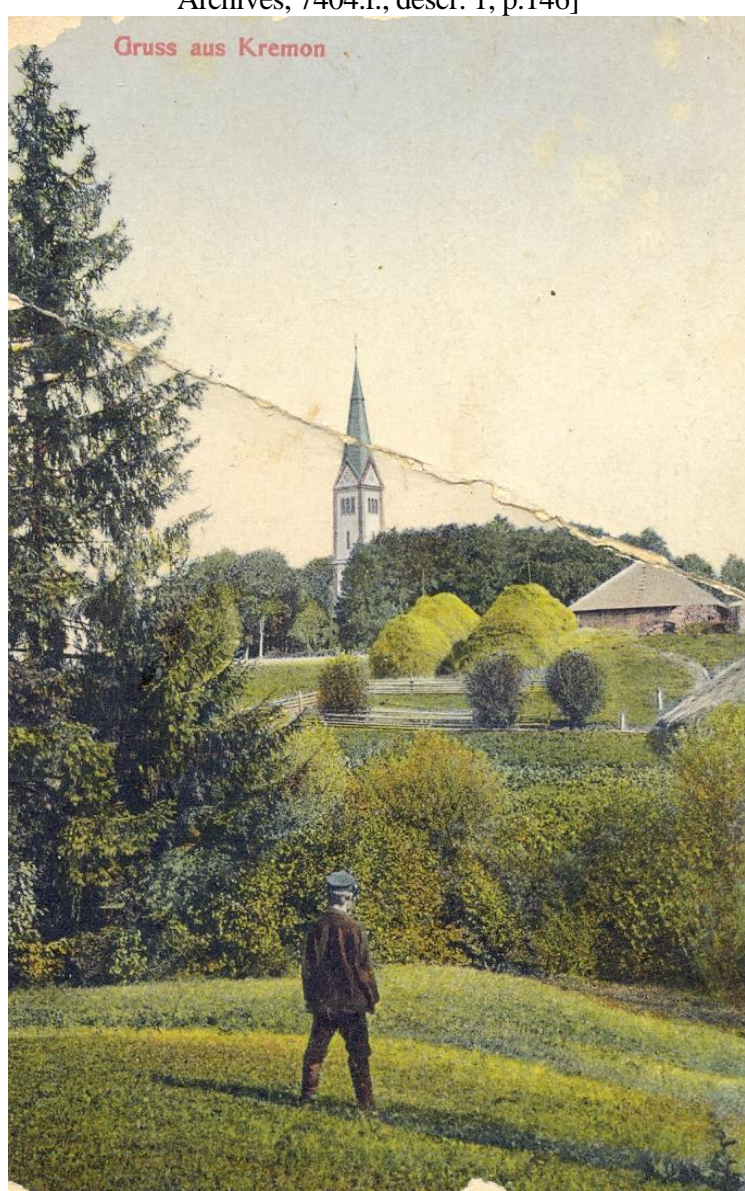

Fig. 2. The landscape of Krimulda Church

[Source: State Inspection for Heritage Protection of the Republic of Latvia, Monument Documentation Center, the 1900s]

stone church with the altar end and the sacristy extension. Above the roof ridge, there is a small polygonal turret with a baroque spire crowned by a ball with a cock. The main entrance of the church is accentuated by a perspective portal in the late Romanesque forms. On both sides of it, niches with the same semi-circular lintel are visible. On each side, the congregation room is illuminated by three windows but the chimney rises above the sacristy. In that year, the second drawing was made by
J. Ch. Brotze where the church is visible from the other side [4]. From it, we get to know that a small extension with an entrance and the side load of the cover were provided by two buttresses. Both drawings by J. Ch. Brotze were made at a time when Pastor Karl Emmanuel Pegau (K. E. Pegau) served at the congregation. In 1816, he was changed by Pastor Karl Christian Ulmann (K. Ch. Ulmann) who later became a professor of the University of Tērbata and from 1840 until 1841 he was its rector.

In 1865, thorough repairs of the church were made - the pulpit was moved in another place (the current one), the triumphal arch was significantly widened, a new plaster ceiling was installed, benches and doors, new floors were partially installed, the walls were painted, etc.. There was a basement below the church which was completely walled up. In 1898, the dressing chamber was expanded by rebuilding the chamber into space for children to be baptized and newlyweds. The following year the repairs of the church were made - the altar room was painted, the old glass of the windows was replaced by new stained-glass windows made by Ernst Tode (E. Tode,1858-1932) in his workshop in Riga. The works were financially supported by the owners of Bīrini (Koltzen) and Sējas (Zögenhof) Manors, as well as by the Latvian church members. Already in 1899, it was decided to build a new church tower. In 1902, the foundation was laid and it was finished in 1905. The construction works were led by the construction master from Sigulda - Jēkabs Ozols. The tower project was developed by the architect August Reinberg (A. Reinberg, 1860-1908). In architecture, the formal direction of the eclectic style dominated - the so-called brick style. On the background of the lightly tinted walls, elements formed in the brick- lay pattern were highlighted - eaves, arcades, window isle borders. The first floor of the tower with the prospective portal and the stairway extension on one side was built entirely of bricks. In order to architecturally link the new tower with the historical volume, small ornamental corner turrets and a rhomboidal belt below the sides of the pediment were created the same as on the tower and the stairway extension facades.

The church greatly suffered in 1917 and 1918, the tower was gunshot, the window panes were broken, almost all of the old historic church equipment items were dragged out. Only the big silver bowl (1768) and the small altar hanging were left over. In 1920, the church was brought in proper order. In 1929, on behalf of the Board of monuments, the architect Pēteris Ārends studied the church, carried out photo fixation and measurements. He has also described art items, such as the altar hanging of dark red velvet with 


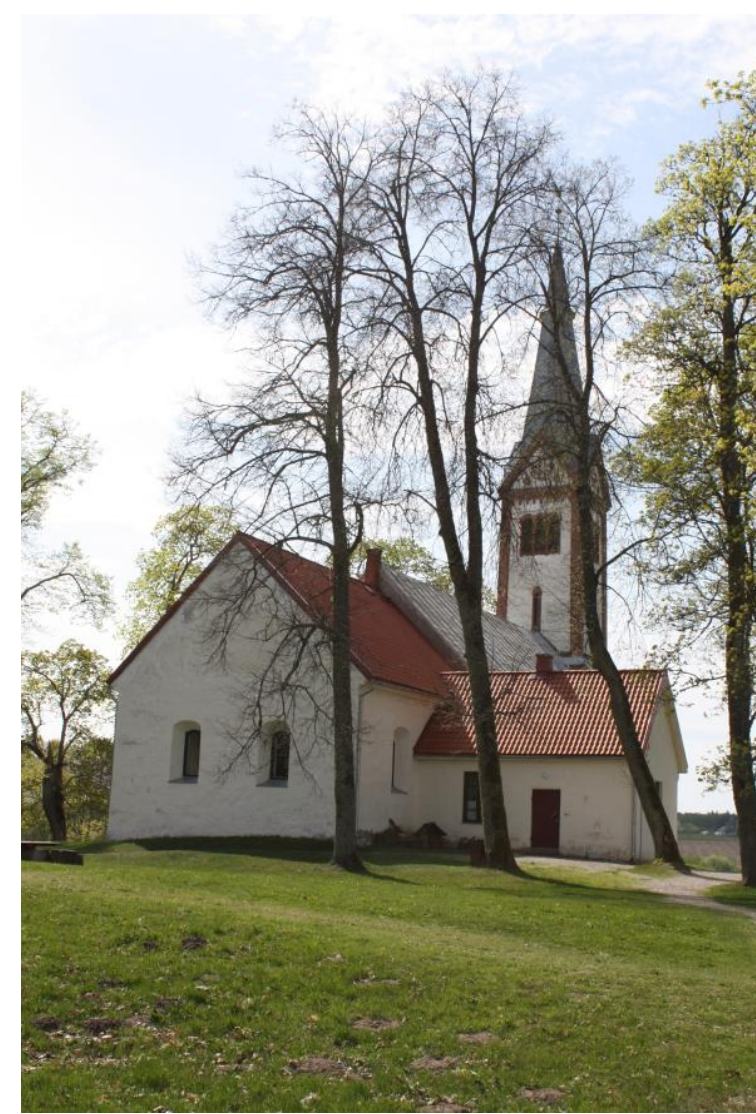

Fig. 3. Krimulda Lutheran Church [Source: photo by author, 2016]

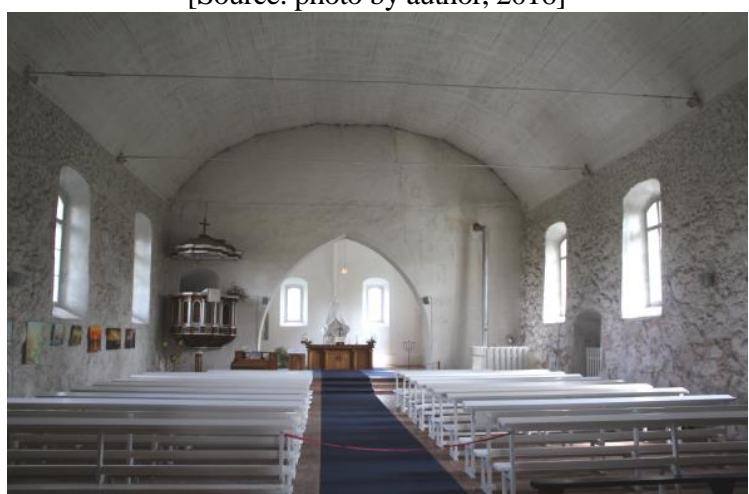

Fig. 4. Krimulda Lutheran Church

[Source: photo by author, 2016]

a white silk lining, with golden fringes. In the middle, a cross sewn in gold, around it ivy and laurel leaf garlands are sewn on from lighter greenish yellow velvet. On the other side, under the lining - "Catharina von Dahl, geb. von Wilcken. Engelhardshoff, den 25 sten Mai 1867."

\section{The fate of the church during the Soviet times and later}

During World War II, the church did not suffer. In 1949, a list of the items of the cult was drawn up. It included two electric chandeliers, two baptismal fonts, the collection plate, four candelabras with multiple arms, two candlesticks with one candle, three tablecloths, a flower vase, carpets, wooden boards with numbers, two old wooden tables, six old damaged chairs, worn velvet runners, an old hearse, an old metal goblet, a dish, an old Bible, song books, a carafe, a glass and a tray [5].

In 1953, a list of the architectural inventory is drawn up. The above mentioned wooden loft, the altar with a crucifix, the old altar with three paintings (1724 and 1865), the pulpit with the caret,13 parishioner benches, a damaged pipe organ and a steel bell [6]. During this year, the survey of the building's architectural and constructive elements is also carried out. It is mentioned that the technical condition is satisfactory, the floor - of the red brick screed, the boards are painted in the congregation room, the walls are plastered but damaged in the dressing chamber and the congregation room from leaking of the roof left not repaired, the vault of the altar part is painted in the shades of pink, in some places the plaster has fallen from the cylindrical vault of the congregation room due to the damaged roof, the windows are glazed, only one is broken in the tower entrance, the organ is damaged, the old altar has three oil paintings [7]. As a result of the survey, the above-mentioned drawbacks are demanded to be eliminated.

In 1960, in the result of the pressure from the Soviets power, the church was closed and the congregation was liquidated. The tribulation time started. In 1966, the remaining parts of the pipe organs were collected from Birži (Buschhof), Vārkava (Warkau) and also from Krimulda, and stored in Jēkabpils. By the initiative and support of the District Party Committee and the District Executive Committee, it was decided to build-in a concert organ on the balcony of Oškalna Culture House in Jēkabpils, using the above-mentioned remaining parts and parts of pipe organs from other congregations. But it was not enough for the remaining parts and the cultural activists of Jēkabpils District turned to the Ministry of Culture to get permission to get the pipe organ of Lielstraupe Church being in a quite good condition.

The congregation was renewed at the end of 1988. The revival of the place of worship was initiated by Kaspars Dimiters who presided over the congregation. In 1996, the building was already under the roof, the indoor space was fitted out, benched were bought, later the pulpit was restored [8]. In 1991, during the repair works of the church, the archaeological monitoring was carried out (archaeologist Jānis Ciglis). Before installing a new brick screed, it was necessary to study the breached and vandalized stairway located in the altar part of the church. One crypt with two burials was studied where two adults and one child were buried. The burials date back to the $17^{\text {th }}, 18^{\text {th }}$ centuries. It should be noted that until the autumn of 1990, the church was in the balance sheet of Gauja National Park. It was held in control of the above park in 1978 as an orphan site and it was the initiative of the 
administration of Gauja National Park. Before, the scientific and research farm "Krimulda" had to take care of the building but nothing was done. In 1992, the repair works of the congregation room of the church were carried out. It had no floor, no windows, the exposed walls helplessly stared towards you and the places of the beam ends evidenced of the former existence of the loft. In 1994, a Catholic congregation was founded in Krimulda and the Lutherans had to conclude a contract with the newly founded congregation of the property sharing.

\section{The church equipment and the interior}

Also, each of the church equipment items has its own story. The old altar appears several times in the photos of A. Birznieks taken in 1920. In its center, the altarpiece "Christ on the Cross" was placed, at the bottom of the altar - in the predella - The Last Supper representation but at the top, the baptismal of Jesus was displayed. The architectural part of the retable consisted of two round freely standing columns on podiums which were supported by a richly profiled eave. The two edges were decorated by strands of acanthus leaves. Above the eave supporting the columns, ball-like decors were placed and the same was also on the top of the retable. These elements were also raised on podiums. The altar was made in 1724 and restored in 1865. It was the given as a gift by the owners of Grāve (Gravenhof) Manor. The pulpit is the evidence of the Baroque time (the first half of the $18^{\text {th }}$ century,). Its body is polygonal, it is surrounded by richly profiled eaves - one along the top, two at the bottom. In each plane of the body, 11 painted blocks were built in. Their shape is rectangular, with a profiled semi-circle top. Round columns are placed in the facets of the body that support the projection of the upper eave. The built-in panels of the pulpit depict the Apostles and Jesus Christ to his full height. In general, the brownish and grayish tones dominate in the paintings. The images of the Apostles are painted in brighter colors. For instance, St. Paul, who is leaning on his sword, St. Peter with keys and an open book in his hands, etc.. In the Soviet times, when the church equipment was destroyed, fragments of the pulpit were delivered to the museum of Rundāle Palace. In 1995, the congregation had an intention to get the above mentioned back from the museum and to reconstruct the pulpit, eight paintings had survived in good condition. This work was accomplished in 1996 and the pulpit began to serve the purpose. The body and the roof were made anew as copies because they were in poor technical condition but the paintings have returned to their places.
The new altar, which was installed in 1870 , was formed by a crucifix placed on the mensa. As a copy of the sculpture made by the Danish sculptor Bertel Thorvaldsen (B. Thorvaldsen, 1770-1844), it was made by his student Johann Nepomuk Zwerger (J. N. Zwerger, 1796-1869). The crucifix was given as a gift by the owner of Bīrini Manor - August von Pistohlkors (A. von Pistohlkors, 1822-1886). It perished in the 1960s. In 1996, several sculptures were made - Our Lady, Saint Francis of Assisi and Thinker which were placed in the church. In the altar part, behind the mensa, the sculpture Christ Invites (1996, sculptor Grair Avertyan) was placed. The oak altar table, covered with a granite slab, was installed in 2004 (the interior decorator Maija Avota).

In 1823, the organ was made by Johann Christoph Kristin of Katlakalns. Later, it was sold as unuseful to Jerrkuli School but in 1910 a new organ was built by the firm of Emil Martin (1848-1922) which in 1917 was demolished. In 1926, a new organ made by the Riga organ construction firm $\mathrm{H}$. Kolbe and J. Dūrējs was consecrated. Its fate is already mentioned above.

The old church bell was cast in 1635 , in Stockholm but in 1977 it was broken and in 1878 was recast by J. Schwenn. In 1895, a new bell was consecrated, making of which was funded by both congregations of Krimulda - the German and Latvian ones. It was made in Germany, Bochum. During World War I, by the Government order, the bell was evacuated to Nižnijinovgorod in Russia and back into 1922 [9].

Until World War II, in the altar room above the door that leads to the pastor's room a black stone plaque was affixed with the inscription - Anno 1205 im 8 ten Jahre des 3 ten Rigischen Bischofs Albert Buxhoweden zu Apeldern ist hier zu Cubbesele bey der Burg des Livischen aeltesten Caupo diese kirche, nachmahls Kremon genant vom priester Alobrandt erbaut worden ...

\section{The rectory}

The rectory is located in the immediate vicinity of the church. The rectory is a distinctive sample of the wooden architecture of the Classicism period. According to the information available by the priest Jānis Ërmanis (1862-1932), it could be built by the initiative of the owner of Krimulda Manor - von Helmersen in 1775 [10]. The building is a log house with a steeped pitched roof, the ends of which are partially oblique. Two porches can be seen in one longitudinal facade near the entrance, in the other one a portico was located. Originally, there was only one porch - verandah on the right side [11]. The construction form of the building is traditional, gently rounded, rather unwieldy. The old classical door sashes were valuable monuments of art (the first half of the 19th century) which have now 


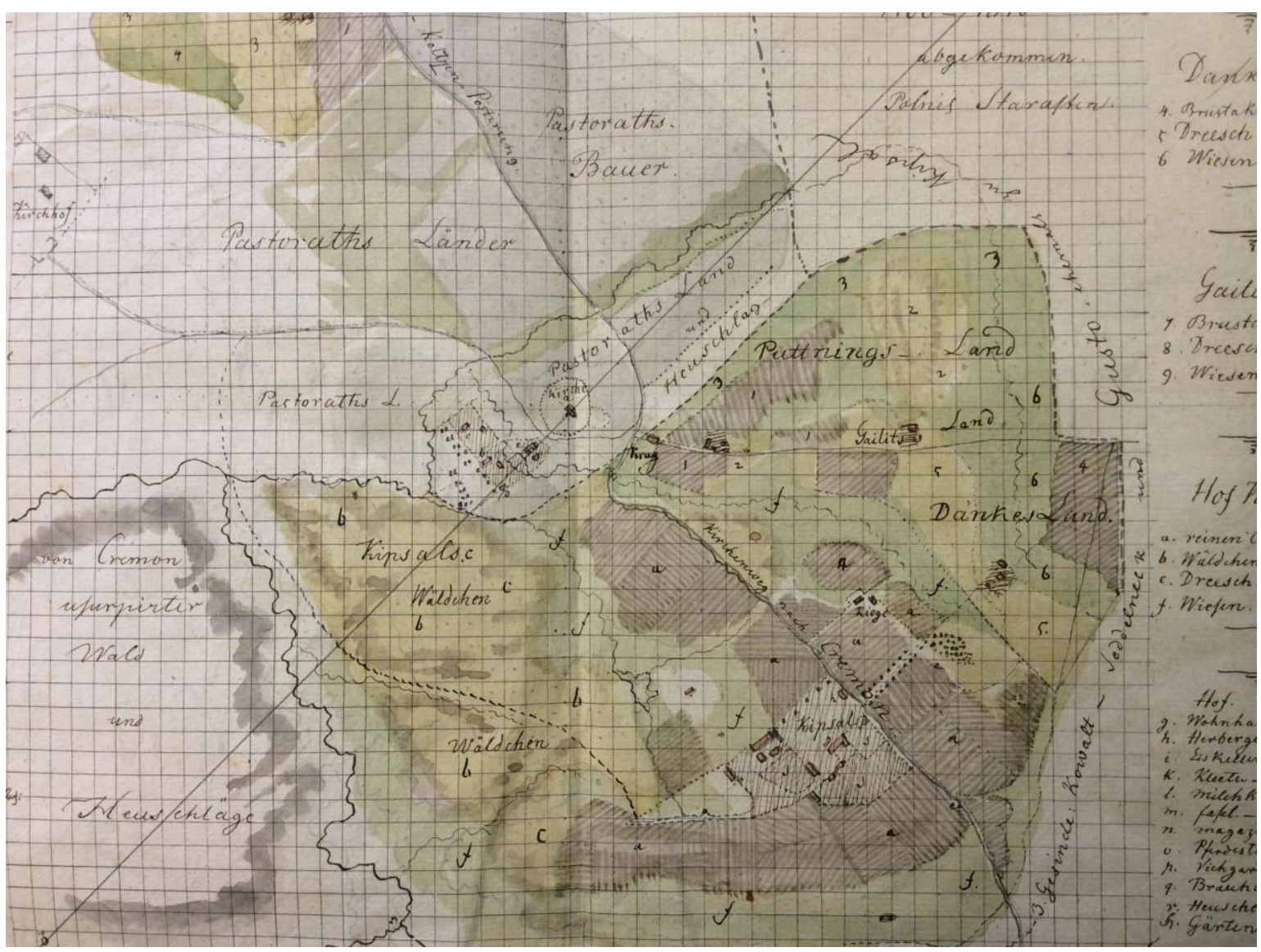

Fig. 5. Kizbele Manor and the layout of the parsonage situation. 1821. A drawing by J. V. Krause

[Source: Latvian State Historical Archives, 6828.f., descr. 6, p. 4430]

been replaced by new, similar ones. In 1980, thanks to the activities of Kaspars Dimiters, the pastorate experienced a revival. In 1912, the pastor J. Ërmanis opened a library there with 262 volumes. Through offering valuable books, its purpose was to combat corn trashy books. The library was devastated in 1917. In the context of the Krimulda congregation, Cross School Book written by the local teacher Juris Natanaēls Ramanis (1797) should be mentioned - a collection of various essays, the rebellious nature of which led to a conflict with the pastor [12]. A memorial stone set up in 1993 at the roadside opposite the church was devoted to him (the sculptor Vilnis Titāns). The servant (ringer's) house is located near the pastorate, the pediment of which is created in the fachwerk construction.

The rectory building together with the church formed the scenic and planning structure of the surrounding area. It can be made sure by examining the situation plan drawn by J. V. Krause in 1821 , where every building, road, forest and the fields, the more distant cemetery are detailed [13]. It can be seen that the present road from Turaida to Ragana directly approached the church, not passing by, as it is now. Walking across the brook, it as if encircles the church and further winds along its present location. The places of peasant farmsteads can be also seen in the plan, such as Puttning,
Wegge, Gailit, Danke. Some of these place names have survived to our days, such as Putnini and Vegi. According to the plan, it can be learned that there was a barn, out-house, horse stable, and cattle-shed in the parsonage. In turn, the building of Kizbele (Kipsal) Manor consisted of the landlord's house, out-house, ice cellar, granary, milk chamber, storehouse, horse stable, cattle-yard, brewery, barn, and garden. It should be noted that the situation layout is not drawn by a land surveyor, so it is rough but a significant cultural and historical reference.

On the situation around the church can be also judged by the land plan of the Krimulda parsonage which in 1862 was drawn by the chivalry auditor J. E. Wruck [14]. Closer to the church, there are four small buildings, behind them - the rectory buildings, one of them - the dwelling house in the present place. Downstream of the personage, at the foothill a school is marked which in the plan of 1821 is not shown. In the lower part, the parsonage land borders with the Gauja, in the lower part on right the boundary goes along a brook behind which the land of Kizbele Manor is located. On the left, the land borders with the fields of Krimulda Manor and higher - with the fields of the Rodi (Rohde) home. 


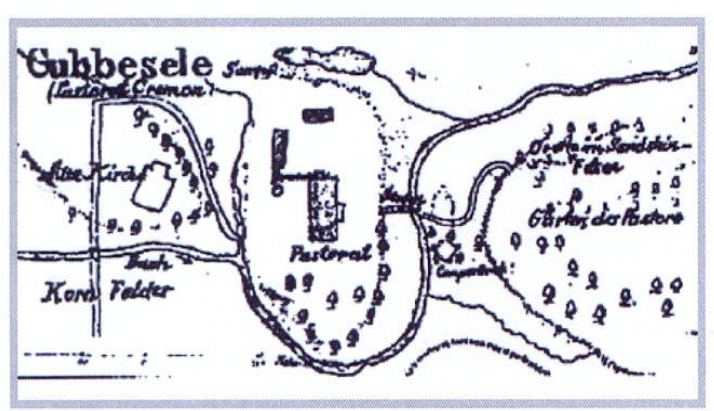

Fig. 6. Kubesele Church and the rectory in the $17^{\text {th }}$ century [Source: htpp://renatar.livejournal.com/254924.html]

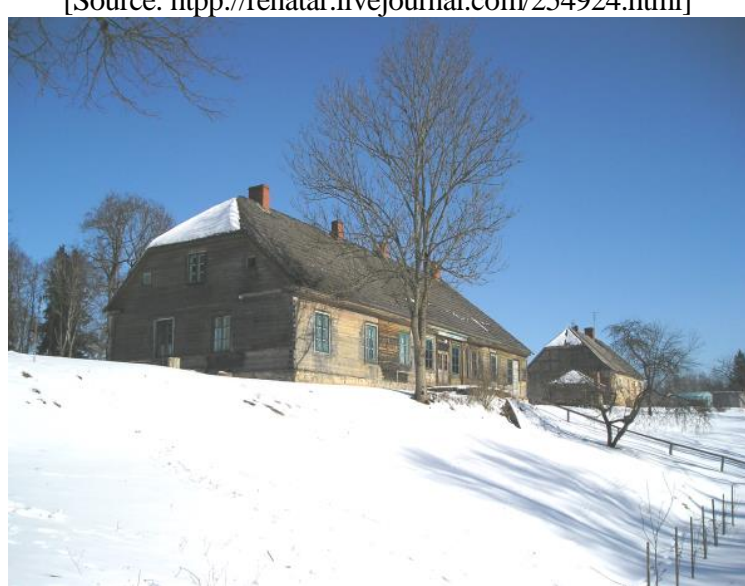

Fig. 7. The Krimulda pastorate [Source: photo by author, 2010]

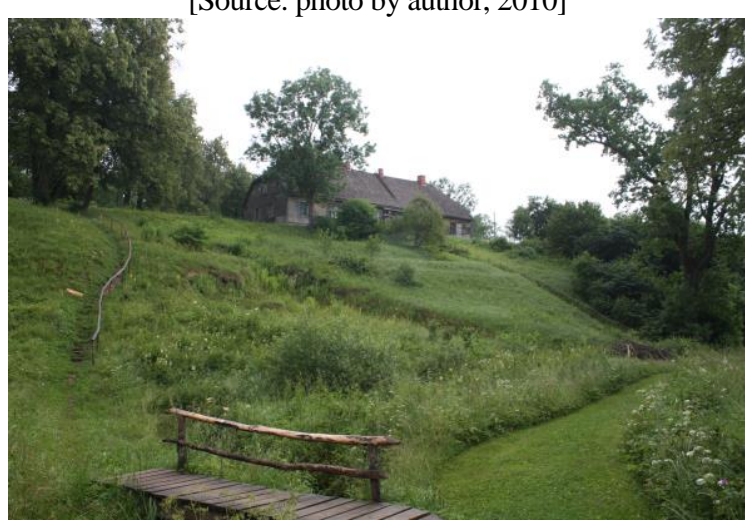

Fig. 8. The Krimulda pastorate

[Source: photo by author, 2016]

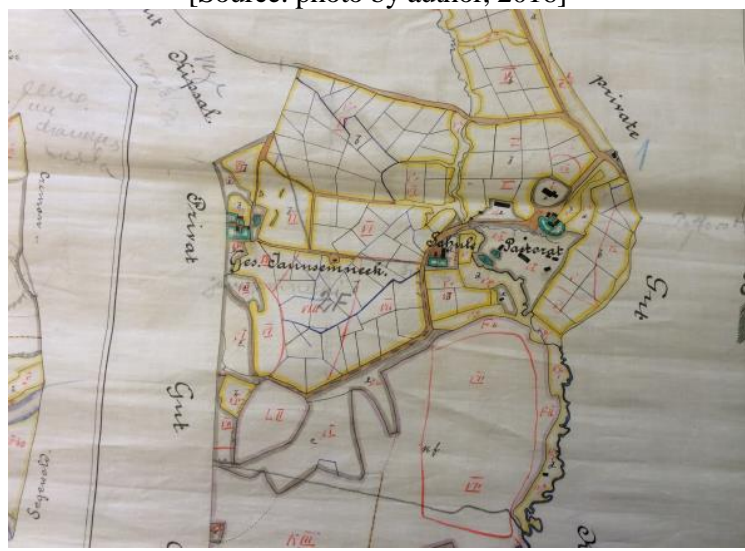

Fig. 9. The land plan of the Krimulda rectory, 1862 [Source: Latvian State Historical Archives, 1679.f., descry. 194., p. 86]

\section{Historical and archaeological evidence}

There is a great diversity of the cultural and historical environment in the immediate vicinity of the church. It includes the historical and archaeological evidence, the landscape, and natural elements. The $3.6 \mathrm{~km}$ long nature trail of Kubesele, created in 2002, starts near the pastorate. The trail, which is a broad and versatile reference leads up to the Gauja and on the way back ends in its starting point. Walking along this trail, we can get acquainted with a series of monuments - Kubesele Castle Mound where in 1991 the early Iron Age items were found during the archaeological research, the commemorative site of Caupo which is marked with a memorial stone on which there is a quote from the Chronicle of Henry (2001, sculptor G. Grundberga). In one section of the road, it is possible to get acquainted with the Barons' cemetery which is located in a special compartment of the old cemetery, created in 1820 . The family tomb of K. von Dahl, the owner of Englārte or Engelhārte (Engelhardshof) Manor was located there, as well as the mortuary of Duke Dunten. During World War I, the latter was devastated and has not survived to our days. In the so-called Landlords' Cemetery, pastors and their relatives were also buried. Today, two gate poles built anew in 1928 instead of the old ones lead to the cemetery which is overgrown. Information about the history of the ancient times is provided by Batarini Mound Cemetery where the so-called Semigallians of the Gauja - the Balt tribal representatives were buried. The burials refer to the time from the $1^{\text {st }}$ millennium before the birth of Christ until the first centuries of our era. They are described in the publications of the end of the 19th century [15].

In the cemetery, on one large mound, a whole family was buried in the course of time, unlike the Liv mound cemeteries where on each one only one person was buried. On the way back, opposite the pastorate on the hill, the cave of Kubesele can be seen, also called Runtinala /the cave of Runtina/. It resembles a big space that is around $6 \mathrm{~m}$ long, but its height is about $3 \mathrm{~m}$. The cave, which is a protected geological site, was formed as a result of continuous movement of the underground waters in the Upper- Devonian sandstone of the Gauja retinue. The above historical, natural, and archaeological evidence enrich the cultural and historical environment of the nearby church, reflect the developments over centuries, formed in the interaction of the human and natural environment. Each of the sites should be specially protected and cared for, their neighborhood or the cultural space should be respected without which the perception of the historical evidence wouldn't be possible. 


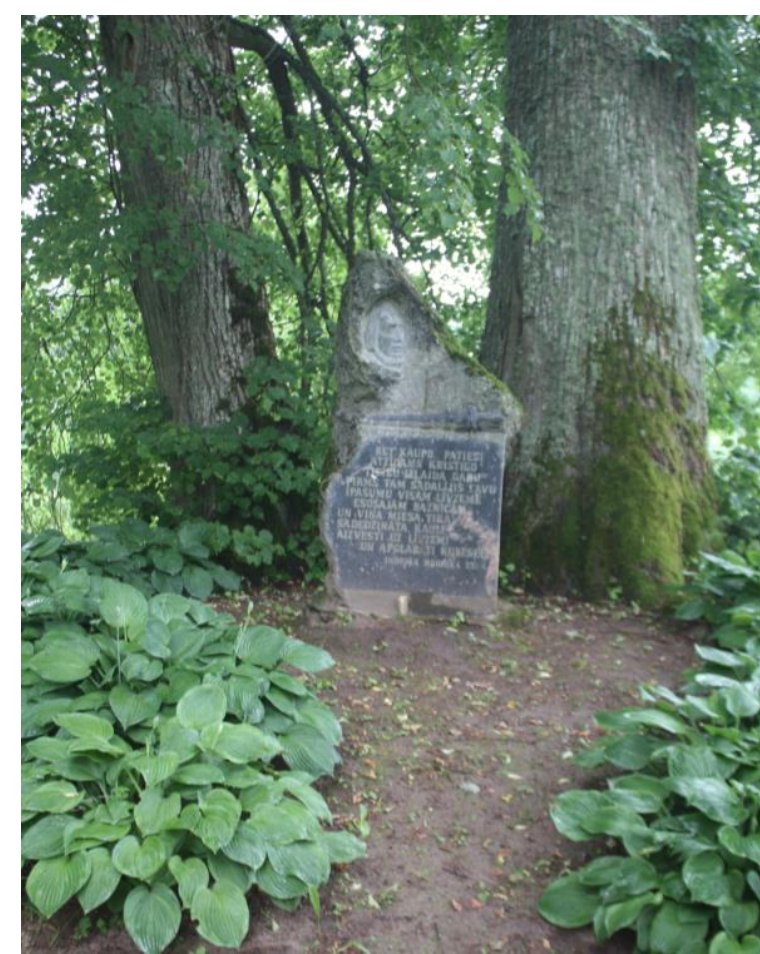

Fig. 10. Monument to Caupo

[Source: photo by author, 2016]

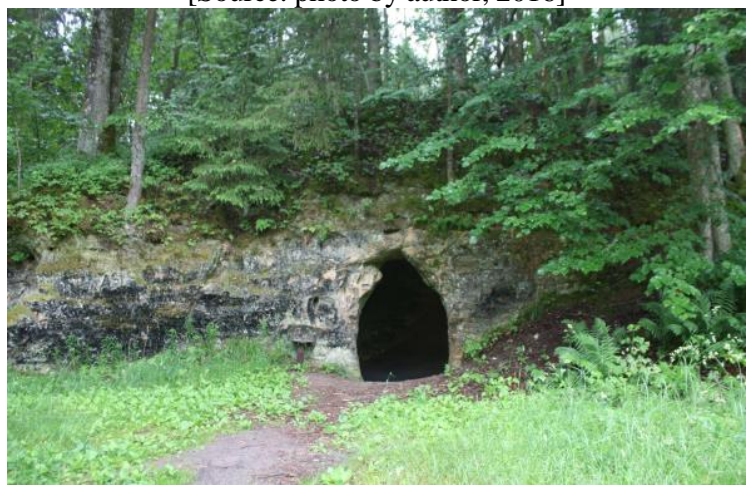

Fig. 11. Cave of Kubesele

[Source: photo by author, 2016]

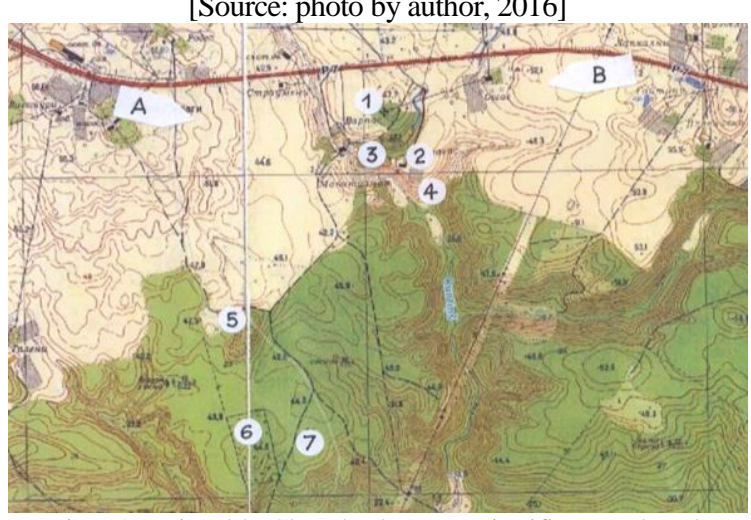

Fig. 12. Krimulda Church: the most significant cultural, historic, and scenic area around it [Source: drawing by author in the topographical plan of 1967]; 1 - church;

2 - rectory; 3 - Kubesele Castle Mound; 4 - Cave of

Kubesele; 5 - Landlords' Cemetery; 6 - cemetery;

7 - archeological site; A, B - the main sight points to the church in the landscape from the road Ragana - Turaida

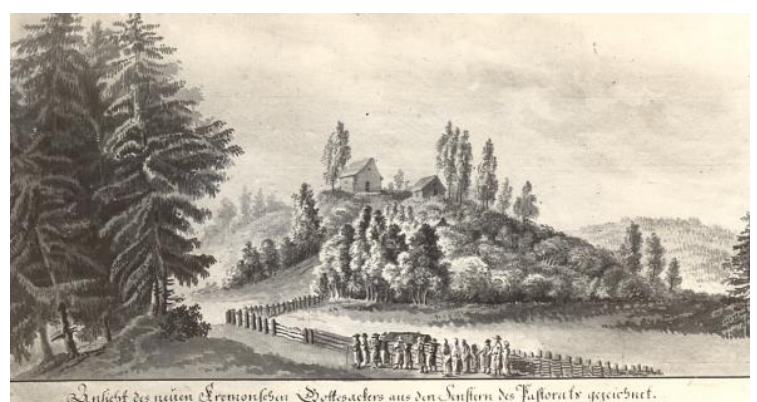

Fig. 13. The new cemetery of Krimulda, the sight from the pastorate [Source: Johann Christoph Brotze. Drawings and descriptions. Riga: Zinātne, 2002, Vol. 3, p. 172, 173]

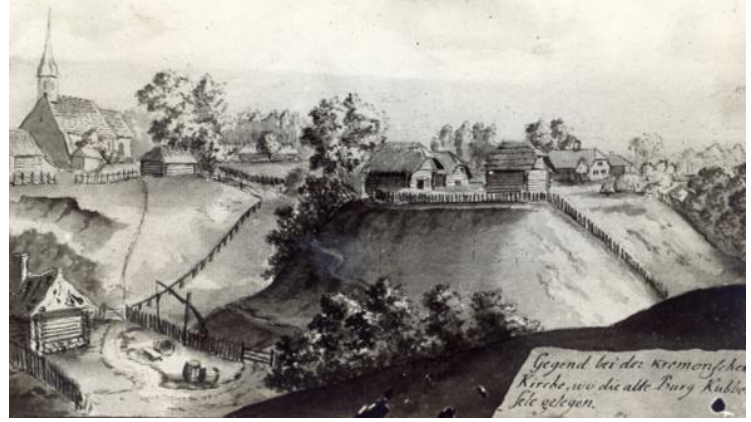

Fig. 14. The rectory and Krimulda Church

[Source: Johann Chistoph Brotze. Drawings and descriptions. Riga: Zinātne, 2002, Vol. 3, p. 166]

\section{The cultural and historical environment} and landscape

The immediate and furthest surroundings of the church are scenically appealing, intact of rashly considered structures and rich in historical evidence. The unique landscape of the church and the parsonage have impressed the coach and the local historian, the later professor of the University of Tartu - Johann Wilhelm Krause (J. E. Krause, 1757-1828), the drawing of whom was placed in the collection of drawings of J. Ch. Brotze [16]. The drawing is named according to the sentimental mood of the time of Romanticism - A sight of the new cemetery of Krimulda, drawn from the windows of the pastorate. At the end of the hill overgrown by trees and shrubs, two ancient mortuaries with a winding countryside road can be seen. The lovely landscape is made gloomy by a funeral procession which moves up the mound. The second drawing by J.V. Krause $A$ sight to Krimulda Cemetery in 1796 is also dedicated to a similar theme. But this time, from the mound we look in the other direction - to the distant church and the rectory. Between the two fragmentarily depicted mortuaries, crosses and two small wooden buildings can be seen. And the third drawing: The neighborhood of Krimulda Church where the ancient Kubesele Castle was located belongs to J. V. Krause. It shows a vast landscape and from the aspect of the cultural and historical information, it provides a lot of interesting revelations. On the castle mound, the parsonage 


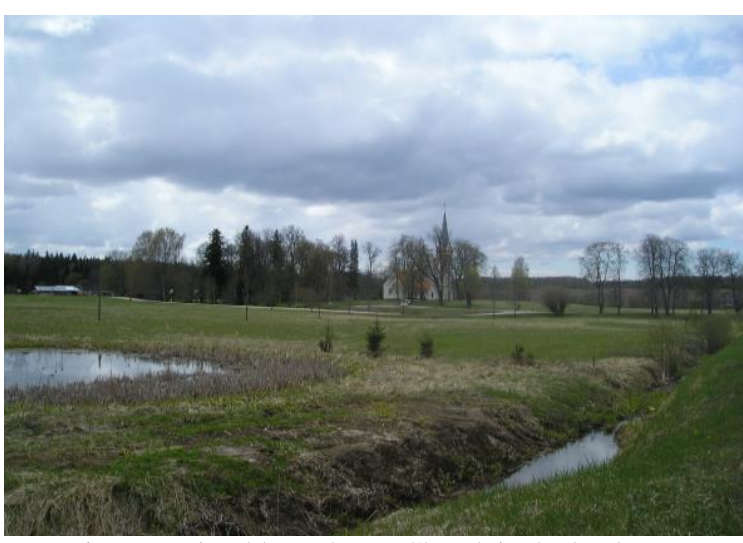

Fig. 15. Krimulda Lutheran Church in the landscape [Source: photo by author, 2017]

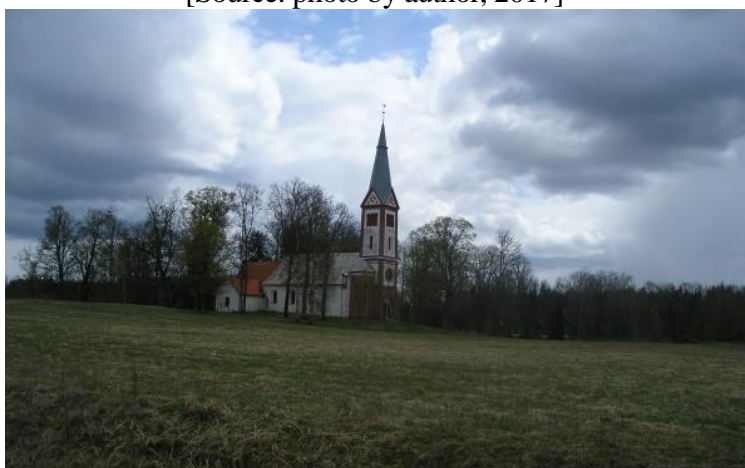

Fig. 16. Krimulda Lutheran Church in the landscape [Source: photo by author, 2017] buildings are located: three log houses in the front are meant for household purposes, behind them to the right there is the pastorate but between the church and the pastorate, there is also a small house. Also, in front of the church and at the foot of the hill buildings are depicted. In the drawing, the hillfort is easily perceptible that cannot be said today - its slopes are more overgrown.

\section{Conclusions}

Already from afar in the landscape, from the road Ragana - Turaida, surrounded by the tree canopy the church tower is still visible a significant vertical dominant. Other elements of the cultural and historical environment, as well as the rest of the building, is visible approaching them and they are of no interest in building a broad landscape of distant points of sight. And it is justified as the church is the main and most important building in the area.

In the course of time, a wide area around the church and the pastorate has retained its attractive landscape and its cultural and historical environment to a large extent - its authenticity. The conservation of this environment is a major challenge for the future.

\section{References}

1. Indriḳa hronika / Ā. Feldhūna tulkojums, Ē. Mugurēviča priekšvārds un komentāri. Rīga: Zinātne, 1993.

2. Caune, A., Ose, I. Latvijas viduslaiku müra baznīcas. 12. gs. beigas - 16. gs. sākums. Rīga: Latvijas vēstures institūta apgāds, 2010, 183. lpp.

3. Broce J.K. Zīmējumi un apraksti. Latvijas mazās pilsētas un lauki. Rīga: Zinātne, 2002, 3. sēj., 169. lpp.

4. Broce J.K. Ibid., 170. lpp.

5. Valsts kultūras pieminekḷu aizsardzības inspekcijas Pieminekḷu dokumentācijas centrs (VKPAI PDC), lieta Krimuldas luterānu baznīca.

6. VKPAI PDC, lieta Krimuldas luterānu baznīca.

7. VKPAI PDC, lieta Krimuldas luterāņu baznīca.

8. Barkāns, E. Dievnams no Kaupo laikiem. Svētdienas rīts, 1996. gada 9. jūnijs.

9. Švalbe, J. Krimuldas dievnama zvanam - 100. Svētdienas rīts, 1995. gada 23. aprīlis.

10. Ermans, J. Krimuldas baznīca un draudze.1205-1930. Rīga: [B.i.], 1930, 5. lpp.

11. Ermans, J., ibid, 18. lpp.

12. Apīnis, A. Neprasot aţ̦auju. Latviešu rokraksta literatūra 18. un 19. gadsimtā. Rīga, 1987, 49.-51. lpp. Faksimilizdevums ar komentāriem: Juris Natanaēls Ramanis. Krusta skolas grāmata. Rīga: Zvaigzne ABC, 1995.

13. Latvijas valsts vēstures arhīvs (LVVA) F. 6828., descr. 6., p. 4430.

14. LVVA F. 1679., descr. 194., p. 86.

15. Jaksch, R. Bericht über Ausgrabungen in Kremon. Sitzungsberichte der Gesellschaft für Geschichte und Altertumskunde zu Riga. Jg. 1895, S. 118.-121.

16. Johans Kristofs Broce. Zīmējumi un apraksti. Latvijas mazās pilsētas un lauki. Rīga: Zinātne, 2002, 3. sēj., 172., 173. lpp.

INFORMATION ABOUT THE AUTHOR:

In 1979, Jānis Zilgalvis graduated from the Faculty of Architecture of the Riga Technical University. In 1990, he defended his doctoral thesis on the subject of the manor architecture of the second half of the $19^{\text {th }}$ century - the start of the $20^{\text {th }}$ century. Since then, he is the Head of the Architecture Department of the State Inspection for Cultural Monument Protection. Since 2012 - a full member of the Latvian Academy of Science. Over 180 scientific and popular scientific publications and 18 books (some coauthored). The main lines of research - the manor architecture and history of culture, sacral architecture, protection of cultural heritage. 
Kopsavilkums. Krimuldas baznīca ir pašreiz vecākā, vēl savam uzdevumam kalpojošā mūra baznīca Latvijā. Baznīcas mūžs ir notikumiem bagāts. Sākotnēji tā saukta par Kubeseles baznīcu un celta 1205.-1206. gadā priestera Alebranda vadībā, drīz pēc līvu valdnieka Kaupo atgriešanās no ceḷojuma uz Vāciju un Romu. Iespējams, ka viņa pīšli apglabāti Krimuldas baznīcas altārdaḷā. Baznīca vairākkārt remontēta un atjaunota (ap 1640. g., 1701., 1865.). Baznīca attēlota J. K. Broces 1794. gada zīmējumā. Jauns baznīcas tornis pabeigts 1905. gadā (arhitekts A. Reinbergs. Baznīca stipri cietusi 1917. un 1918. gadā - sašauts tornis, izsistas logu rūtis, izvazāti gandrīz visi baznīcas iekārtas priekšmeti. 2. Pasaules kara laikā dievnams necieta. 1960. gadā padomju varas spiediena rezultātā baznīca tika slēgta un draudze likvidēta. Sākās posta laiks. Draudze tika atjaunota 1988. gada nogalē. Draudzes priekšnieka K. Dimitera vadībā uzsākās dievnama atdzimšana. 1996. gadā ēka jau bija zem jumta, izbūvētas iekštelpas, sagādāti soli, vēlāk atjaunota kancele. Baznīcas tiešā tuvumā atrodas mācītājmuiža. Mācītājmāja ir savdabīgs koka arhitektūras klasicisma perioda paraugs. Tā pēc draudzes gana Jāṇa Ermana (Ērmaņa) ziṇām varētu būt celta Krimuldas muižas īpašnieka fon Helmersena ierosmē 1775. gadā. Mācītājmuižas apbūve kopā ar baznīcu veidoja plašas apkārtnes ainavisko un plānojuma struktūru. Par to var pārliecināties iepazīstoties ar 1821. gadā J. V. Krauzes zīmēto situācijas plānu, kurā detalizēti norādīta katra ēka, lielcel̦š, mežs un lauki, attālāk esošā kapsēta. Par situāciju ap dievnamu var spriest arī pēc Krimuldas pastorāta zemju plāna, kuru 1862. gadā zīmējis bruṇniecības revizors J. E. Vruks. Lejpus no pastorāta kalna pakājē atzīmēta skola, kas 1821. gada plānā nav uzrādīta.

Liela ir kultūrvēsturiskās vides daudzveidība baznīcas tiešā tuvumā. Tā ietver vēstures un arheologijas liecības, ainavas un dabas elementus. Pie mācītājmājas sākas 3.6 km garā Kubeseles dabas taka, kas izveidota 2002. gadā. Soḷojot pa to varam iepazīties ar virkni pieminekḷiem - Kubeseles pilskalnu, kurā 1991. gada arheoloǵiskās izpētes laikā atrasti agrā dzelzs laikmeta priekšmeti, Kaupo piemiñas vietu, kas iezīmēta ar piemiṇas akmeni. Vienā ceḷa posmā iespējams iepazīties ar baronu kapsētu, kura atrodas īpašā, 1820. gadā izveidotā Vecās kapsētas nodalījumā. Tajā atradās Englārtes jeb Engelhārtes muižas īpašnieka K. fon Dāla dzimtas kapi, kā arī grāfa Duntena kapliča. Par senvēsturi informāciju sniedz Batariṇu uzkalniņkapi, kuros guldīit tā dēvētie Gaujas zemgaḷi - baltu cilšu pārstāvji. Apbedījumi attiecas uz laiku no 1. gadu tūkstoša pirms Kristus dzimšanas līdz mūsu ēras pirmajiem gadsimtiem. Tie aprakstīti jau 19. gs. beigu publikācijās. Kapos vienā palielā uzkalninā laika gaitā guldīta vesela saime, pretēji lībiešu uzkalniṇkapiem, kuros katrā apbedīta tikai viena persona. Atceḷā, iepretim kalnā esošai mācītājmājai redzama Kubeseles ala, kas saukta arī par Runtinalu. Tā atgādina lielu istabu, kuras garums ir ap $6 \mathrm{~m}$, bet augstums ap $3 \mathrm{~m}$. Ala, kas ir aizsargājams ǵeoloǵisks objekts, izveidojusies augšdevona Gaujas svītas smilšakmeņos ilgstošas pazemes ūdeņu pārvietošanās rezultātā. Minētās vēstures, dabas un arheologijas liecības bagātina baznīcas tuvienes kultūrvēsturisko vidi, atspoguḷo gadsimtiem ilgās norises, kas veidojušās cilvēku un dabas vides mijiedarbībā. Ikviens no objektiem ir īpaši saudzējams un kopjams, respektējama ir to apkārtne jeb kultūrtelpa, bez kuras pilnvērtīga vēsturisko liecību uztvere nebūtu iespējama.

Ainaviski pievilcīga, nepārdomātu būvju neskarta un vēstures liecībām bagāta ir baznīcas tuvākā un tālākā apkārtne. Baznīcas un pastorāta apkārtnes neatkārtojamā ainava sajūsminājusi jau minēto J. V. Krauzi, kura zīmējumu savā krājumā ievietojis J. K. Broce. Kokiem un krūmiem apauguša pakalna galā redzamas divas senas kapličas, pie kurām vijas lauku ceḷš. Jauko ainavu padrūmu padara bēru procesija, kas virzas augšup kapu kalnā. Arī otrs J. V. Krauzes zīmējums Skats uz Krimuldas kapsētu 1796. gadā veltīts līdzīgai tematikai. Un arī trešais zīmējums Krimuldas baznīcas apkārtne, kur atradās senā Kubeseles pils pieder J. V. Krauzem. Tajā attēlota plaša ainava un no kultūrvēsturiskās izziņas aspekta tas sniedz daudz interesanta. Pilskalnā izvietotas pastorāta ēkas: priekšpusē trīs guḷbūves domātas saimnieciskām vajadzībām, aiz tām pa labi redzama pati mācītājmāja, bet starp baznīcu un pastorātu atrodas vēl kāda neliela ēciṇa.

Jau iztālēm ainavā, no ceḷa Ragana - Turaida, koku lapotṇu ieskauts joprojām redzams baznīcas tornis nozīmīga vertikāla dominante. Pārējie kultūrvēsturiskās vides elementi, kā pārējā apbūve uztverami tiem tuvojoties un tiem nav nozīmes plašas ainavas veidošanā no tāliem skatu punktiem. Un tas ir pamatoti, jo dievnams bija centrālā un nozīmīgākā būve.

Plaša apkārtne ap baznīcu un mācītājmāju laika gaitā saglabājusi savu ainavisko pievilcību un tās kultūrvēsturiskā vide lielā mērā - autentiskumu. Šīs vides saglabāšana ir nozīmīgs nākotnes uzdevums. 


\title{
Industrial Heritage Landscape of the Lielupe River in Latvia
}

\author{
Daiga Zigmunde, Anna Katlapa, Latvia University of Agriculture
}

\begin{abstract}
The development of production always brings about changes in the landscape, with the emergence of new architectural and technological elements. Due to the changes in technologies and as a result of geopolitical processes, often the existing plants are no longer used or new production facilities built, and thus the post-industrial landscapes emerge. Over time, those once so important production facilities have become the main feature of the identity of a particular site, which is associated not only with visual, but also mental recognisibility of the site through traditions, products manufactured and memories of the local people. Together, this all forms an industrial heritage whose preservation or inclusion in a new modern image, with the emergence of post-industrial landscapes, is becoming an increasingly topical issue. This article deals with the industrial heritage landscape of the Lielupe River in Latvia. Since ancient times the Lielupe River, as one of the largest rivers in Latvia with rich mineral resources, has been an important element in the development of economic activities and production in Latvia. The aim of the research was to identify the causes of the formation of industrial heritage and its impact on the Lielupe cultural landscape. As a result of the research, the main visual and spatial features created by the industrial heritage have been identified in various significant historical periods in Latvia including the present time.
\end{abstract}

Keywords: post-industrial areas, historical analysis of the landscape, impact of industrialization

\section{Introduction}

Industrialization is one of the most significant processes in modern history, which still affects economic, social, geopolitical and landscape changes [4]. Industrial landscapes can be divided according to their physical characteristics - the industrial elements existing in the landscape - into: linear industrial landscapes (hydroelectric power stations and dams, roads and railways), geological industrial landscapes (raw material mining quarries, mines), industrial manufacturing landscapes and urban industrial landscapes (industrial areas on the outskirts of the city) [16]. The landscape is changing, therefore industrial landscapes should be perceived as a process that can also be classified by the degree of industrialization. Mines and quarries are considered to be the primary production landscapes. The discovery of new energy sources leads to the emergence of heavy industry landscapes, which are regarded as the highest point of industrialization. After various stages of industrialization under various circumstances postindustrial and new industrial landscapes can be formed $[11 ; 19 ; 22]$. In the USA and in Western Europe, the issue of post-industrial areas became more topical in the 70's of the 20th century, when, after the so-called "30 golden years", economic stagnation followed leading to the closure of many factories and unemployment [12].

In Eastern Europe, which was still incorporated in the USSR till the end of the 20th century, the issue of post-industrial territories became topical after the collapse of the Soviet Union. The conditions determining the emergence of postindustrial areas were associated with the transition from a planned and state-controlled economy to a free market economy. The economic downturn was followed by a high unemployment rate and various social problems related to that [12]. Latvia (alongside with Moldova, Armenia, Romania and Bulgaria) was one of the countries which was most severely affected by the collapse of the Soviet regime [21]. Landscapes of post-industrial territories in Latvia consist of former industrial territories and engineering infrastructure serving them, derelict military territories, surrounding residential areas as well as the buildings which were started in the Soviet period and left unfinished till this very day [6]. The land privatization process initiated after the restoration of independence has been one of the reasons for the fragmentation of property nowadays, which has had an impact on the management and harmonious inclusion of postindustrial areas in the contemporary landscape. After joining the European Union in 2004, foreign capital began to flow into Latvia more rapidly which also contributed to the revitalization of postindustrial areas.

Post-industrial areas have a significant potential of becoming an industrial heritage as an evidence of ever-so-important economic activities and traditions of a particular region or place, as well as a link between the modern world and the past [5]. The concept of industrial heritage originated in the middle of the 20th century in Great Britain during the Great Depression, when many production facilities were pulled down, thus losing the evidence of the former industrial landscape .

The industrial heritage landscapes are very diverse due to their evolving over time. Many of 


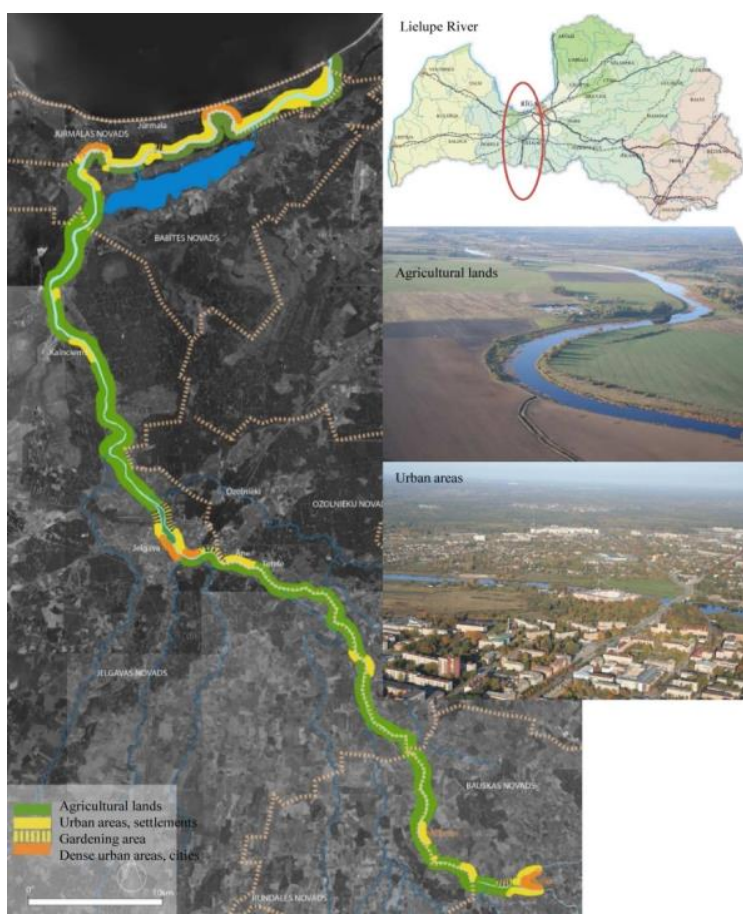

Fig.1. Diverse landscape of the Lielupe River [Source: created by author]

them represent the manufacturing processes, technologies and local economic traditions.

Others are products of global achievements. Some turn into polluted, dangerous, semi-degraded territories due to decline in the local economic activities. Most often historical and currently nonfunctioning manufacturing areas are located close to the historic centers of cities or water courses, in places which presently have a high value of land [2]. Consequently, the inclusion of industrial heritage in the contemporary landscape is a topical subject of urban planning, architecture, landscape architecture and other fields [3].

Visual quality is an important argument for the protection of industrial buildings, but these structures can rarely be considered beautiful. Therefore, the industrial heritage in the cultural landscape is more than just the buildings of an enterprise, it is the combined ability of the facility's history and buildings to narrate a story [8]. If nowadays the industrial heritage of the 19th century and early 20th century finds new applications as tourism objects, residential complexes, etc., then the industrialization of the Soviet period in society is perceived as a transformation of the rural landscape and the disappearance of its traditional form and identity [12].

Nowadays the industrial heritage territories in Latvia have a dual destiny. Due to the lack of management, they naturally collapse and in the long run vegetation takes over the territory, leaving behind ruins. The second development scenario is the transformation of the territories by levelling, preserving them in their existing state, transforming or restoring them.

The Lielupe and Daugava rivers are the largest rivers in Latvia. They have been actively involved in people's economic activities since ancient times, both as transport routes and as a resource. That is the reason why several industrial complexes had been built on the banks of these rivers. The aim of the current research was to identify the causes of the formation of the industrial heritage and its impact on the Lielupe cultural landscape in Latvia.

\section{Material and methods}

Research object

The Lielupe River is the largest river in Zemgale region. Its length reaches $119 \mathrm{~km} \mathrm{[18].}$ Consequently, the cultural landscape of the river is diverse since it flows through different types of landscapes (Fig. 1) - agricultural, forest, marshes, protected areas, industrial and urban landscapes.

The geological structure of the Lielupe region has played a decisive role in the development of production in this region. It is mainly characterized by Quaternary period formations, which form the bulk of the mineral deposits of the Lielupe region clay, dolomite, gypsum, peat, sand and gravel, whereas in the northern part - Devonian sedimentary rocks are found - mainly dolomite, limestone, less clay, gypsum and marlstone. One of the most fertile soil types in Latvia - sod carbonate soils and brown soils - are also located in the Lielupe area, which contribute to the development of intensive agriculture in the southern part of the Lielupe [18].

According to the administrative division, the Lielupe flows through 6 municipalities: Bauska, Rundāle, Ozolnieki, Jelgava, Babīte and Jurmala municipalities, and two cities are located on the banks of the river: Jelgava and Jurmala. Each municipality provides for the improvement of the ecological quality of the Lielupe waters, but only a few mention the improvement of the access to water. The development plans of the territory of Jelgava, Ozolnieki, Bauska and Jurmala local selfgovernments include the creation and expansion of the recreational zone of the Lielupe River bank by organizing the infrastructure for pedestrians and cyclists by installing recreation areas, wharfs, jetties, foot-bridges and other infrastructure amenities that would restore life by and in the water $[1 ; 14 ; 15]$.

Following the regulations of the Lielupe management adopted in 2011, which address only the Lielupe River section of Jurmala and Babite municipalities, the main goals of the Lielupe economic exploitation are promotion of water transport, preservation and enhancement of recreational areas, achieving the ecological quality of water, preservation and increase of fisheries 
potential, ensuring the existence and diversity of the flora and fauna of the adjoining territories, protection of historical and cultural objects of Lielupe and the adjoining territories, alongside with ensuring the accessibility of these territories to the public [18].

\section{Methods}

In order to identify the causes of the formation of the industrial heritage of the Lielupe River cultural landscape and the impact on landscape, a study of this region was carried out in the period from 2015-2017, carrying out a general analysis of the Lielupe cultural landscape and conducting the analysis of particular industrial heritage sites. The development of industrial objects has been viewed in the context of the most important geopolitical and economic events of Latvia, distinguishing the following historical stages: the period of the Russian Empire (1770-1915) and the period of the German Empire (1915-1918), the period of the first Republic of Latvia (1918-1940), World War II and the Soviet period (1940-1990), the period of the restored Republic of Latvia (from 1990 to present day), including the period of membership in the European Union and NATO (from 2004 - present day). For data acquisition and interpretation of results, comparative and descriptive methods of historical and contemporary maps and photographs have been used, as well as analysis of archive materials and scientific literature, field studies, interviews with historians and some local people.

\section{Results and discussion}

The advantageous location, size and geological structure of the Lielupe has been a prerequisite for economic activities in the region. Investigating the changes in industrial landscape on the banks of the Lielupe, it has been established that industrial heritage can be divided into visible industrial heritage, formed by the elements of industrial character, and the indirect industrial heritage formed by the products manufactured, technologies used and traditions observed, as well as elements of social and emotional character - such as human memories and cognition.

The period of the Russian Empire (1770-1915) and the period of the German Empire (1915-1918)

During this period, initially the Lielupe River itself was an active element of the economic activities. In Kurzeme province there were two large navigable rivers - the Daugava and the Lielupe. Sometimes, due to thin ice, the Lielupe was navigable almost all the year round. Many tributaries of the Lielupe River and other smaller rivers of Kurzeme were used for floating logs to Jelgava and Riga (Fig. 2). In 1859, the most dangerous places in the log floating waterways were improved - too

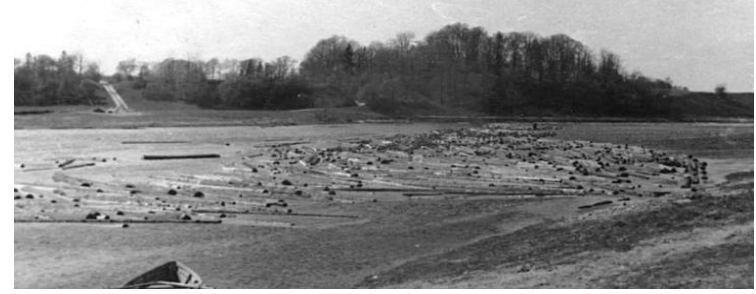

Fig. 2. Floating waterway on the Lielupe River [25] sharp river bends were straightened, rapids were levelled and rocky places were avoided [24]. The natural waterways did not increase the price of manufactured products, water transport had a greater capacity - it could handle larger cargos compared to farmers' carts or sledges. Using river routes, agricultural produce was transported to Riga through Jelgava, whereas the inhabitants of Jelgava were supplied with the necessary goods from Riga.

Before the Agrarian Reform of 1922, manors were the local economic centers, which financed agriculture, brick industry and other economic activities. Along with the construction of the railway lines and roads, road transport won over waterways. At that time, the first railway bridges across the Lielupe were also built - in 1868 a railway line from Riga to Jelgava and in 1877 from Riga to Tukums via Jurmala. In other places, such as Kalnciems, Mezotne, and Jurmala, a ferry was used to transport people across the Lielupe.

In the 1890s, with the development of Riga's industry, active clay mining and kiln building began on the banks of the river Lielupe, which determined the new silhouette of the river with tall chimneys of the kilns [7]. The largest sites with kilns were located in Kalnciems and Ane regions. Due to the geomorphological conditions, the bricks manufactured in Kalnciems were made in a pale yellow tone, while those produced in Ane region had a reddish tint. The bricks were transported by floating them to Riga up the Lielupe River. At the beginning of the 20th century 53 Hoffmann kilns operated in the Lielupe basin, manufacturing 120 million bricks annually [16]. Before World War I the number of Hoffmann kilns increased to 85, manufacturing 230 million bricks a year [9].

The proximity of the river and the deposits of clay and dolomite facilitated not only the creation of production facilities on the right bank of the Lielupe River but also contributed to the development of populated areas which later became cities. Due to the deposits of clay and dolomite, Kalnciems developed into a large building material industry center near the Lielupe waterway, through which at the end of the $19^{\text {th }}$ century the manufactured products were transported to the new construction sites of Riga in barges. Subsequently, the production contributed to the growth of Kalnciems and obtaining the status of the city. 
The proximity of the river and the possibilities of the extraction of dolomite also contributed to the growth of Sloka, when in 1896 one of the oldest and largest paper industry enterprises the Baltic Pulp Mill company in the territory of Latvia was established on the right bank of the river Lielupe alongside with the local dolomite processing cement factory. This company, which had successfully operated for 100 years, including also the period during the first Latvian Republic and in the post-war years until the 1990s, has played a major role in the national economy. Sloka Pulp and Paper Mill together with Ligatne Paper Mill represent the whole industrial sector having a cultural-historical in designing of the factory. The factory supplied Sloka with electricity during its initial operation period.

\section{The period of the first Republic of Latvia} (1918-1940)

After the Agrarian Reform of 1922, the manor lands were confiscated and distributed to landless peasants. During the post-war period, many brick kilns were destroyed and those which were restored faced the shortage of demand and soon stopped working. Agriculture developed rapidly and sugar production was widely spread. In 1926, Jelgava Sugar Factory was founded [7] (Fig. 3). A flax mill was also opened in Jelgava (later it was renamed Flax Factory). Both buildings were destroyed during the war, but after the war they were rebuilt. With the changes in demand and production, the Lielupe Landscape silhouette also changed as the number of the tall chimneys which once dominated the skyline, decreased and larger production sites - building complexes - appeared.

At that time the Lielupe River was still an active element of economic nature. It was used for the transportation of goods and passengers. The increase in the importance of navigation required the construction of harbours and wharfs that were also available to passengers [18]. In 1937, the amount of bricks and lumber transported up and down the river was 0.73 million tons. The number of passangers transported annually was 165,000 [23].

\section{World War II and the Soviet period (1940-1990)}

After World War II, the largest city on the banks of the Lielupe - Jelgava lost $90 \%$ of its historical buildings and was actually built anew using a standard type of housing development typical of the Soviet style. Latvia, being incorporated into the Soviet Union, had to provide production in line with its new territorial status. Consequently, industrial production was rapidly developing and during the Soviet era Jelgava became a highly industrial city. Apart from the existing Sugar Factory and Flax Factory, the Leather Factory, Jelgava Dairy and Machine Building Plant were established. With the development of factories, whose task was to provide

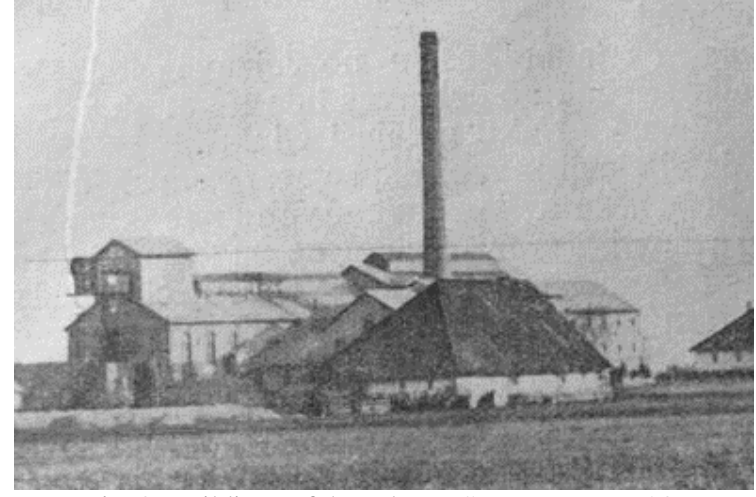

Fig. 3. Buildings of the Jelgava Sugar Factory [23]

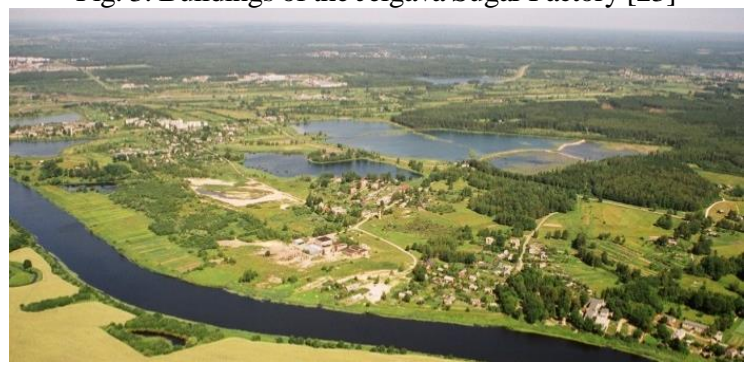

Fig. 4. Clay extraction ponds in Ane and Tetele near the Lielupe River [Source: A. Ziemelniece]

products not only for the inhabitants of Latvia but also for the Soviet Union, Jelgava began to develop along the right bank of the Lielupe. Residential areas for factory workers, who arrived from different places of the Soviet Union, emerged around almost all the large-scale intensive production sites. The transformation of urban landscape of Ane, Tetele, Sloka and Kalnciems is also directly related to the growth of industrial activities. Along the banks of the Lielupe River in the place of the historic Ane Manor and in the vicinity of Tetelmine Manor the production area and clay extraction ponds were formed (Fig. 4). Similarly to Ane, also Kalnciems had turned from a village into a town due to the increase in the production capacity.

Kalnciems Building Materials Complex, established in 1953 and "Spartaks" Plant in Tetele built in 1950, were the largest brick manufacturing plants in Zemgale. They were created by converging earlier existing brickworks [10]. During the Soviet period Sloka experienced a large influx of inhabitants, as a result of which the expansion of the populated areas of the city and the merging with neighbouring populated areas took place.

In 1946, an industrial enterprise - Kalnciems Brick Complex was established as a result of merging of three Kalnciems brick factories "Standarts", "Pūrmali" and "Kaigi". It was an enterprise subordinated to the State Industrial Brick Trust of the Ministry of Building Materials Industry of the Latvian SSR. In the course of its development several additional buildings and workshops were built for its needs. A ferry across the Lielupe River, a complex of apartments and a kindergarten were also built. The main functions of the Kalnciems 
Building Materials Complex were manufacturing of construction bricks, the extraction of splintered lime stone, manufacturing mineral wool and plastic glass [16].

The period of the restored Republic of Latvia (from 1990 till present), including the period of membership in the EU and NATO since 2004

After the collapse of the USSR, the stagnation of the economy in 1991 led to a decline in industrial activity throughout Latvia. There was no longer a need for large-scale factories, thus non-functioning and unmanaged production areas appeared in cities. In search of resources, the government handed over these facilities for privatization, which facilitated the work of self-governments in maintaining the territories, but at the same time loosing control over their historical values. During the period from 1994 to 1997, the largest factories were privatized.

Since 2004, when Latvia joined the European Union and NATO, it became increasingly possible to attract investments for the integration of industrial heritage into the modern landscape. Due to funding from the European Union, under-managed industrial areas were transformed, mainly by completely or partially dismantling old buildings. During the period from 2010 to 2017, many factories along the Lielupe bank were gradually demolished.

Since Jelgava was a typical industrial city, the changes in industrial areas significantly influenced its visual image. The silhouette of the Sugar Factory's production buildings and chimneys disappeared from the bank of the Lielupe river. Instead of those, recreational areas, a promenade and a city beach for residents and guests were made. On the one hand, the city has acquired a quality recreational area, but on the other hand, it has lost its historical identity. The name of the railway station "Sugar Factory" is the only reminder of the former brilliance of the factory. Jelgava Flax Factory also ceased to exist and was partially demolished in 2016 due to the dangers of the construction's design caused by the illegal removal of metal elements during long-term non-management of the building.

Jelgava Building Materials Complex is in a partially functioning condition. From 1991-1995, the State Jelgava Building Materials Complex manufactured fibrolite multilayer insulating boards and it was the only manufacturer of this type of product in the Baltics [13]. Since 2015, two industrial sectors have been represented there - a plastic recycling plant and a facility manufacturing concrete parts, occupying half of the buildings in the territory. An unobstructed barrier of reinforced concrete slabs separates the plant's territory from the other functional zones. A concrete production tower forms the vertical dominant of the territory and is also visible from the railway station "Sugar Factory" and Jelgava bypass road. Since the period of closure of the industrial areas, the local residents have experienced a decline in the quality of life. Prior to this, the factory - and the state - took care of the improvement and maintenance of local areas, but when the status changed from state to private property, people felt dissatisfied and confused as to who should take responsibility. When the factories closed down, many people lost their jobs and moved to other cities, resulting in the decline in the total population and demographic rates.

The production facilities of Ane and Tetele have survived, and they still function but their capacity in manufacturing clay bricks, tiles and other fired building materials, as well as the scope of wholesaling timber, construction materials and plumbing equipment have decreased. The visual image of Kalnciems and the halt in its development are also related to the cessation of production. The operation of Kalnciems Brick Factoty stopped in 1994 and it was divided into 3 companies. Later during the Latvian financial crisis, these production facilities were suspended [16] and gradually from 2011 to 2017 Kalnciems Building Materials Complex was partially demolished (Fig. 5 and 6). It has dramatically changed the landscape of the Lielupe riparian landscape. Clay mining quarries have become naturalized as a recreational place for the local residents. Kalnciems industrial heritage is represented by a view over the former clay ponds and those abandoned production sites which have not yet been demolished - especially chimneys and the water tower.

The Pulp and Paper Mill in Sloka has been partially demolished leaving behind only cultural historical buildings. In 2009, Sloka Pulp and Paper Mill's cultural-historical brick buildings and chimneys were recognized as cultural-historical monuments of which several buildings were preserved: the factory's office building, auxiliary building, the gate, residential building, the first paper mill building, the 19th-20th century chimney, the wood chipping building and the chimney built in 1963. According to the amendments to the territorial plan of Jurmala (functional zoning), the territory is marked as a production type territorry. The chimneys of the Pulp and Paper Mill are already visible from the Jurmala bypass road bridge and the silhouette of the factory is in contrast with the adjacent meadows, forming visual dominance. The most valuable vistas in the territory embrace the Lielupe meadows on the opposite bank. In other parts of the territory there are half-delapidated buildings, ruins of buildings and piles of trash. 


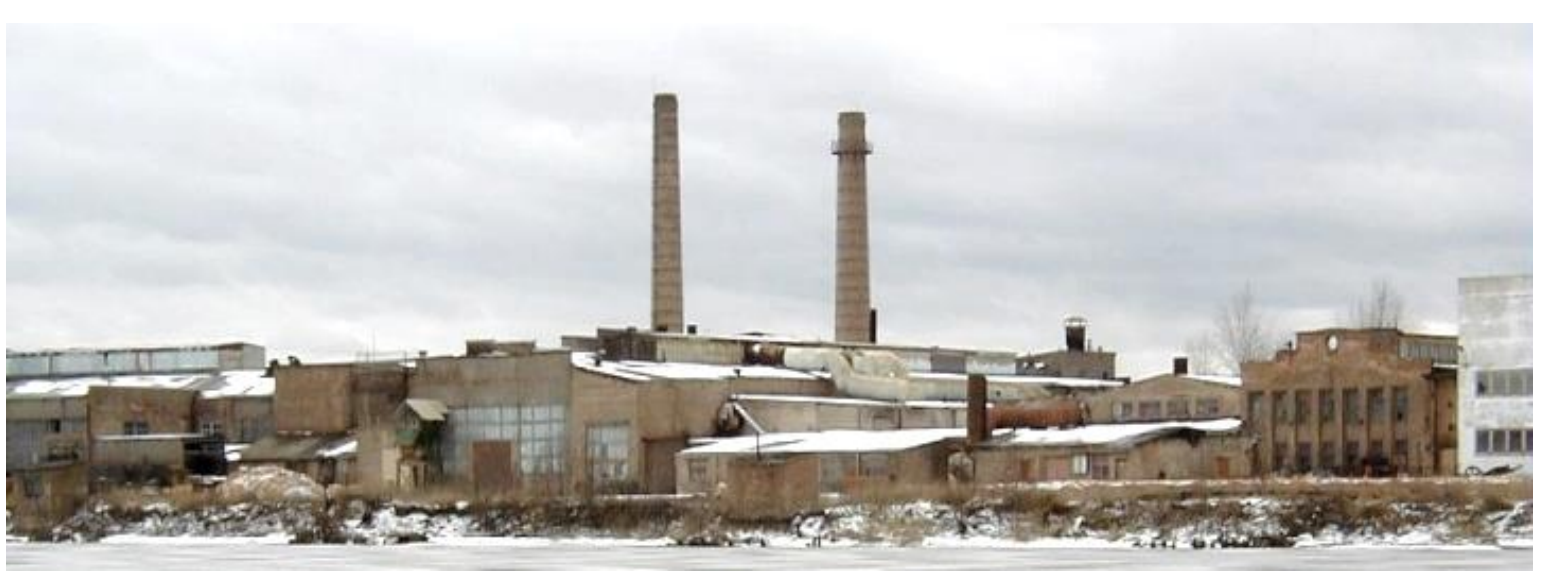

Fig. 5. Kalnciems Building Materials Complex, end of the $20^{\text {th }}$ century [Source: http://mapio.net/pic/p-9562461/]

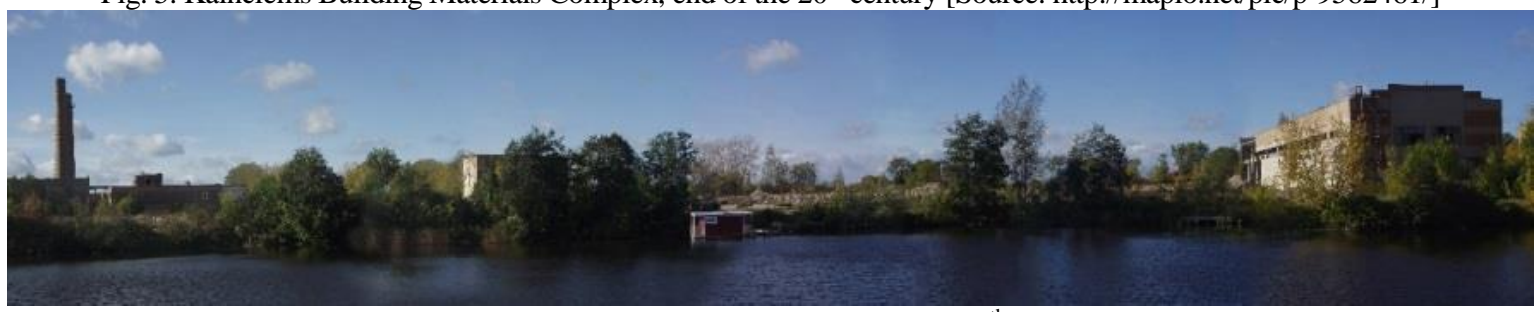

Fig. 6. Kalnciems Building Materials Complex, beginning of the $21^{\text {th }}$ century [Source: A. Katlapa]

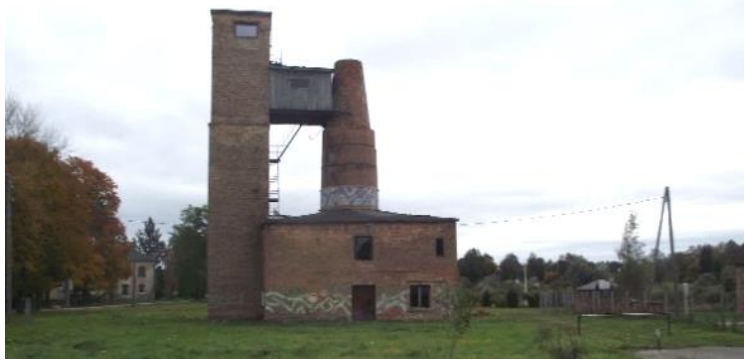

Fig. 7. Brick firing kiln in village Ceplis [Source: A. Katlapa]

The industrial heritage from the 19th century has been preserved in places subject to smaller anthropological load and slower development mainly rural areas. Manor houses, which were significant economic and production centers in the 19 th century, are nowadays being converted into recreational or residential areas. For example, guest houses have been opened in Mezotne and Mazmezotne Manor houses. Bornsminde Manor house was privatized in 2000, and in 2003 it was intended to open a guest house there with 14 rooms, but due to financial problems the plan was not implemented and the estate is in a state of ruins. A similar situation is observed regarding Kaucminde Manor. Its reconstruction requires significant financial investments, but the municipality cannot provide such funds, especially if no proper use of these buildings can be found. In most cases these conditions result in the situation that the fate of cultural monuments depends primarily on the perceptions, desires and opportunities of each owner. The local residents believe that the manor houses are ruinous and dangerous. They also think that not only the owners but also the local people are guilty of ruining the estates by plundering the materials of the manor houses - timber, windows, doors, etc.

Today, the brick buildings of Sloka Pulp and Paper Mill, carcasses of the mills in Sloka and Emburga, as well as the remains of the brick firing kiln in village Ceplis are important witnesses of the 19th century. Taking into account the fact that the brick kilns were usually demolished just after they had been used, it is important to record and document the future development and conservation of the brick kilns. At present, the Kiln is the only historical industrial building that has survived to the present day in Ceplis of Mezotne rural territory, being the only brick kiln that can be viewed. However, it does not have the status of a cultural heritage monument. The kiln building has been converted into a studio and is a children's leisure center (Fig. 7).

The influence of industrial territories on the Lielupe cultural landscape in the context of the most significant historical periods in Latvia is shown in Fig. 8. Gunita Osīte, a researcher at Latvia University of Agriculture and manager of Jelgava City Development and Urban Planning Department, in her study on the possibilities of returning historical production areas to the city's landscape, concluded that much attention should be paid to the architectural and functional rehabilitation of these zones, since they dramatically affect the image and identity of the city, as well as the public's perception, and they are an important part of the urban planning structure [20]. 


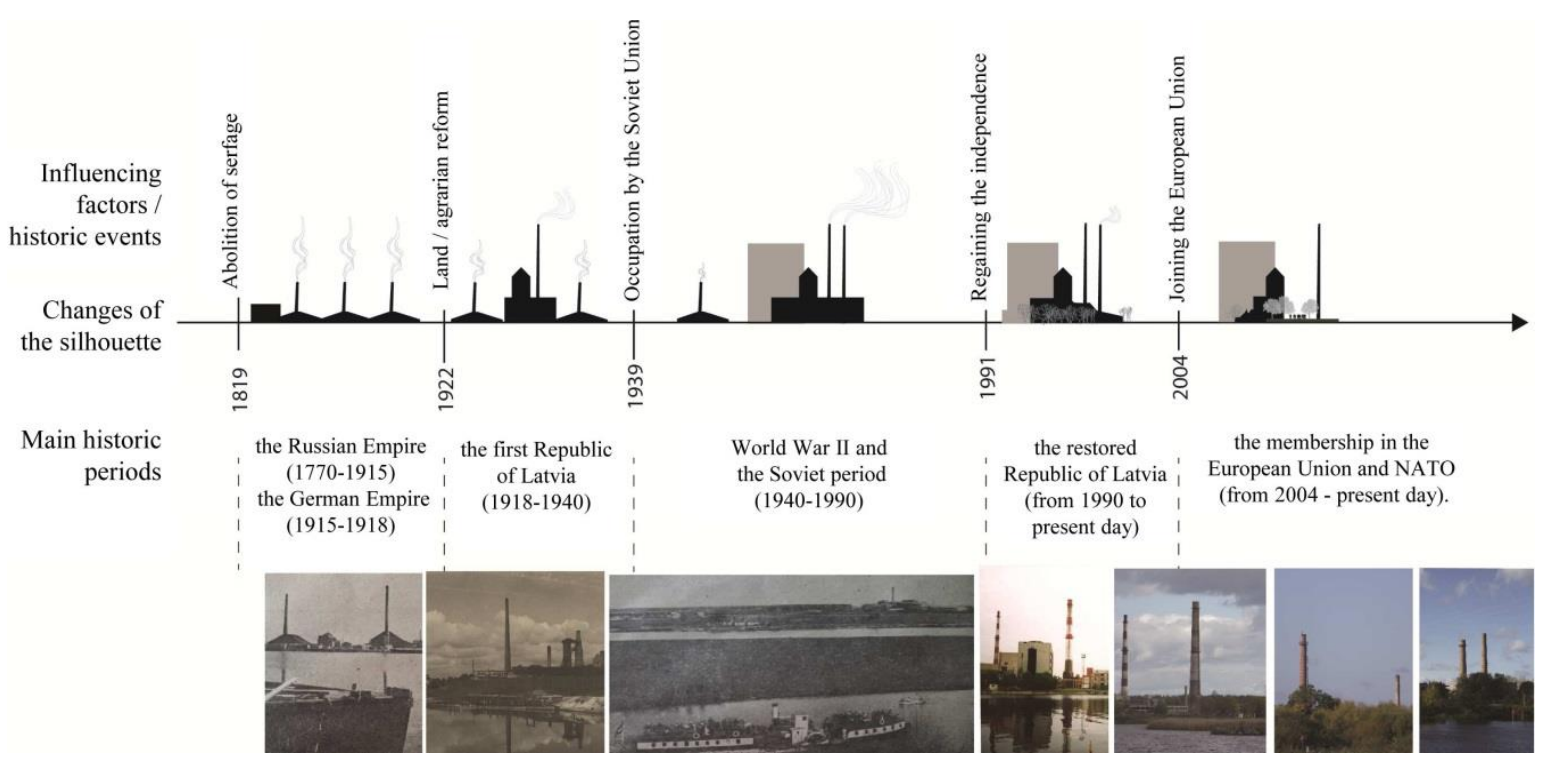

Fig. 8. The influence of industrial territories on the Lielupe cultural landscape in the context of the most significant historical periods in Latvia [Source: created by author]

\section{Conclusions}

The development of industrial heritage in the Lielupe cultural landscape has been promoted by the river itself as an important economic resource and a transport and communication corridor alongside with the geological values of the Lielupe territory clay, dolomite and other mineral deposits. The available resources have influenced the development of specific production facilities whose buildings and technical elements have determined the visual image, structure and silhouette of the Lielupe cultural landscape since the 19th century.

However, apart from the favourable economic environment and available resources, geopolitical processes have played a significant role in the formation or disappearance of the industrial heritage in the Lielupe cultural landscape. Initially, it was the economic activities of the manor houses and the silhouette created by the first chimneys of clay kilns. Later, with changing technologies and production intensity, larger industrial complexes appeared. Then due to the economic downturn and changes, the silhouettes of once so powerful enterprises disappeared or ruins appeared in the landscape, but as soon as investments were attracted, the industrial territories were demolished or revitalized and included in the contemporary landscape.

Occasionally overlayering of historically significant processes is observed bringing about changes in the visual image of landscape, but nevertheless, keeping alive the memories of historical events. For example, the territories of manors, which, under the influence of various land reforms and political decisions, have been fragmented, lost or transformed. Langervalde Manor, for example, had been transformed into Jelgava Building Materials Factory.

Today, most industrial heritage sites have been privatized, and they are beyond the direct influence of municipalities, therefore owners often choose not to take into account the industrial heritage and carry out complete demolition of old buildings. The main task of preserving the industrial heritage is to preserve the narrative of the production process preserving its historical identity. Territories closer to the city center are more likely to become a socially significant object of interest.

\section{References}

1. Bauskas novada teritorijas plānojums 2012.-2023.gadam (Bauska Municipality Territorial Planning for 2012-2023) [online 1.07.2017.]. http://www.bauska.lv/lv/pasvaldiba/publiskie-dokumenti/teritorijas-planojums

2. Bellakova, E. Analysis of Industrial Architectural Heritage - Iron and Steel Plants as a Development Potential. Procedia Engineering, 2016, No. 161, pp.1926-1931.

3. Blagojevic, M.R., Tufegdzic, A. The new technology era requirements and sustainable approach to industrial heritage renewal. Energy and Buildings, 2015, No. 115, pp. 148-153.

4. Chan, E.C. What roles for ruins? Meaning and narrative of industrial ruins in contemporary parks. Journal of Landscape Architecture, 2009, No. 4 (2), pp.20-31.

5. Clark, J. Adaptive Reuse of Industrial heritage: Opportunities \& Challenges. Melbourne: Heritage Council of Victoria, 2013, $20 \mathrm{p}$.

6. Degradēto teritoriju izpēte Rīgas pilsētāa (Research of degraded areas in Riga City) [online 1.07.2017.]. http://www.sus.lv/sites/default/files/media/faili/08_degradetas_teritorijas_riga.pdf

7. Dravnieks, F. Lielupe. Rīga: Valters un Rapa, 1932.

8. Edensor, T. Industrial ruins: spaces, aesthetics, and materiality. New York: Berg Publishers, 2005, 200 p. 
9. Grosvalds, I. Latvijas dzīlyu bagātības. Rīga: Zinātne, 1970, 170 lpp.

10. Grosvalds, I., Alksnis, U. Būvkeramikas izstrādājumu ražošana Latvijā (1944-1990). The Production of Building Ceramics in Latvia (1944-1990). The Humanities and Social Science. History of Science and Higher Education: Scientific Journal of Riga Technical University, 2010, No.16, p. 38-41.

11. Hilpert, U. Regionalisation of Globalised Innovation. Locations for advanced industrial development and disparities in participation. London: Routledge, 2003, $272 \mathrm{p}$

12. Industrial heritage around the Baltice Sea. M. Nisser, I. Isacson, A. Lundgren, A. Cinis (eds.) Uppsala:Uppsala universitet, 2012, 264p.

13. Jelgavas būvmateriālu kombināta vēsturiskā liecība (Historical Evidence of the Jelgava Building Materials Complex), Archive Foundation No.575, n.d.

14. Jelgavas novada teritorijas plānojums 2012.-2023.gadam (Jelgava Municipality Territorial Planning for 2012-2023) [online 1.07.2017.]. http://www.jelgavasnovads.lv/lv/pasvaldiba/publiskie-dokumenti/jelgavas-novada-teritorijasplanojums-2011-2023-gadam/

15. Jūrmalas pilsētas teritorijas plānojuma grozijumi 2016.-. gadam. Teritorijas izmantošanas un apbūves noteikumi (Jurmala City Territorial Planning for 2016-. Regulations for the use and building of the territory) [online 1.07.2017.]. https://www.jurmala.lv/docs/j16/x/TIAN.pdf

16. Kalnciema būvmateriālu kombināta vēsturiskā liecība (Historical Evidence of the Kalnciems Building Materials Complex), Archive Foundation No.662, n.d.

17. Lichi, A. Industrial landscape. Lucrari Stiintifice, Seria-B-LV-2011, 2011, p. 694-698.

18. Lielupes baseins (Basin of Lielupe River) [online 1.07.2017.]. http://www.upes.lv/informacija/lielupes-baseins

19. Mah, A. Industrial Ruination, Community and Place: Landscape and Legacies of Urban Decline. Toronto: University of Toronto Press, 2012, 240 p.

20. Osīte, G. Rūpniecisko zonu arhitektoniski ainaviskā rehabilitācija Jelgavā (Landscape rehabilitation of industrial areas in Jelgava City). Master Thesis. Jelgava: Latvijas Lauksaimniecības universitāte, 2004, 90 lpp.

21. Philipov, D. Dorbritz, J. Demographic consequences of economic transition in countries of central and eastern Europe. Population studies, No. 39, 2004, 205 p.

22. Pike, A. De-Industralization. In: International Encyclopedia of Human geography. Amsterdam: Elsevier Science, 2009, pp. 51-59.

23. Tomašūns, A. Mana Jelgava. Jelgava: Zemgales Reǵiona kompetenču attīstības centrs, 2015, 224 lpp.

24. $\bar{U}$ dens ceļi Kurzemes gubernas laikā (1795-1915) (Waterways during the period of Kurzeme province (1795-1915)). Resource of the Gederts Eliass Museuma [online 1.07.2017.]. http://jvmm.lv/Las\%C4\%ABtava/jelgavas-vesturesannales/udens-celi-kurzemes-gubernas-laika-17951915/

25. Zudusī Latvija. Resource of historic photographies [online 1.07.2017.]. http://www.zudusilatvija.lv/

INFORMATION ABOUT AUTHORS:

Daiga Zigmunde, Dr.arch., Professor in Latvia University of Agriculture, specialized in fields: landscape ecology, human perception of landscape, landscape study. E-mail: daiga.zigmunde@1lu.lv

Anna Katlapa, Mg.arch., landscape architect. Field of research: industrial heritage landscapes. E-mail: anna.katlapa@gmail.com

Kopsavilkums. Lielupe un Daugava ir lielākās Latvijas upes, kuras jau kopš seniem laikiem ir aktīvi tikušas iesaistîtas cilvēku saimnieciskajās aktivitātēs - gan kā transporta ceḷi, gan kā resurss. Tāpēc tieši šo upju krastos ir veidojušies vairāki ražošanas kompleksi. Raksts apskata industriālā mantojumu Lielupes kultūrainavu Latvijā. Lielupe kā viena no lielākajām Latvijas upēm ar bagātīgiem derīgo izrakteṇu resursiem jau no seniem laikiem ir bijusi nozīmīgs elements saimnieciskās darbības un ražošanas attīstībai Latvijā. Pētījuma mērḳis ir identificēt industriālā mantojuma veidošanās cēloṇus un ietekmi uz Lielupes kultūrainavu. Izpētes rezultātā noteiktas galvenās industriālā mantojuma veidotās vizuālās un telpiskās iezīmes dažādos Latvijai nozīmīgos vēsturiskajos periodos un mūsdienās.

Industriālā mantojuma veidošanos Lielupes kultūrainavā ir veicinājusi pati upe kā nozīmīgs saimniecisks resurss un transportēšanas un saziņas koridors, un Lielupes teritorijas ǵeologiiskās vērtības - māla, dolomīta un citu derīgo izrakteņu atradnes. Tieši pieejamie resursi ir ietekmējuši specifisku ražotņu veidošanos, kuru ēkas un tehniskie elementi jau kopš 19. gs. ir noteikuši Lielupes kultūrainavas vizuālo tēlu, struktūru un siluetu.

Tomēr bez saimnieciskajai darbībai labvēlīgās vides un pieejamiem resursiem, ǵeopolitiskajiem procesiem ir bijusi būtiska loma industriālā mantojuma izveidē vai izzušanā Lielupes kultūrainavā. Sākotnēji muižu saimnieciskā darbība, pirmo māla cepḷu augsto dūmeṇu veidotais siluets. Vēlāk, mainoties tehnolog̣ijām un ražošanas intensitātei, parādās lielāki industriālie kompleksi. Savukārt ekonomiskās lejupslīdes un pārmaiṇu rezultātā ainavā pazūd kādreiz tik varenie ražotṇu silueti vai parādās drupas, bet ienākot investīcijām - industriālās teritorijas tiek nojauktas vai arī revitalizētas un ieklautas mūsdienu ainavā.

Mūsdienās lielākā daḷa industriālā mantojuma teritorijas ir privatizētas un atrodas ārpus pašvaldību tiešās ietekmes, līdz ar to īpašnieki bieži vien izvēlas neṇemt vērā industriālo mantojumu un veikt pilnīgu vecās apbūves nojaukšanu. Galvenais uzdevums industriālā mantojuma saglabāšanā ir nodrošināt ražošanas procesu stāsta saglabāšanu - savas vēsturiskās identitātes saglabāšana. Teritorijām, kas atrodas tuvāk pilsētas centram ir lielāka iespēja kḷūt par sabiedriski nozīmīgu objektu. 